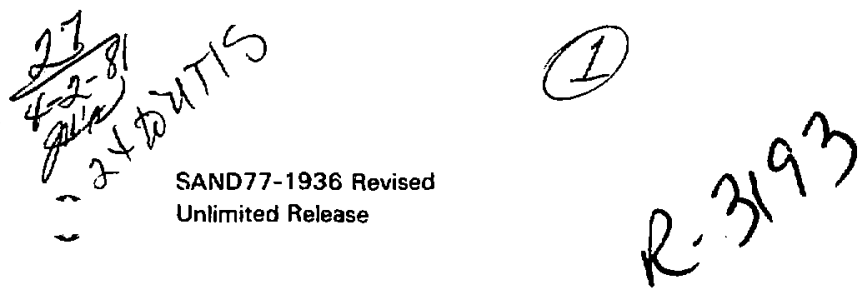

\title{
Nuclear Material Operations Manual
}


SAND77-19.36 Revised

Unl imited Release

Printed February 1981

NUCl.EAR MATERIAL OPERATIONS MANIJAL

\author{
Richard P. Tyler \\ Safeguards and Technical Security Rivision 3434 \\ Sand ia National Laboratories
}

Albuquerque, NM 87185

\begin{abstract}
This manual is intended to provide a concise and comprehensive documentation of the operating procedures currently practiced at Sand ia National Laboratories with regard to the management, control, and accountability of nuclear materials. The manual is divided into chapters which are devoted to the separate functions performed in nuclear material operations-management, control, accountability, and safeguards, and the final two clapters comprise a document which is also issued separately to provide a summary of the information and operating procedures relevant to custodians and users of radioactive and nuclear materials. The manual also contains samples of the forms utilized in carrying out nuclear material activities. To enhance the clarity of presentation, operating procedures are presented in the form of "playscripts" in which the responsible organizations and necessary actions are clearly delineated in a chronological fashion from the initiation of a cransaction to its completion.
\end{abstract}
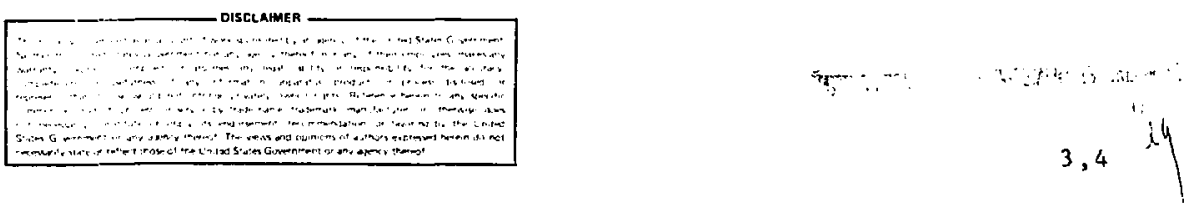


\section{CONTENTS}

CHAPTER I. INTRODUCTION

$\underline{\text { Page }}$

$1-1$

CHAPTER II, DEFINITIONS

$2-1$

CHAPTER III. GENERAL INFORHATION 3-1

1. Activities 3-1

2. Operational Structure 3-5

2.1 Overall Organization 3-5

2.2 Nuclear Materials Management Organizations 3-5

3. Responsibilities 3-11

3.1 Nuclear Materials Management Organizations 3-11

3.2 Support Groups $3-12$

CHAPTER IV. MANAGEMENT 4-1

1. Responsibilities 4-1

2. Authorization of MBA's 4-5

2.1 Procedures for the Authorization of On-Site
MBA's

2.2 Procedures for the Authorization of Off-Site
MBA's

3. Review of Program and Budget Proposals 4-8

4. Analytical Studies; Risks, Contingencies, Options 4-9

5. Forecasts $4-10$

5.1 Procedures for the Development of Annual
Forecasts

6. Procurement and Concract Activities 4-12

6.1 Procedures for the Requisition of Radioactive
and Nuclear Materials
$4-12$

6.2 Ordering Nuclear Materials $\quad 4-14$

6.3 Procurement Status Program 4-16 
7. Scrap and Excess Materials; Expenditures

7.1 Procedures for Obtaining DOE/ALO Authorization for Scheduled Nuclear Material Expenditures by Fiscal Year

8. Utilization of Material

$4-18$

$4-20$

9. Management Reports

9.1 External Reports

4-21

9.2 Internal Computer-Generated Reports

1. Responsibilities 5-1

2. Job Descriptions 5-6

3. Control Flowcharts 5-9

4. Receipts 5-11

4.1 Procedures for the Receipt of Radioactive and Nuc lear Materials

5. Internal Transfers

5.1 Procedures for the Transfer of Nuclear Materials

6. Storage

6. 1 Procedures for the Storage of Nuclear Materials Initially Received

6.2 Procedures for the Storage of Nuciear Materials Requested and Approved by Using Organizations

$5-2 n$

$5-23$

7. Shipments

7.1 Procedures for the Shipment of Radioactive and Nuclear Materials (except to Rocky Flats or the DOD)

7. 2 Procedures for the Shipment of Radioactive and Nuclear Materials to Rocky Flats

7.3 Procedures for the Shipment of Nuclear Materials to the DOD

7.4 Procedures for the Shipment of Scrap and Excess Materials for Recovery 
8. Scrar.

8.1 Procedures for Machining Operations $5-34$

8.2 Procedures tor the Burial of Scrap 9-36

9. $\because A$ as: ement Control Programs 5-39

9.1 Certification of llnconidininated Balances 5-39

9.? Calibration and Weighing Procedures in Tech Area $V$ 5-39

9.3 Procedures for the Calibration and lise of

10. Seal Accountability and Control 5-43

10.1 Procedures for Controlling, Issuing, and Applying Seals

$5-43$

11. Exporting Accountable Nuclear Marerials $5-46$

1.1. Procedures for Exporting $5-4 h$

12. Slu...1 Procedures $5-49$

12.1 Procedures for the Verifiration of the Presence
of SNM in Tech Area $V$

12.2 Procedures for the Performance of Emergency
Inventories of SNM in Tech Area V

CHAPTER VI. ACCOUNTABILITY 6-1

1. Responsibilities $6-1$

2. Jub Discription 6-5

3. Arrountability Records $h-7$

¿. Procedures for Maintaining: the Computer Corporate
l.edger

P. Procedures for the l'pdat. if Sandia's Computer
Recorit; 3.3 Procedures for the lipdate of the NMMSs Computer
Recoras

4. Receipts 6-12 A.l Procedures for the Accu:nnt ability of Nuclear
Material Receipts 
4.2 Procedures for the Accountability of Nucloar Material Constructive Receipts

$6-18$

5. Shipments

$6-19$

5.1 Pracedures for the Accountability of Nucloar Material Shipments

$6-20$

6. Adjustments to Inventory

$6-25$

6.l Procedures for the Accountability of Nuiloar Material Fexpenditures

$6-25$

5.2 Procedures for the sconunt ability of vulen vaterial Disposals

$6-27$

3. 3 Procedures for the Accountebility of Vutiar Matirial Decays

$5-29$

6.4 Prucedures for the Accountability of Internal Transactions

$5-3 n$

7. Internal Audit Program

ケ- 32

7.1 Procedures for thr Performance of Internal ind its

$6-32$

Q. Invintory

$6-34$

8.1 Procedures for the Performance of Inveniorics

$5-34$

8.2 Supplamental Inventory Instructions

$6-38$

9. DOF. sudits

$5-39$

9.1 Safeguards and Srcurity Survey

$6-39$

9.2 Nuclor Materials Managemer Appraisal

$4-40$

10. Accountability Reports

$6-4$ I

10.1 Fxternal Reports

$5-41$

10.2 Internal Computer-Generated Repurts

$6-43$

11. Computer Listings

$6-4.6$

$7-1$

CHAPTER VII. SAFEGUARDS

$7-1$

1. General Requirements 


\section{CONTENTS $($ cont $)$}

2. Storage of SNM

3. SNM in Use

4. On-Site Shipments of SNM

7-7

5. Loss of Accountable Nuclear Material

$7-8$

6. Special Procedures for Access to the Manzano Storage Structures

$7-9$

6.l Procedures for Access to the Manzano Storage St ructures During Operational Hours

$7-10$

$7-10$

6.2 Procerures for Access to the Manzano storage Struclures During Nonoperational Hours

$7-13$

CHAPTER VIII. COMPENDIUM OF RELEVANT NUCIEAR YATERIALS MANACFMENT AND CONTROL FORMS

$8-1$

q-1

$7-3$

1. Definitions

2. Responsibilit ies of l'sers and custodians

$9-9$

3. Program and Budget Proposals

$9-11$

4. Forecasting for Selected Nuclear Materials, Boron-1n, and Kryaton-85

$9-12$

5. Procurement of Nuclear Materials

$9-15$

6. Authorization for Cuslodian Delegation

$9-1^{7}$

7. Receipt of Materials

$9-19$

Q. Safequards

9-3?

9. Records of Accountaible Yaterials

$9-27$

10. Inventory of Accountable Materials

$9-29$

11. Expenditure, Jodification, and toss of Materials; Disposition of Scrap

$9-71$

12. Assembly/Disassembly and Mnvement

$9-35$

13. Stornef of Materials

$9-36$

14. Internal rransfer and Movement of Matorials

$a-1.9$

15. Shipment of Materials

$9-43$

16. Exporting Accountable Nuclear Yaterials
$9-47$ 


\section{CuNTENTS (ront)}

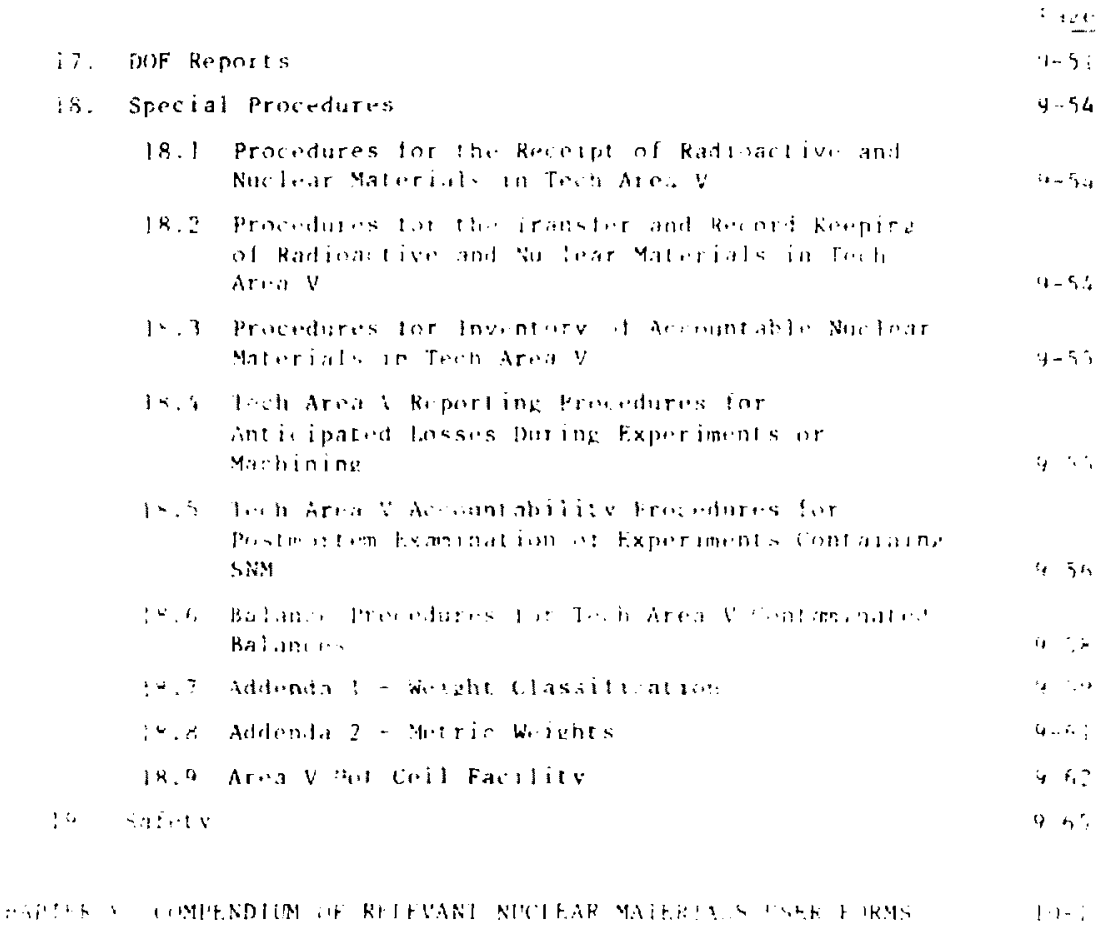




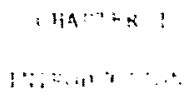

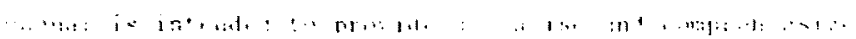

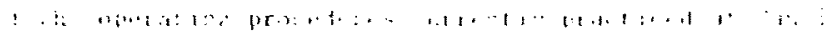

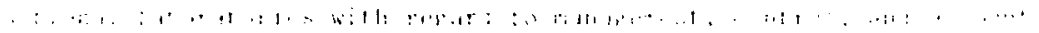

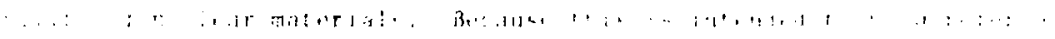

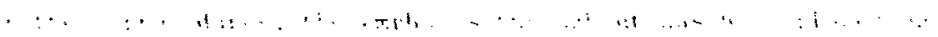

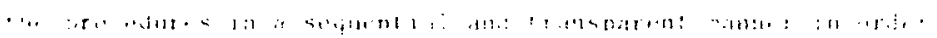

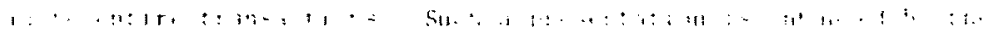

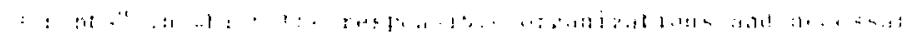

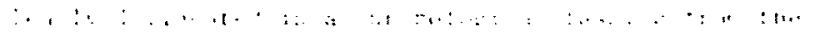

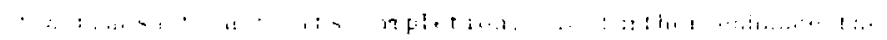

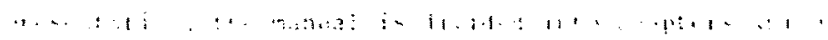

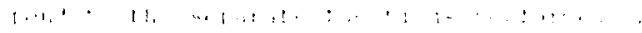

$\therefore \ldots$

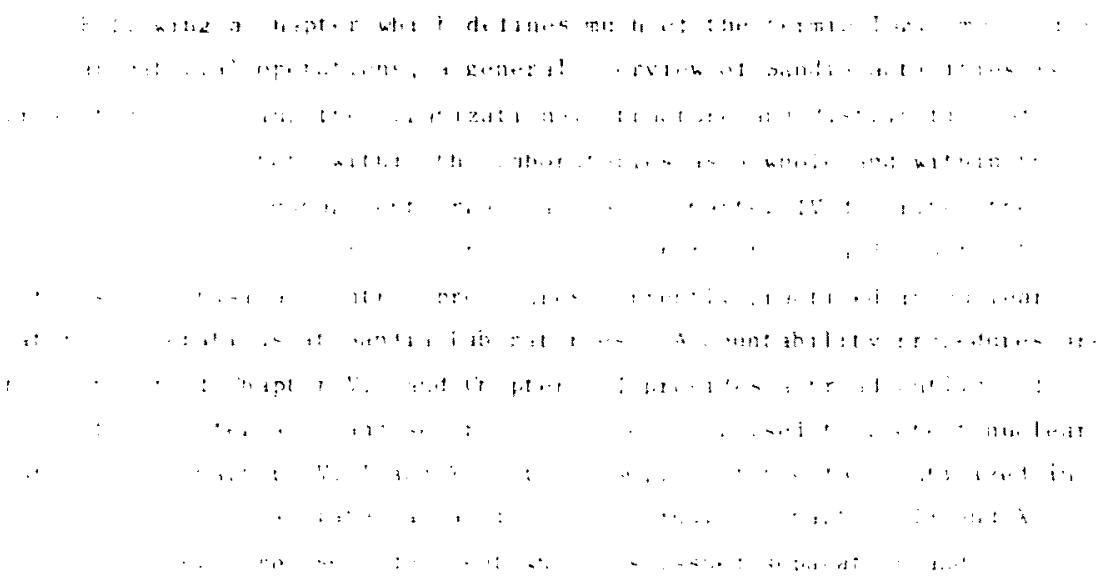


distributed to all custodians, alternate custodians, and using organizations and which provides a concise and comprehensive summary of the information and operating procedures relevant to custodians and users cf radioactive and nuclear materials.

Numerous DOE, Federal, and Sandia documeris supplement the information contained in this manual, and no attempt has been made to duplicate procedures or requirements which are fully documented isewhere. Among the dociments which should be considered as adjuncts to this manul are the following:

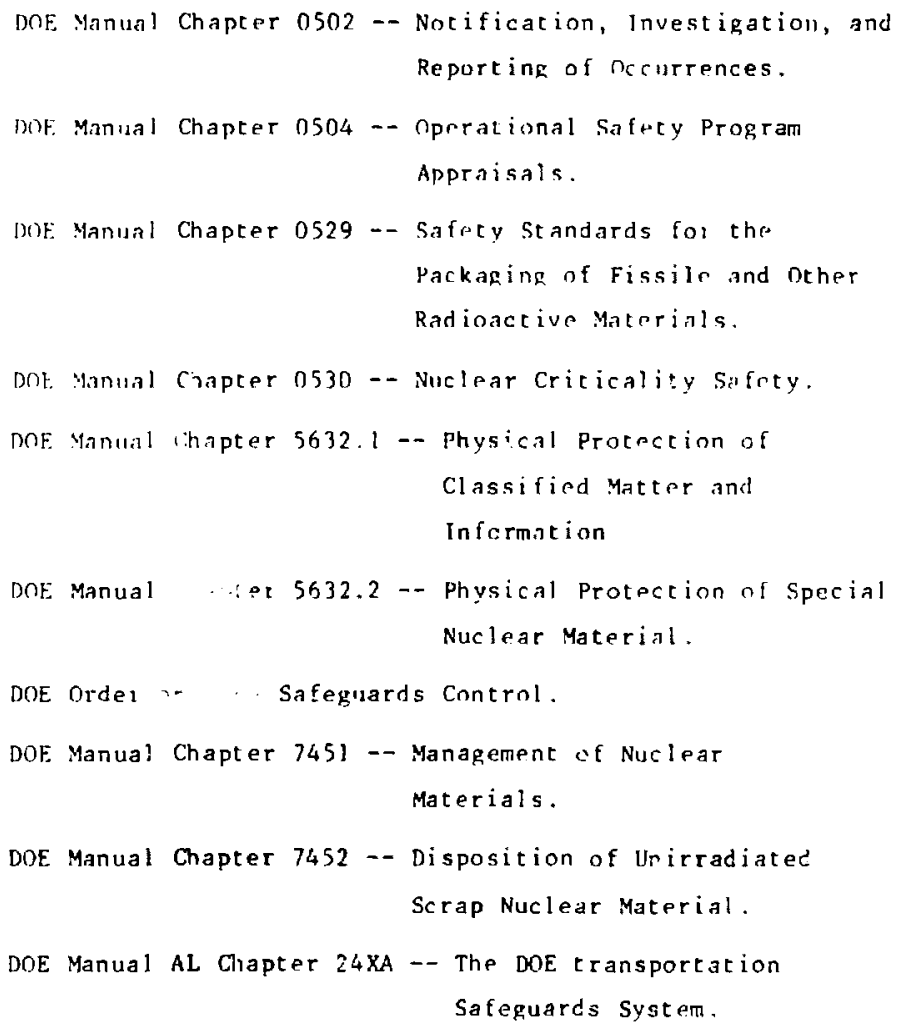




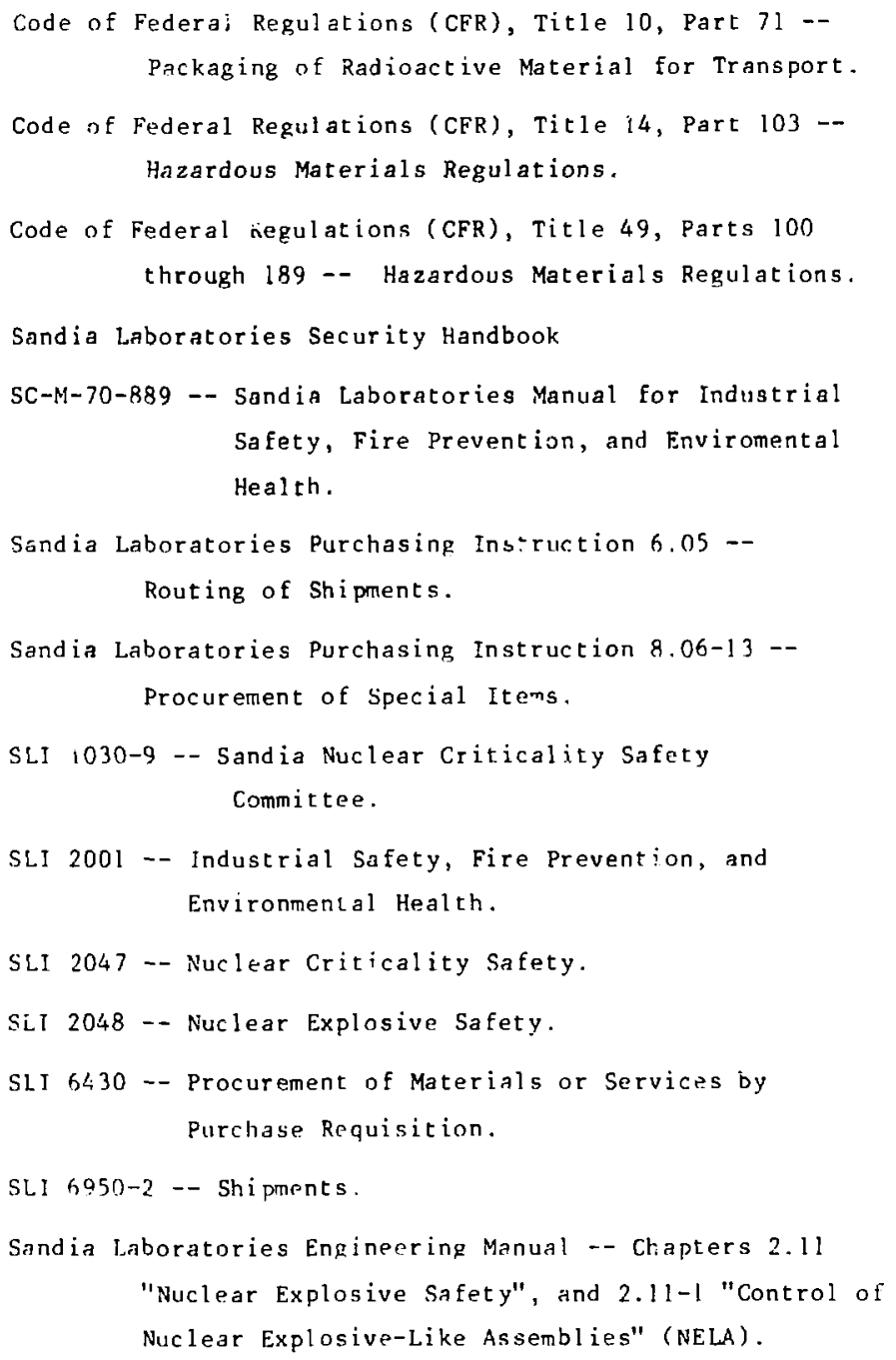

The procedures contained in this manual are current as of the date of publication, and the manual will be updated as procedures are revised. In addition, at least once a year the entire manual will be reviewed and updated to ensure the accuracy of all of the procedures contained therein. 
CHAPTER II

DFFI:ITIONS

Anomeate malerials - a collective term which inclueles accumu-

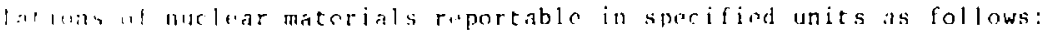

\begin{tabular}{|c|c|c|c|}
\hline N11:1, Malterial & Reporting lnit & $\begin{array}{l}\text { R.portahl. } \\
\text { 2ty. }\end{array}$ & 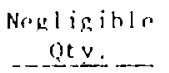 \\
\hline 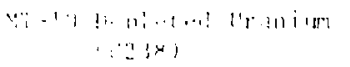 & 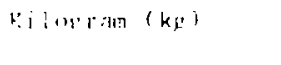 & $>010112$ & $<51 h:$ \\
\hline 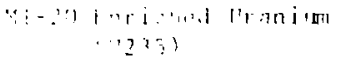 & (A) dm $(\mathrm{g})$ & $>0.5 \%$ & $<0.5 \mathrm{~g}$ \\
\hline$\because:-, 1,111,1,0,542$ & lir am & $>01.50$ & $<0.5 \mathrm{~s}$ \\
\hline 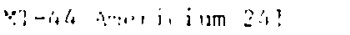 & Gir am & $>0.5 \%$ & $<0.5 y$ \\
\hline 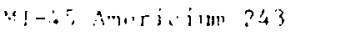 & rir an: & $>0.5 \Omega$ & $<0.5 \%$ \\
\hline 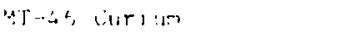 & Crr am & $>0.50$ & $<0.5 \%$ \\
\hline$\because \because-\therefore 7$ Birk+lium ?:4 & Micragris ( $\mathrm{mi}$; & $>0.5 \mathrm{my}$ & $<0.5 .79$ \\
\hline $47-f_{4}$ C Cali fornium $25 ?$ & Yicrogram & $>0.5 \mathrm{mg}$ & $<0.5 \mathrm{mg}$ \\
\hline 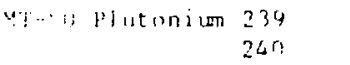 & GT $а m_{\mathrm{i}}$ & $>0.5 \mathrm{~g}$ & $<0.5 p$ \\
\hline 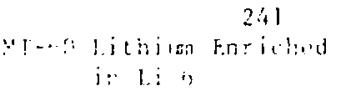 & kilout:aाז & $>5 n ! 1 \quad 2$ & $<500 \mathrm{E}$ \\
\hline Y']-:1 l'raniilin $(1: 33)$ & Gram & $>0, q_{1}$ & $<0.5 \varepsilon$ \\
\hline MT-xl lis:rma! Itraniln? & Kilogran & $>500$ & $<500)$ \\
\hline 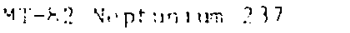 & Cir:ami & $>10.5 \quad$ & 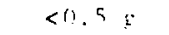 \\
\hline 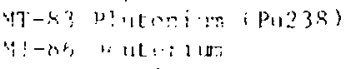 & $\begin{array}{l}\text { Srim to Tenthe } \\
\text { Filngtam en T.Mnchs }\end{array}$ & $\begin{array}{l}>0.05 \\
>\operatorname{inn} g\end{array}$ & $\begin{array}{l}<0.05 \% \\
<100\end{array}$ \\
\hline 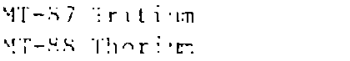 & $\begin{array}{l}\text { Gram to Hundrriltist } \\
\text { ki!ngram }\end{array}$ & $\begin{array}{l}>0.005: 9 \\
>500\end{array}$ & $\begin{array}{l}<0.005 \text { i } \\
<500 \%\end{array}$ \\
\hline
\end{tabular}

Apparent loss - Pbe inability to locato physically or otherwiso account for any miluar matorials, irrespotive of the size, dimensions, "r wight of the mat.rials.

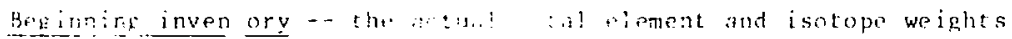

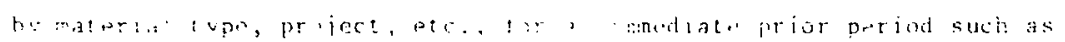

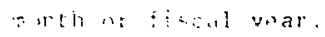


Category $T$ quantities of special nuclear materials -- plutonium - 2 $\mathrm{kg}$ or more; $233 \mathrm{u}-2 \mathrm{~kg}$ or more; $235 \mathrm{u}$ (contained in uraniun enriched to $20 \%$ or more) - $5 \mathrm{~kg}$ or more. If plutonium or $233 \mathrm{u}$ is combined with $235_{\mathrm{u}}$, the amounts of Pu or ${ }^{233} \mathrm{u}$ shall be multiplied by 2.5 to arrive at the limits shown,

Category II quantities of special nuclear materials - plutonium 400 to $1999 \mathrm{~g} ;{ }^{233} \mathrm{u}-400$ to $1999 \mathrm{z}_{\mathrm{i}}{ }^{235} \mathrm{u}$ (contained in uranium enriched to $20 \%$ or more) - 1000 to $4999 \mathrm{~g}$. if plutunium or $233 \mathrm{u}$ is combined with $235 \mathrm{u}$, the amounts of Pu or $233_{\mathrm{u}}$ shall be multiplied by 2.5 to arrive at the 1 imits shown.

Category IJI-A quantities of special nuclear materials -- plutonium 220 to $399 \mathrm{~g} ; 233 \mathrm{u}-220$ to $339 \mathrm{~g} ; 235_{\mathrm{s}}$ (contained in uranium enriched

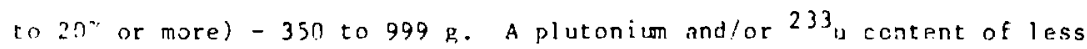
than 400 g may be combined with $235 \mathrm{u}$ when the total content is less than Inח $\varepsilon$.

Category III-B quantities of special nuclear materials - plutonium 1 to $219 \mathrm{~g} ; 233_{\mathrm{u}}-1$ to $219 \mathrm{~g} ;{ }^{235} \mathrm{u}$ (contained in uranium enriched to $20 \%$ or more) - 1 to $349 \mathrm{~g} ;{ }^{235} \mathrm{u}$ (contained in uranium enriched to less than $20 \%$ - all quantities above $0.99 \mathrm{~g}$.

Continuous surveillance -- the observation of Category I and Category I I secial nuclear materials or their container when in use or in open storage by at least two authorized, Q-cleared persons who may be doing other work but who can give an alam in time to prevent the unauchorized removal of the special nuclear materials.

Criticality-safe - a condition in which fissionable materials are stored in a configuration which prevents an accidental nuclear criticality. 
Custodianialternace custodian - the persons designated by using vrianizatians (and approved by their Director) to control and account for .11 ruliar materials within a material balance area.

Nalt number - a mumerica? designation assigned by an ordering field $\therefore t i \therefore l a$ an authorization for the withdrawal of nuclear materials, or trankes troun ane progeram to another.

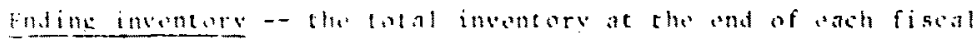

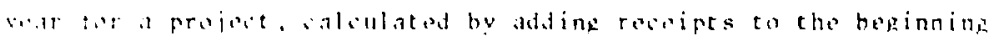

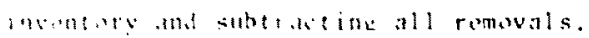

Extess matorials -- nut loar materials for whish there are no plamed

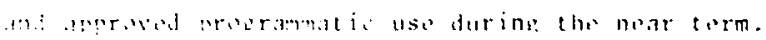

Yissilir materials - a colloctive term which includes uranium-233,

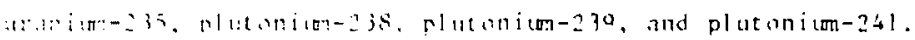

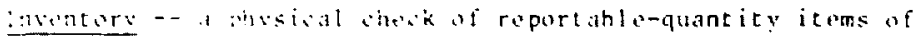

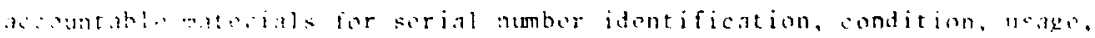
and $\therefore \cdots 11, \cdots$

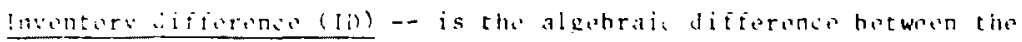
atwiser matorial bovk inventory (BI) and a physical invontory (PI): i.p. $11=31-P 1$.

lreodiated returns -- materials which, in their existing form, have bata subiection torator irradiation.

lasal shipments -- transfers or novements of materials between Sandia Laboratories tethnical areas andior kirtland AFB.

Loss -- the inability to locate physicaliy or account for any accountati: quatity I nular material. 
Material access area (MAA) - an area containing Category I quantitios of special nuclear materials, specifically dofined by physical hatrings and located within a protected areo, with arcess rostrictod to sperifiod anthorized personmel anly.

Material balance area (MRA) - a numetical designation assigned by tho Sategards and Technical Stcurity Divisjon to an organization, location, or spenified area which is authorized to receive nuclear materials.

Nomid operational iosstes (NOL) -- 1 loss of material detrrminad by mincuriment or by estimation the bisis of measurement, which, whether in thes form of solids, liquids, or gasiss, has bern discordid.

Include material:

3. Distarded to settling pond: sewirs, iribs, stacks, or burial grounds;

b. Discarded in contaminated items such as equipmint, laundry, and shoe covers. Quantities of NOI. must be tetermined by measurement or by astiuate m the hasis of measurement.

Nuclear materials -- a collective term which includus source materials, special nuclear materiaj, ard those otior materials arsignated by the Assistant Secretary of Drfensc. Programs for the Dot. All physical and .herllical horms (including scrap) of the following materials are presently inclind.el: 


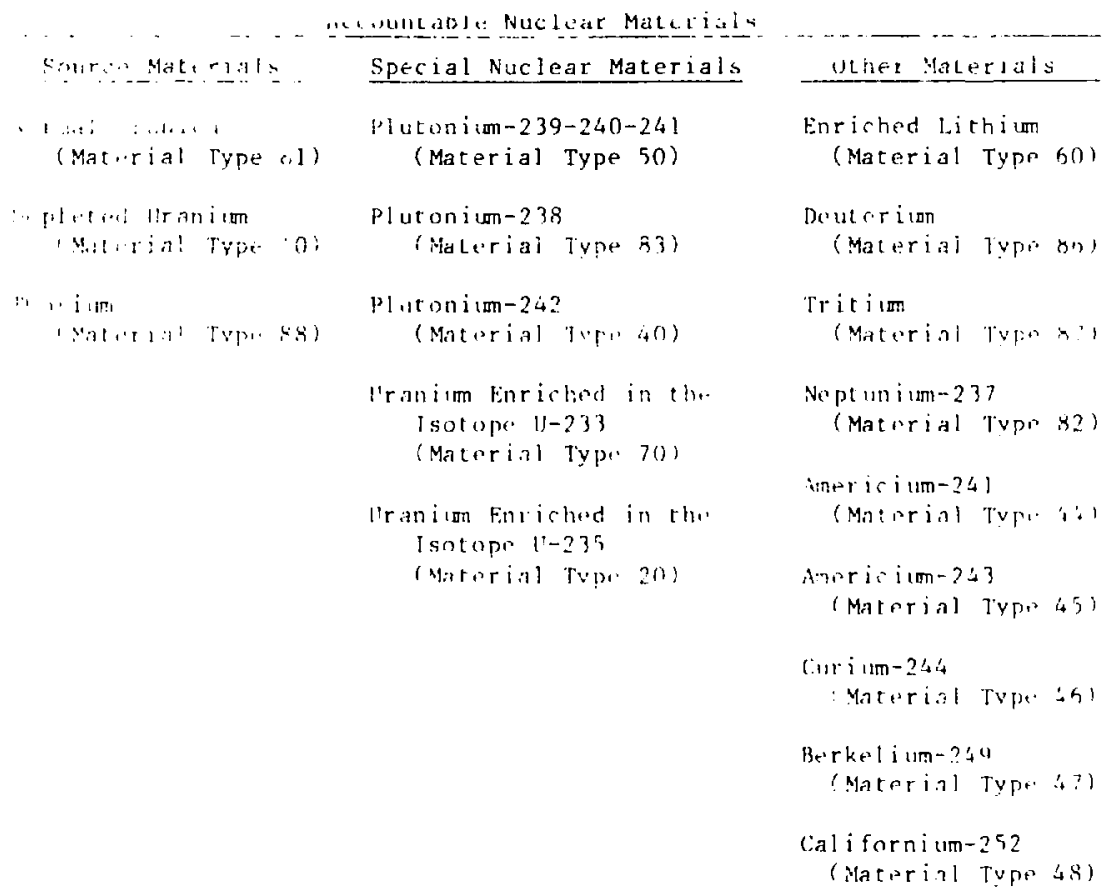

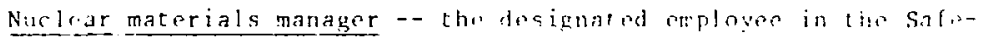
giards and Technical Securjty Division who is resprnsible for developing and directing the overall nuclear materials management propram at Sandia

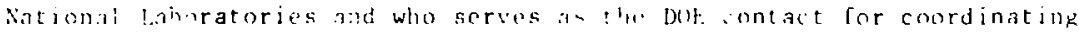

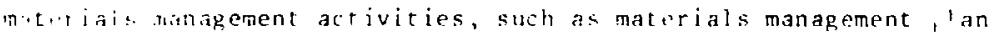
properallai contractor materials mana nent appraisals, forecastin; ot

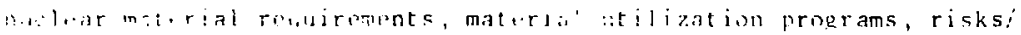
contingares plans fer mpet ine inventory arerts, reduction of budget expenditures through materials manapenent, excess and scrap disposition, and analytical studios.

Nucleat materials representaivi - the designated employee in thi"

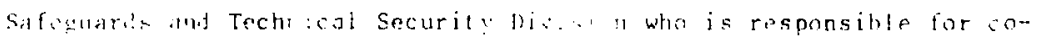
ordinating the receipt, shipment, cuntr and inventory of accountable 
nuclear materials in the custody of Sandia National Laboratories and who is responsible for reporting to the DOE in accordance with the reouirements specified in DOE Order 5630.

Protected area -- a specifically defined area (e.g., a fenced area, a building, or a segregated area within a building) enclrsed by physical barriers, which may form a buffer zone around one or more material access areas.

Radioactive materials -- a collective term which includes all radioisutopes, byproduct materials, radium, radium compounds, ald irradiated naterials.

Removals -- a collective term which includes all deletions or decreases in the quantities of nuclear materials in the inventory resulting from shipments, decay, normal operational losses, routine test, material unaccounted for, and other adjustments authorizid by the field of fice.

只eporting identification symbol (RIS) -- an alphabetic designation assizned by the Nuclear Regulatory Commission to identify licensed commerial suppliers and institutions as well as government contractors.

Rout ine test (RT) -- materials destroyed in weapon development activities associated with the use of high explosives, sled track tests, drop tower tosts, etc.

Safeguards control -- a system of controls intended to guard against the diversion of nuclear materials from authorized uses.

Scrap -- nuclear materials that are not usable in their existing form, are mixed with other materials necessitating chemical treatment to be rendered useful, and which may or may not be recoverable in an economical and safe manner.

Source materials -- a collective term which includes normal uranium, depleted uranium, and thorium (see "nuclear materials"). 


\section{Special nuclear materials (SVM) -- a collective cerm which includes}

all isotopes of plutonium, uranium enriched in the isotope uranium-233, and uranium anriched in the isotope uraniun-235 (ses "nuclear materials").

\section{Special reactur materials -- a collective term which includes all} physical and chemical forms composed wholly or largely of beryllium, boron10, hafnium, or zirconium.

Specification-type containers -- containers whose specifications are dasigned (accorting to the type of material) to comply with Department of Transportation requirements.

Transfers in -- materials obtained for a project from another project, but excluding materials obtained as a result of withdrawals.

Transfers out - materials removed from one project and provided to arother project. but excluding materials moved as a result of return .

Transport index - - the radiation level (in curies) measurad at 36 inches from the outer surface of the shipping container.

Two-person concept -- a minimum of two aurhorized porsons, each capm able of detecting incorrect or unauthorized use or handling of iuclear materials with respect to the task to be performed and who are familiar with pertinent safety and security requirements.

Unirradiated recurns - materials which, in thoir existing form, have not been subjected to reactor irradiation.

Withdrawals -- materials ohtained by DOE antractors from the DOE Production System for use in authorized programs. 
(WAPTE II!

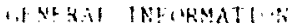

1. Nitivis

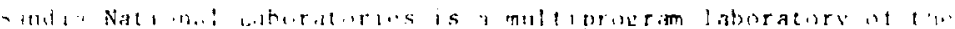

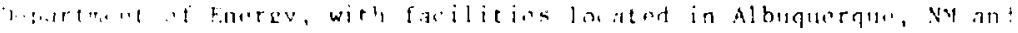

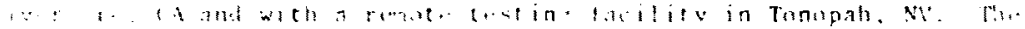

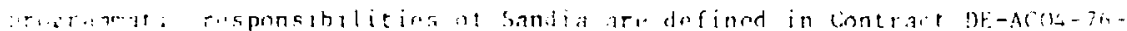

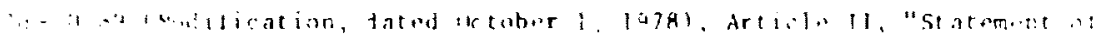

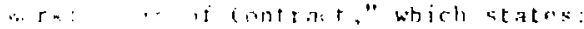

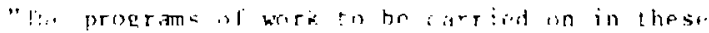
Aa litiles wili ha pincipally those related to wrapon

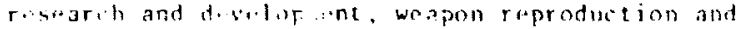
rendulion, preparation of weapnn field procrdurns and Tillabls, wasure survillances, weapon lostine, and

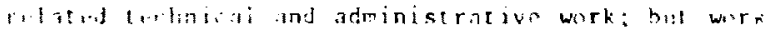

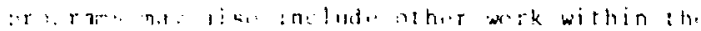

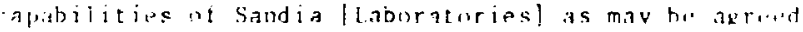
:.... in wrisin. ernotime in lit.."

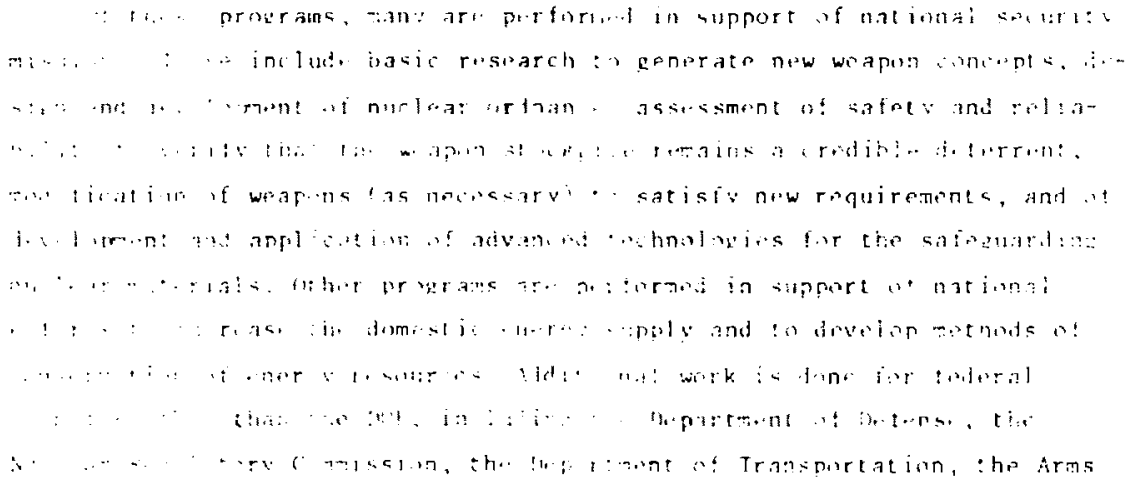


Control and Disarmament Agency, the National Aeronautiss and Space Administration, the National Science foundation, and the National institutes of Health.

A substantial number of thesp proprams involve thr utilization of nwilear materials, which must be handlad ir accordanc" with regulations at forth by the DOE and other governmental agenites. Contract DF-ACO4-7h-

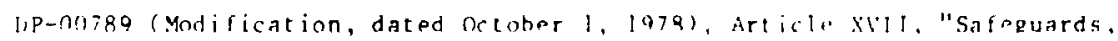
$\therefore$ int $r+3$ and Manaement of 'SS Yeterials"' states the contratual responsibility of sandia as follows:

\footnotetext{
"Sandia ! National Laboratories: shall, in a mann.r sat isfactory to the $[D \cap E]$, establish acrome ing and measuriment procedures, maintain rurrent risurds, and institute appropriate control measures fur 'ss Yaterials' in its possessicin commensurate with the nacional security and the economic value of the ss viaterials." Wherever a ficense is requirmed bu law or regulation. Sandia l Nat innal laboratori,s' shall not transfor or recoive possussion of 'ss taterials" inless duly licenself by the fDOE] to do so, and siall not transfer 'SS Materials' to anv persou not duly liconsed by the |DOEl to receive possession s: such materials. Transtors of 'SS Materials' will not be nadi without prior written approval of the cuntageting ifficer.

"Except as otherwise authorized by the fDOFI. 'SS 'taterials' in Sandia's possession, cuscody, or control, shall be used only for furtherance of the work under this Contract. Sandia shall he responsitlo for the control of such 'SS Materials' in accordance with Part 5630 of the [DOEl Manual and shall makr a part of each purchase order, subcontract, and other comitnent which it enters into under this concract. where "SS Materials" are involved, appropriate torms and conditions for the use of 'SS Materials' and th. responsibilities of the subcontractor or vendor regardine control of 'Ss Materials.' In tho case ar fixed price purchase orders, subcontracts or other commitmerts, the terms and conditions with respect to 'SS Materials' shall also include the financial responsililities, if any, regarding such items as losses, scrap recovery, and product recovery."
} 
Fiqure Ill-l illustrates a simplified flowchart for Naclear Materials. Figure lit-2 illestrates the corresponding flowchart for the naterial records that accompany nuclear materials. Nuclear materials are IItilized nrincipally in engineering and research directly related to the wign and development of nuclear weapons ordnance. The majority of en. riched uranium is utilized in operations in the reartor area where weapon parts and component pazkages are irradiated in studies of radiation effects and material characteristice. Other (nonweapon) activities in which nuclear aatrials are utilized include metallurkical studies, transportation safrety, electron-beam research, space fower-systems development, and aferisnace nuclear saf ty.

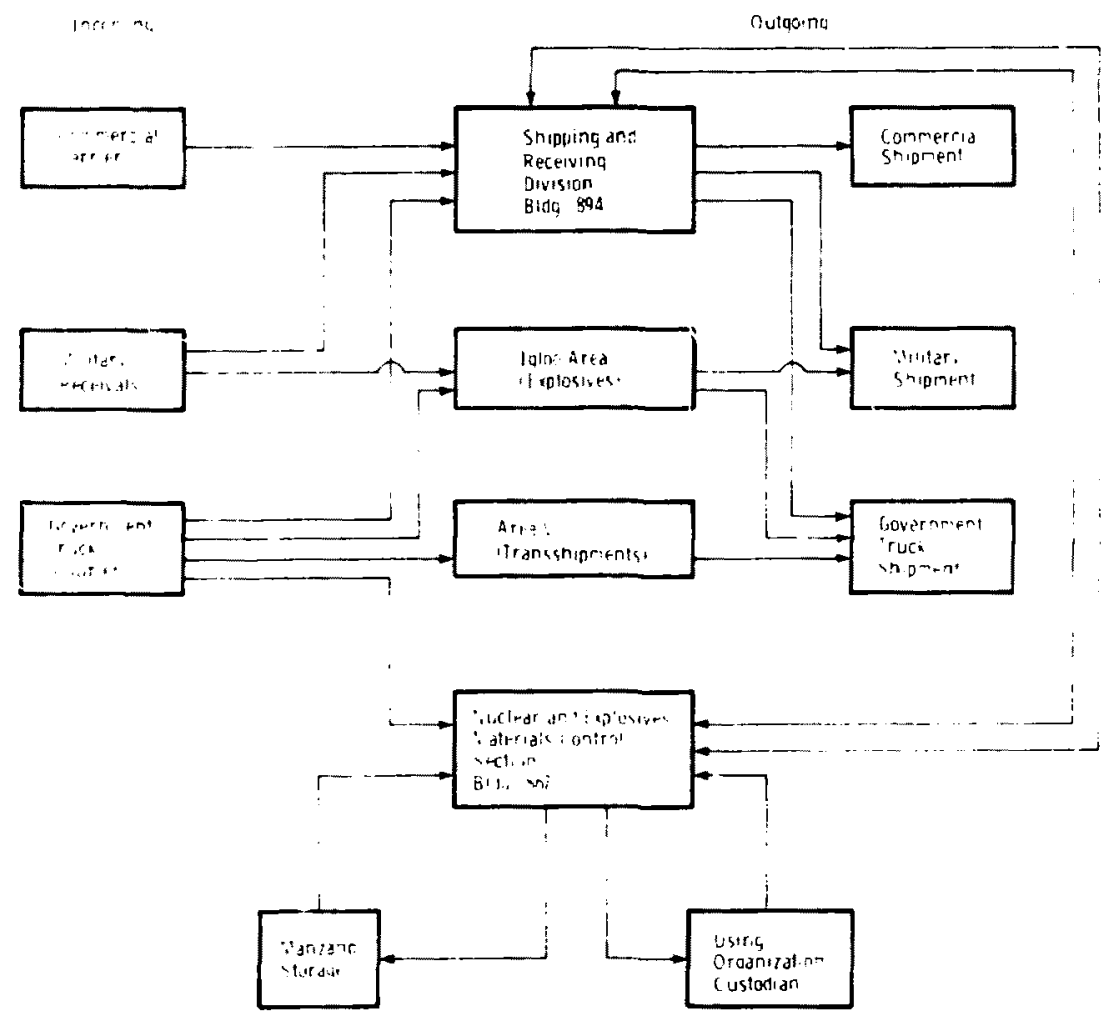

Figur. Ill-1. Simplifi.d Flowchare for Nuclear Materials 


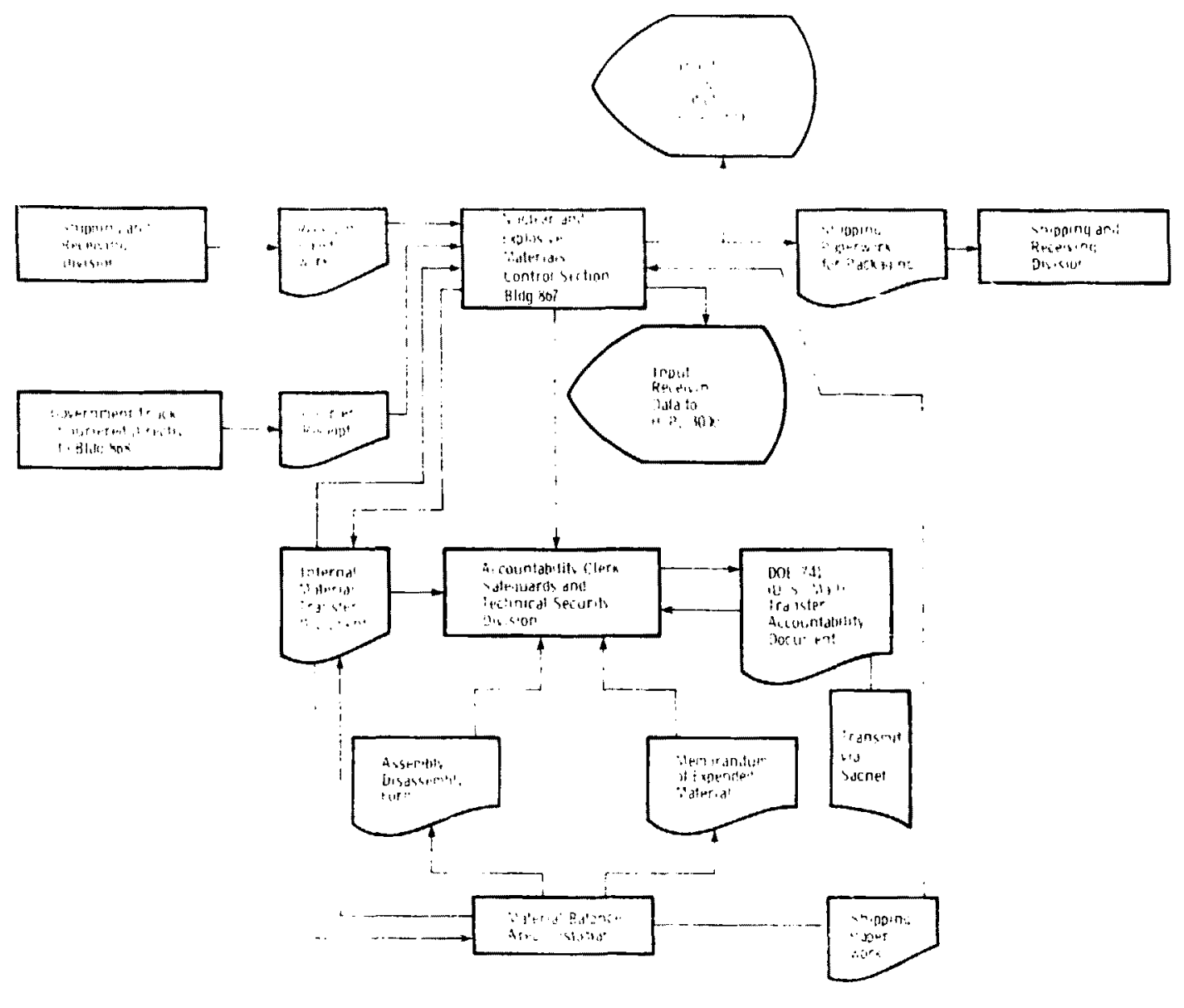

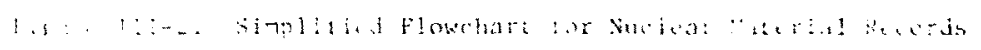




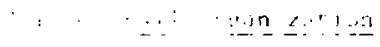

In supporl of these wide-ranging activitits, Sa jia maintains a staff . + in

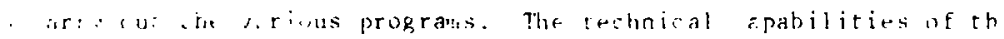

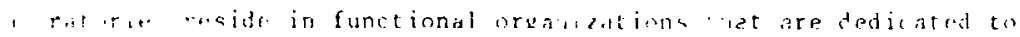

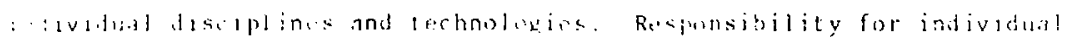

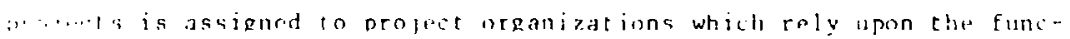

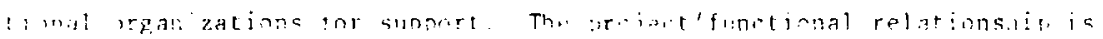

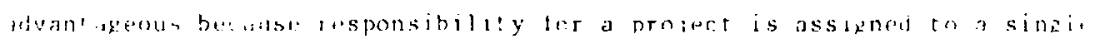

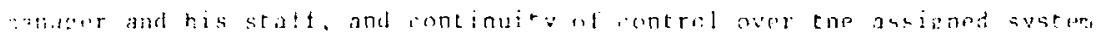

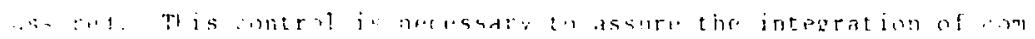

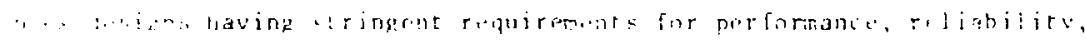

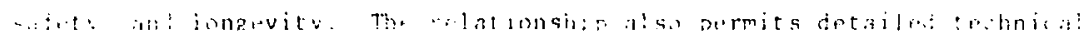

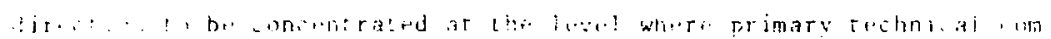

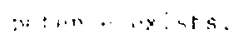

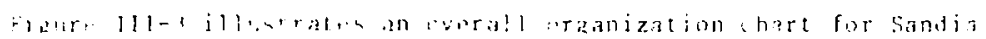

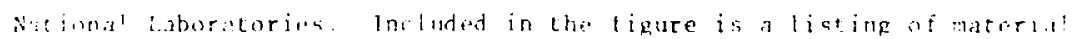

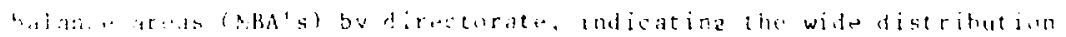

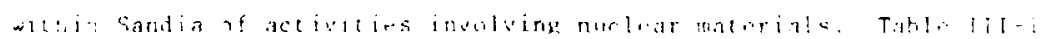

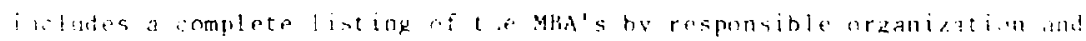
l.,. 


\section{Tab1e III-1}

Master Listing of MBAs

Responsible

MBA Organization

01

02

03

04

05

06

07

08

09

10

11

12

13

14

15

16
3423

3423

3423

3423

3423

3423

3423

3423

3423

3423

1545

1535

3313

4314

2552

1213
Location

Bldg. 867

Bldg. 867 and

Ig 100

Manzano-7055

Manzano-7049

Manzano- 7048

Manzano-7047

Area I

Manzano-7063

B1dg. 867-con-

structive receipts

Bldg. 867-material

held for shipment

Bldg . 892

B1dg. 6584,

Area III

Bldg. 869

Bldg. 809

Bldg. 805

Bldg. 892
Responsible

MBA Organization Location

$17 \quad 4311 \quad$ Bldg. 809

$18 \quad 1482 \quad$ B1dg. 892

$19 \quad 1414 \quad$ Bldg. 892

$21 \quad 1759 \quad$ E1dg. 820

$22 \quad 4323 \quad$ Bldg. 809

$23 \quad 4323 \quad$ B1dg. 809

$24 \quad 4333 \quad$ Bldg. 809

$25 \quad 1254 \quad$ BIdg. 880

$\begin{array}{lll}28 & 2167 & \text { BIdg. } 807\end{array}$

$\begin{array}{llll}30 & 1587 & \text { M0 } & 12\end{array}$

$31 \quad 1551 \quad$ Bldg. 860

$32 \quad 1766 \quad$ MO $42-45$

$33 \quad 5624 \quad$ Bldg. 634

$34 \quad 2531 \quad$ Bldg. 643

$\begin{array}{lll}35 & 4338 & \text { B1 dg. } 809\end{array}$

$\begin{array}{lll}36 & 582] & \text { B1dg. } 805\end{array}$

$37 \quad 1170 \quad$ Tonopah Test.

Range 
Table III-1 (cont)

\begin{tabular}{|c|c|c|c|c|c|}
\hline MBA & $\begin{array}{l}\text { Responsible } \\
\text { Organization }\end{array}$ & Location & $\underline{\mathrm{MBA}}$ & $\begin{array}{l}\text { Responsible } \\
\text { Organization } \\
\end{array}$ & Location \\
\hline 38 & 5822 & Bldg. 805 & 63 & 3423 & Manzano-7118 \\
\hline 39 & 1473 & $81 \mathrm{dg}, 841$ & 64 & 1587 & $\begin{array}{l}\text { Alice Springs } \\
\text { Australia }\end{array}$ \\
\hline 40 & 1137 & B1dg. $402 / 892$ & 66 & 3417 & Bldg. 894 \\
\hline 4] & 5612 & $\begin{array}{l}\text { Bldg. } 805 \\
81 \mathrm{dg} \cdot 806\end{array}$ & 67 & 2141 & Bldg. 870 \\
\hline 43 & 1112 & $\begin{array}{l}81 \mathrm{dg} \cdot 806 \\
.1 \mathrm{dg} \cdot 868\end{array}$ & 68 & 4363 & Bldg. 835 \\
\hline 45 & 2514 & $B 1 \mathrm{dg} \cdot 807$ & 69 & 2354 & $\mathrm{Bldg} .802$ \\
\hline 47 & 5846 & $B l d g .894$ & 70 & 1244 & Bldg. 880 \\
\hline 48 & 4216 & MO 33 & 72 & 4221 & BIdR. 9990 \\
\hline 49 & 5623 & Bldg. 835 & 73 & 2355 & Area II \\
\hline 50 & 5111 & $\mathrm{~B} 1 \mathrm{dg}, 884$ & 74 & 5846 & Bidg. 892 \\
\hline 51 & 4453 & $\begin{array}{l}\text { Bldg. } 6588, \\
\text { Areid } V\end{array}$ & 75 & 5836 & $\begin{array}{l}\text { Bldg. } 6630, \\
\text { Area III }\end{array}$ \\
\hline 52 & 5836 & 14 & 77 & 3423 & Bldg. 867 \\
\hline 53 & 5842 & Bldg. 808 & 78 & 3423 & Igloo Area \\
\hline 55 & 5132 & Bldg. 806 & 79 & 4341 & B) dg. 809 \\
\hline 56 & 4342 & $\mathrm{Bld} \cdot 809$ & 80 & 2164 & $\mathrm{Bldg} \cdot 807$ \\
\hline 58 & 1552 & Bldg. 860 & 81 & 1112 & Th \\
\hline 59 & 1727 & $\mathrm{Bl} \mathrm{dg} \cdot 880$ & 82 & 5154 & Bldg. 807 \\
\hline 60 & 2352 & $\mathrm{~B} 1 \mathrm{dg} \cdot 802$ & 84 & 4314 & Cannon AFB \\
\hline 51 & 4552 & $B l d g .890$ & 86 & 4536 & T4 \\
\hline 62 & 2353 & $\mathrm{Bldg}, 802$ & 87 & 1485 & B1dg. 840 \\
\hline
\end{tabular}


Table III-1 (cont)

\begin{tabular}{|c|c|c|}
\hline UHA & $\begin{array}{l}\text { Respnnsible } \\
\text { grganication }\end{array}$ & location \\
\hline Q9.9. & 3423 & Iglon Arar \\
\hline$R \cdot g$ & 4536 & Wouds Hole, Mass. \\
\hline 4] & $\therefore \therefore 36$ & $\begin{array}{l}\text { Sia Hed Prourath } \\
\text { Sitr. }\end{array}$ \\
\hline $4 ?$ & 1555 & $M O 81$ \\
\hline$\because 4$ & $13: 1$ & BIrls. 2.60 \\
\hline 4: & 1721 & $B l d \mathrm{c}, 820$ \\
\hline 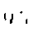 & $\therefore 4 ? ?$ & $81 \mathrm{dg} .892$ \\
\hline
\end{tabular}




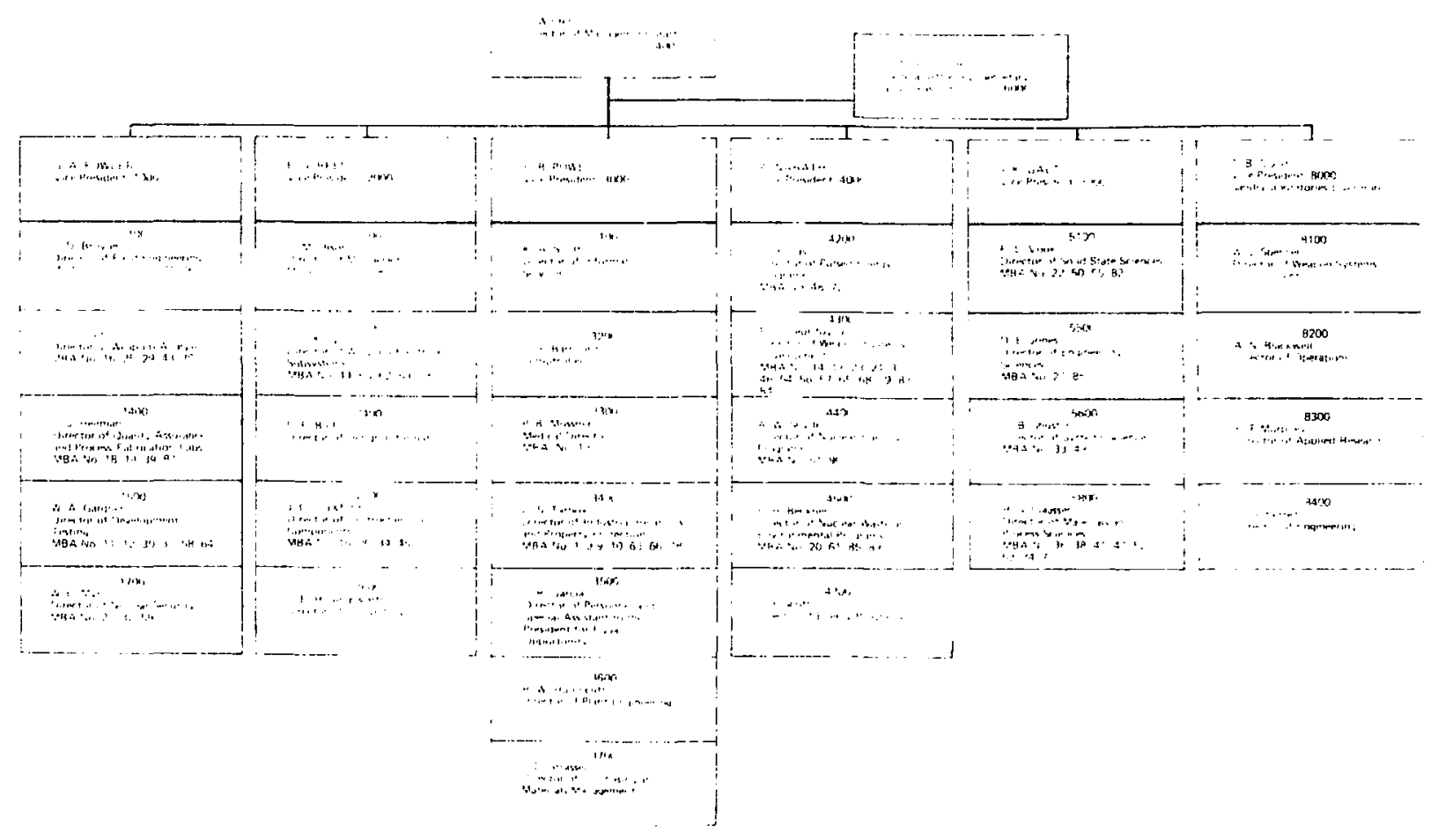




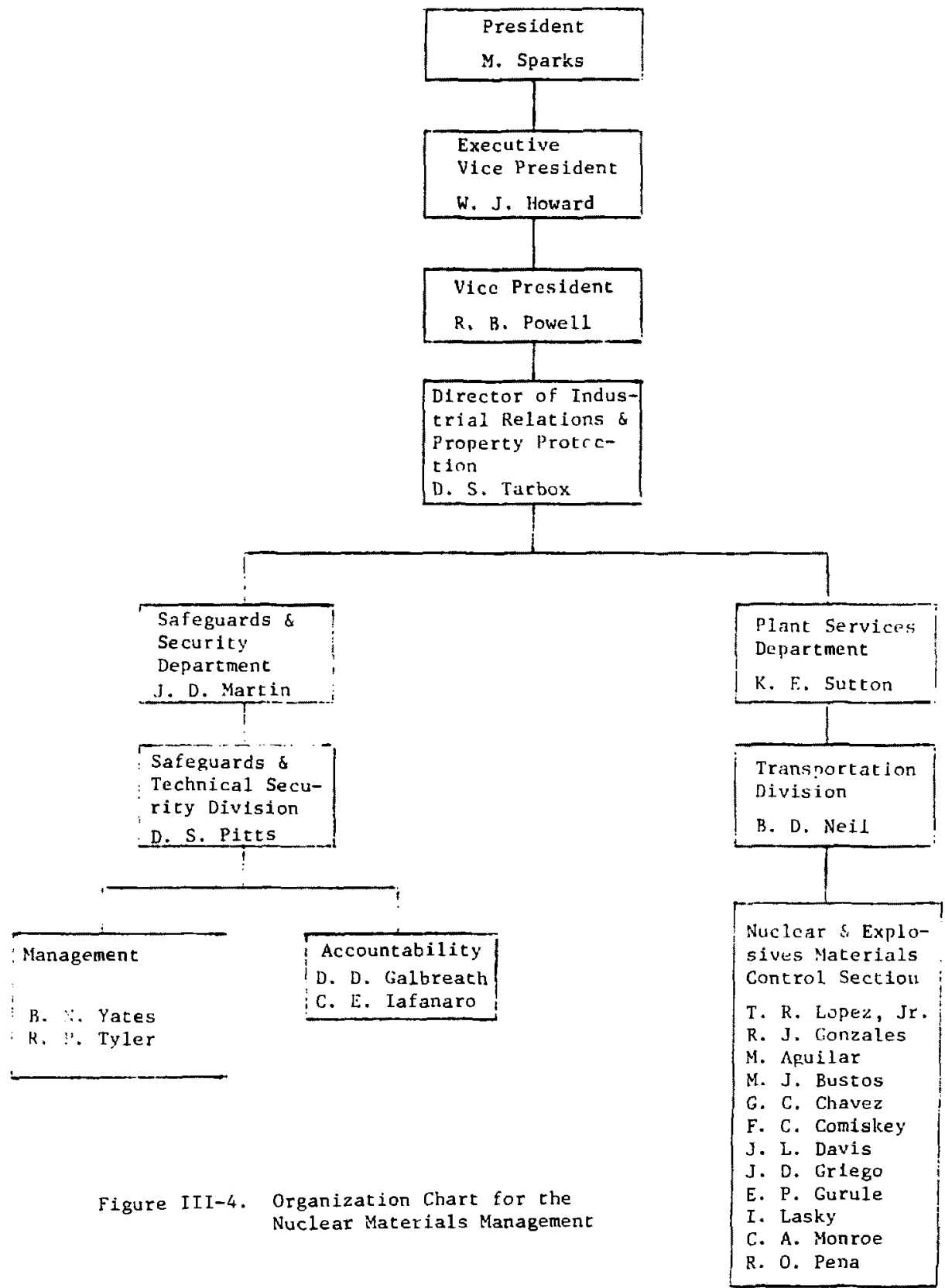




\section{Responsibilities}

\subsection{Nuclear Materials Management Organizations}

The Safequards and Technical Security Division assumes primary responsibility for the management and accountability of nuilear materials. Specific responsibilities are to:

- Maintain records of accountable nuclear materials.

- Report inventory changes to DOE/ALn and to the Nuclear Materials Minagement and Safeguards System (NMMSS) in Dak Ridge, iN.

- Review DOE-189 schedules and purchase requisitions for nuclear radioactive materials.

- Initiate analytical studies, when warranted.

- Perform continuous random sampling, 100-percent audits, and utilization and storage reviews.

- Reconcile custodians' inventories.

- Satisfy reporting requirements to the DOE.

The Nuclear and Explosives Materials Control Section assumes primary responsibility for the physical control of nuclear materials. Specific responsibilities are to:

- Receive all nuclear and radioactive materials.

- Measure the content of weighable nuclear materials.

- Verify the presence of nonweighable nuclear material utilizing nondestructive assay equipment (SAM II). 
- Trimsport mirlcar materials.

- Store nuclear matiolals being held for futura usa.

\section{$\therefore$ Support Groups}

Soveral organizations internal and external to Sandia assist th.. nue lear materials management organizations ill performeng management, contrul, and accountabiliey functions, Organizations chat normally Ahport the nuclear tnaterials nanagement organizations (along with the ir aria ar respensibility) include the followng:

\subsubsection{Fnvironmental Health Department}

- Bipens and monitors all sources.

- Phvsically moves all surures.

- Moniturs all receipts containing plutonitum.

- Monitors all receipts with questionable radiation.

- Thecks all ralioactive-material locations and advises using amployees of potential hazards.

- Monirors all nuclear and radioactive shimments.

- Makis all burials in the Sandia herial grounds and roords their locations.

- Checks activated criticality alarms and maintains al arms.

- Monitors continuous air monitor (CAM) and remote air monitor (RAM) indicators in Area $V$. 


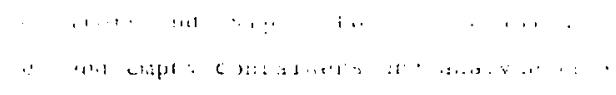

.

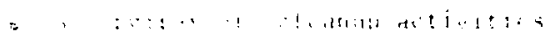

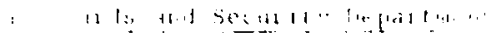

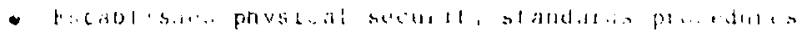

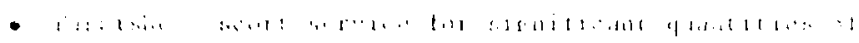

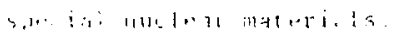

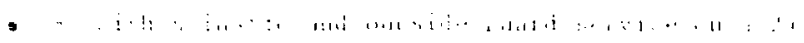

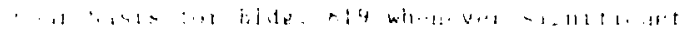

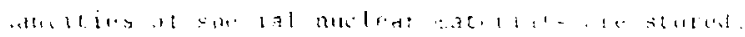

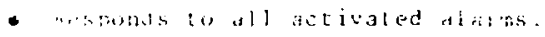

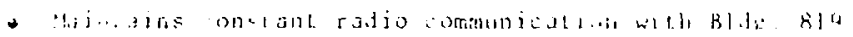

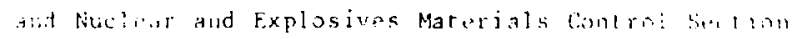
. ini i. i. s.

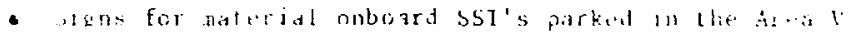

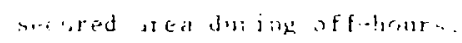

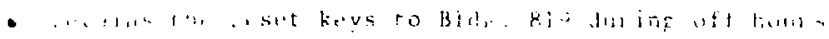

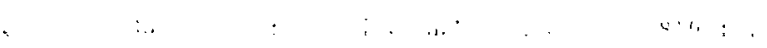

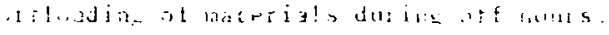

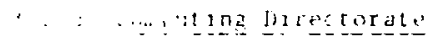

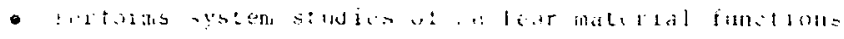

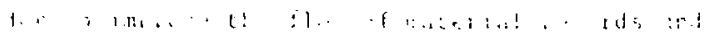

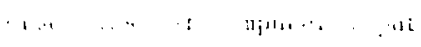


- Develops and maintins a computerized system with the capabilities required to meet DOE and Sandia requirements.

- Writes and maintains computer programs to implement the computerized system.

- Produces and transmits reports and messages.

\subsubsection{Shipping and Receiving Division}

- Packages nuclear materials in accordance with fereral requlations based on information on the shipper (property action form) and the hazardous malerial shipnent form.

- Labels and stencils containers.

- Requests the Healih Physics Division to monitor packaged materials.

- Ensures that DOT requirements are satisfied.

- Ships materials.

- Receives materials and notifies the Nuclear Materials and Explosives Control Section of radioactive and nuclear material receipts.

\subsubsection{Transportation Division}

- Moves large and heavy materials accompanied by a control clerk from the Nuclear Materials and Explosives Control Section. 
- Moves explosive materials as approved by the Safety St andards and Engineering Department.

- Provides trucks, forklifts, and other oquipment for loading and unloading of materials at the Manzano Storage structures.

- Prnvides tiedown service on SST's.

\subsubsection{Traffic Management Division}

- Arranges for transportation and courier support from the Transportation Safeguards Division of the DOE.

- Receivr.s and convevs rotification of expected materia: arrivals.

\subsubsection{Safety Standards and Engineering Department}

- Checks pressure vessels.

- Checks facilities and equipment for unsafe conditions.

- Reviews, evaluates, and authorizes the presence of HE in the same physical location as nuclear materials.

\subsubsection{Physical Standards Division}

- Provides certification and calibration of weighing equipment.

\subsubsection{Plant Engineering Planning Department}

- Designa, builds, and modifies facilities.

- Provides fire protection.

- Maintains powet, lights, heat, water, etc. 


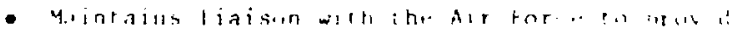

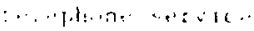

rit Icalicy Safezy C.mmit!:

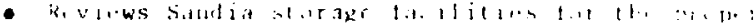

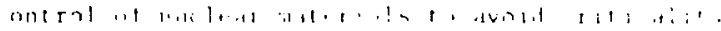

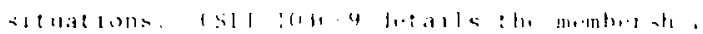

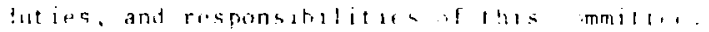

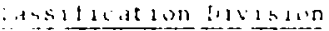

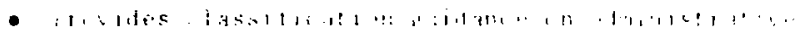
I I.titis.

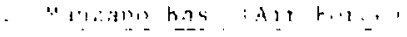

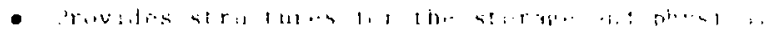

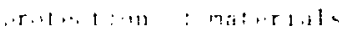


rhantrik !

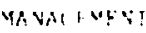

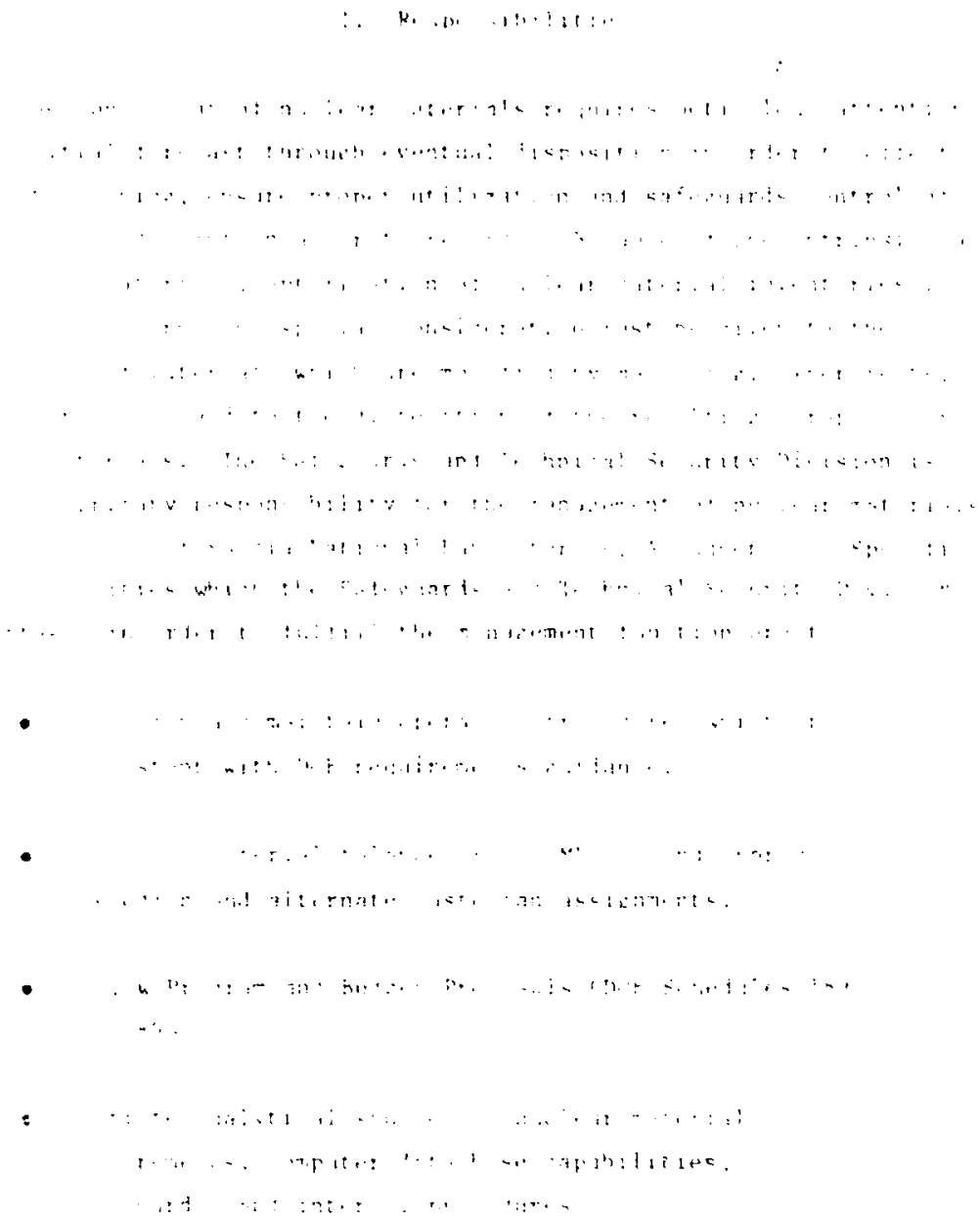


- Prepare annual requests to using organizations to provide descriptions of proposed project actjuities for the 12-year forecast.

- Summarize the annual forecast requirements reported by the Directors of using organizations and submit the zomploted forecasts to DOE/ALO.

- Reviww and approve purchase requisitions for nucluar nat.rials.

- tstablush nat maintain a propram for appraisine th. status of purchise orders and contract arfilities an! ving surluar materials.

- Entalisir and mainlain a projoct control systim tur ascessing :he actual activity oi nugluar naterials as omilared with the foracasted activity.

- írivar erials manjement plan (MMP) submitced anmuallv in May to DOF/ALO. DOE Appendix 7451 provid,s spe, ifi. anitelines for preparation.

- Pitepare the assessment report submitetd annuolly ir sivember to DOElALO. The report is a summarv af tho inrent inventory, how materials are beinz usted and which materials are being held for specific purposes and projected dispocition.

- Verify that iustodians and users report project changes prompty in order to update the computer master records and to provite -imely notification to the Nysss.

- Verify that using organizations comply with ali procedural requitements. 
- Indoctrinate new custodians and annually review the using organization's responsibilities with current custodians.

- Review and approve external transfar accountability forms (Form DOE-741).

- Assure that requests for matirial transforabetwen approved programs have bren received and authorized prior to the physical novement of material and notification to NMMSS of such transpers.

- Request althorization from DOE/Ain to removi materials whirh are antiripated to be expended in experinents or tests from the records.

- Establish and maintain procedures for the control and disposition of scrap and audit using organizations to ensire compliance with these procedures.

- Submit sctap evaluation reports to Milalo and request diuposition instrut ions from DOE/ALn for scrap and excess matorials.

- Arranze shipping schedulas for serap or execsa mazerials witin reprocessing plants, based upon the disposition instructions issuet by DOE/Aln.

- Provide liajson wilin suppliers, mijitary agencies, and the DOF. regarding activities involving nuclear and other accountable materials. 


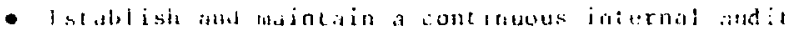
program to ensure that material contro: procedures aet aflective and that these procedures arp being complien within daily operations.

- Conduct continuous ut ilization and storage reviews during audits to ensure that materials are being ut ilized properly and that the nuclear material inventury is being optimized.

- Assist DOE/ALD in conducting annual safeguards and security surveys and nuclear materials management appraisals.

- Initiate the necessary actions required to satisfy the recominendations made by internal or external audit teams.

- Review monthly MSR and project balance reports from ALO and Oak Ridge to verify balances with Sandia accountability records.

- Prepare reports of expended nuclear material based on the information supplied by using organizations on "Modification/Expenditure of Nuclear Materials" forms. 

that are a:sioned to a single MBA may be used in more than one geographi“l Jantion, boweser, whenever possible, the single geographical 1.9: linn. : agle cusiodian concept is inllowed. An MBA working group

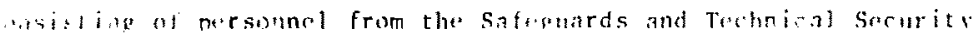
i isisin and the N.l lear and Explosives Materials Control Section ments

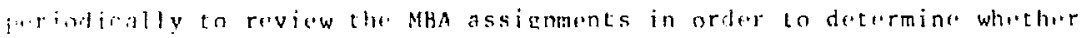
How curent assiznments are consistent with the newds of the laborntories.

\section{$\because 1$ Prowdures for the Authorizacion of On-Sit. MRA's}

Horingible Organization

Is: al "ramization

- Castodian/Alternate Custodian)

inta.n:
Action

1. Surbits it request to the Safio guards and Technical Security Division for the authority in recaive nuclear materials, justifying the nesd for such materials and indicating their intendfed us.

2. Designatis a custodian and altirnate custadian.

3. Completos redeliartion forms, Form SF 3004-C, "Authorization Sor Retioligation" texhibic 5 , Chapt.r. $x)$.

4. Approves thr custodian and altrenate custodian and signs the redelegation forms.

5. Forwards the approved forns to th. Safeguarts and Technical Security Divisinn 
Safeguards and Technical Security Division (NMR)

(Accountability Clerk)

(Intirnal Auditor)

Whenever changes in custodianship occur, the newly assigned custodian/alternate custodian is required to submit an approved redelegation form to the Safeguards and Technical Security Division as specified above. In addition, a 100\% physical inventory is performed by Safeguards and Technical Security Division personnel and accompanied by both old and
6. Signs the custodian and alternate custodian redelegation forms and assigns an MBA number to the new material balance area.

7. Inputs to the computer the MBA number, inventory report format, inventory frequency, creation date, termination date, site type, location, custodian's and alternate custodian's name, organization, phone number, duty date, and briefing date in accordance with the Nuclear Materials rompute - User's Guide.

8. Files the redelegation forms.

9. Schedules indoctrination metings with new custodians and alternate rustodians to:

9.1 Provide thom with a copy of the users' manual.

9.2 Discuss responsibilities defined in the users' manual, especially regardina unique circumstancas in the MBA.

10. Schedules review meelings annually with all custodians and alternate custodians to:

10.1 Review responsibilities and discuss problems encourtered in or with the MBA, and any new requirements that require updating of the users' manual. 
new custodians. This ensures that the newly assigned custodians are

cognizant of the material for which they are accountable and its location.

\subsection{Procedures for the Authorization of off-Site MBA's}

\section{Resconsible Organization}

Using Organization
Security standards and Investipation Division

Safeguards and Technical Division (NMR)

\section{Action}

1. Submits a request to the Safeguards and Technical Security Division for authority to receive nuclear material at a designated off-site location. Justifying the need for such material and indicating intended use.

2. Designates a custodian and alternate custodian.

3. Piovides date of shipment to the off-site location and date of return.

4. Follows procedures in 2.1-3 through 8 for custodian/ alternate custodian approval.

5. Provides security data for the off-site location regarding storage, alarm systems, and patrol frequency to the safeguards and Technical Security Division.

5. Prepares site plan for the Sicurity off-site MBA.

7 Forwards site plan to DOE/ALO for approval prior to each shipment.

8 Authorizes shipment of material following receipt of DOE/ALO approval. 


\section{Review of Program and Budget Proposals}

Program and budget proposals required by the DOE are submitted by using organizations involved in non-DMA programs, such as reactor research programs and programs funded by the Nuclear Regulatory Commission. These proposals, submitted on DOE Schedule 189 (Form SF 92ll-F), "Program and Budget Proposal" (Exhibit 1, Crapter $X$ ), are intended to provide the DOE with a detailed description of the proposed program along with the budget allocations required for the program by fiscal year.

For those programs that require the utilization of nuclear materials, DOE Schedule 189a, "Program and Budget Proposal, Nuclear Keg.slatory Research Progran" (Exhibit 2, Chapter $X$ ) is submitted in conjunction with DOF. Schedule 189 in order to specify nuclear material quantity requirements for the proposed program. This schedule includes justifications, specifications, and final disposition plans for the materials along wit. the DOE project number to be charged.

Both aocuments are completed by the using organization and forwarded to the Budget and Financial Planning Department. A copy of each is sent to the Safeguards and Technical Security Division where the information is used in forecasting of materials and long-range planning.

Both forms are ultimately reviewed and approved through the vicepresidential level at Sandia and then forwarded to DOE/ALO for authorization. 


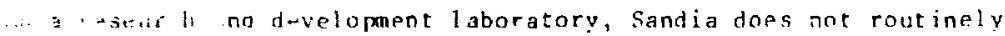
purtorm anilytical studies of nuclear material requirements. The SafeZuards and Technical Securicy Division performs quarterly evaluations of matrerial ui iliaginr by comparing matarial withdrawals with material fore-

ist:. W addition, materials managunt options related te such maters as propusad programs, nuclear materi-l requircmints, computer daba-base. capabilities, seieutards, and internal proredures are continually revicurd and analyzed. Whanever warranted, analytical studiss are initiated, and the results of sich studies are utilized in improving the nuclear materials inanagement program.

Ustug organizalions are fexpected to pertorm the necessary asisessment uf risks ussociated with meeting prontammatic objectives, health and saf:.ty tantirds, safeguards requirements, etc.. and to formulate untingeniv plans caisistent with sound program manacenent. The Safreuards and Techoiral Security Division remains informed of such studies to ha incorporatid into the Materials Management Plan.

Risks, iyntingencies, and options arr also provided to the Safeguards and Tectoniral sfourity Division whenever materials haing hold for futura iss in a prof:am are to he transferred to muther concractor in risponst lo an urecut requirement. 


\section{Forecasts}

Annual forecasts are required for the following nuclear materials:

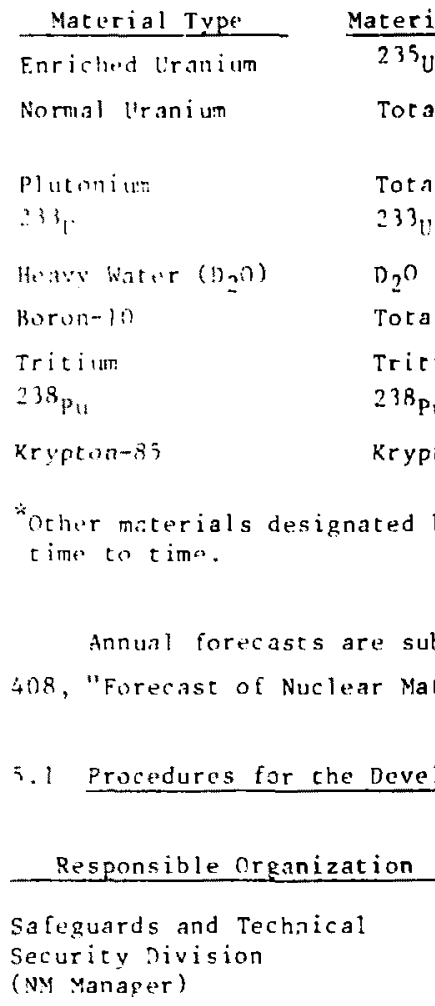

Using Organization (Director)

\section{Reporting Units}

Nearist whole kilogram

Nearest whole kilogram $100 \mathrm{ks}$

Noares: whole kilogram

Nearest wiole kilogram

Nearest whole kilogram

Nrarest whole kilogram

Nearest whole gram

Nenrest whole gram

Nearest whole? curie 
Safeguards and Technical Security Division (NM Manager)
4.1 Requirements are reported by quarter for the first 2 years of the 12-year forecast and by year thereafter.

4.2 Forecasts must reflect both firm and probable requirements and must include unirradiated returns, irradiated returns, and burnup and losses anticipated.

5. Prepares a briff description of program objectives and of known risks/contingency plans relared to the program.

6. Submits the completed Forns DOE Ans along with the program description to the Safeguards and Technical Security Division in late November (bu the date specified in the reourst letter.

7. Reviews the forecasts and consults tin originator whon vague or inclusive dat a appear.

8. Checks the forecasts against Proeram and Budget Proposals (for those proprams for which DOE Schedules 199 and 189 a have been submitced).

9. Consolidates the requirements by project and material type.

10. Prepares Forms DOE 409 in accordance with DOE Order 5630 , Part 1 , reflecting the composite requirements of all Sandia programs.

11. Files a copy of the completed forecasts and submits the forecasts to DOE/ALO in early January (by the date specified in their aniual request letter).

12. Prepares revised Form DOE 408 as changes to known reguirements occur. 


\section{Procurement and Conlract Activitios}

l'einjoranizations are responsible for initiatine purchas requisitions to oblain matrials for approved programs. Purchasi analvats prepare purchase requisitions based on information suppliad by the using: oreanization and guidelines provided in Purchasing Instructions, such as P. 1. 5.015, "Routing of Shipments," and P.1. 8.06-13, "Procurement of spieial ltoms." All requisiztions for radioactive and nuelear materials ar. then routed through the Sateguards and Techuical Security bivision fur vine ial approval priur to the placement of a purchase order.

\section{6.) Procedures int the Roguisition of Radionctive and Nucluar Materials}

Hosponsibla. Organizat ion

Hsin! rasuiatinn
Purchasing, Stores, and Traffi: Managemone Department (Purithat Ana! 1 st)
- A

1. Proviales the purchasr analvs: with the information necessary to order the required inatirials.

1.1 nn orders where Sandiaordered mencrial is to be used by anriher contractor in a manufacturing process special instruct ious must be provided stating disposition instrurtions for the scrap, ixcess, and finished product, or stating that a request for such instructions will be: submitcred followins processing.

2. Prepares a purchase requisition on Form SA 6430-RD, "Purchas" R.quisitinn" (Exhibil", Chapter $X$ ).

2. 1 Ruilding 819 is designated as the delivery point. 


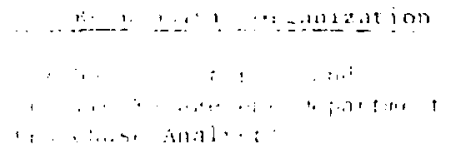

iat, entats and Trianifal

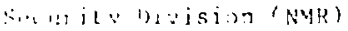

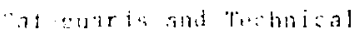
sointity bivition (x) yolity,

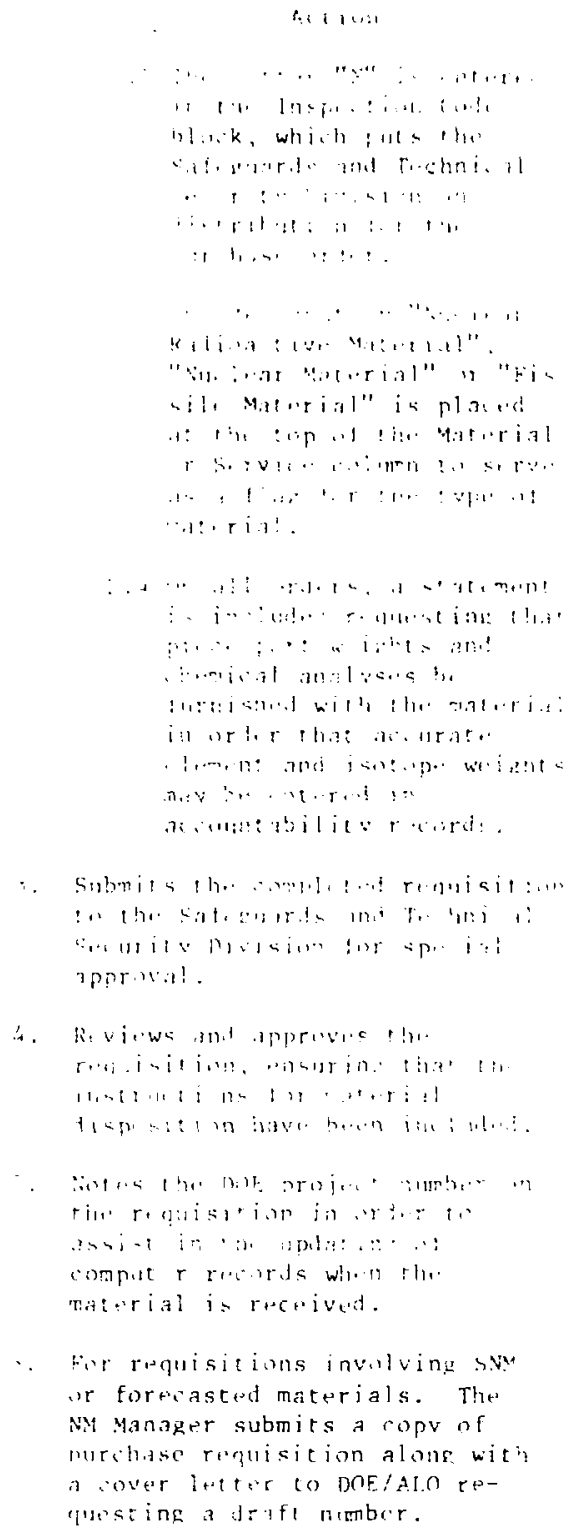




\section{Responsible organization}

bafeguards and Techrical

Security Division (NMR)

Pur:basine, Stures, and

Tr:it i, s!anagement Department

(Purihast Analyet)

Puribisina Department

(bivitr)
Action

7. Upon reply from DOt:Alr, adds the assigned iraft nimber to the requisition.

9. Sends a rope of the porrisud purchase requisition tis the. Nucloar and Feplosives Molurials Control Section (Building Rh? south) and a cupe to the acrount. ability clerk: retains onpy in

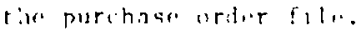

9. Roeurns the approverel purchase requsition to the murchas. analvat.

10. Furwards the approved nurehase requisition th the buver.

11. Prepares and places linte purchase order on Form SF hill-A.

"Purchase" Order" (Fxhibit 1. Chapter ViII).

12. Distributes conv if pierthase order to Safeguards and Tochnical Security Division.

\subsection{Ordering Nuclear Materials}

In view of the high cost of nuclear materials production or purchase, it is inportant that nuclear materials used for DOE programa ha offectivel $\because$ inanaged.

Th, dezte of responsibility for managing nurlear materials l:nd,r contract is relaced to the specific provisions applicabli tomatirir s nanagenent.

Tha purchasing department will, with articles or staterints in the body of the order, ensure effective materials manaement. 


\section{G.?.: Proemalu-s for Ordering Nuclear Materiais}

Kespinsible Organization

Suratasina lupartment (BL. :
Artion

1. Pl7:? : 1, 1, r

$$
\begin{aligned}
& \text { - ? is: antrat pland un }
\end{aligned}
$$

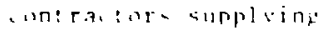

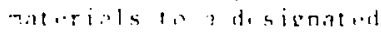

$$
\begin{aligned}
& \text { - and ant inter lar } \\
& \text { "inu! a. turing firisin! }
\end{aligned}
$$

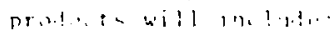

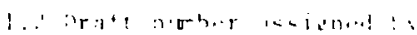

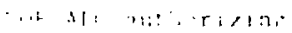

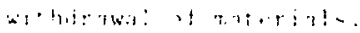

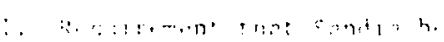

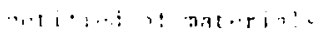

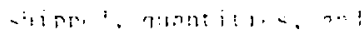

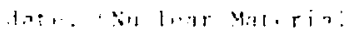

$$
\begin{aligned}
& \text { 1 un r...? ?. . }
\end{aligned}
$$

$\therefore \quad ?]=\quad$ ?

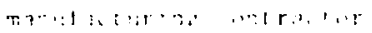

i- $\quad \vdots: i, j, \ldots$

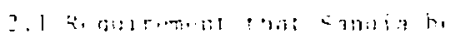
matíl, : materiais

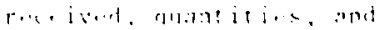

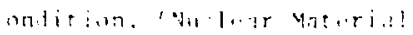

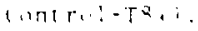

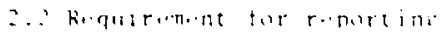

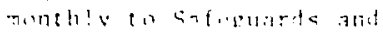
enhniral Sesuritu livision .] plivicical invantervand 7.3t rial compocition.

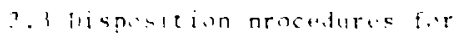
the ? inisherf profuse and residin: material not incorporated ineo product.

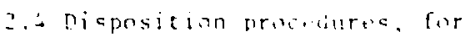
materials not to be returned (a) sandia, must be author$i z \cdot d$ br DOF:ALC. 


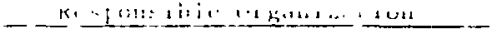

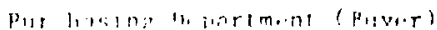

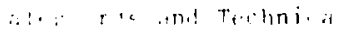

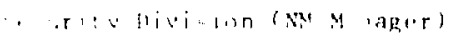

$\therefore \therefore \quad \ldots$

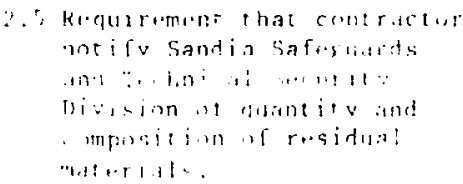
untify Sandia Safustiarts

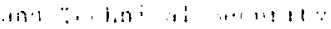
dri

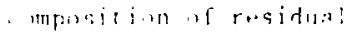

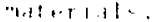

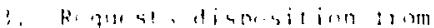

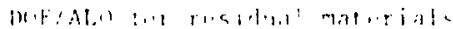

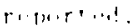

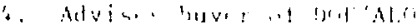

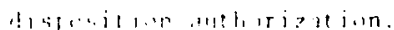

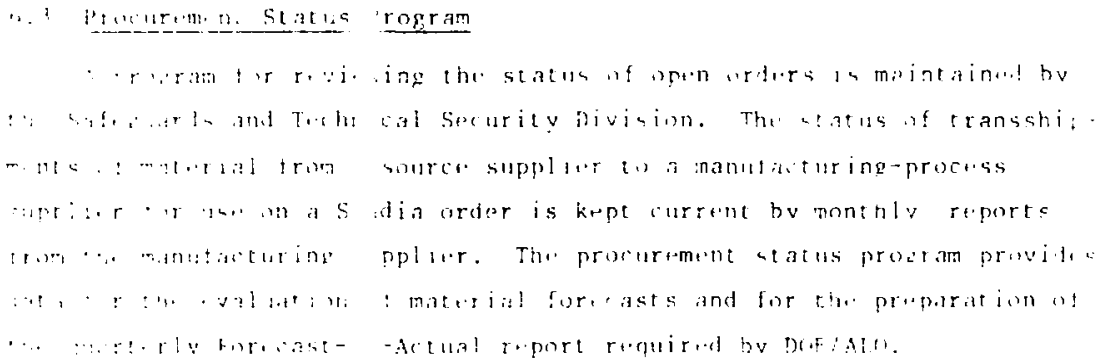




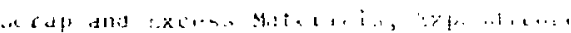

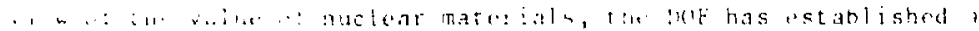

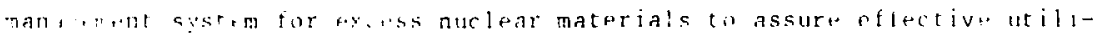

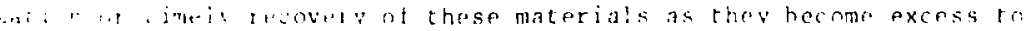

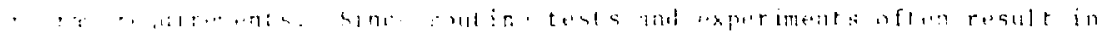

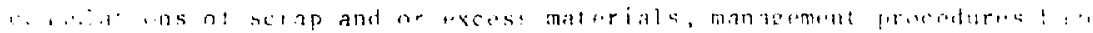

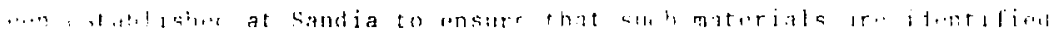

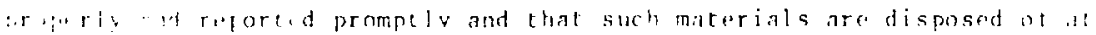

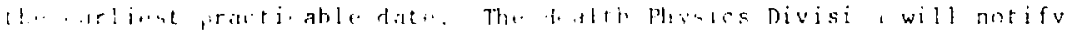

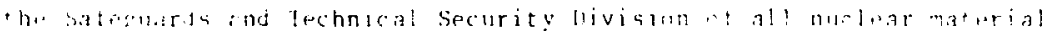
plrked ur fi: burial.

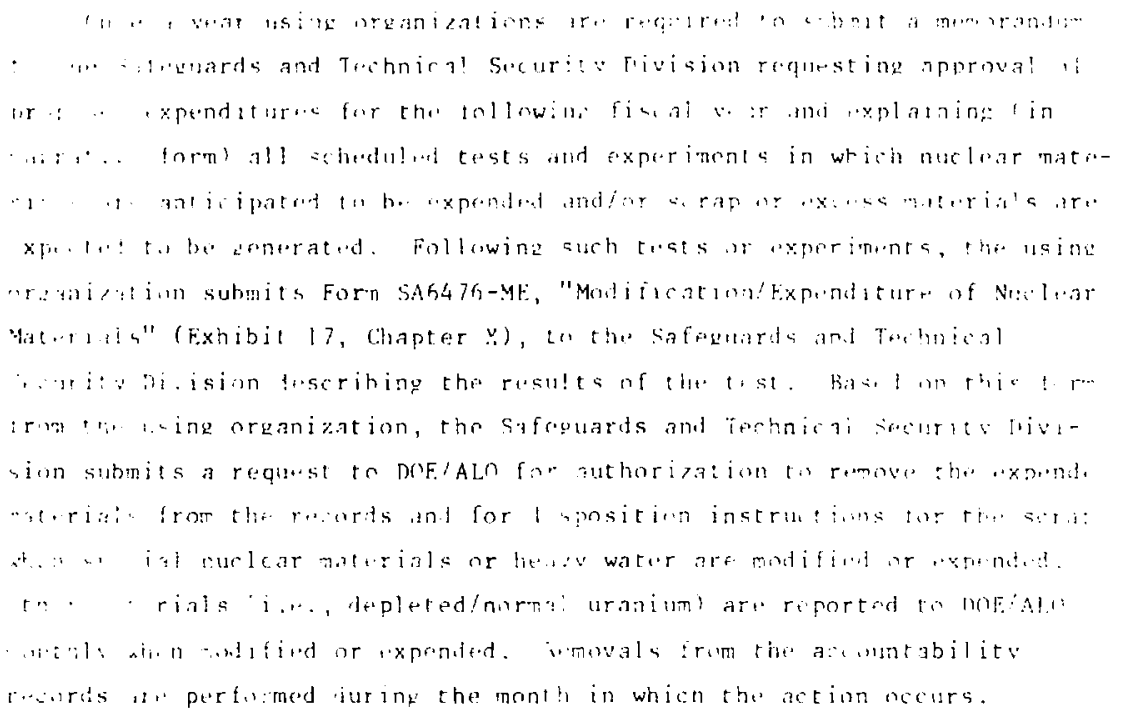


Specific procedures governing the disposition and accountability of scrap are described later in Sections 7 and 8 , Chapter $V$ and Section 6 , Chapter VI.

\section{7.l Procedures for Ohtaining DOE/ALO Authorization for Scheduled Nuclear Material Expenditures by Fiscal Year}

DOE regulations require that approval be obtained in advance for any changes in size, shape, form, or weight of nuclear materials. This requirement applies to such activities as machining of nuclear materials, chemical action on nuclear materials, ind destructive tests (either with or without explosives).

Blanket authorizations for estimaled guantities of material types 10 , 81,87 , and 88 are granted for a fisca year upon request and thr actual quantities expended are reported monthlv by memorandum to DOE/ATO.

SNM expenditures must be requested and authorized on an individual sasis.

Responsible Organization

Using Organization
Action

1. On ir be:fore September 1, prepares and submits a memorandum to the Safeguards and Technical Securit! Division, requesting approval of proposed activities for the following fiscal year and explaining (in narrative form) all scheduled tests or experiments.

1.1 For each activity, the memorandum includes the nuclear material type, the quantities of scrap andior excess material residues anticipated, the time frame in which the activity will be accomplished, the DOE-approved program and Sandia case number, and expected level of radiation at the surface of the macerials (if the materials are to be subjected to radiation). 
1.2 The completed memorandum is signed by the division supervisor of the using organization.

1.3 The memorandum may be amended throughout the year but, for any proposed activity, approval must be abtained prior to conducting the tests nr experimenes.

Safeguards and To chnical security Divisiol (NM Manager)
2. Prepares and submits a memorandum ro DOE/AJi), restating the justifications provided by the using organization and requesting authorization to remove the materials from the records.

2. I DOE/ALO determines the manner (routine test, normal operational toss, material unaccounted for, .re, ) in which muclear materials ar" removed from the records. 
8. litilization of Material

Materials are procured for specific programs or transferrel frov: recently completed to new programs. Project numbers assigned define the area of activity. Transfers of material are reviewed by the Nuclear Materials Reprosentative and Nuclear Materials Sanagcr for program and prijot number changes. The internal auliog refows usage dur ing audits questions inactive materials, and cefers serial nombers of itoms inactive for lwo surowssive audit periods to the Nucloar Malerials Manigur ur furthrer investigation.

Serial numbers, descriptions and weights of materials no longrer required are submitted to DOE/Ato as excess and disposition is requested. 


\section{Management Reports}

Accurate and timely reporting to the DoE of material requirements and utilization ar: essential to effective nuclear materials management in optimizing the nuclear material inventories of competing programs. in allowing chw cocal resnutces to meet program objectives, and in planniny for production, prosessing, and, rocurement of additional resources, as nowded. The Safeguards and Technical security Division is assigned the prinary rasponsibility for prcporing and issuing reports required by th: Int based on the information obtained from using orgarizations and compularizad accolnt ability records. Additional roports are generatrd internally to assist the Safeguards and Technical Security nivisian in p*torming management functions.

\section{I Fiernal Reports}

Ti, [o]lowing reports are prepared in compliance with Dur: roguiritinents:

Forecasts - Annual forecasts of nuclear material requirements aro developed and submitted to DOE/ALO in early Januar: on Form DOE 408, "Forecast of Nuclear Material Requir"ments" (Exhibit 3, Chapter $X$ ). Forecasts incluie quartarly withdrawal requirements by material type and isotope wi:ight for the 2 succeeding yoars. and ammal requiremeats foi 10 addiciona years. Forecasts al so include scheduled returns.

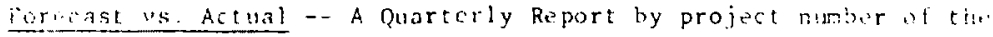
fiscal year beginning inventory plus forecasted withdrawals vs. actual invintory and cxplanation of difference. 


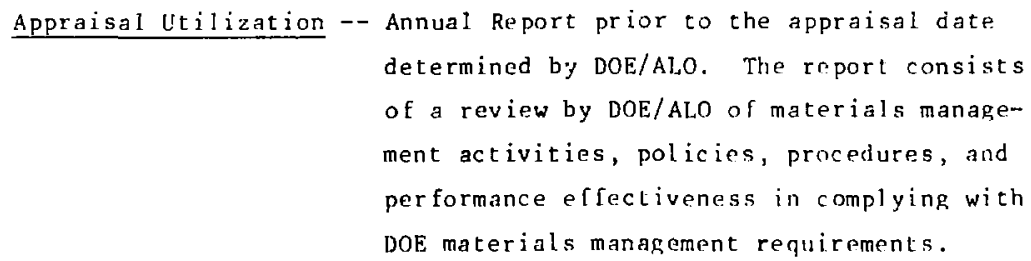




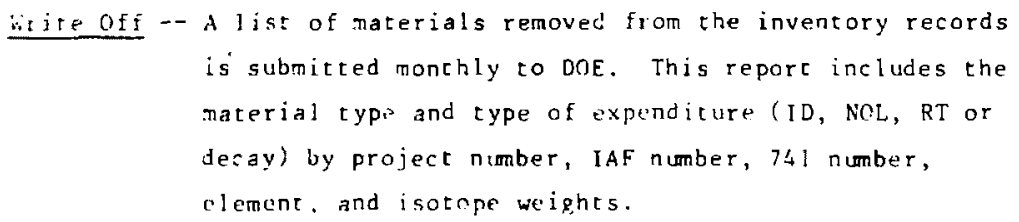

TABLE IV-T

Management Reporting Requirements

\begin{tabular}{|c|c|c|}
\hline Report & Erequency of Reporting & Recipient \\
\hline Formcast & Annually in January & DOE/ALO \\
\hline For acast vs. Ac:ual & Quarterly & $\mathrm{DOE} / \mathrm{AIC}$ : \\
\hline$M M P$ & Annually in Mav & $\mathrm{DOF} / \mathrm{AL} \cap$ \\
\hline Astins $\operatorname{chin}^{2} \tan$ & Annually in Noverniser & DOF/AIA \\
\hline Writ. ore & Yonthly & $\mathrm{DOE} / \mathrm{AL}, \mathrm{R}$ \\
\hline
\end{tabular}

\subsection{Internal Computer-Generated Feports}

$A$ number of internal reports and listings are genuraled porindically to assist the Nuclear Materials Manager in the management of Sandia's nuclear material inventory and in the preparation of reports te the Dof. These listings are generatid by soating the computerized accountability racords in various ways to provide information in the most effective format for sacific purposes.

- Scorage Report (by owner MBA)

- Scrap/Excess

- Items Awaiting Remnval

- Material Profile

- Project Number Repore ( ) manth)

- Strategic Area

- Alarm

- Management Summary

- Material Type (total elemenc and isotope weights)

- SNM oy MBA Report (for healrh physics) 
CHAPTER $V$

CONTROL

\section{Responsibilities}

The physical control of nuclear materials requires continuous survoillance from the time of initial receipt to the time of eventual di-position to ansure proper utilization and safeguards control of rilorlals, pruvide a afe and secure movement of materials, and maintain ar wrat accountability records. Because of the intrinsic value of hul l.a: malerials, special consideration must be given to the prompt idfutification and timely processing of recoverable scrap and excosa malrigls. The Nuclear and Explosives Materials Control Section asamis prinary risponsibility for the physical control of nuclear materials in thi possossion of Sandia National Laboratories. In fulfilling this responsibjlity, the Nuclear and Explosives Materials Control Section retive, processes, and ships all radioactive and nuclear matirials. controls the physical movement of accountable materials within sandia National laboratories, and provides storage for accountable materials : i ily be 1: for futur use or shipment. Specific responsibilitios ar to:

- revile radioactive and nuclear materials.

- inish all materials (if appropriate) or (for Category I quantitirs of SNM) verify the presence of nuclear material by nondestructive assay methods upon receipl or prior to shipment.

- Concacl suppliers regarding shipper-receiver we ight differences or other discrepancies noted in materials received. 
- Assign material descriptors to materials received or modified, when not found etched on material or referenced on the accompanying paperwork.

- Prepara nuclear matelials recoiving slips.

- Forward completed packages of receiving or shipping paperwork to the Safeguards and Technical Security Division.

- Prepare transfer documents for materials being issuid to using organizations.

- Arrangr with the Transportation Division, the Health Physics Division, and for the Safeguards and Security nepartment (as necessary) for the physical transfer of materials between requesting/using organizations.

- Maintain processing a:d storage areas in Building 819 and at Manzano Base for accountable nuclear materials received, held for future use, or awaiting shipment.

- Verify the presence of nuclear material in all items containing Category I quantities of SNM which are being transferred from custodians for storage and (if appropriatel place verified materials in containers with tamper-indicating seals applied.

- Maintain records of tamper-indicating seal and container numbers along with the date applied.

- Provide identification tags for accounlable materials received or being held in storage. 
- Prepare packing slifs for radioactive and nuclear naterials being shipped.

- Yonitor the radioactivity of materials being shiphird.

- Observe all criticality, safety, and security regulations pertaining to the hand ing and shippine of radioactive and nuclear matria!s.

- Arrange for the packering of radioactive and nuclear materials seing shippred.

- Packagr SNM being shipprd as well as scrap and exerss materials hejne shipped for recovery.

- Prepari burial forms and arrange for the burial of scrap.

- Assist ciatodians in the weapon systems (Building R09) and the reactor arca (Area $V$ ) in physically controlling accountable nuclear naterials, in preparing required paperwork, and in maintaining appropriate records.

Figure $V-l$ includes a sumary of the activities of the Nuclear and Explosives Materials Control Section, published by the Salary Administration and Position Evaluation Division. 


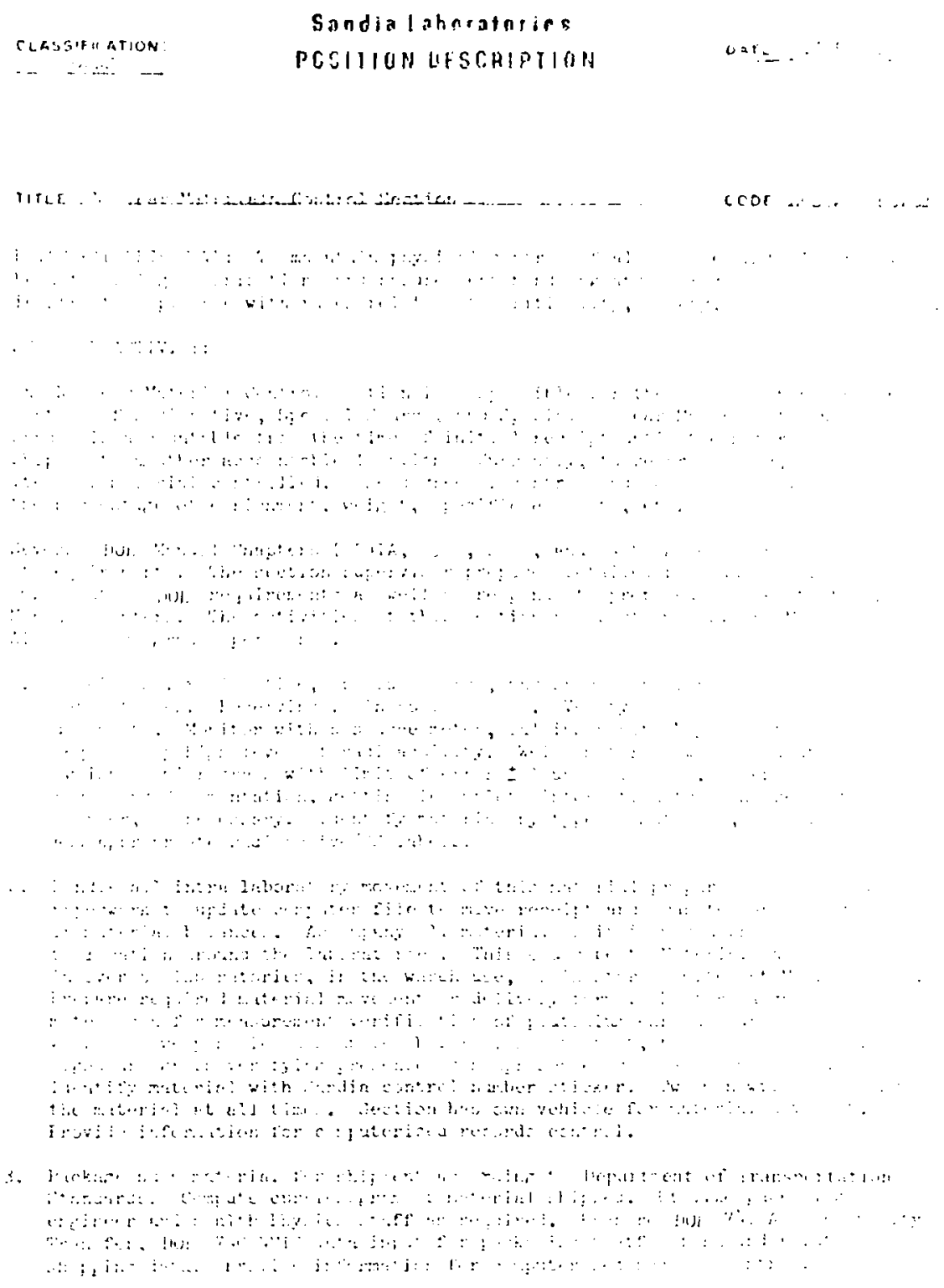

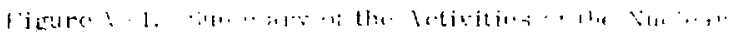




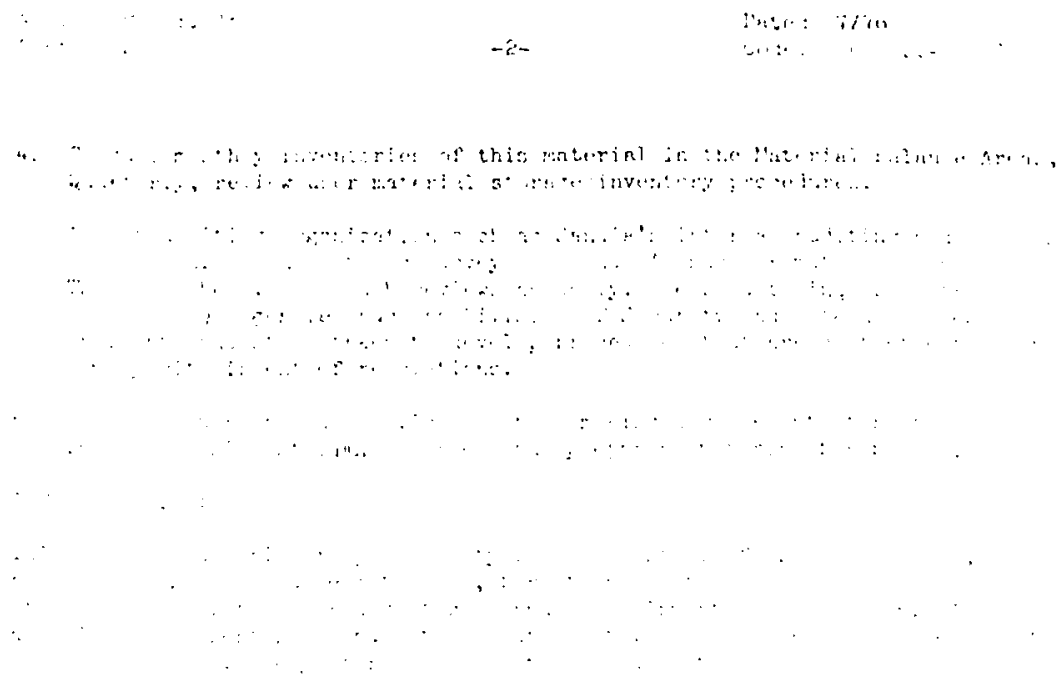

$1 i \cdot 1 \cdot 1-i+1, \ldots: t$ 
2. Job Descriptions

The activities of the Nuclear and Explosives Materials Control Section are performed by one Management Aide along with siviral graded : reinniel. lob dracriptions for thres posicions arf published by the Job ilassification Division and retained by the Nuclear and Explosives "ateral control Section and the Job Classificiation Division in their foles. Fiuure $V-2$ provides the published description for the Nuclear Yat.: : : antral Ass atant, and Figuri V-3 provides the comparablo les rintion for the NM Control Continators. 


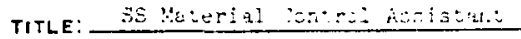

runCTEN :

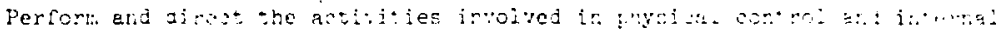

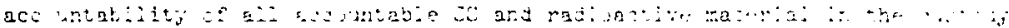

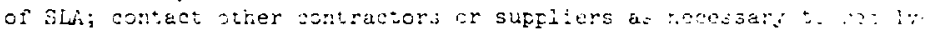

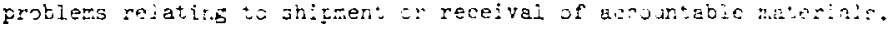

DUTIES ATد MU FOHSIBIZIILS:

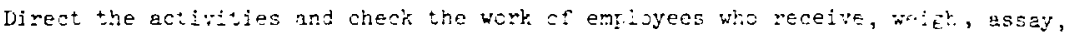

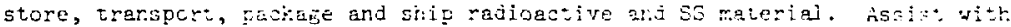

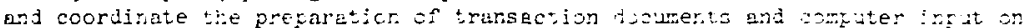

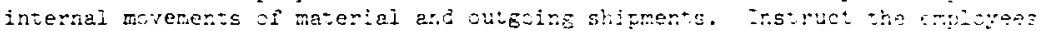

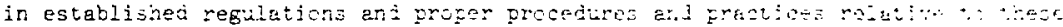

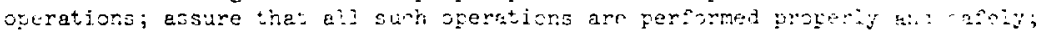
and assist with the sctivities as necerary.

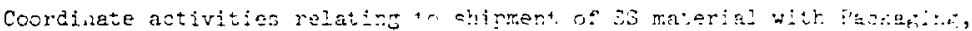

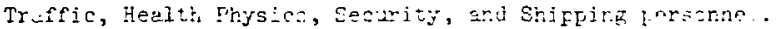

Resolve probiems conceming matters such as machining operation, exp.t.

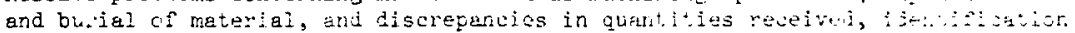

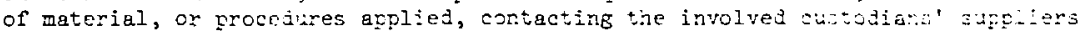
as necessary.

Assure that materiai assigned to each custodian is packaes, strei, sr..

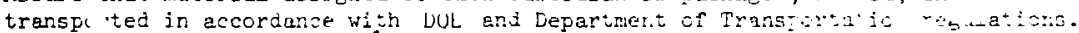

Troubleshoot problems reiating to incoming shipments of reterias. is: is ar

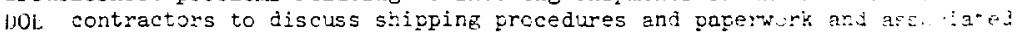
problems with a view to possible improvemerts. Prepare triI repomts dit memoranda setting forth findings ani recommenti:ions.

Firure V-2, .lob Description for the SS Naterial Control Asistant 


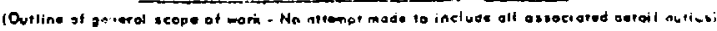

OCCUPATION TITLE: CONTROL COORDINATOR (SS and RA Materiais)

GRADE 7

JOB FUNCTION: Working from verbal and written instructions, per:0:л varit:- operati.:2 associated with the physical control of radioactive ani special nuolear $\pi$ iteriul.

REPRESENTATIVE PRODUCTS, MATERIALS AND PROCESSES: PRODUCTS: Variety of stora $\mathrm{e}$ and

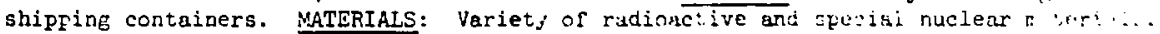
PROCESSES: Receiving, identirying, storint, moving, shipping, weighing, measis.'int,

REPRESENT ATIVE MACHINES, EQUIPMENT, TOOLS AND GAUGES USED:

Yoland precision balance

Standardized assa; meter

Top load baiance

Camma survey -oters, Alpha survey meters, iieutror. survey deters

Coleulator

Forklift (ut to j000 pounds), Light motor vehicle

Electric hoist

Compiter ierianal

Band ject

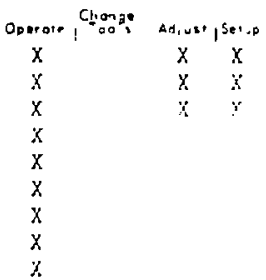

TOLERANCES Requires special ability and practice tc operate precisicr. Giaris: . tolerances wich are not particularly difficult.

SOURCE AND TYPE OF JOE INFORMATION: Grazieno Tariff, hazardcus :ateria:s tepart:ent

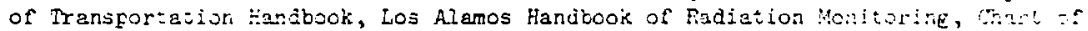
Nuclides, basic Fad:olcéical Health Handbook, Isotope License File, verbul uad written instructicns.

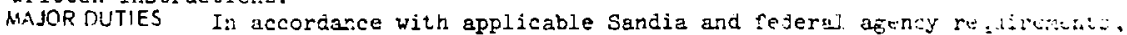
receive, identity, store, assign material serigl numbers where reguirej, $n:$ rove radionctive und special nuclear meterials; make precision weight measuress:ts ir.t input dita obtained for computer verification of ceasurenent accuracy; ar. ievonteninate containers using various cleaning soluticns. Initiate special st.ppi:le

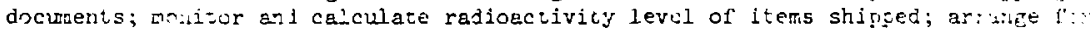
appropiate containers for shipment; and assure that all procedires relati:l: :j

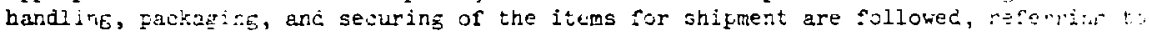

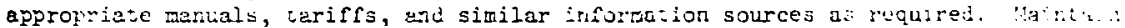

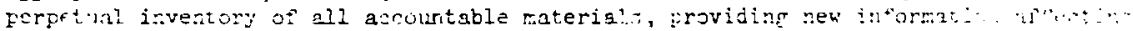

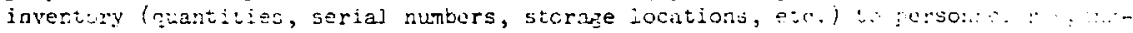
ible for control recorcs. Assist in periodic sudits of accountabil materit. i: $: E$ custody of Haterial Balance Areg Custodians. Participate in the mndestrus:ive asiay or items received to a er ain presence or absence of fissionablp materiaj: an! $: 50$ of such materials involved by operating specialized monitoring equipment ... graphic plots of instrument readirgs. Perfurn reluted duties involving similat skill and responsibility.

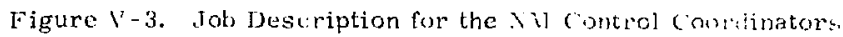


i. (onl in) illowist:

$\therefore$ Anure tad. adequate control and proper accountability of nuclear matelals are exircised at all times, Sandia Laboratories maintains a

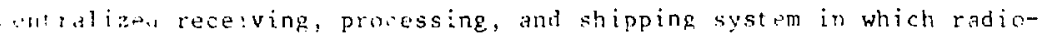

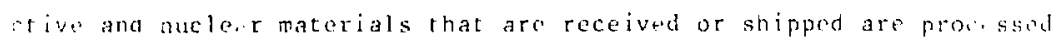

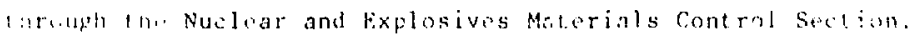

Figura Jll-s in Chapter IIT illustrates a simplified flowehart for th. physical disposition of the nuclear materials utilized in Sandia proframs. As indicated in that figure, the Nuclrar and Explosives Mato... :ials cintrol Section acts as an intermediary in all nuclear matrial I rastations involving using organizations, including receiptr. inturnal Iran-l.r.t. and shipmonts,

Fianre v-4 iliustrales a simplified flowchact for the control resoris :hat ace mpany nuclear materia' tronsactions. Fundamental to the recordkorping system is the Nuclear and Ravioactive Macrital Transfor document wh th acompanies all transfers of nuclear materials betwen MBA's invlidine thuse to or from the Nuclear and Explosives Haterials controi

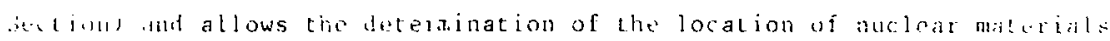
31 il! 1 iाn. 


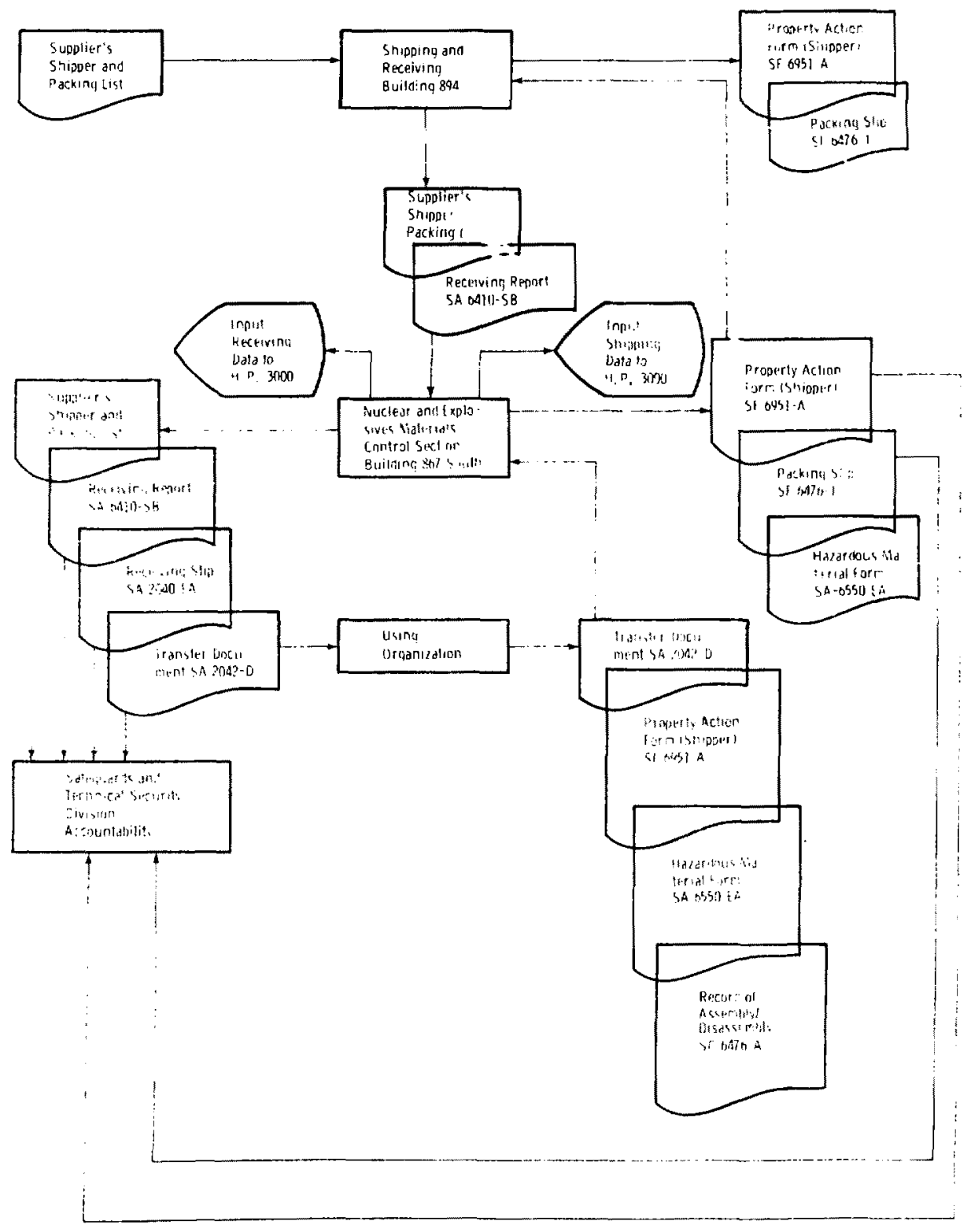

Figure V-4. Sinplified Flowchart for Niclear "atcrial Control Records 


\section{Receipts}

The physical control of radioactive and nuclear materials is supported by, centralized receiving system in which all radioactive and nuclear materials received are processed through the Nuclear and Explosives Materials Control Section prior to being transferred to using organizations. In addition, all receiving paperwork (including that for 1.xplosives received in the Igioo Area) is prncessed through the Nuclear and Explosives Materials Control Section. This system provides for tho verification of material quantities, permits any necessary resolution if liscrepancies in shipping information, and ensures thint records of all nuclear maletials enter the computerized accountability system.

\section{Procedures for the Receipt of Radioactive and Nuclear Materials}

Responsible Organization

Shipping and Receiving Division
Action

1. Receives materials (except those containing. Category I or II quanm tities of SNM) in Building 894 and prepares a receiving report on either Form SA 64:0-SB, "Material Receiving Report" (Exhibit 5, Chapter VIII) or on Form SA $6410-$ SC, "Material Variref Receiving Report" (Exhibit 6, Chapter VIII).

L. I Materials containing Category I or I I quantitios of SNM are couriered directly to Building 819.

1.2 Form SA 6410-SB is prepared for receipts which can be referenced by a purchase order number, and Form SA 6410-SC is prepared otherwise.

2. Notifies the Nuclear and Explosives Materials Control section of the receipt of the materials. 


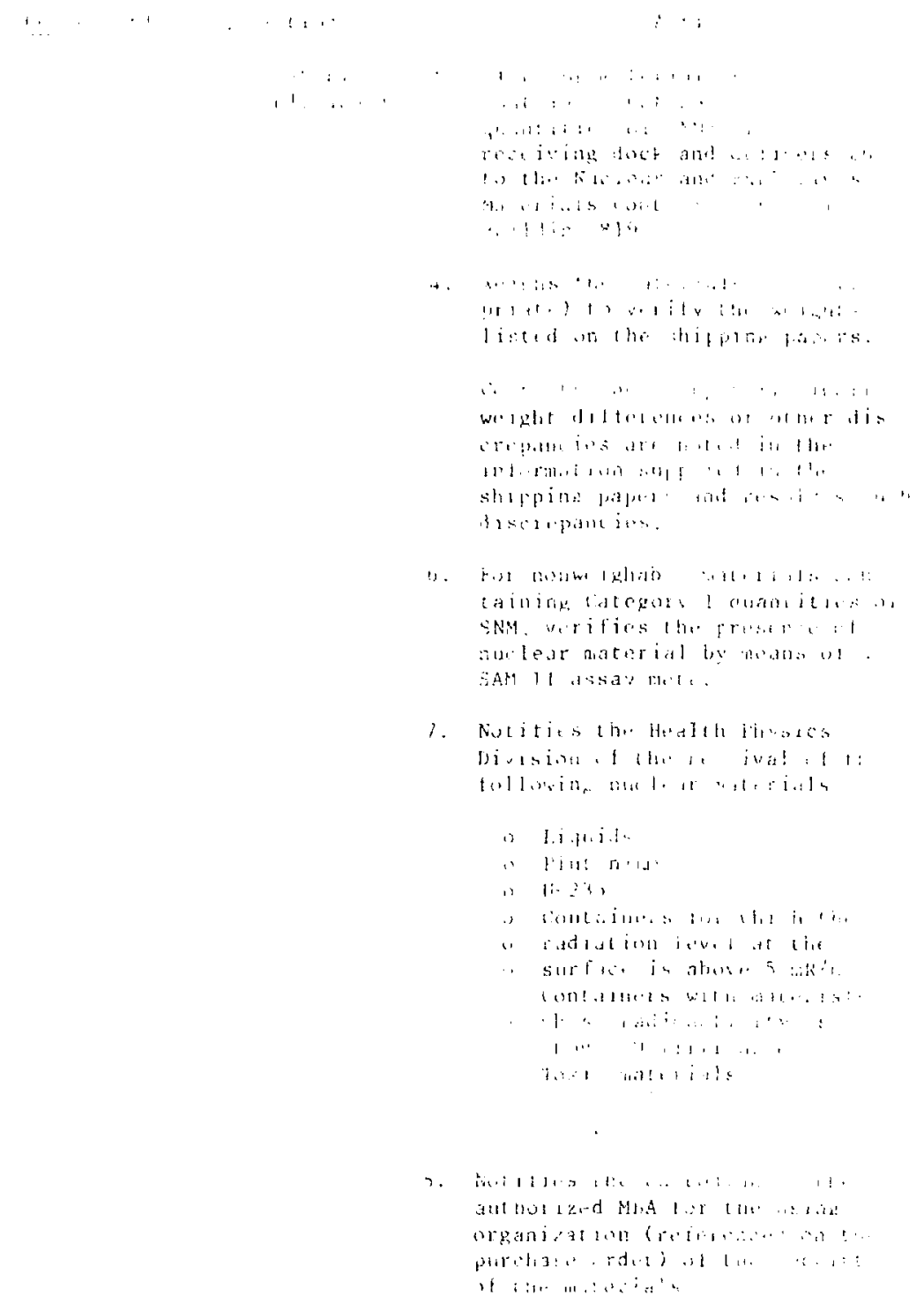




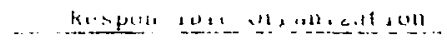

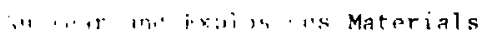

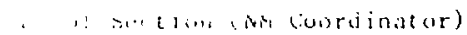

ivaslua and reptosives Matorials control sietion (ay foordindtar)

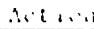

9. Consults the custodian of the authorizod MBA about the aseignasut of rexisting dest bptors lo fit within a 15-characior told.

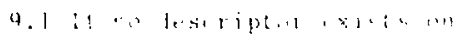

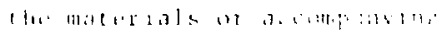

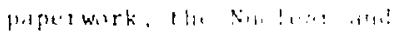

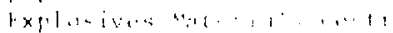
Sir: $1,1,11,1581,114,11$.

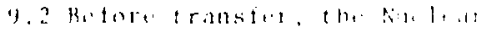
and Explusives Mal a iale

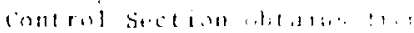

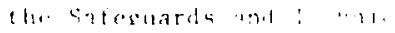

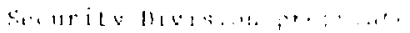

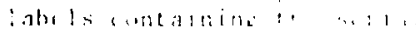

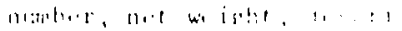
por, meterial l spe, at, a : : tion, and h.l. , i.le ... r i.

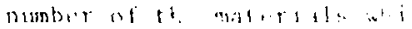

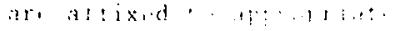

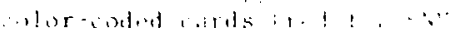

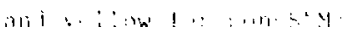

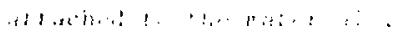

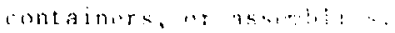

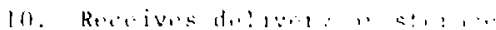

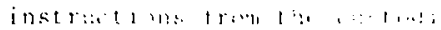
the and hor ind ats.

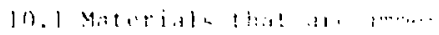

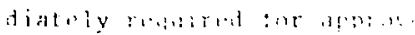

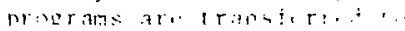

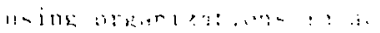

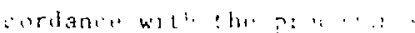
se: furth : : :? 1 : ? : ;

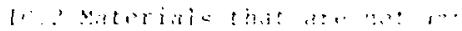

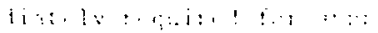

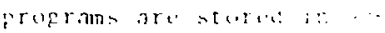

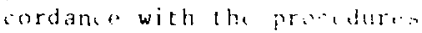
set forth in $S_{e}: 1,0$ t. . .

1. In the semputer terminal, thent:-

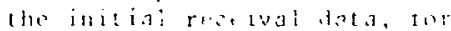

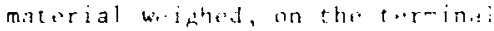

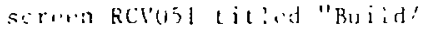
lisplay Recoipt Coorterol)" in accordance with the nuelear llat, riais computer user's guide. 
11.1 For norweighabla material, holds receiving paperwork and checks with ti:t aerountability clerk in the Safrguards and Technical Security Division for 74 data before anterime int the RCVOS] s.teint.

12. Prepares a recoiving slip on F.rin SA 2n40-FA, "Rad inact ive and Nuclear Materials Rec.iv ng slip" Exhihit 7, Chaptrer VIt . listing all descriptors of mater als and containers.

12.1 is soon as lifacticable, the wy conreinatur handearries the original copy of the nuclear materials receivine slip along with i wo copios a $E$ the rectivina report and on: copy of the shipping papers to : h. accountability clerk in th.. Safepuards and Technical Seoril i Division and forwards, ", inper the nuclear materiale recriving slif to the. Shipping and Receiving Division.

Satezuards and Technical Security Divisinn 1 A: antability (lork)
13. Completes and distributes the incoming form DOF-74l transfer accountability document and inputs data to the computir via Lerminal screen, titled "Initial ReceiptStep 1," in accordance with the nuclear materials computer user's guide.

-...porary storage is provided for rajioactive and nuclear materials : : : $A$ ! iy received. Section 6.1 includes the procedures set forth for ris: Eenporary storage. 


\section{Internal Transfers}

Stringent requirements hav: been established for the safety and security of nuclear materials. To ensure that adequate coritrol and proper acountabitity of nuclear materjals are being exercised at all times, internal transiers and physical movements of materials are made only to approved custodians in authorjzed material balanco areas (MBAs). Internal transfors ociur bhenever:

- Materials are transferred from the Nuclear and Explosive Matorials Control Section to using organizations.

NOTE: For the following materials, approval must be obtained from the Health Physics Division befort thi y may be issued.

- Liquids

- Plutoniun

- 23511

- Containers for which the radiation level at the surface is above $5 \mathrm{mR} / \mathrm{h}$.

- Containers with materials whose radioactivity is above 10 millicuries

- Toxic materials

- Powders (oxides)

- Materials are transferred from the using "reanization to the Nuclear and Explosive Materials Control Section for storape, machining, or shipment.

NoTE: Materials for storape must have a completed form SA 6476-ND, "Nuclear Materials Storage Justification" (Exhibit $] 0$, Chapter $X$ ), at ached to the transfer document.

- Materials are transferred directly between MBAs. 


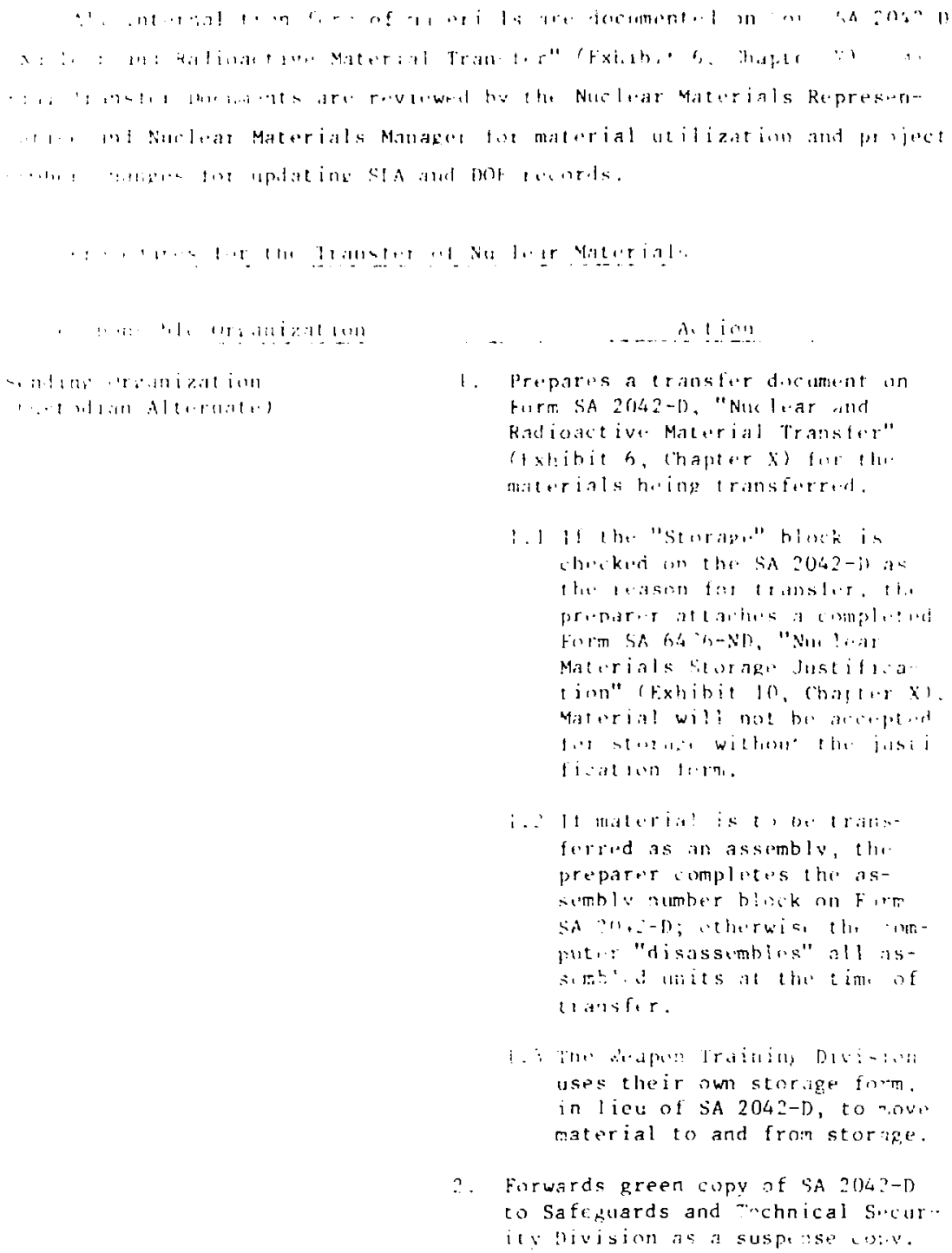




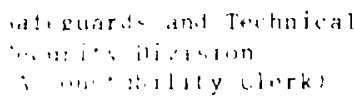

V.J, 1, 3t and Fixplanives Matrial Coneral bietion $\because \quad, \cdots r+101,1, r^{-1}$
3. Phones the nuclear material accountability clork, 844-7! in, t. provide the information requl : :e. (a) complete form Sil hith-Ne. "T: (bisil: $: 2$.

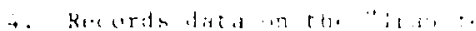

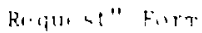

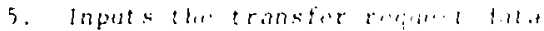

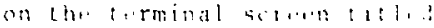

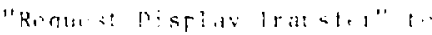

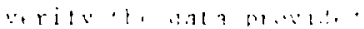

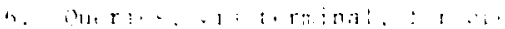
transicers.

h. I I spen ial instru. 1 i ms :

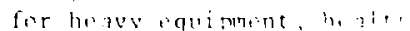
peqsin partialation. A : e

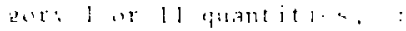

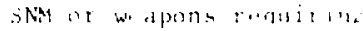

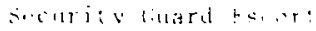

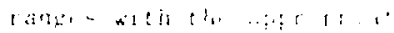
persimat tor montment this Taldr $r|a|$.

i. When ready to playsliall: , , material, inputs data lo th

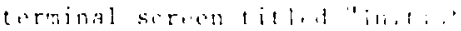
Transfor."

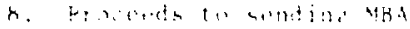

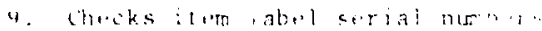
arainse those recordtel in tha transior downent.

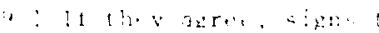

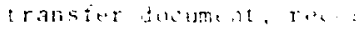
ing date and time.

0.2 If they disagrer. regaterts custodian to carrect thr transfor document, then signs and records date and time on the corrected decument. 
10. Clves the enlaringed coips of $\mathrm{th}$. transfor document to the :usto-

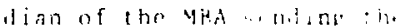
matirial.

Sindlup lrianjoation (astodian alternatr)

Nu l. and Explosives Yat lat: lintrol sinction

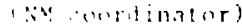

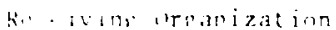

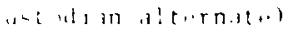

$\because \quad$. : mis lantinives

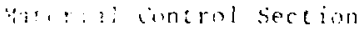
$\because$, a : inator)
11. Rutains the galdertrial crpe to r.lideve the sending vBA of ueountabilits.

l? Movec the material, with the whi! r, yellow, and pink opies af the transfer doinent, to the le ivini Yha.

13. Checks the materaid to ensure that the transier loilment accurale! roflerts the material label serial numberis.

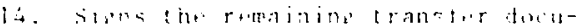
me nt aples, r+erting date and

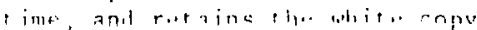

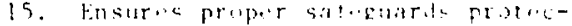
tion for the materialt.

16. Delivers the pint pu it the transfer dosument tis the Saleguards and Technica! Serurit: Division.

17. Retains the yollow ary if the transfer document ant fijes in the Nuclear and Explastes Vatrol Control Section ifict. 


\section{Storage}

Thir Nuclear and Explosives Materials Control Section assumes primary rosponsibiaity fis the cemporary storage of radioactive and nuclear mate-

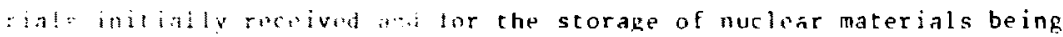
tu. lit for futurt use in approved programs or awaiting final disposition instructions from the DOE. These materials are stored in designated areas ㄷ kuilding 819 and in storage structures lorated at Manzano Base. Mll materials are strred in accordance with strinpent safety and spcurity rirujrements, as described in Chapter VJI; accountable materials for "Craraz" mist br accompanied by Form SA 6476-ND, "Nuclear Materiaic itorage Justification", approved at the appropriate supervisory level des nated $\therefore$ tr.. furm for the storage time requested.

\section{h.: preceiners for the Storage of Nuclear Materials Initially ieceived}

Sectinn 4.1 af this chapter includes the procedures set, rth for the rexint oi nucienr matarials.

\section{Responsible Organization}

Nuclear and Explosives Materials Control Section (aM coordinatin)

\section{Action}

1. Checks the nuclear terjals justification form for proval level and verifies that the appropriate identification tag wit' the serial number assigned is atcached to the materials.

1.1 Tags are cn r-coded according to the typ. of material as follows :

Red - SNM

Yellow -.- SS material

White --- Radioactive material (used in storage only for nonreportable materials)

Gre'n -.- Negligible quantity accountable materials 
Rasiponsible lrganiantion

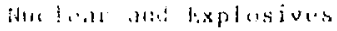
Mat in ial: lind a d Sect ion

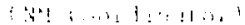

-

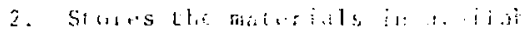

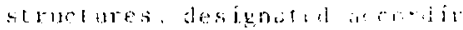

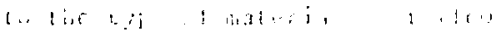

SNM Sroucture fobs at Manazno lante

SMM Structure 7055 il Marand las. Bulding 319

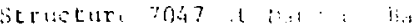

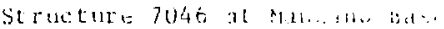

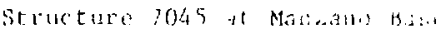

¿. I I apprapilat, wain, iaj a

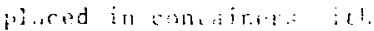
Lamper-indicating seals applied, and records ar matutaines at the rial sir.i containter number alowe wi:! thr dal appied.

2.2 Special safeguards reguira ments regarding, acriss to : etructures at Manzanc base ia included in Section 6 , Chapter VT .

3. Records the storage and bin location on the nitclear inat rit: receiving stip whioli is latel a on Form SA 2040-5A, "Rallina, live. and Nucleal Marerjals Recriving s!jp" (Exlibil ?, tiajte' "ij!

3.1 The corpleted nuclear materials receiving stip, , forwedid acconding th $1 \mathrm{~h}$. procedures specified in section 4.1 .

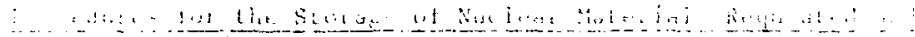

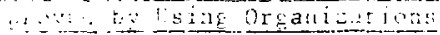

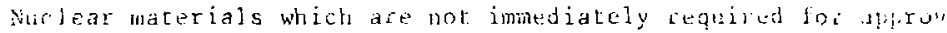
1:ogrims aro transferred to the Nuclear and Fxplosjues Materials Conti suetioll to be held in storage tor ruture use. lising organizations are

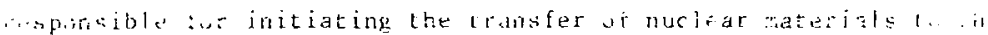

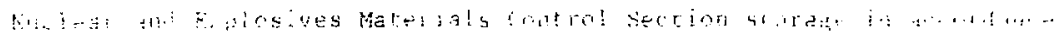

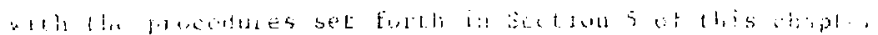


Responsible Orgarization

Jsing Organization
Nive idar and Explosives

Ya:?ri: : \& Control Section

(Nat cosirtinator)
Action

1. Prepares a transfer document in accordance with the procedures set Forth in Section 5.1.

1.1 The transfer document must be accompanied by a nuclear materials storage justification, Form SA 6476-ND (Exhibit 10, Chapter $X$ ), which authorizes retention period for the materials and the program for which the materi ${ }^{\prime}$ ls are being held.

2. Turns in the ruterials to the Nuclear and Explosives Materials Control Section in accordance with the procedures set forth in Section 5.4 .

3. Upon receipt of the materials, verifies that the appropriate identification tag with the serial number is atcached to the materials.
3.1 Tags are celor-coded according to the type of material as follows:
Red --- SNM
Yellow -- Non-SMM material
Green - Neg. Qty. nuclear material
White -- Radioactive

4. Stores the materials in available structures, designated according to the type of material as Eol lows :

SNM Structure $706 j$ at Manzano Base
SNM Structure 7055 at Manzano Base
Building 819
Structure 7047 at Manzano Base
Structure 7046 at Manzano Base
Structure 7045 at Manzano Base 
Responsibie organization

Nuclear and Explosives Materials Control Section (NM Coordinator)

\section{Action}

4.1 If appropriale, materials are placed in containers with tamper-indicating seals applied.

4.2 Sealed container information is input to the computer on the terminal screen titled "Apply Seal-Initiate" which rrcords each item sarial number contained and generates an identification label for the container for inventory.

4. I Special safeguards requirem ments regurding access to the structures at Manzano Base are included in section 5 , Chapter VII.

"'sing organizations may withdraw nuclear materials from storage by L.: : phining tise Nuclear and Explosives Materials Control Sretion with the seriai numbers of material requested. Upon receipt of this call, tha Nuilear and Explosives Materials Control Section transfers the materials to the using organization in accordance with the procedures set forth in Section 5 of this chapter.

Stnrage Reports will be generated monthly showing those itams with expired retontion dates which will be investigaced for rejustifiration of storage extention nr declared excess. 


\section{Shipments}

To ensure strict compliance with DOE and Department of Transportation regulations, all radioactive and nuclear materials requiring shipment oif site are processed through the Nuclear and Explosives Materials Control Sectica. In addition, all shipping paperwork is processed through the same organization. StI 6950-2, "Shipments," provides guidelines for the shipment of these materials, and SLI 6950-4, "Movement of Classified Material," provides supplementary information in the case of classified materials. In addition, shipments of scrap and excess materials for recovery and shipments to Rocky flats or to the DOD require upecial procedures to be followed.

Handearried materials require the samo paporwork to be processed through the Nuclear and Explosives Materials Control Section and through the Packaging Engineer as for ordinary shipment. This is necessary in order to ensure compliance with DUE and DOT regulations, including the Eo: lowing:

- Radioactive inaterials camnot be handcarried on passengercarrying aircraft.

- Radioactive materials cannot be carried or transpotted in personal venicles; only government vehicles can be? uhard for this purpose.

If shipment is going to a company or institution other than a license axempt DOE contractor, the organization responsible for shipment must obtain a copy of the recipients license prior to shipment if the Nuclear and ixplosives Materials Control Section does not have a current copy in file. 


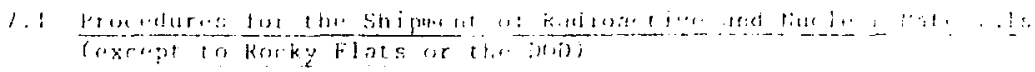

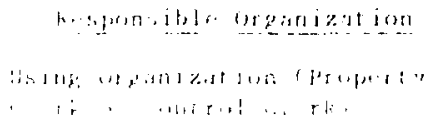

i'sin! irganization (iroperty liark or contal C!. rkj

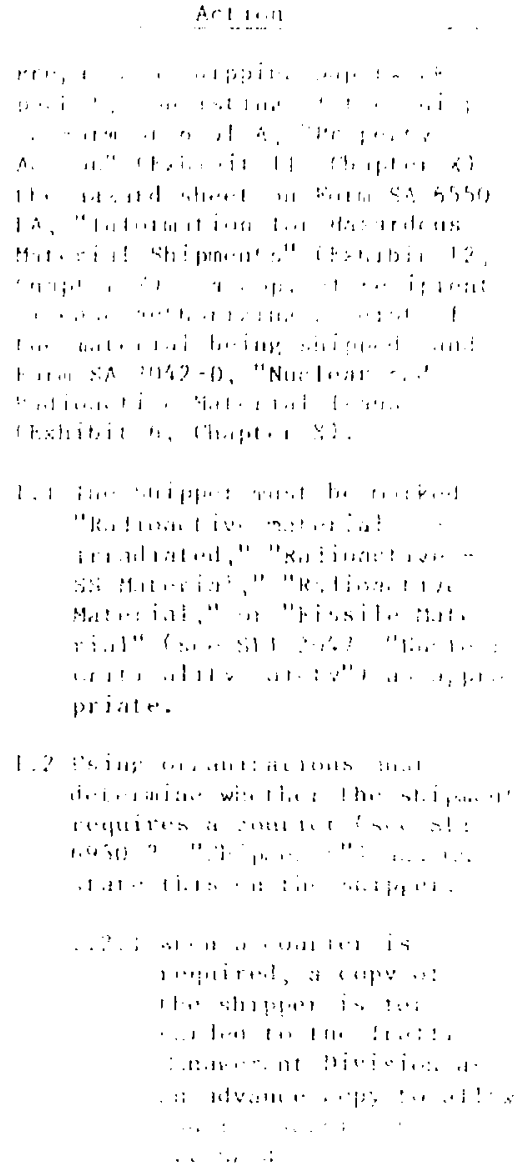




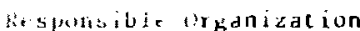

$\because 1$, is al inde fixplosive's प.7.

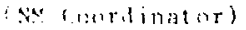

Action

2. Transfers the materials and paperwork to MBA Ol lassigned to the Nuclear and Explosives Materials Control Section) in accordance with the procedures set forth in Section 5 of this chapter.

3. Prepares a packing slip on Form SF 6476-I, "SS/Radioactive Material Packing Slip" (Exhibit 8, Chapter VIII), based on the inrnrmation contained in the shipping paperwork packet and the master file.

3.1 Distribution of the five copies of the packing slip is as follows:

Original -- Accompanies materials

2nd copy -- Sent to the Health Physics Division

3rd copy -- Sent to the Packaging Section

4th copy -- Returned to the Nuclear and Explosives Materials Control Section at the time of shipment

5th copy -- Retained by the Nuclear and Explosives Materials Control Section until the 4 th copy is returned.

4. Enters the level (in curies), material type, and type of radioactivity on the hazard sheat. 
Responsible Organization

Nuclear and Explosives

Materials Control Section

(NM Coordinator)
Shipping and Receiving Division (Packaging Clerk) or Nucleat and Explosives Materials Control Section (for SNM) (NM Coordinator)
Action

5. Inserts Form DOE-740, "AFP Transcription Sheet, Nucla ar Material Transaction Journal" (Exhibit 9, Chapter VITJ), after rentering ihe RIS and transaction number, into the shipping paper-work packet to be forwarded to the Packateing section.

5. I Retains shipping packet ensisting of Prupurty Aclion Form SE 6951-A. 2nd copy packing slip Forn SF 6\&76-1 - 4th a upy Transfir form SA $2042-1$ ) 2nd \& 5 th iapios.

5.2 Prepares and rolivers an accountability shipping packet to tion salenuards and Trehnical Srcurity Division consisting of A copy al Propely Action Furm SF6951-A Assimblyl Disassembly Form SC $5476-A$ Transfer Form SA 2042-D ird and $4 \mathrm{Lh}$ copy.

5. 3 Prepares shipping poikne consisting of preperty Action Form SF 6951-A Ist, 2nd $S 4$ th copy llazarit Shert Form 6550-EA Packing slip Form SF-6476-1 Ist, 2nd, 3 rd \& 4 th copy Criticality Evaluation statrmenc (on ii! l shipments containing fissile materials) Fors Mi, -740 .

6. Physically moves non-SNy materials and the shipping paperwork packet to the Packaging Section in accordance with the procedures set forth in Secrion 5 of this chapter.

7. Packages the materials in accordance with DCE and DOT regulations, enclosing the green copy of the shipper and the packing slip. 
Health Physics Divisinn

(Health Physicist)

Shipping and Receiving Division (Packaging Engineer)

Tralfic Management Division (Traffic Clerk)
7.1 SNM is packaged by the vuclear and Explosives Material; Control section in specificationtype containers ! o comply ,ith criticality requirements (as specifiod in SLI 2047), and security seals aro applied.

8. Entors the packaging information (container, weight, etc.) on the Form DOt-740 and shipper's ixport derlaration when shipment is made to a foreign recipiont.

9. Contacts tho Health Physics division for inspretion of the pockaged matorials of radinact ive materials.

10. Monitors the radiation l, ....

(in $\mathrm{mR} / \mathrm{h}$ ) at the surlacis of the packaged materials.

11. Verifies that the correct radioactive labeling has been at tached.

12. Enters the transport index and other required data on thr packing slip, signs, and retains one copy.

13. Forwards the shipping packot to the Traffic Management Division.

13. I Arranges for transporiation of nuclear materials to Kirtl and AFB West when shipped from Arcia 1.

14. Reviews the packaged materials and shipping paperwork to dotermine the method of shipment needed to comply with DOE and DOT regulation".

15. Enters the transportation information on the Form DOE -740 . 
Responsible organjzation

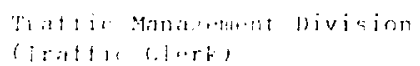

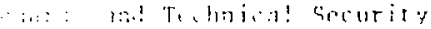

. .

$\therefore 1$ :
Action

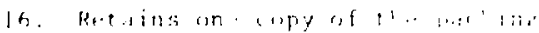
si i i.

17. Arranges appreptad, arta sorvica 1.)r thi shipanotil.

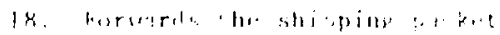

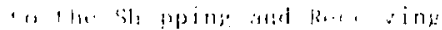
divicinn.

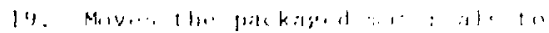

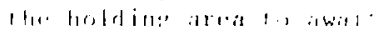
1. hipminllit.

?). lapun sbipment, not i li, s the

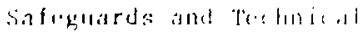
Sircurity Division of 1 li.. shipment of I he Materials.

20. I llpon stipmont from tho.

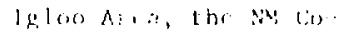
redinatur not ilins the Shippins: and Rereriuin. Division clark and ia : .guards and Trelanilia Security livisiom ac countability cliark by telephome immodiatoly following shiparat.

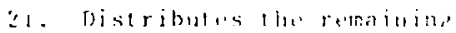
sinipping paperwurk.

21. 1 Thr safuguards and Trobal:(al security Division picks up the papen wiork 1, [a listributw? to l he. Nuclear and Explosives Moterials Contro: Sietim

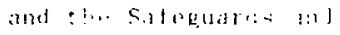

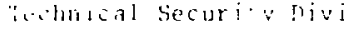
sion and handcarries it to those organizations. 
22. Provides by TWX to the NMR of the Receiving Contractor, on shipments of special nuclear material totaling more than 350 grams of contained $\mathrm{U}-235, \mathrm{U}-233$, plutonium, or any combination thereof, or I gram of tritium, the following information:

- Date and $t$ ime of departure

- Method of transfortation

- Route

- Name(s) of carrier(s)

- Estimated time of arrival (ETA)

- Sandia shipper number

- Nucliar Material Transaction Report Series Number (DOF Form 741)

- Tine Number

- Project Number

- Material Type

- Composition corro

- Owner code

- Use Code

- Number of Items

- Element Weight

- Weight $\%$ Isotope

- Isotope We ight

23. Completes and distributes the outgoing Form DOE-74l transfer accountability document and updates the Sandia and NMMSS computer records. $\therefore \quad i^{2} \quad \therefore$ Hres lor the Shipmane of Radioactive and Nuclear Materials

ii: aldition to the standard paperwork, Rocky Flats renuires form RF-1940. "Authorization to Ship SS or Non-sS Material" (Exlibit I3, Chapter $\therefore$ Lo be forwarted by the using organization to the Nuclear Materials hiprosentative prior to shipment. The Nuclear Materials Representative tir. fpplic: (1) iny nuclear materials as well as to any nonnuclear materials liki hal been exposed to radionuclides (such as fission products, other 
actinides, or tritium). The requirement also applies to any matrials being returned to Rocky flats which have undergone change sind "the. wr.r.

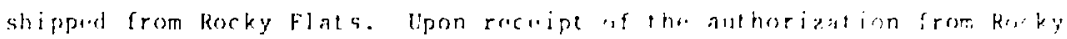
Fats lo shife, shipment of tho materials procureds in arenrdate. with th.

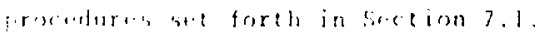

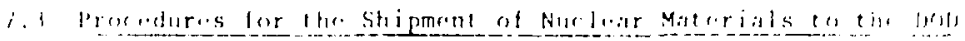

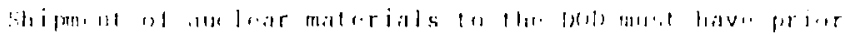

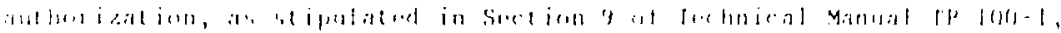

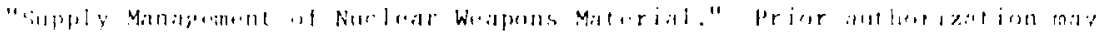

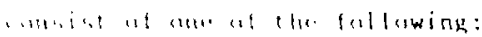

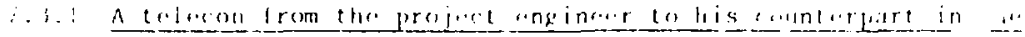

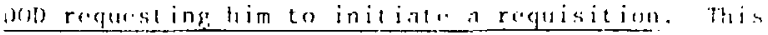

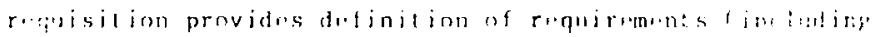

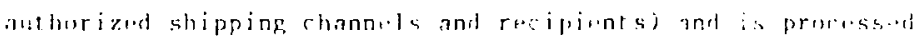

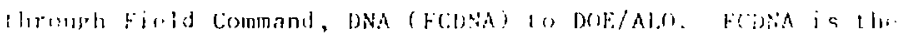

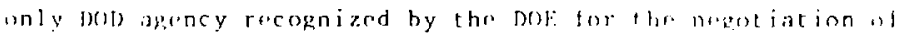

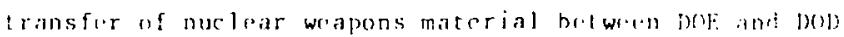
activitits, and fingl negotintions are mads by filsod. The approvind requisition and momorandum from the biepossi Production Division, DOF/ALO, must be receiverl by 1 !

afoguards and Technial Security Division prior lo thipent.

7.3 .2 A letter from the project engineer to the Whapons Production Dilision, DOE/ALO, (with a copy to the Safeguards and Technical Security Division) defining any change in rquirements or supplying any supplementary information needed to support a Memorandum of Understanding, J::int Test Agreement, or Joint Operating Plan. A copy of the reply authorizing shipment must be received by the Safeguards and Technical Security Division prior to shipment.

Upon receipt of the authorization from DOE/ALO, shipnent of the materials proceeds in accordance with the procedures set forth in Section 7.1 . 
$\rightarrow \quad \therefore$ medures for the Shipment of Scrap and Excess Materials for Recovery

Since. •.sts, experiments, and fabrication processes often result in a.ermulations of serap andior ixeses materials, procedures have been -stablished :o tensure that recoverable matcrials are identifird accuratriy, reported promptly, and handed properly to permit disposition and

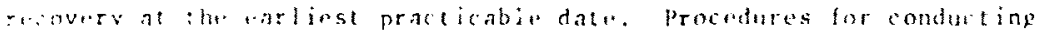
axper ants or pests in which material exproditures and/or scrap or excess ma! rerials are anticepated are included in section 7, Chaper liv and

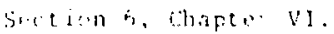

foldowing tosts or fabrication processus in which serap and/or excess raterials are generater, the using organization transfers these materials 1. Lia Guelwar and Explosives Materials Control Section along with o aemeranders declaring the materials to be scrap or excoss.

\section{Sisporsible freanization}

lising organiantion

Nurlear and Explosives Materials Control Section (NM Coordinator)

\section{Astinn}

1. Transfers the materials to the Nuclear and Explosives Yuterials Control section in accordance with the procedures set forth in section 5.1 alnng wizh a memerandum declaring the macerials lo be serap or excess.

2. Reweighs rach item of material (if appropriate) and compares the weight with that recorded in the computer.

3. For nonwe ighable materials containing significant quantities of SNM, verifics the presence of nurlear material with a SAM-II nondestructive assay meter.

4. Requests disposition instructions for the materials from the Safeguards and Technical Security Division. 


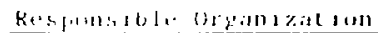

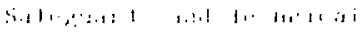
$\therefore 1,1: 1 \because 1 \cdot 1 \% 1, ; 11$

?.', 1., , ,

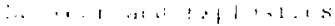

$\because 1, \ldots: \ldots, \cdot \ell_{1}: \cdot 1 \quad \cdots 1 i_{1}$

$\therefore \because 1, \quad: !: \div, 1$,
Artari

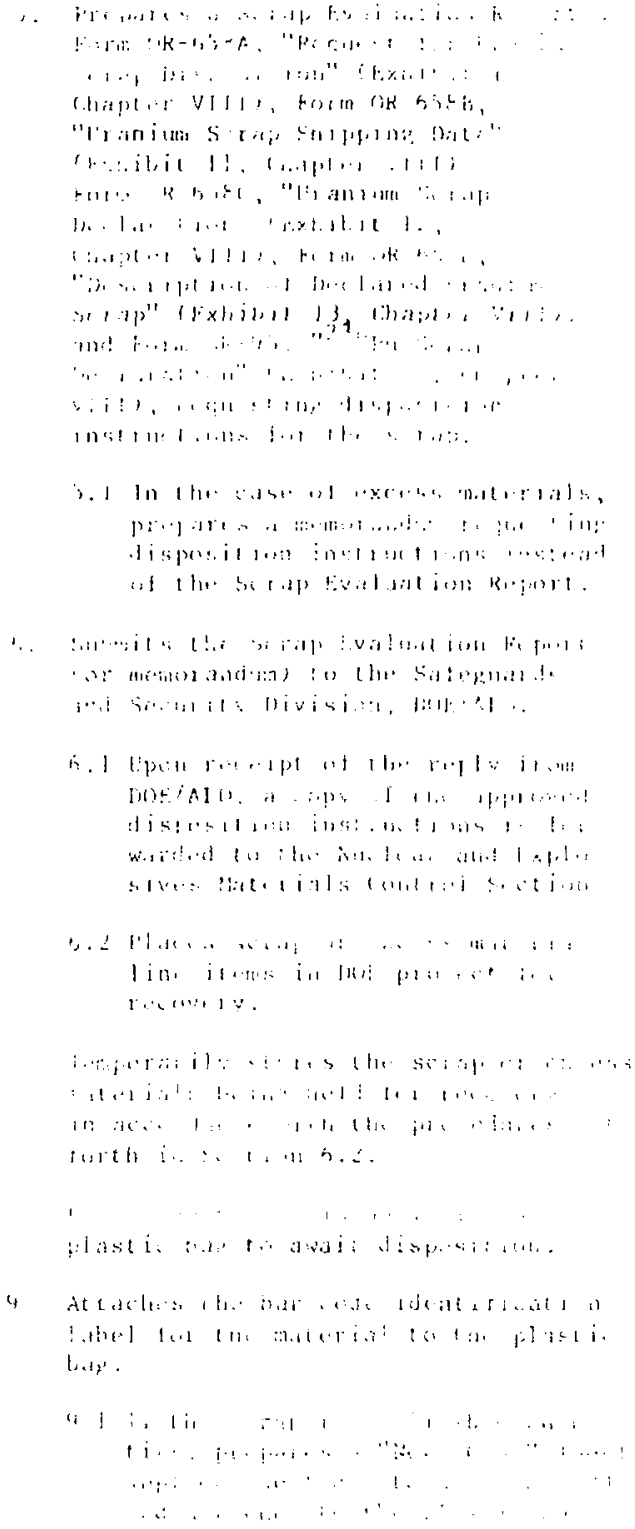


10. Monitors the radiation level at the surface of the materials (in $\mathrm{mR} / \mathrm{h}$ ), which normally determines the recovery plant to which the materials are shipped.

10.1 Materials whose radiation level is $<100 \mathrm{mR} / \mathrm{h}$ are normally shipped to Oak Ridge.

10.2 Materials whose radiation level is $>100 \mathrm{mR} / \mathrm{h}$ are either held or shipped, depending on the disposition instructions received.

11. Packages the materials in shipping containers in accordance with DOE and DOT regulations.

11.1 SNM is packaged by the Nucleal" and Explosives Materials Control Section in specification-type containers to comply with criticality requiraments for shipping (as specified in SLI 2047), and security seals are applied.

11.2 Non-SNM is packaged by the Packaging Section of the Shipping and Receiving Division as specified in Section 7.1.

11.3 All materials are monitored by ine Herlth Physics Division prior to shipment.

12. Upon receipt of disposition instructions, ships the materials in accorance with the procedures set forth in Section 7.1.

12.1 For shipments of Category I quantities of SMM, the Traffic Managemen: Division arranges for courier service with DOE/ALO. 


\section{Scrap}

In view of the value of nuclear matrerials, the pof has established a scrap nuclear material disposition program to ensure that scrap containing recoverable nuclear material is processed in a timroly and aconomical Inanner. DOrie Order 5630, which sets forth thr procrdures to implement this program, states:

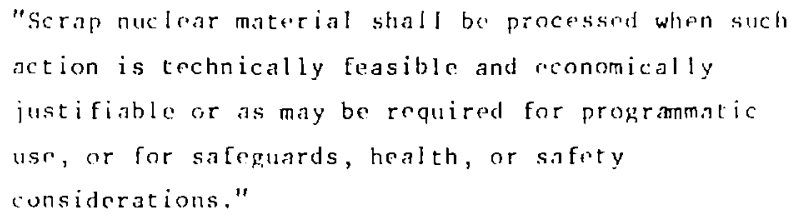

Sucturn 7, Chapter IV of this manual inclides the procedures for the manaement of scrap and texcess materials; this siection includes the correspunding procrdures for the physical control of thrsemiterials.

\section{S.! Procedures for Machining Operations}

Macnining a at atons are performed on depleted uraniar. in order to

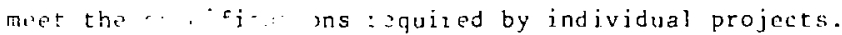

\section{Respons}

tising org
Action

1. Prepares Form SA 6476-ME, "Mcdification/ Expenditure of Nuclear Materials", and sends to Org. 3434 and obtains approval prior to the transfer of the material.

2. Prepares a shop short order on Form SA 6505-WBA, "Prucess and Fabrication Request, Short/Sub Work Order."

\subsection{The work order includes the serial number of each item submitted, along with specifications for machining the item.}

3. Prepares Form SA 2042-D, "SS and Radioacive Material Transfer," Transferring the material to MBA 0l, Bldg. 819 . 
Nuclear and Explosives Materials Control Se.tion (NM Coordinator)

Mechanical Processing De? partment
Nuclear and Explosives Materials Control Section (NM Coordinator)
4. Transfers the material in accordance with section 5 of this chapter.

5. Weighs material and prepares Form SA 2042-D Transferring Macerial to the Toxic Shop, MBA 18, Bldg. 869 in accordance with Section 5 of this chapter.

6. Delive terial to the Toxic Shop.

7. Performs the required macl ining, treating each serially umbered item as an individual job.

8. Upon completion of each individual job, places the finished part or parts in a plastic bag.

9. PIaces the scrap generated in : scparate plastic bag, labeling it as scrap derived from the orional serially numbered iter..

\subsection{Scrap from cach compinted jo must be placed in separate pi... i bags, and not coningled.}

10. Prepares a transfer coument to return the finished part, excess materiel, and scrap to the Nuclear and Explosives Materials Control Section in accordance with section 5 of this hapter.

10.] The original serial number wi!l be used to return the material and the transfer form will be noted as to final configuration of the material, "one finish: : part," "one pc excess," "on. bag scrap," etc.

11. Weighs each finished part 15 well as the sirap.

12. Prepares Form S4 2042-DA, "Nuclear Materials Machining Report", which provides the serial number and net weight of the original item, plus the net weight of each finished part and scrap. 
Responsible Organization

Nuclear and Explosives Materials Control Section (NM Coordinator)

Safeguards and arthadal Becurity Davision (NA Manager)
Sufeguards and Technical Security Division (Accountability Clerk) wheleur and Explosives Maleriais contrul Section (s)l (a) ordinator)
Action,

13. Forwards the Nuclear Materials Machining Report Lo the NM Manager.

1': From data an the machining loport, prepreres lor, SA 6476-NF, "tnventory Adjustenist liorm" (IAF) , at. taches the anachining report and gives to the accountability clerk to adjust the computer records.

1: W. Whes the lal: number on related paperwork and files.

10. Inputs the IAF data inlo the computer on the terminal screen titled

"Perform One to Many", which adjusts the compuler records and generates bar code labels for cach new item, including scrap.

17. Forwards the har code labels to the Nulear and Explosives Materials Control Section.

18. Atraches the serially numbered bar code labels to the appropriate items.

14. Trmporarily stores the scrap in accordance with the procedures sat forth in Section 6.2 until it can be buried.

20. Prepares Forn SA 2042-D, "Nülear and Ralioactive Material Transfer" in accoraance with Section 5 of chis ihapters, to return materials

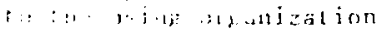

21. Dei inas underial to the atcountulile custodian.

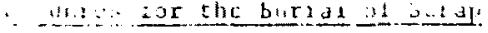

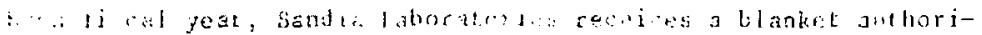

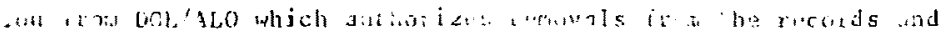

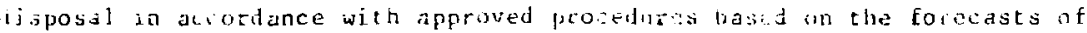


anticipated scrap. Other nuclear materials may also be buried upon receipt of the appropriate disposition instructions from DOE/ALO. The following procedures have been established for the burial of scrap.

Responsible Organization

Nuclear and Explosives Materials Control Section (NM Coordinator)

Safeguards and Technical Security Division (NM Manager)

Nuclear and Explosives Materials Control Section (NM Coordinator)

Health Physics Division (Health Physicists)
Action

1. Prepares Part A of the burial form, Form SC 2040-L, "Radioact te and Toxic Muterial Disposal" (Exhibi 14, Chapter VII I).

1.1 The burial form includes the serial number of the materials, material type and classification, material description (from the computer listing), Form DOE-741 reference number, quantity of material to be buried (in cubic feet and pounds), and total radioactivity (in curies).

2. Forwards the burial form to the afeguards and Technical Security Division for approval.

3. Approves the disposal of the material, signing in Part $C$ of the burial form.

4. Forwards the signed burial copy to the Nuclear and Explosives Material Control Section.

5. Arranges with the Health Physics Division for the pickup and burial of the materials.

\subsection{Health physicists bury materials each Friday or more often, if required.}

6. Buries the materials.

7. Completes Part B (which includes wastes categories) and Part D (which includes the date and location of burial and the signatures of the health physicists responsible for burying and witnessing the burial) of the burial form. 
Responsible Organization

Nuclear and Explosives

Materials Control Section (NM Coordinator)

Safeguards and Technical Security Division

(NM Manager)

Safeguards and Technical Security Division

(Accountability Clark)
Action

8. Forwards the completed burial forms to the NM Manager in the Safeguards and Technical Security Division.

9. Prepares Form SA 6476-NF, "Inventory Adjustment Form" (IAF).

10. Writes the IAF number on a copy of the burial form and files.

11. Attaches a copy of the burial form to the IAF and gives to the accountability clerk.

12. Inputs the IAF data into the computer on the terminal screen titled "Burial", which adjusts the computer records. 


\section{Measurement Control Programs}

To ensure consistent and accurate measurements of nuclear materials, measurement control programs are administered on a continuous basis. Such programs include scale and balance certification as well as the calibra tion of nondestructive assay equiprent.

\section{9.) Certification of Uncontaminated Balances}

The Physical Standarda Division assumes the primary responsibility for calibrating and certifying uncontaminated balances on a semiannual basis. Table $V^{-}$summarizes some of the balances certified by the Physical Standards Division under this program:

$$
\text { Table V-I }
$$

Summary of Balance Certification Program

\begin{tabular}{|c|c|c|c|}
\hline Location & Balance Type & Certification Level & Comments \\
\hline Bldg 819 & Sartorius & $\begin{array}{l} \pm \text { scale division } \\
( \pm 0.01 \mathrm{~g})\end{array}$ & $\begin{array}{l}\text { Meets DOE require- } \\
\text { ment ( } 20-1 \text { imit of } \\
\pm 0.02 \mathrm{~g} \text { for weights } \\
\text { up to } 1500 \mathrm{~g})\end{array}$ \\
\hline Bldg 819 & Digimetric Electronic & $\pm 1 \mathrm{~g}$ up to $25 \mathrm{~g}$ & $\begin{array}{l}\text { Meets DOE require- } \\
\text { ments }( \pm 2 \mathrm{~g} \text { up to } \\
10 \mathrm{~kg} ; 20-1 \text { imit of } \\
\pm 2 \mathrm{~g} \text { above } 10 \mathrm{~kg})\end{array}$ \\
\hline $\begin{array}{l}\text { Area I I I } \\
\text { (Bldg } \\
6630)\end{array}$ & Metcler Top-Loader & & $\begin{array}{l}\text { Certified up to } \\
10 \mathrm{~kg}\end{array}$ \\
\hline
\end{tabular}

\subsection{Calibration and Weighing Procedures in Tech Area $V$}

The responsibility for the calibration of balances in Tech Area $V$ is shared by the Physical Standards Division and the Reactor Development and Applications Department. Balances in this area may be placed in one of three general categories as follows. 
(1) Ealances in Open Laboratories in Normal Use -- These halances are potentially contaminated but have a low probability of being contaminated. For these balances, the Physical Standards Division applies the normal standardization and calibration procedures used in certifying uncontaminateo balances.

(2) Balances ir Closed Laboratories Used for Weighing SS Materials (Unirradiated or Irradiated) or Activated and Contaminated Materials -- These balances are usually contaminated.

(3) Balances in Glove Boxes and in Hot Cells -- These balances are always contaminated.

For halances in the latter two categories, the application of normal proceduri:s would require the decontamination of the calibrated weights and could leat tn a loss of these weights as a result of contamination. Constquently, special operating procedures have been developed by the Physical St andards Division and the Reactor Development and Applications Department for lint withing oi accountable nuclear materials, based on the use of clas, s* weights over the applicable balance range.

For each balance that is placed in a glove box or hot cell, applicAli. Clath $s$ wights are obtained and remain associated with that balance throughout its service life. For all other balances (not in glove boxes), a set of class $S$ weights is maintained in Tech Area $V$ for ealibration chiness

*Class $S$ weights are scientific standards precision analytical work. These weights are certified by the Physical Standards Division and supplipd to the Reactor Development and Applications Department. 
The balances in Tech Area $V$ are maintained by the users for their own use (which normally requires greater than accountability weighings), * so that only a spot check of the accuracy and sensitivity of the balances is necessary to verify their integrity prior to their use for accountability weighings. This check is made by (1) placing an appropriate Class S weight on the balance and verifying that the balance reading is within 1 scale division of the certified mass value of the class $S$ weight (e.g., with a 100-g balance, a 100-8 weight should read within $1 \mathrm{mg}$ of the certified weight); and (2) placing additional Class 5 weights on the balance and verifying that the balance reading is incremented by the corresponding weight.

\subsection{Procedures for the Calibration and l'se of Nondestructive Assay Meter}

The Nuclear and Explosives Naterials Control Section employs a SAM-II nondestructive assay meter in making qualitative measurements of the presence of nuclear material. The SAM-II stabilized assay meter ie calibrated with a cesium-1 17 source. However, situations may arise in which normal calibration is unsuccessful and, in these instances, the SAMII meter is returned to the manufacturer (Eberline Corp.) for calibration.

Calibrationa with cesium-137 source are compared and must agree with aignature plottings used as universal standards.

Asays are performed on all strategic quantities of enriched uranium and plutonium at time of receipt and shipment. The material verified may be in various types of containers, birdcages, pits, or assemblies. Irradiated materials are not measured.

orher assays on weapon assemblies, weapon parts, or mockups are performed when requested by a weapon group.

*The accuracy prescribed for accountability weighings \pm 0.5 g below $1 \mathrm{~kg}$ total and $\pm \mathrm{l} g$ above $1 \mathrm{~kg}$. 
The assays are qualitative measurements only to verify the presence or absence of a specific material. No gamma quantitative measurements or certifications are made, and neutrons are not measured.

Each item assayed is moved to a shielded area, or area free of background interference and checked with y Geiger Counter to determine the exact location in the container of the material to be measured. The assay meter is then placed on the surface of the container at the designated location where a full spectrum measuremer: is taken. The measurement is plotted on graph paper and the plotting sheet which also includes serial number, date, location, type of material, and settings used is filed in the Nuclear and Explosives Materials Control Section of fice.

Future planning in the use of the nondestructive assay meter includes: (1) adequate staffing in the Nuclear and Explosives Materials Control Section to allow for measurements of previously measured items at time of internal movement which would be compared with the plot on file, and (2) schedule additional training at Los Alamos Scientific Laboratory in both gamma and neutron quantitative measurements for Nuclear and Explosives Materials Control, or Health Physics Personnel. 


\section{Seal Accountability and Control}

A tamper-indicating seal program is employed by the Nuclear and Explosives Materials Control Section for use on nuclear material containers containing one or more serially numbered items. Sealed containers are considered as assemblies and are inventoried by container unless the seal has been broken since the previous inventory.

\subsection{Procedures for Controlling, Issuing, and Applying Seals}

Button type seals consisting of two metallic parts that, when snapped together form a numbered enclosure around the joined ends of a length of wire. The wire is attached to the container to be sealed in a manner that requires breaking the wire or destruction of the seal to open the container. The seals, with a 5 digit numerically sequenced serial number and "SLA" die stamped on each seal, are controlled and issued by the Nuclear and Explosives Materials Control Assistant.

Seals are used by the Nuclear and Explosives Materials Control Section for material in storage, in Area $v$ for sealing accountable identification cards, for material in the ACRR, GIF Pool, GIF, Surwell, SPR, and material in safes in the MAA. (Sealing of cards instead of material has been accepted by the Nuclear Safeguards Branch, DOE/ALO, for all 1 isted areas except the MAA because the material cannot be visually inspected and if material is moved the identification card is required to accompany the material.) Seals may be issued to other line organizations for other purposes.

Responsible Organization

Nuclear and Explosives Materials Control Section (Nuclear Material Control Assistant)

\section{Action}

1. Order $s$ and maintains stock of serially numbered tamper-indicating seals in a combination-type lock safe.

2. Maintains a log book which contains each seal number, container number appli isd to (or employee to whom issued, if 1 ine org.), date applied, initials of employees applying seal, and the 741 Transaction Document, if being shipped. 
Responsible Organization

Nuclear and Explosives Materials Control Section (Nuclear Material Control Assistant)
Safeguards and Technical Serurity Division (Accountability Clerk)
Nuclear and Explosives Materials Control Section (NN (mtrol Assistant)
Action

3. Seal Installation - Maintains a loose leaf document in container number sequence as a cross reference to the Seal Nuber Log Book which contains MBA number, container number, seal number, date sealed, 741 number, material serial nuaber(s), MR/HR reading, and net weight.

4. Weighs each item before placing it in a container to be sealed.

j. Seals container and inputs the seal number, descriptor for the container, material type, accountable MBA, building, room, number of items, serial number and net weight of each item sealed on the terminal screen titled "Apply Seal - Iniciate."

6. Telephones the accountability clerk in the Safeguards and Technical Security Division and gives her the seal number.

7. Inputs the seal number on the terminal screen titled "Seal Apply - Complete" which adds the assembly data to the computer file and generates a bar code label for the sealed container.

8. Forwards the bar code label for the sealed container to the Nuclear and Explosives Material Control Section as sistant.

9. At taches the bar code label to the sealed container for identification and inventory.

10. If appropriate, prepares form SA 2042-D, "Nuclear and Radioactive Material Transfer", in accordance with procedures in Section 5 of this chapter.

11. Seal Removal - Breaks seals and removes material from containers as requested by using organizations and/or for shipment. 
12. Cancels seal numbers as seals are brcicen by drawing through the seal number 1 ine in the $\log$ book.

13. Explains a braken seal by recording the reason for breaking in the concainer cross reference document.

14. Inputs the sea number and container serial number of the broken seal container on the terminal screen titled "Break Seal - Initiate".

15. Telephones the accountability clerk and gives her the broken seal number.

Safeguards and Technicai Security Division (Accountability Clerk)

16. Inputs the seal number on the terminal screen titled "Seal Break Complete" which disassembles the items in the computer file. 
11. Exporting Accountable Nuclear Materiale

\subsection{Procedures for Exporting}

NRC Authorization - If shipment is in conjunction with an NRC agree-ment, the sending arganization will:

1. Complete form "Request for Foreign Contract Number" (available: in the Safeguards and Technical Security Division) and mail to the Union Carbide Corp., Oak Ridge, Tenn.

2. Upon receipt of the contract number from Oak Ridge, complese Form NRC-7, "Application for License to Export Nuclear Material and Equipment" (Available in the Safeguards and Technical Security Division) and mail to the Assistant Director for Export/Import and International Safeguards, U.S. Nuclear Regulatory Commission, Washington, D.C. 20555.

3. Telephone the Department of Commerce to explain the shipment and obtain their authorization code shich must be inserted in the "Authentication" block on Form 7525-V, "Shipper's Fxport Declaration" (prepared and approved by the Traffic Management Division, 3743).

DOE Authorization - The following procedures can be used for all exports, including NRC agreement ahipments. The sending organization will:

1. Complete Fr. "'......est for Foreign Contract Number" (available in the Safe: .... . Technical Security Division) and mail to the Union s rin. Corp., Oak Ridge, Tenn.

2. Upon receipt of the contract number from Oak Ridge, prepare a memorandum addressed to D. L. Krenz, Special Programs Division Lirector, DOE/ALO, requesting authorization 10 ship the material, and include the following information. 

a. Description of material
b. How the material will be used
c. Will a Sandia scientist be at destination?
d. Length of time it will be used and benefits to be derived
e. Will the material be returned?
f. Is there a Sandia contract? If so, attach a copy
$g$. Any correlation to another contract, or inter- national agreement?

3. Furnish the contract number and packaging information to the Traffic Management Division who prepares the Shipper's Export Declaration in 5 copies.

4. Forward the memorandum to the Traffic Management Division to be forwarded with the approved Shipper's Export Declaration to $D$.

L. Krenz, DOE/ALO

\section{Responsible Organization}

Sending Organization
Nuclear and Explosives Materials Control Section (NM Coordinator)
Action

1. Prepares Form SF 6951-A, "Property Action," Form SA 6550-EA, "Information for Hazardous Material Shipments," Form SA 2042-D;, "SS and Radioactive Material Transfer" trans lerring material to MBA 01, BlJg. 819 (see Exhibits 6, 11 and 12, Chapter $X$ ).

2. Transfers material and shipping paperwork to MBA Ol in accordance with Section 5 of this chapter.

3. Prepares memorandum addressed to D. L. Krenz, Special Programs Division Director, DOE/ALO, requesting authorization co ship material (Eor DOE authorization on $1 y$ ).

4. Forwards the memorandum and contract number to the Traffic Management Division.

5. Prepares Nuclear/Radioactive Material Packing Slip, Form SF 6476-I, and adds to the shipping paperwork packet. 
Responsible Organization

Nuclear and Explosives Materials Control Section (NM Coordinator)

Shipping and Receiving Division

Traffic Management Division

Shipping and Receiving

Division (Packaging

Eng ineer)

Traffic Management

Division (Traffic Clerk)

Nuclear and Explosives Materials Control Section (NM Coordinator)
Action

6. Prepares Nuclear and Radioactive Material Transfer, Form SA 2042-D, transferring accountability for the material to the Packaging Section, MBA 66 , in accordance with section 5 of this chapter.

7. Packages material, completes paperwork, and forwards Form SF 6476-I, Nuclear/Radioactive Material Packing Slip, and Form SF 6951-A, Property Aition, Govt. Bill of Lading and Hazardous Material Form to the Traffic Management Division.

8. Determines carrier and routing of shipment, record data required for the Shipper's Export Declaration, and returns shipping paperwork to the Shipping and Receiving Division.

9. Completes 5 copies of the Shipper's Export Declaration, signed by the Traffic Management Division supervisor, and forwards to D. L. Krenz, DOE/ALO, with the memorandum from the sending organization, if DOE authorization is required.

10. Ships material if accompanied by NRC license and completed Shipper's Export Declaration.

11. Transfers packaged material to MBA 01 in accordance with Spetion 5 pending DOE authorization to ship.

12. Forwards a copy of the Shipper's Export Declaration authorizing shipment when returned from DOE.

13. Upon receipt of the Shipper's Export Declaration, transfers packaged material and shipping paperwork to MBA 66 for shipment, in accordance with Section 5 of this chapte:. 


\section{Special Procedures}

Because of the diversity of operations involving nuclear materials, unique situations arise which require special operational procedures to be devised. The Safeguards and Technical Security Division and the Nuclear and Explosives Materials Contrnl Section assist using organizations in the formulation and implementation of such special procedures. This section contains special procedures currently in use.

\subsection{Procedures for the Verification of the Presence of SNM in Tech Area V}

The principal use of SMM in large quantities in Tech Area $V$ involves the SPR reacturs. These reactors are used in the Kiva (Building 6590) and stored in a vault outside the Kiva in the breezeway; fissilc reactor components may also be stored in the vault.

Occasionally, additional SNM is present in significant quantities in Tech Area $V$ as part of an experiment (e.8., weapon components or reactor safety experiments). When such experiments are located in Tech Area $V$, they may be stored in the Kiva, the vault, or the instrument building. These areas are equipped with remote air monitors (RAM's) to monitor the radiation level at all times. These RAM's (one in the Kiva, three in the breezeway, and one in the instrument builting) are set to trigger an alarm when radiation levels exceed $100 \mathrm{mR} / \mathrm{h}$ and may be monitored from remote readouts located at che console and in the health physicists' office. When not in storage, experiments may be secured in the ACRR reactor or in otlor prescriabed areas of Tech Area $V$, although these other areas require 24-hour surveillance by two guards as an added security precaution.

Responsible Organization

Reactor Development and Applications Department or

Health Physics Division
Action

1. When the Kiva is open, the reactor is shutdown, and personnel are present, checks the radiation field of the reactor with a portable gammasensitive radiation detector. 
Responsible Organization

Reactor Development and Applications Department or

Health Physics Division
Reactor Development and Applications Department or

Health Physics Division
Action

1.1 A reading significantly above the background radiation level indicates that the materials are presents.

2. When the Kiva is secured and che reactor is shutdown, checks the reactor visually from the SPR control room using the television monitoring system.

3. When the Kiva is secured and the reactor is operating, is not required to make any checks.

4. When the storage vault has been opened for any purpose, checks all of the SNM in the vault with a portable gammasensitive detector in order to verify the presence of SNM.

4.1 A reading significantly above the background radiation level ind icates that the materials are present.

5. When SNM is located in experiments, checks (where possible) with a portable pamma-sensitive detector.

5.1 A reading significantly above the background radiation level ind $i-$ cates that the materials are present.

5.2 Whenever the gamma detection method cannot be used because of high-radiation environments or inaccessibility (such as when the experiment is located in the ACRR irradiation cavity), the experiment containment is visually checked to ensure that the materials have not been disturbed.

5.2.1 If discrepancies are noted, the materials are removed to a location with low background radiation and checked with a portable gamma-sensitive detector. 
12.2 Procedures for the Performance of Emergency Inventories of SNM in Tech Area V

Upon request, MBA's are required to perform an emergency inventory of SNM in their possession. The Safeguards and Technical Security Division receives the initial notification of the requirenent for such an inventory and instigates the performance of the emergency inventory.

Responsible Organization

Safeguards and Technical Security Division

Reactor Development and Applications Department (Manager)

Using Organization (Custodian)
Reactor Development and Appl ications Department (Manager)
Action

1. Notifies the Manager of the Reactor Development and Applications Department of the requirement for an emergency inventory of SMM in Tech Area $V$.

2. Notifies all custodians in Tech Area $V$ that an emergency inventory of SNM's is required.

3. Performs the emergency inventory of all SNM's in its possession.

3.1 All locations where SNM is located are physically examined, and the materials are monitored in accordance with the procedures set forth in Section 12.1.

4. Reports the results of the emergency inventory to the Reactor Development and Applications Department.

5. Combines the results of all of the emergency inventories performed in Tech Area V.

6. Reports the combined results to the Safeguards and Technical Security Division. 
CHAPTER VI

ACCOUNT ABILITY

1. Responsibilities

The accountability of nuclear materials requirce rigid coordination and cxact recordkeeping of all transactions and activities invalving nuclear materials. The Safeguards and Technical Security Division is assigned primary responsibility for the accountability of nuclear materials in the possession of Sandia National Laboratories, Albuquerque. In fulfilling this responsibility, the Safeguards and Technical Security Division maintains records and issues reports reflecting nuclear material transactions and inventories. Corporate records of nuclear materials for which Sandia is accountable to the DOE are maintained in a comprehensive computer file which is supplemented by shipping and receiving logs that are maintained manually. Furthermore, all documents related to nuclear material transactions and expenditures are filed and held as necessary to satisfy the audit and retention requirements of the DOE and Sandia National Laboratories. DOE Order 5630 describes the reporting requirements specified by the DOE and provides a profile of the responsibilities incumbent upon contractors possessing accountable nuclear materials. Specific responsibilities which the Safeguards and Technical Security nivision undertakes in order to fulfill the accountability function are to:

- From Form DOE-74l transfer accountability documents received by mail, input data into the computer before processing the physical receipt of materials. 
- Maintain the corporate shipping and receiving logs in which transfer accountability data and adjustments to inventory are recorded.

- Maintain files of transaction documerts, lists, and reports including:

- Form DOE-741 transfer accountability documents.

- DOE authorizations for shipments to the military.

- Current classified mail channels.

- Contractor and licensee Reporting Identification Symbols.

- Assembly/Disassembly forms.

- Burial reports.

- MSR and status of inventory reports.

- Financial reports.

- Report end-of-the-month inventory balances (by material (ype, project number, and VLA) to the DOE.

- Balance the nuclear material inventory monthly in conjurction with the Property Accounting Division.

- Direct the receipt, processing, and distribution of incoming Form DOE-741 transfer accountability documents. 
- Prepare Form DOE-741 transfer accountability documents for all shipments of nuclear materials to or from the military.

- Compare incoming Form DOE-74l transfe- accountability documents with the receiving paperwork and resolve any discrepancies which are noted.

- Prepare and distribute Form DOE-74l transfer accouncability documents, via Sacnet or mail, for all shipments and disposals of nuclear materials.

- TWX pertinent shipping information to receivers of shipments made during the last 5 calendar days of a month.

- Preparp receipts for classified information to accompany Form 74l, Nuclear Material Transaction Report, on shipments of nuclear materials which are cıasified Secret, and are sent by mail.

- Calculate the material decay for ${ }^{238}$ Pu materials at the time they are shipped, and monthly for other designated materials that remain in the inventory.

- Record calculated material decays in the computer file.

- Prepare input for daily update of Sandia's computer records and the periodic update of DOE/ALO and NMMSS computer records.

- Distribute inventory computer listings to MBA custodians following each physical inventory and reconciliation, and upon request. 
- Distribute, monthly or upon request, the alarm report to the Nuclear Materials Manager in the Safeguards and Technical Security Division, the sealed container report to the Nuclear ar.d Explosives Macerials Control Section, and the financial report to the Property Acrunting Division. 


\section{Job Description}

The accountability functions of the Safeguards and Technical Security Division are performed by accountability clerks. Job descriptions for 1!tse positions are puslished by the Position Evaluation and Job Classification Division and retained by the Safeguards and Technical Security Dit.sion and the Position Evaluation and Job Classification Division in their files. Figure vl-l provides thr jublishad description for the Nuclear Material Accountability Control Clerks who carry out the accountability activities. 


\section{J08 OESCRIP TION}

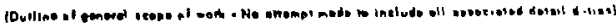

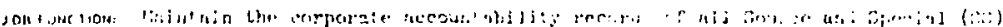

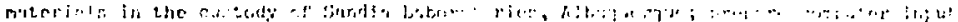

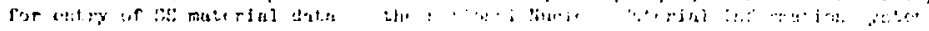

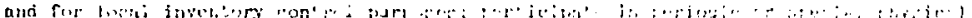

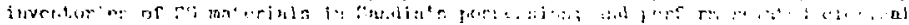

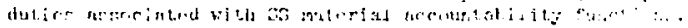

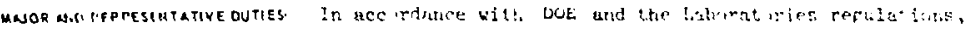

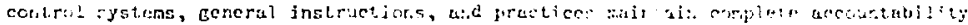

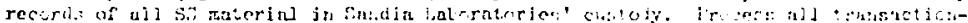

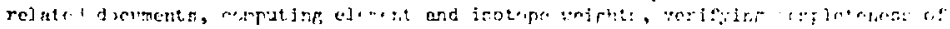

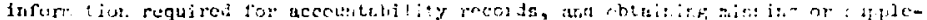

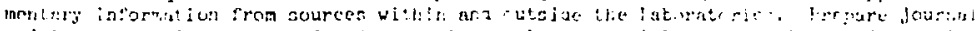

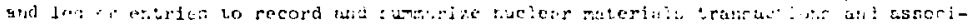

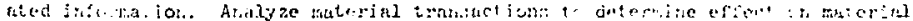

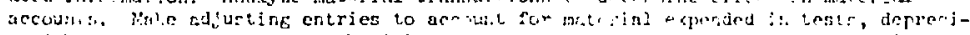

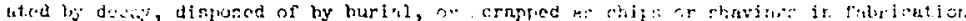

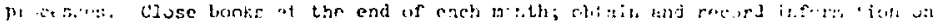

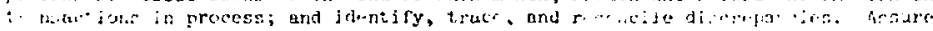

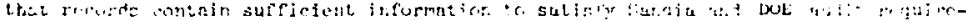

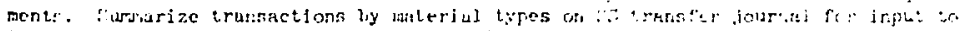

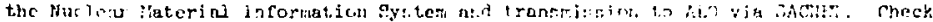

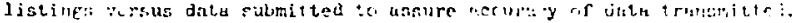

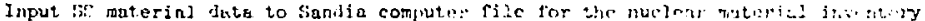

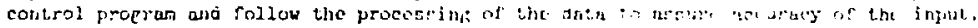

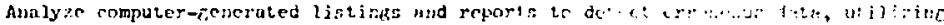

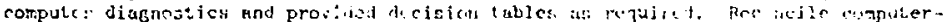

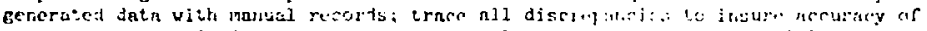

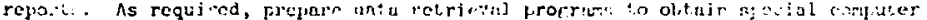
listil, ; or reporti.

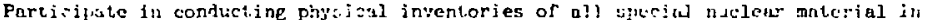

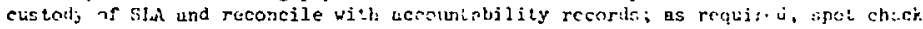

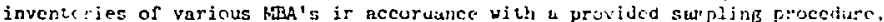

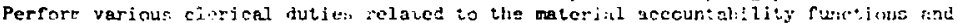
the lluclear Materius lenagenent Sechics's oferations includine activities such as

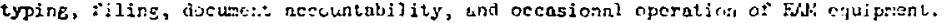

Figure VI-1. Job Description for the SS Material Accountability Clerks 


\section{Accountability Records}

To ensure the rigorous accountability of nuclear materials in accordance with DCE regulations, Sandia National Laboratories maintains an extensive computerized data base containing all information pertinent to niclear material operations. This data base is updated daily to ensure that all data changes are recorded promptly and accurately. These data are sorted in various ways and recovered to generate the reporis and listings discussed in Section 11 of this chapter. To supplement this data bose, accountability clerks in tho Safeguards and Technical Security Division maintain stipping and receiving logs which document all nuclear material transfers to or from Sandia National Laboratories. The Safeguards and Technical Security Division also keeps files of numerous transaction documents as required to satisfy the audit and retention requirements stipulated by the DOE and Sandia National Laboratories. Fipure VI-2 illustrates a simplified flowchart for the nuclear material accountability records processed by the Safeguards and Technical Security Division.

At the heart of the DOE accountability system are Form DOE-741, "Nuclcar Material Transaction Report" (Exhibit 15, Chapter VIII), and Form AL-131, "ADP Transcription Sheet, Nuclear Material Tranfers" (Exhibit 16, Chapter VIII). Form DOE-741 accompanies all nuclear material transfers between Reporting Identification Symbols (RISs) and contains all pertinent information regarding the materials. Form AL-131 is the machine-readable form of 741 information used for transmitting data directly from the Sandia computer to DOE/ALO and NMMSS computer systems. 


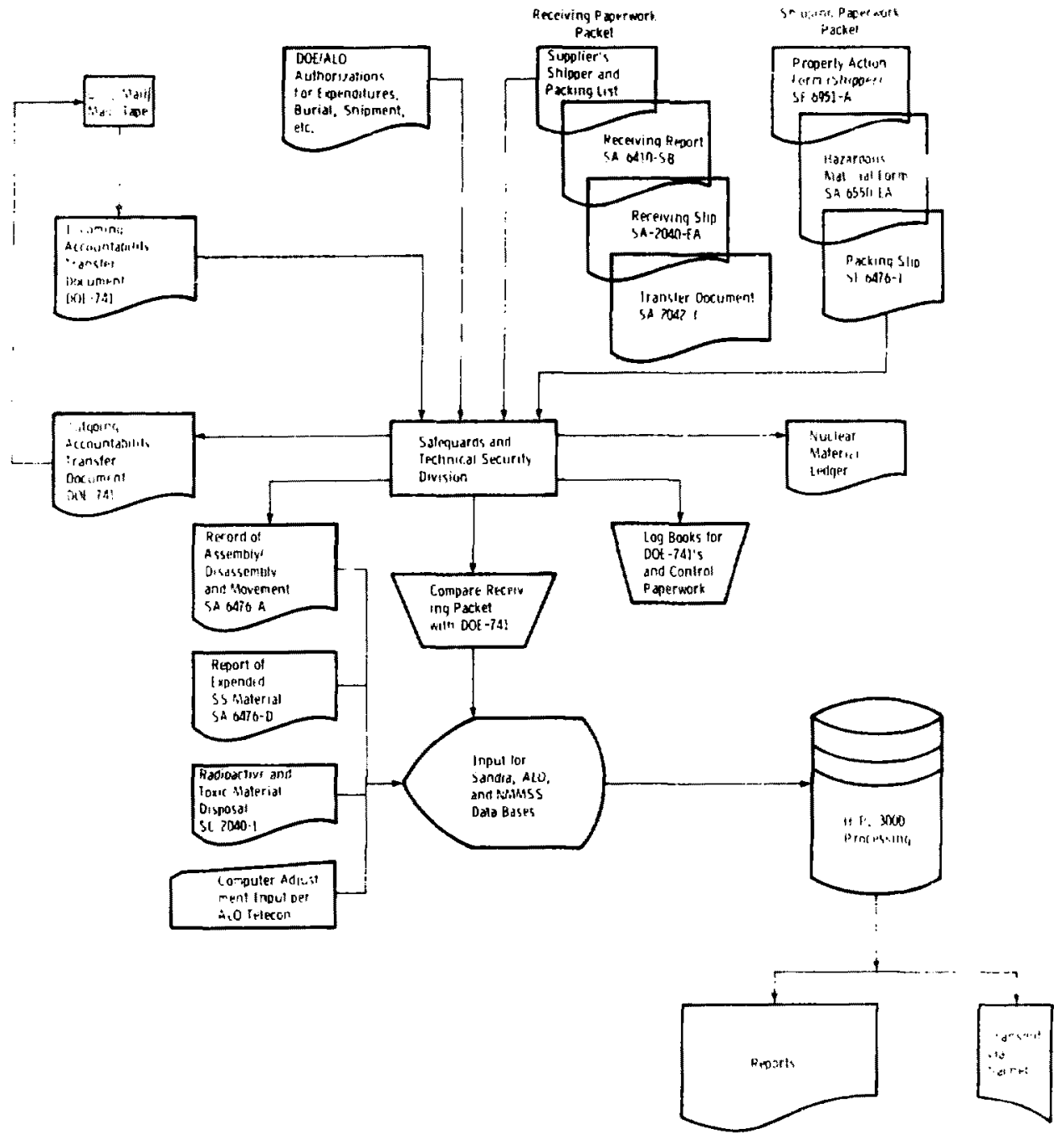

Figure Vi-2. Simplified Flowchart for Nuclear Material

Accountability Reiords 


\subsection{Procedures to Maint aining the computer corpurate Ledger}

\section{hesponsible Urganization}

Safeguards ait Technical Securits iJivision (Accomentatility (ilerk)
Action

1. Maintains a $\log$ book in which $14 \mathrm{ls}$ and $\mathrm{IA}$. Arr tacorded to ensure at ntup changes are mati L. II lata base.

2. woldes the inaterial transtur inform: ina an Form DOE-74!.

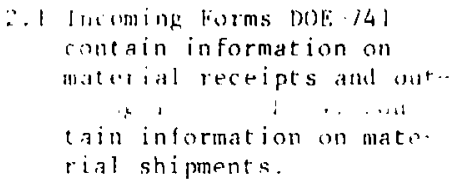

3. Receives adjustment and/or expenditure iniormation an form $S A$ $6476-i v$, "Inventory Adjustment Forn" (F.xhibit 19, Chapter VIJII.

3.1 The Nucleat Matetials Mana Ler prepares form SA 6476-NH tor adjustments resulting from machining, normal oper. ational losses, and routine test expenditures.

3.2 Cicnerates Form SA 6476-NF tor decay and weightrounding activity.

4. Queries open $741 \mathrm{~s}$ in data base on the ALO menu via terminal.

5. Inputs 74ls on terminal screen ALO 051 or ALO 052, depending upon whether the source input is from tape or hard copy.

6. Nueries terminal screen JT:S 054 to check weights before imputting adjustment data from IAF.

7. Inputs adjustment data on the appropriate IAF terminal screen (i.e., decay, loss, one too many, many to one, etc.). 


\subsection{Procedures for the Update of Sandia's Computer Records}

To ensure the correctness of Sandia's computerized nuclear material data base, daily updates are performed so that all data changes are recorded promptly and accurately.

Responsible Organization

Safeguards and Technical Security Division (Accountability Clerk)
Action

1. Queries open receipts, shippers, and 741 data to AlO that remains incomplete to start the day's activity.

2. Inputs daily transactions and updates information in accordance with Section 3.1 above.

3. Concludes each day's activity by generating a daily closing report from terminal screen CLS 051 .

3.1 Checks the daily closing report against the input source documents and the $\log$ book.

\subsection{At month's end, performs monthly closing from ter-} minal screen CLS 052 .

\subsection{Procedures for the Update of the NMMSS Computer Records}

DOE regulations require that prompt notification be supplied to the Nuclear Materials Management and Safeguards System (NMMSS) of all corecions to the nuclear material inventory, including project number changes, receipts, shipments, and all other adjustments to inventory (such as expenditures, disposals, decay, etc.). Input internal project transfers (project number changes) on the terminal screen format of Form DOE-749, "ADP Transcription Sheet, Internal Project Transfers" (Exhibit 22, Chapter VIII). The Form AL-131, "ADP Transcription Sheet, Nuclear Material Transfers" (Exhibit 16, Chapter VIII) is used for transmitting all other data to the DOE/ALO and MMSS. 
Responsible Organization

Safeguards and Technical Security Division (Accountability Clerk)
Computer Communications Section

DOF. / ALO
Action

1. Determines the daily activity data that must be transmitted to ALO.

2. On the terminal, selects from the ALO menu the appropriate reporting format for transmitting the required data.

3. Generates daily, following close of business, output tapes for transmission to ALO.

4. Classifies output tapes SRD and has a reference symbol number assigned and logged by the Safeguards and Technical Security secretary.

5. Handcarries, at the end of each workday, the tapes with Form SC 2900-JC, "Record of Loaned Document and Routing slip", to the computer communications section, and picks up incoming tapes for processing.

6. Signs Form SC 2900-JC for receipt and returns it to the carrier for filing in the Safeguards and Technical Security Division office until the tapes are returned.

7. Transmits tapes via Sacnet to ALO and required distribution.

8. Extracts data required for the ALO data base and transmits to Oak Ridge the data required for NMMSS. 


\section{Receipls}

Thu arountability of nuclear materials received is supporte: wy a

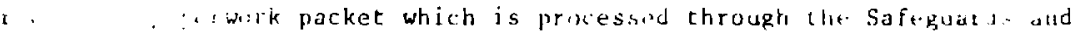

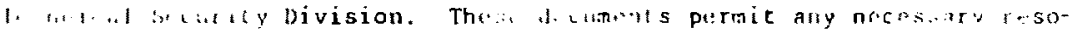

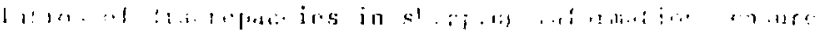

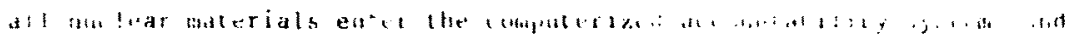

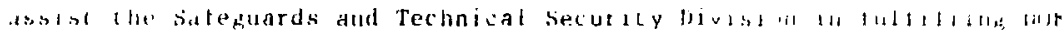

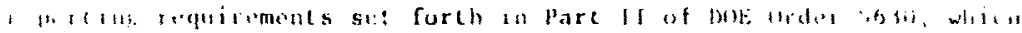
$\$ 111,4$

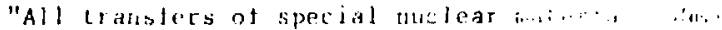

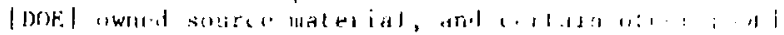

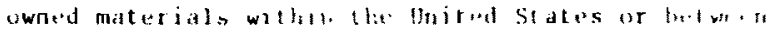
the United States ant fulfign ontilies shali b. reflected on a Nuclear Material Transaction Repint. Form $\mid$ DOE $\mid-741 \ldots$

"Ill any instance where a faciljty subject to this wat

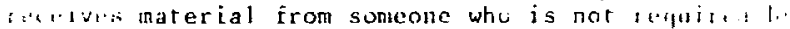

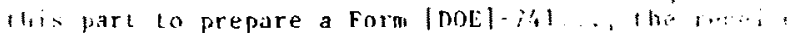
iumb prepare and distribute thre form promptly
}

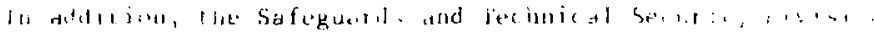

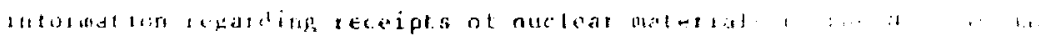

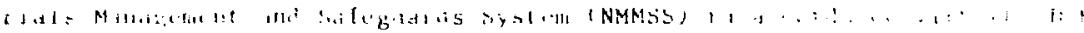
justial tons.

This section includes the accountability procefur's for receipts of nuslear naterials. The corresponding control promedures are includel ju Section 4, Chapter $v$.

\subsection{Procedures for the Accountability of Nuclear Material keceipls}

\section{Responsible Organization}

N.i i i.l and Explosives

Mat-IJils Control Section

(NM ciogt dinator)

\section{Action}

1. On the terminal, inputs the initial receiving data on the RCVOSI screen titled "Brild:llisplay keceipt (Concrol)" following the weighing of material. 
1.1 For nonweighable material, holds receiving paperwork and checks with the accountability clrrk in the Safeguards and Technical Security Division for 741 data before entering on the RCVOSl screen.

1.2 Assigns $\log$ number to incoming material.

2. Following input of data on the terminal, handcarries the completed receiving paperwork packet to the accountability clerk.

2.1 The receiving packet consists of the shipper's packing 1 ist, two copies of the receiving report on either Form SA 6410SB, "Material Receiving Report" (Exhibit 5, Chapter VIII), or on Form SA 6410-SC, "Material Variref Receiving Report" (Exhibit 6, Chapter VIII), and the nurlear materials receiving sip on Form SC 2040-EA, "Radioactive and Nuclear Materials Receiving Slip" (Exhibit 7, Chapter VIII).

Safeguards and Technical Security nivision (Accountabjlity Clerk)
3. Files the receiving packet in a ponding file until the Form DOE-74l, "Nuclear Material Trans" action Report" (Exhibit 15, Chapter VIII) is received.

3.1 One copy of the receiving report is filed and mointained fo: audit purposes.

3.2 For materials received from the military, the accountability clerk inputs Form DOE-74l data from the sender's paperwork in accordance with earlier Section 3.1 and transmits it to DOE/ALO in accordance with Section 3.3 above. 
Safeguards and Technical

Security Division

(Accountability Clerk)
3.3 If for some reason the content of the materials cannot be determined independently within 10 days of receipt, tise accountability clerk prepares Form DOE-284, "SS Material Transfer Receipt" (Exhibit 24, Chapter VIII) as an interim document and distributes the original to the shipper with copies to DOE/ALO and to the shipper's field office (if different).

4. Upon ils arrival, records the receipt of the Form DOE-741 in the log book.

\subsection{If the form is classified} Secret, the accountability clerk must sign a receipt for the document at the time of delivery. (Copies received by mail only.)

5. Files the Form DOE-74l in a pending file until the receiving packet arrives.

5.1 Queries open receipts on terminal screen.

5.2 If DOE-74I is received by mail, inputs data to the computer on terminal screen ALO 052 titled "Build ALO Input From Terminal for NMS."

6. When both the receiving packet and the Form DOE-741 have arrived and been matched, transfers all of the documents to a work folder.

6.1 Both a Form DOE-741 and a nuclear materials receiving slip are required in order to process the transaction.

6.2 Gross weight, packaging, and $t$ ransportation information are required on receipts from the DOD. 
7. Matches the data entries on the Form DOE-741 with those on the receiving paperwork.

\subsection{Discrepancies noted between the Form DOE-741 and the receiving paperwork are reconciled with the Nuclear and Explosives Materials Control Section or (if necessary) with the shipper's accountability personnel.}

8. Completes the receiver's portion of the Form DOE-741 by assigning the appropriate project number and recording the material type, composition code, owner code, use code, number of items, serial numbers, element weight, weight percent isotope, and isotope weight for each line item, which are input to the computer on terminal screens RCVO52, RCVOS4, and RCV057.

9. The data from the Form DOE-741 are input on the terminal format of Form AL-131, "ADP Transcription Sheet, Nuclear Material Transfers" (Exhibit 16, Chapter VIII), for processing to DOE/ALO and required distribution in accordance with earlier Section 3.3.

10. On copies received by mail, obtains the signature of the NM Representative on the Form DOE-741 and distributes the copies as required (including one copy to DOE/ALO and one copy to the shipper). Otherwise, copies are transmitted via Sacnet.

10.1 If the form is to be mailed and is classified Secret, the accountability clerk prepares a "Receipt for classified Information" on 
Safeguards and Technical

Security Division

(Accountability Clerk)
Form SA 2900-J (Exhib-r 25, Chapter VIII) and aisc obtains the signature of LA. mailman picking up the furm

10.2 for shipments from the military, the distribution it lie $101 \mathrm{~m}$ DOE-14l it. cralualol on a casob; 1 ...st basis, since tho varicus branches of the servica require distributions different (normally inse? extcusjue) than thuse f.n nonmilitary shipment,.

11. Records the distribution of the completed Form DOE-741 in the log book.

12. Inputs form 741 data into the computer in accordance with earlier Section 3.1 .

12.J Checks the transmit $\left\{\mathrm{w}^{\prime}\right\}$ ial is against the source document on the daily closing report.

12.2 Files the completed form DOE-741 and the receiving packet in the "Current Month's Business" working file.

13. Once a month, Eurnishes a monthly cost report and balance sheet code report to the Property ACcounting Division of all transactions causing adjustments to the ledger during the month.

13.1 The cast report includes: shipping RIS, receiving RIS, $74 !$ no., MT, ER, cost, element wt. , \% i sotope, isotope wt., project no., comp. code, MSR no., document no., action date, serial no., and reporting date. 
13.2 The cost report summarizes costs by material type on a monihly recap report which includes: material type, previous months inventory dollar value, changes in dollars, and current months inventory dollar value.

13.3 The balance sheet code report summarizes costs by project number, enrichment range, and material type within balance sheet codes. Also included on the report are composition code and element weight.

14. Files the form DOE-74l numerically in the 741 receiving file.

15. Files the receiviug packet chronologicaliy in the recejving file.

16. Updates the Sandia and NMMSS computer records in accordance with the procedures set forth in carlier sections 3.2 and 3.3 . 


\subsection{Procedures for the Accountability of Nuclear Material Constructive Receipts}

The following procedures have been established for the accountability of nuclear material not physically received by month end closing, but for which a DOE 741 transaction report has been received.

\section{Responsible Organization}

Safeguards and Technical Security Division (Accountability Clerk)

\section{Action}

1. Inputs 741 data in accordance with earlier Section 3.1.

2. Inputs DOE project no., comp. code, country control no., and wt., \% isotope on terminal screen RCv055 titled "Build Constructive Receipt."

2.1 On terminal ALO menu, selects DOE $A L-13$ ! format and transmits data to DOE/ALO.

2.2 Input to computer generates ALO transmission only and data are not entered in Sandia data base. 


\section{Shipments}

In addition to rigorous DOE and Department of Transportation safeguards requirements, shipments of nuclear materials are governed by accountability and reporting requirements established by the DOE. The Safeguards and Technical Security Divigion and the Traffic Management Division assume primary responsibility for fulfilling DOE reporting requirements set forth in Part II of DOE Order 5630, which states:

\footnotetext{
"The shipper [Safeguards and Technical Security Divisior l shall either include the copies of the transfer report intended for the receiver with each shipment of nuclear material, or, by other means dispatch the receiver's and other copies of the Form [DOE]-74] on the same day the material is shipped.

"Each shipper [Traffic Management Division] is isponsible for providing the intended receiver with all pertinent information concerning a proposed shipment of nuclear material. For shipments of special nuclear material totaling more than 350 grams of contained U-235, U-233, plutonium, or any combination thereof, or more than one gram of tritium, the shipper shall, on the agreed day of shipment, provide such information to the receiver by telephone [if not classified] with confirmation by teletype or telegram."
}

In addition, the Safeguards and Technical Security Division transmits information regarding shipments of nuclear materials to the Nuclear Materials Management, Security, and Safeguards System (MMMS) in accordance with the DOE instructions issued in 1972 and subsequent memorandum changes.

This section includes the accountability procedures for shipments of nuclear materials. The corresponding control procedures are included in Section 7, Chadter V. 


\subsection{Procedures for the Accouncability of Nuclear Marerial sinimints}

Responsible Organization

Nuclear and Explosives Materials Control Section (NM Coordinator)

Nuclear and Explosives Materials Control Section (NA Coordinator)
Action

1. Inputs initial shipping data on terminal screen SHPOSl titled

"Build/Display Shipment."

?.1 Assigns log number to outgoi shi pment.

1.2 If shipment is to DOD. inputs HD number in comments field.

1.3 Records computer-g nerated "RIS" number on shlpping paperwork.

2. Forwards the completed shipping paperwork packet to the accountability clerk in the Safeguards and Technical Security Division.

2.1 The shipping packet consists of the shipper on Form SF 6951-A, "Property Action" (Exhibit 11, Chapter $X$ ), the hazard sheet on Form SA 6550EA, "Information for Hazardous Material Shipment" (Exhibit 12, Chapter $X$ ), the packing slip on Form 6476-I, Nuclear/ Radioactive Material Packing Slip" (Exhibit 8, Chapter VIII), Form DOE-740, "ADP Transcription Sheet, Nuclear Material Transaction Journal" (Exhibit 9, Chapter VIII), and the transfer document on Form SA 2042-D, "Nuclear and Radioactive Material Transfer" (Exhibit 6, Chapter X), with wich the materials were turned in for shipment.

3. Records the date, 741 no., and quantity in the shipping log book. 
Shipping and Recaiving Section fPackaging Clirk or Nuclear Materials Control Section (for SNM) (NM Coordinator)

Hea! th Physics Division (Hoalth Physicist)

Shipping and Receiving Division (Packaging Engineer) or Nuclear Materials Control section (for SNM) (NM Coordinator)

Traffic Management Division (Traffic Clerk)
4. If the materials bcing shipped require a courier, handcarries the shipping packet to the Security Standards and Operations Department for recording of the RIS number and material weights ir the security $\log$.

i. Handcarries the shipping packet to the Packaging Section of the Shipping and Heceiving Division.

6. Packages the materials i: accordance with DOE and DOT regula$t$ ions, based on information contained on the sheet.

6.1 SNM is packaged by the Nuclpar ano Explosive Materials Control Section in specification-type containers to comply with criticalizy requiremencs (as specified in SLI 2047), and cecurity seals are applied.

7. Records the container type and gross weight on the Form DuF-? 40 .

8. Contacts the Hialth Physics Division for inspection of the packaged materials.

?. Nonitors the radiation level (in $m R / h)$ at the surfact of the packaged materials.

10. Verifies that the correct radioactive labeling has been attached.

11. Enters the transport index and other required data on the packing slip, signs, and retains one copy.

12. Forwards the shipping packet to the Traffic Management Division.

13. Determines the method of shipment and compleces the transportatinn portion of the Firm DOE-740. 
Shipping and Receiving Divigion (Shipping Clerk)

Safeguards and Techinical

Security Division

(Accountabilitv Clerk)
14. Retains one copy of the packing slip.

15. Arranges appropriate carrier service for the onipment.

16. Forwards the shipping packet to the Shipping and Receiving Division.

17. Ships the materials, enclosing the green copy of the shipper and the packing slip.

\subsection{The white copy of the shipper is used as a gate pass.}

18. Notifies the Safeguards and Technical Sccurity Division when shipment has been made.

19. Picks up the completed copies of the shipper, the packing slip, Form $D O E-740$, and material identification labels of material shipped.

20. Retains one copy of the shipper and one copy of the packing slip for the Safeguards and Technical Security files.

21. Queries the computer on terminal screen SHPOOl titled "Query Open Shiprants" to obtain the required shipping log number.

22. Inputs on terminal screen SHPOSS titled "Build/Display Shipment" the shipping $\log n \%$. and action code.

23. Verifies serial numbers on material identification labels recurned from the shipping org. against those entered into the computer for that shipping log number on terminal screen SHP053.

23.1 Item number differences require that the data be reentered from Step l of this section. 
24. Completes shipping transaction by inputting on terminal screen SHP054 titled "Complete Shipping" the shipping log number, process action code, miscellaneous information descriptiun, and action date (date shipped).

24.1 If shipped to DOD or 1 icensees, includes shipped for/ to accounts, transportation, and packaging information.

24.2 If exported to a non-U.S. location, includes the export license number on the 741 (see DOE Order 5630).

25. Adds negligible quantity items on terminai screen SHPOS6 titled "Add Negligible Quantity Items to NMS" which programmatically includes them on the DOE Form 741 with the accountable quantities.

Safeguards and Technical Security Division (Accuuntability Clerk)

26. Generates Form DOF $741 \mathrm{~s}$ on tape for Sacnet $t$ ansmission and hard copy for file and for distribution to non-Sacnet rucipients.

26. 1 Jbtains signature of NM representative on copies to be mailed.

26.2 Distributes copies of the signed Form DOE-74! as required.

26.3 If manually prepared and distributed, three copies of the Form DOE-741 are sent to the contractor or company to which the materials are being shipped, one copy is sent to DOE/ALO, and one copy is retained in a suspense file until a signed copy is returned from the recipient. 
Accion

26.4 For shipments to the military, the distribution of the Form DOE-741 is evaluated on a caseby-case basis, since the various branches of the service require distributions different (normally more extensive) than those for nonmilitary shipments, and notifica$t$ ion is supplied to DOE/ALO promptly (within 24-48 hours) so that weight data can be provided in a timely manner.

26.5 If the form being mailed is classified Secret, the accountability clerk prepares a "Receipt for Classified Information" on Form SA 2900-J (Exhibit 25, Chapter VIII) and also obtains the signature of the mailman picking up the form.

Safeguards and Technical Security Division (Accountability Clerk)
27. Files the completed Form DOE-74] and the shipping packet in the "Current Month's Business" working file.

28. Once a month, furnishes a monthly cost report and balance sheet code report to the Property Accounting Division of all transactions causing adjustments to the ledger during the month as described for receipts in previous Section 4, step 14.

29. Files the Form DOE-741 numerically in the 741 shipping file.

30. Files the shipping packet chronologically in the shipping file.

31. Updates the Sandia and MMMSS computer records in accordance with the procedures set forth in Accountability Records Sections 3.2 and 3.3 in this chapter. 
B...use. of the djnamic nature of operations involving nuclear materials, frequent adjustments are made to the inventory of nuclear macerials in the pussession of Sandia National Laboratories. Procedures for adjustments to inventory resulting from the receipt or shipment of nuclear materi: is are included in Sections 4 and 5 , respectively, and procedures for uhire adjustments to inventory are included in this soction. Such adjustments may result from expenditures of materials in tests or experiments, from the disposal of scrap, from the radioactive decay of nuclear materials, from the assembly/disassembly or modification of materials, or from accidental losses of nuclear materials.

DOE regulations require that approval be obtained in advance for any changes in size, shape, form, or weight of nuclear materials. This requirernent applues to such activitips as machining of nuclear materials, chemical action on nuclear materials, and destructive tests (eicher with or without explosives) as described in Chapter IV, Section 7.1.

\subsection{Prosedures for the Accountability of Nuclear Material Expenditures}

Responsible Organization

Safeguards and Technical

Security Division

(NM Vanager)

Ising nrganization
Action

1. Upon receipt of the authorization, for removal of expenditures from the records, from DOE/ALO, files the authorization for future use in removing the expended materials from the records.

2. Performs the scheduled activities.

3. Recovers and measures the scrap ind/ar excess material residues remaining after the scheduled activities.

3.1 No nuclear material may be disposed of without prior authorization from the NM Manager. 
Using Organization

Safeguards and Technical Security Division (NM Rep., NM Manager, Accountability Clerk)
Action

4. Turns the scrap and/or excess material residues in to the Nuclear and Explosives Materials Control Section for disposition in accordance with the procedures set forth in Sections 7 and 8, Chapter v.

5. Prepares and submits Form 6476-ME, "Modification/Expenditure of Nuclear Materials" (Exhibit 17, Chapter $X$ ) to the Safeguards and Technical Security Division reporting the actual quantitie of accidental losses of materia.s, materials expended, the amount of materials converted to scrap, excess material residues, and/or a new ac countable item and the method by which these quantities were determined.

6. Prepares Inventory Adjustment Form (IAF) from the Using Organization's Form 6476-ME which includes the date, MBA, material type, enrichment range, case number, activity that generated the adjustment, balancing debit and credit weight entries by serial number explaining the adjustment, MSR codes per line item entry, disposition code, NM manager's approval signature if routine test, clerks initials and date of action performed.

7. Writes the IAF number and date removed from the accountability records on Form 6476-ME, "Modification/Expenditure of Nuclear Materials", and returns a copy to the using organization.

8. Updates the Sandia and MMMSS computer records in accordance with the procedures set forth in earlier Sections 3.2 and 3.3 of this chapter. 
Responsible Organization

Safeguards and Technical

Security Division

(Accountability Clerk)
Action

9. Files the IAF of expended nuclear material approved by the NM Manager in the "Current Month's Business" working file.

10. Balances the working file against the updated computer records daily.

10.1 Forwards adjustments in a monthly cost report and balance sheet code report, described in Section 4, Step 14, to the Property Accounting Division for financial reporting.

11. Files the IAF of expended nuclear material and the expenditure memorandum in the IAF file.

\section{2 procedures for the Accountability of Nuclear Material Disposals}

Scrap and/or excess material residues recovered by using organiza-

i ions are transferred to the Nuclear and Explosives Materials Control

Section in accordance with the procedures set forth in Sections 7 and 8 , Chapter $v$, and are disposed of accurding to the instructions issued by DOE/ALO. Although Sandia National Laboratories receives a blanket authorization from DOE/ALO to bury quantities of non-SNM scrap during the fiscal year, notification of disposal is still required to be submitted to DOE/ALO and to the NMSS.

Responsible Organization

Safeguards and Technical Security Division (NM Manager)
Action

1. Receives Form SA 6476-ME, "Modification/Expenditure of Nuclear Materials" (Exhibit 17, Chapter X), from the using organization reporting the actual quantities of materials expended and the amount of materials converted to scrap and/or excess material residues.

2. Checks the files for the disposition authorization from DOE/ALO.

3. Prepares Inventory Adjustment Form ( IAF). 
Responsible urganization

Safeguards and Technical

Security Division

(NM Manager)

Safeguards and Technical

Security Division

(Accountability Clerk)
Act 201

4. Receives the completed burial form prepared by the Nuclear ind Explosive Materials iontrol seztion on Form SC 2040-L, "Radioactive and Toxic Material Disposal" (Exhibit 14, Chapter VIII). For rsidue' buried, comnletes and signs IAF, and gives $1:$ accountatility clerk.

5. Prepares Form DoE-741, "Nuclear Material Transaction Report" (Exhibit 15, Chapter VIII), transferring the material to $t h$. burial ground (RIS:VLA).

6. Uprates the Sandia and NMMSS computer records in accordance with the procedures set forth in Sections 3.2 and 3.3 .

7. Distributes a copy of the FGim DOE-74] to DOE/ALO (RIS: AAA).

8. Files the completed Form DOE-741, the burial furm, and the IAF from the using organization in the "Current Month's Business" working file.

9. Balances the working file against the updated computer records daily.

10. Files the Form DOE-741 numerically in the 741 shipping file.

11. Files the IAF in the IAF file.

\subsection{Procedures for the Accountability of Nuclear Material Decays}

Adjustments to the quantities of accountable nuclear materials recorded in the inventory are made based on material decay. Material decays are calculated for Material Type 83 materials whenever tibse materials are removed from the inventory by shipment to another facility. Decays are also caiculated periodically for quantities of the other materials remaining in the inventory. Materials for which decay must be calculated along with the decay rates and reporting units used in thesi calculations are included in Table VI-I. 
TABLE VI-I

Summary of Data Used in Material Decay Calculations

\begin{tabular}{|c|c|c|c|}
\hline $\begin{array}{c}\text { Material } \\
\text { Typu } \\
\end{array}$ & Jaterial & $\begin{array}{c}\text { Decay } \\
\text { Factor/Month } \\
\end{array}$ & $\begin{array}{c}\text { Reporting } \\
\text { Units } \\
\end{array}$ \\
\hline 44 & Americium-24l & $0 .(11) 01331$ & Crams \\
\hline 45 & Americi um-243 & 0.01701331 & Grams \\
\hline 47 & Berkelium-2149 & 0.065885 & Micrograms \\
\hline 48 & Californi um- 252 & 0.021896 & Micrograms \\
\hline 50 & Plut on ium-240 & 0.004011 & Grams \\
\hline 83 & Plutonium-238 & 0.0006583 & Grams (to tenths) \\
\hline 87 & Trit i um & 0.004687 & Grams (to hundreths) \\
\hline
\end{tabular}

For all shipments of these materials, an accountability clerk in the Safrguard: and Technical Security Division calculates and reports the decay through the last reporting period before shipment. For all receipts of these materials, the last decay date is reported on the 741 transfer doctment. In the event that a shipment to Sandia Laboratories is in transit at the reporting, date, no decay is reported until the close of the month in which the materials are actually received.

Adjustments to the remainder of the nuclear material inventory are made periodically based on material decay whenever accumulations of accountabl: cuantities of the designated matorials have decaydu Thes" calculations are made by an accountability clerk in the Safeguards and Technical Sicurity Division and recorded on The Inventory Adjustment Form $(I A F)$.

Responsible Organization

Safeguards and Technical Security Division (Accountability Clerk)
Action

1. Monthly, on terminal screen IAF 051 titled "Calculate Decay", in puts the IAF no., date, case no., inaterial type, and action code " $M$ " which calculates the decay for all serial numbers within the material type. 
Responsible Organization

Safeguards and Technical

Security Division

(Accountability Clerk)
Action

1.1 Programmatically decreases the element and isotope weights by the amount of decay.

1.2 Generates a listing of serial numbers decayed, amount of decay, and adjusted inventory weights by serial number.

2. Programmatically records the decay in the corporate ledger.

3. Transmits updated data to DOE/ALO and NMMSS in accordance with earlier Sections 3.2 and 3.3

4. Files the completed IAF forms.

\subsection{Procedures for the Accountability of Internal Transactions}

In order to maintain the accuracy of the computerized nuclear material data base in a timely manner, accountability clerks in the Safeguards and Technical Security Division update the computer records for all transactions involving changes in the information contained in the data base. Such changes may involve changes in location or accountability (movements, transfers between accountable MBA's, authorized retention periods for stored materials, etc.) as well as changes in material quantities (resulting from assembly/disassembly or other modifications, expenditures, etc.). Transfers are reviewed for program application and DOE project number changes made as required.

Using orfanizations inform the Safeguards and Technical Security Division of changes in nuclear material information by means of various forms and memoranda. Form SA 2042-D "Nuclear and Radioactive Material Transfer" (Exhibit 6, Chapter $X$ ), documents all transfers of materials between accountable MBA's, and Form SA 6476-A, "Record of Assembly/ Disassembly and Movement" (Exhibit 9, Chapter $X$ ), documents the assembly or disassembly of items in which nuclear materials are incorporated. In addition, using organizations supply memoranda to the Safeguards and 
Technical Security Division to document material expenditures or other changes in the status of materials in their possession.

Accountability clerks in the Safeguards and Technical Security Division input internal tranaction data via the appropriate terminal screen, depending upon the type of adjustment to be made, in accordance with the procedures specified in Section 3.2 for updating Sandia's computer records. Transfer documents, assembly/disassembly forms, and memoranda from using organizations are then retained in appropriate files in order to comply with DOE and Sandia audit and retention requirements. 


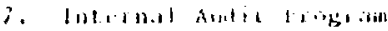

To assure chat material control procedures are effective and that these procedures are being complied with in daily operations, the Safeguards and Technical Security Division administers a continuous internal audit program. Internal audits provide information on the adequacy and effectiveness of established policies and procid: es and on tic retions necessary to improve the nuclear materials managenent program.

Audits are performed bi-monthly in MBAs having SNM except for Area $V$ which is inventoried monthly, quarterly or semi-annually in Miss with nolim SNM materials, and an annual inventory of all MBAs in the month of February. Utilization and storage reviews are also performed during thes" internal audits to identify excess materials and to assist in the optimization of nuclear material inventories.

\subsection{Proc adures for the Performance of Internal Audits}

Responsible Organization

Safeguards and Technical Security Division (Internal Auditor)
Action

1. Verifies the custodian's "Authorization for Redelegation".

2. Conducts a physical inventory verification.

3. Checks material labels for legibility.

4. Checks that "Radioactive" and "Nuclear Material" caution labels have been properly affixed to storage cabinets and containers.

5. Checks scale and balance certification dates.

0 . Verifies the weights of arbitrarily selected items. 
7. Reviews the custodian's records maintained in support of the inventory, including material transfer forms (both incoming and outgoing), material locations, and assembly/disassembly activity.

8. Reviews material utilization with respect to the programs being performed.

\section{I For material in an inactive status, either a justification for retention or a declaration of excess is obtained.}

9. Reports MBA audit results to the Custodian of the using organization, including total items audited, discrepancies found, general comments, and an overall assessment of "acceptable" or "unacceptable."

9.1 Discrepancies reported will include missing items, missing serial-number identification, incorrect serial-number identification (as determined from the master file computer listing), modified and/or scrap materials which are not identified individually or not associated with the original materials, missinf identification of SS parts in assemblies, materials inventoried which are accountable to another MBA, and materials inventoried which were previous!y reported as expended in tests.

9.2 Corrections will be provided by the internal auditor to the accountability clerk for updating inventory records and the auditor verifies corrections made. 


\section{Inventory}

Each material balance area (MBA) is scheduled by the Safeguards and Technical Security Division, for a monthly, quarterly, semiannual, or annual inventory -- depending upon the type and quantity of material. Inventaries are conducted by Safeguards and Technical Security Division personnel, accompanied by the MBA custodian/alternate, using bar code readers. When the inventory is completed, the data inventoried are transmitted from the bar code memory unit to the cumputer for reconciliation with the master file. A printout results from the reconciliation which lists errors, or a statement that no errors exist. The irrors are investigated and corrections retransmitted until the MBA is reconciled. Following the inventory reconciliation, a computer listing of the material charged and inventoried is forwarded to the MBA custodian.

\subsection{Procedures for the Performance of Inventories}

\section{Responsible Organization}

Safeguards and Technical Security Division (Internal Auditor)

Safeguards and Technical Securicy Division (Inventory Team)
Action

1. Maintains an MBA checklist for each month, indicating which MBAs are scheduled for inventory.

2. Telephones the MBA custodian to arrange and confirm an inventory date and time.

3. Before each inventory, removes fully charged memory pack(s) from the battery charger/transmitter unit in the Safeguards and Technical Security Division.

4. Upon arriving at: MBA location:

4.1 Attaches memory pack to the bar code reader keyboard.

4.2 On keyboard, presses (1) clear key, (2) info key, and then (3) holds down enter key until numbers 8044 appear in upper left hand corner of the display area and the number 0 appears in the lower right hand corner. 
Responsible Organization

Safeguards and Technical

Security Division

(Inventory $T \cdot a m$ )

Material Balance Area

(Custodian/Alternate

Custodian)

Safeguards and Technical

Security Division

(Inventory Team)
Action

4.3 If these numbers do not appear, repeat steps (1) thru (3) until the memory pack is cleared.

5. Directs the inventory team to the location of all items for which the MBA is accountable.

6. Enters data as follows:

6.1 Press clear key.

6.2 Press info key once and one small letter o will appear in the display area.

6.2.1 Following letter o, enter MBA number and press the enter key.

6.2.2 This step is repeated each time a new memory pack is inserted, or a new MBA is being inventoried.

6.3 Press info key twice and two small letter os will appear in the display area.

6.3.1 Following the two letter os, enter the buildin: number and press the encer key.

6.3.2 This step is repeated each time a different building within the sane MBA is inventoried.

5.4 Press info key three times and three small letter os will appear in the display area.

6.4.1 Following the three letter os, enter the room number (if applicable) and press the enter key.

6.4.2 This step is repeated each time a new room within the same building is invenroried. 
Safeguards and Tec nical Security nivision (Audit Team)

\subsection{Proceeds to read each har coded serial number on the ilentifica- tion label with the bar code light pen.}

7. Visually inspects each accouncable item during the inventor, process and compares it with the identification lat') (excepl sealed containers in storage and gealed cards and safes in Area V which have only a "Father" card serial number to read).

9. Upon completion of the inventory removes memory pack(s) from the bat code keyboard and returns them to the Safeguards and Technical Security Division.

9. Inserts the memory pack(s) in the battery charger/transmitter (unit 27 or 28 ).

10. Signs on at terminal and selects inventory menu.

11. Enters No. 4 (inventory entry memory pack).

11.1 Input number of memory pack(s), unit being used to transmit, and whether the input is initial or an update.

11.2 A message will appear on the screen to reply to the console request.

11.3 After replying to the console, press the transmit button on the battery charger/transmit t $t$.

11.4 After data from the memory pack have been read into the computer an error listing will be generated on the 1 ine printer.

12. On the terminal, inters No. 7 on the inventory menu (physical inventory report). This generates a 1 isting of all items entered from the memcry pack. 
Safeguards and Technical Security Division

(Audit Team)
13. On the terminal, enters No. 6 on the inventery menu finvintory reconciliation).

13.1 The line printor prints a listing of any discrepaneits found in the invontory.

13.2 If Lhere are no disirepancirs. the printout will s:at, "No Frrors Foumd in MBA ."

13.3 if discrepancios are found, verification a. remtering of thr items in orror munt be accomplishert.

13.4 Following verification, patr may be made either manually nn the terminal, or through tho memory park.

14. In the tormianl, ruters Nis. 5 ( I muentory Entry (oanu,zl)) fur l'pdat" ir Initial ontry.

14.1 Manual ontry is nurmally an Update and adils data to the iiln.

14.2 If there are ingsting invelutery dat $a$ on fill and the liutial ontry is selected, al invencurv data will be last.

14.3 Changes may be made globally o. hy individual serial number for MBA, bujlding, and room numbirs.

15. If discropanides still wist following stop 14, repeat Steps 13 and 14 until the inventory is reconciled $a: d$ a priniout is received from the line printer stating "*o Errors Found in MBA "

16. Generates inventory reports as MBAs are recolni ilad, and forwards th the appropriata eustodian. 
17. Files all copies of the reconcili-

Safeguards and Technical Security Division (Auditor)

Off-Site Material Balance. Area (Custodian/Alternate Custodian)

Safeguards and Technical Security Division (Accountability Clerk)
17. Files all copies of the reconcil
ation output for audit purposes.
18. Telephones the custodian/alternate of off-site MBAs to verify serial numbers of material at the site
19. Confirms, in witing, the serial numbers of material at the site.
20. Enters data received on the keyboard of the bar code reader and follows procedures in steps 9 though 17.

\subsection{Supplemental Inventory Instructions}

When DOE audits are scheduled, the Safeguards and Technical Security Division issues a memorandum to all custodians with special instructions stating the period of time required for the DOE physical inventory and requesting that materials not be noved during this period unless absolutely necessary.

The Safeguards and Technical Security Division conducts internal audits continually throughout the year. Periodically, a statistical random sampling technique is used on all of the MBAs and, once a year, a 100\% physical inventory of each MBA is conducted. 


\section{DOE Audits}

The DOE conducts surveys or inspections periodically to assure that effective control of nuclear matrials is maintained and that the management of nuclear materials is proper. DOE Order 5630.2 provides guidelines, procedures, and instructions which are applicable to the conduct of these surveys. As stated in that order:

\footnotetext{
"The nuclear material survey may be considered to consist of three major phases of activity: procedural review, records audit, and inventory verification. These th ee phases are a part of each survey whether the survay is to evaluate safeguards control or both safeguards control and inventory management."
}

DOE/ALO reviews the safeguards control and management of nuclear materials at Sandia during two annual surveys, described below.

\subsection{Safeguards and Security Survey}

DOE/ALO conducts annual surveys of Sandia's safeguards control programs and practices. A DOE/ALO evaluation team performs an onsite inspection of Sandia's material inventory, records, and procedures with the main objective being the reconciliation of the records inventory with the physical inventory. The records audit evaluates the results of the data generating, collecting, reporting, and recording procedures in order to determine the quantities of material that should be on hand. Inventory verification consists of independently testing the physical inventory in order to ver fy the quantities of material actually on hand.

Following the onsite inspection, the DOE/ALO evaluation team issues a survey report which includes the basis for acceptance (or nonacceptance) and certification of the inventory, an evaluation of control indicators (such as normal operational losses, material unaccounted for, shipperreceiver differences, etc.) regarding the effectiveness of safeguards control, and recommendations for actions necessary to correct deficiencies disclosed during the survey. 


\subsection{Nuclear Materials Management Appraisal}

DOE/ALO conducts annual appraisals of Sandia's nuclear materials management programs and practices. The appraisal is a formal review of major aspects of Sandia's materials management activities by a DOE/ALO evaluation team, beginning with an analysis of the records at DOE/ALO which document material movements, utilization, scrap generation, scrap recovery, and overall inventory size. Upon request, Sandia submits a material utilization review (Exhibit 2, Chapter VIII) Lo DOE/ALO, indicating the current status of nuclear materials in the inventory. The appraisal concludes with an on-site examination of Sandia's nuclear materials activities by the evaluation team.

Following the on-site inspection, the DOE/ALO evaluation team issues a report summarizing the findings of the appraisal, exemplary practices or deficiencies noted, and proposed follow-up actions. 


\section{Accountability Reports}

DOE requires that inventory balance reports and $74 \mathrm{l}$ transfer data plus adjustment data which affect the inventory be reported on a frequency schedule ranging from daily to semiannually as described in the following description of reports.

\subsection{External Reports}

The following computer-generated reports are prepared in compliance with DOE requirements:

741-Nuclear Material Transaction Report -- Transmission via Sncuet is made daily to DOE/ALO and NMMSS/Oak Ridge. Data transmitted update the data bases at both locations regarding receipts, shipments, and inventory adjustments.

749-Internal Project Transfers -- Transmission via Sacnet is made daily to NOE/ALO and NMSS/Oak Ridge. Datn transmittrd update the data bases at both locations to refiect chanews in material utilization and assigument of the corresponding. project number.

\section{End-of-Month Balances:}

MT/ALA -- Inventory balances by material type, element weight, and isotope weicht are submitted monthly to DOE/ALO. Table VJ-JIT sumtarizes the major reporting requirements:

MT/VLA -- Inventory balances by material type, element weight, and isotope weight are submitted monthly to DOE/ALO.

ER/VLA -- Inventory balances by enrichment range, element weight, and isotope weight are submitted monthly to DOE/ALO and MMSS/Oak Ridge. 
Project Number -- Inventory balances by project number, element weight, and isotope weight within material type.

Status of Inventory -- Computer-generated reports are submitted monthly to DOE/ALO and quarterly to the NMMSS in Oak Ridge in the format of Form AL-974-A, "SS Material Quarterly Composition of Ending Inventory" (Exhibit 3, Chapter VIIT). These reports provide a summary of the invontory as of the dats reported to DOF project number, material type, corichment range cods, composition of andins invantory conde. flrment wright, and isotope woight.

Matcrial Status Report (MSR) - Computer-goneratod material atalu: reports, sipned by a corporate official, are submicted semiannually in April and Octobne LO DOF/ALO and to DOF: headquarters in Washington, DC in the format of Form AL-7I\}, "Material Status Report--Summary" (Exhibit 4, Chapter VIil). These reports provide a summary by material typo of beginning inventory, recripts by Roporting Identifiration Symbol (RIS), removals by RIS, other expendituris or losses (e.e., decay, normal operational losses, routine test, material unaccounted for, etc.) and ending inventory for both the current month of the report and for the ycar to date for the 6-month period ending in the month of the report, including negligible nuantitifs reported with asterisks. DOE Order 5630 provides specific guidelines for the preparation of the report. 
TABLE VI-I I

Accountability Reporting Requirements

\begin{tabular}{|c|c|c|c|}
\hline Report & Facility & Frequency & Report Mode \\
\hline 741 & $\begin{array}{l}\text { DOE/ALO } \\
\text { GDP/Oak Ridge } \\
\text { Addressee }\end{array}$ & Daily & $\begin{array}{l}\text { Sacnet } \\
\text { and/or } \\
\text { Hard copy }\end{array}$ \\
\hline 749 & $\begin{array}{l}\text { DOE/ALO } \\
\text { GDP/Oak Ridge }\end{array}$ & Daily & Sacnet \\
\hline MT & DOE / ALO & Monthly & Sacnet \\
\hline MT/VLA & DO $\Xi / A L O$ & Monthly & Sacnet \\
\hline ER/VLA & $\begin{array}{l}\text { DOE/ALO } \\
\text { GDP/Oak Ridge }\end{array}$ & $\begin{array}{l}\text { Monthly } \\
\text { Monthly }\end{array}$ & $\begin{array}{l}\text { Sacnet } \\
\text { Sacnet }\end{array}$ \\
\hline Project No. & $\mathrm{DOE} / \mathrm{ALO}$ & Monthly & Sacnet \\
\hline SOI $(\operatorname{COE} I)$ & $\begin{array}{l}\text { DOE/ALO } \\
\text { GDP/Oak Ridge }\end{array}$ & Quarterly & Sacnet \\
\hline MSR & $\begin{array}{l}\text { DOE/ALO } \\
\text { US DOE/OSS }\end{array}$ & Semiannually & Hard copy \\
\hline
\end{tabular}

\subsection{Internal Computer-Generated Reports}

A number of internal reports and listings are generated periodically in order to assist the Accountability Clerks to account for Sandia's nuclear material inventory and in the preparation of reports to the DOE. These listings are generated by sorting the computerized accountability records in various ways to provide information in the most effective format for specific purposes. 


\section{Computer Listings}

Each item of accountable material in Sandia's computerized nuclear material data base is identified by a unique serial number which is the primary file identification control field for the item. Information contained in the data base for each item of accountable material includes:

- Serial Number

- Descriptor

- Country Control Number

- Owner MBA

- Ownet RIS

- Weighable Flag

- Level Entity

- Part Security Classification

- Sla Program Number

- Storage rotention Date

- Item Description

- Disposition Status

- Accountable Date

- Building Number

- Room Number

- Accountable MBA

- Container Number
- Container Type

- doE Project Number

- Material Type

- Inventory Date

- Random Inventory Date

- Owner Code

- Composition Code

- Item Cost

- RIS Code

- 741 Document Number

- Element Weight

- Decay Date

- Isotope Weight

- Net Weight

- Weight Percent Isctcpe

- Enrichment Range

Information in the data base is sorted in various ways to generate reports and listings for use by the Safeguards and Technical Security Division and the Nuclear and Explosives Materials Control Section in the management and physical control of accountable nuclear materials. 


\section{CHAPTER VII}

\section{SAFEGUARDS}

\section{General Requirements}

Because of the strategic value and inherent hazards associated with nuclear materials, stringent satguards and security requirements are imposed on the storage, handling, processing, and utilization of thesi. raterials. Using organizations having nuclear materials in their cuscoly: are responsible for maintaining adequate physical controls and for complying with established security procedures to protect against theft, diversion, sabotage, or vandalism. These procedures are described in varius nof, Federal, and Sandia reference documents, including:

- DOF Manual Chapter 2401 -- Physical Protection of classified Matter and Information.

- DOE Order 5632.2 -- Physical Protection of Special Nuclear Material.

- DOE Manual Al Chapter 24XA -- The DOE Transportation Safeguards System.

- Code of Federal Regulations (CFR), Title 49, Parts 100 thru 189 -- Hazardous Materials Regulations.

- Sandia Laboratories Engineering Manual (Chapters 2.11 "Nuclear Explosive Safety", and 2,11-1 "Contro: of Nuclear Explosive-Like Assemblies (NELA)."

- Sandia Laboratories Security Handbook.

- SLI 6950-2 -- Shipments.

- Slt 6950-4 -- Movement of Classified Materials. 
Additional procedures to establish safety standards associated with radioactive and nuclear materials are decribed in other reference documents, including:

- DOE Manual Chipter 0504 -- Operational Safety Program Appraisals.

- DOE Manual Chapter 0524 -- Standards for Radiation Protection.

- DOE Manual Chapter 0529 -- Safety Standards for thr Packaging of Fissile and Other Radioactive Materials.

- DOE Manual Chapter \$530 -- Nuclear Criticality Safety.

- SC-M-70-889 -- Sandia Laboratories Manual for Industrial Safety, Fire Prevention, and Environmental Health.

- SLI 200] --industrial Safety, fire Prevention, and Environmental Health.

- Sll 2048 -- Nuclear Explosive Safety.

- SL1 2047 -- Nuclear Criticality Safety.

- Sli 1030-9 -- Sandia Nuclear Criticality Safety Committee.

The procedures described in this chapter are intended to provide specific information on safeguards and security requirements for special nuclear materials (SNM) as a supplement to the reference documents cited above. Source and other designated nuclear materials are handled and stored in accordance with procedures stipulated by the Environmental Health Department and the Physical Security Standards and Investigations Division. Category I and II quantities of SNM require special security protection. Special security procedures are also established for any roam, building, or portion of a building in which accumulations of SNM (by one or more MBAs) are of Category I or IT quantities.

Table VII-I includes a listing of materials and quantities by category. 
The Safeguards and Technical Security Division assumes the responsibility for informing using organizations of the proper classification of SNM, and both the Safgeguards and Technical Security Divisi in and the using organization remain aware at all times of the quantities and locations of SNM accountable to the authorized MBAs. In the event that any accumulation of SNM within a specified location exceeds the quantities defined in Table VII-1, either the Safeguards and Technical Security Division or the using organization immediately notifies the Health Physics Division and the Physical Security Standards and Investigations Division of this condition to provide for adequate safety and security protection.

Since personel involved in operations using radioactive and nuclear materials are expected to know and comply with all safeguards requirements in the relevant reference documents, descriptions of those requirements have not been duplicated here.

Table VII-1

Physical Protection Categorization of Nuclear Material

\begin{tabular}{|c|c|c|c|c|}
\hline $\begin{array}{c}\text { Special Nuclear } \\
\text { Material }\end{array}$ & $\begin{array}{c}\text { Category } \\
1 * \\
\end{array}$ & $\begin{array}{c}\text { Category } \\
\text { II* }\end{array}$ & $\begin{array}{r}\text { Category } \\
\text { III-A** } \\
\end{array}$ & $\begin{array}{c}\text { Category } \\
\text { III-B }\end{array}$ \\
\hline Plutonium & $\begin{array}{l}2 \mathrm{~kg} \text { or } \\
\text { more }\end{array}$ & $\begin{array}{l}400-1999 \\
\text { grams }\end{array}$ & $\begin{array}{l}220-399 \\
\text { grams }\end{array}$ & $\begin{array}{l}1-219 \\
\text { grams }\end{array}$ \\
\hline $233_{U}$ & $\begin{array}{l}2 \mathrm{~kg} \text { or } \\
\text { more }\end{array}$ & $\begin{array}{l}400-1999 \\
\text { grams }\end{array}$ & $\begin{array}{l}220-399 \\
\text { grams }\end{array}$ & $\begin{array}{l}1-219 \\
\text { grams }\end{array}$ \\
\hline $\begin{array}{l}{ }^{235} \mathrm{U} \text { (Contained in } \\
\text { urani um enriched to } \\
20 \% \text { or more) }\end{array}$ & $\begin{array}{l}5 \mathrm{~kg} \text { or } \\
\text { more }\end{array}$ & $\begin{array}{l}1000-4999 \\
\text { grams }\end{array}$ & $\begin{array}{l}350-999 \\
\text { grams }\end{array}$ & $\begin{array}{l}1-349 \\
\text { grams }\end{array}$ \\
\hline $\begin{array}{l}235 \mathrm{U} \text { (Contained in } \\
\text { urani um enriched to } \\
\text { less than } 20 \% \text { ) }\end{array}$ & - & - & - & $\begin{array}{l}\text { All quantities } \\
\text { above } 0.99 \\
\text { grams }\end{array}$ \\
\hline $\begin{array}{l}\text { :If plutonium or } 23 \\
\text { shall be multiplie }\end{array}$ & $\begin{array}{l}\text { s combine } \\
2.5 \text { to }\end{array}$ & $\begin{array}{l}\text { with }{ }^{235} \mathrm{U} \\
\text { ive at the }\end{array}$ & $\begin{array}{l}\text { the amount } \\
\text { limits she }\end{array}$ & of $\mathrm{Pu}$ or ${ }^{233 \mathrm{U}}$ \\
\hline
\end{tabular}




\section{Storage of SNM}

Due to their possible theft by terrorist groups, their intrinsic value, and the hazards which they pose to the public health, special nuclear materials (SNM) require diligent physical protection and rigorous administrative controls. During nonoperational hours and at all other times when not in use, SNM (including scrap) is stored in approved repositories, unless such an arrangement is not feasible because of size, weight, or continuous experiments. When such an arrangement is not possible, the responsible supervisor consults with the Safeguards and Technical Security Division and the Physical Security Standards and Investigations Division to provide for appropriate safeguards and security protection. For Category I quantities of special nuclear materials, approved repositories consist of vaults or vault-type rooms within a Material Access Area (MAA) which is, in turn, located within a protected area. A protected area is an area which is enclosed by physical barricr. and which is subject to access controls established by the Physical Security Standards and Investigations Division, approved by the Health Physics Division, the Planning Division, the Safety Engincering Division and administered by the Safeguards and Security Department. An MAA is an area which is located within specifically defined regions inside a protected area and to which access is restricted to specified authorized individuals. Other prescribed areas may serve as approved repositories for Category I quantities of SNM, but such areas require 24-hour surveillance by two guards as well as special advance security approval and procedures.

Category II quantities of SNM are also stored in approved repositories. Approved repositories for quantities of Category II consist of DOE-approved, intrusion-alarmed containers, vaults, or vault-type rooms with access restricted to specified authorized personnel only.

Less than Category II quantities of SNM are stored either in a locked DOE-approved security container (safe-file cabinets or safes) or in a locked room located within a protected area. 
SNM scrap (which is packaged in appropriate containers) is stored in a se. ur ity-aproved, separacely fenced area within a larger protected : $x+1$.

All zpproved repositories should provide a stendiary (morepency) means of egress (in conjunction with rxist ing building codrs) and should b. anstruted in such a manner that there is ne puseibilile uf flonding

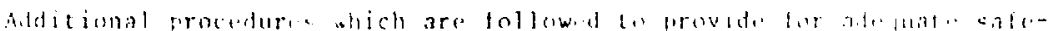

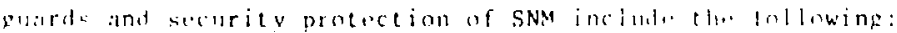

- The uperating supervisor of an YMa providea the. $\because$ aleguaros and security Department with a list ll! amployeses who are aluthorized to have acest to the areal linder normal conditions, aceess onntrols to th. WA its administired by the operating orpanizat ion.

- Sritcen records are maintained of all parsons mot sn th. access list who onter the MAA and of all persons who enter the area during nonoperational hours.

- Personal vohicles are excluded from muthetod arias dnd MAA.

- Covernment vehicles are admitted to protected arias or YAAs only when on official busintess and optratid !: a ?cleared drjuer.

- All parkages, bricicascs, and simjlar items as well as all venicles ore subject to search upon entering a protected area nnd upon leaving an whl.

ivelear materials are issupd to using organizations onl upon evidence af adequate approved storage within the area to wh h tha daterials will be assigned, and criticality-safe conditions arr courdinated Linrough the Enyironmental Health Department. Custodians ar.: responsible for ensuring adequate safeguards for all personnel involved in the 
handling and storage of nuclear materials by labeling materials as to the type of material, necessary precautions, and security classification. Personnel handling nuclear materials observe all health and safety procedures stipulated in the Environmental Health section of SC-M-70-889, "Sandia Laboratories Manual for Industrial Safety, Fire Prevention, and Environmental Health." 


\section{SNM in Use}

When in use or in process, Category I and I quantities of SNM are kept under surveil'ance by at least two persons, one of whom must have a $Q$-clearance and the other at least an " $S$ " or " $L$ " access authorization. Category I quantities of SNM are used or processed only within specified areas, and access to these areas is 1 imited to those personnel required to perform official duties. Category II quantities of SNM are used or processed snly within a protected area. Less than Category II quantities of SNM also require adequate safety and security protection, and the additional procedures described in Sectior 2 above would normally be followed. 


\section{On-Site Shiprents of SNM}

The movement of special nuclear materials between Sandia National Laboratories Security areas (protected areas) is arranged in advance by the Nuclear and Explosives Materials Control Section with the desk lieutenant in the Safeguards and Security Department. Category I and I quartities of SNM must be transported in either locked and sealed safe secure trailers (SST) or enclosed lockable vehicles equipped with a twoway radio and driven by Q-cleared operators. To ensure that the concept of two-person access control is followed, DOE/ALO requires that a method of double-locking be established to secure the cargo area of vehicles which transport Category I and II quantities of SNM between security areas. The SNM vehicle is equipped with a second hasp and two DOEapproved combination padlocks to fulfill the double-locking function. One of these 1 ks will be maintained by the Nuclear Materials Control section, and the other will be maintained by the desk lieutenant of the Safeguards and Security Department. Each organization will be responsible for controlling the lock combination of their respective locks and for changing those combinations when compromise is suspected. The two-lock system will be applied at all times when Category I and I quantities of SNM are being transported. The two locks will be supplied by the respective organizations at the time that the local shipment of Category I and II quantities of SNM is scheduled, and each of the organizations will also provide one individual to escort the shipment.

Local shipments of Category I quantities of SMM are also escorted by two separate vehicles manned by armed personnel from the Safeguards and Security Department. The security lieutenant in charge of this security team is also responsible for ensuring that the double locks are in place and secured before transport.

Less than Category II quantities of SNM must also be transported in an enclosed lockable vehicle equipped with a two-way radio and driven by a Q-cleared operator, but these movements do not require a security escort. 
Inventory items that cannot be physicaily located or accounted for by Ho MBA custodian or the Safeguards and Technical Security Division audit team are jmmediately reported to the Security Dperations Division.

The Security Operations Division conducts an investigation and raports to the Safeguards and Technical Security bivision. Tf the material has not been found, the Snfeguards and technical Ser rity Division telephones the Safeguards and Security Department Manager, Director of Industrial Relations and Property Protection, DOE/ALn Sandia Area Office Managir, and DOE/ALO Safeguards and Security Division director to report the Joss.

The telephone report is followed within 24 hours by confirmation in iritina by teletype, memorandum, or report which contains:

- Location where missing material was last scon

- Description by chemical and physical form

- Material type and quantity

- Classification

- Any indjcatior of willful diversion

- Dollar value

- Circumstances under which loss was detected

- How material may have left facility lacition

- Sceps being taken to locate missing material

- Planned corrective action. 


\section{Special Procedures for Access to the Manzano Storage Structures}

In conjunction with nuclear material operations at Sandia National Laboratories, the Nuclear and Explosives Materials Control Section utilizes five structures at Manzano Base for the storage of accountable nuclear materials. Two of these structures (Structures 7055 and 7063 ) are used for the storage of special nur" ar materials (SNM) and are designated as Priority "A" security structures. he other three structures (Structures 7046, 7047, and 7049) are used for the storage of other nuclear materials and are considered to be nonpriority structures. Access to all of these storage struetures is restricted to the authorized in ividuals specified on a 1 ist maintained by the Nuclear and Explosives Materials Control Section.

\section{6.l Procedures for Access to the Manzano Storage Structures During Operational Hours}

Responsible Organization

Nuclear and Explosives Materials Control Section
Action

1. Designates a group of three authorized employees to obtain access to the required structure.

1.1 One member of the group acts as the authorizing official, while the other two members open, enter, and secure the structure.

1. 2 Access to nonpriority structures requires only an authorizing official and one other authorized employee.

2. Calls CSC (the military control center), requesting authorization for access to the structure.

3. Provides his name, Sandia National Laboratories identification, slot number, structure number, approximate ETA, and the names and slot numbers of the two authorized employees who will enter the structures along with their respective key assignment responsibilities (upper or lower). 
Responsisle Organization

(Authorized Employee(s))

Nuclear and Explosives Materials Control Section (Authorizing official and Authorized Employee(s))

(Authorizing official)

(Authorized Employee 非)
Action

3.1 For nonpriority structures, only one authorized employee (other than the authorizing official) is required, since only the lower keys are needed.

4. Pick(s) up a set of keys for the security locks.

4.1 For Priority "A" structures, a set of keys for the upper locks is secured in a three-combination safe file in Building 801s, and a set of keys for the lower locks is secured in a three-combination safe file in Building 867 south.

4.2 For nonpriority structures, only a set of lower keys is needed to gain access to the structure.

5. Proceed to Manzano Base.

6. Upon arrival at the structure to be opened, calls CSC on the jack phone, provides his name, Sandia National Laboratories identification, slot number, number of the structure to be opened, identifies the two authorized employees who will enter the structure, and answers the daily code.

7. Hards the jack phone to the first authorized employee.

8. Provides his name, Sandia National Laboratories identification, and slot number, states that he is removing security from Structure \# , and answers the daily code.

9. For Priority "A" structures, hands the jack phone to the second authorized employee. 
(Authorized Employee \#2)

(Authorized Employee(s))

(Authorizing official)

(Authorized Employee(s))

(Authorizing official and Authorized Employee(s)

(Authorized Employee(s))
9.1 For nonpriority structures, only one authorized employee (other than the authorizing official) is required to enter the structure.

10. Provides his name, Sandia National l zboratorics identification, and slol number, states that he is removing security from Structure \# the daily code.

11. Open(s) the security lock(s) and proceed(s) into the structure.

11.1 For Priority "A" structures, one of the authorized employees opens the upper lock and the other opens the lower lock.

11.2 For nonpriority structures, only a lower lock is required to be opened.

12. Remains outside the structure and maintains radio and security contact.

13. Upon completion of the required operation, lock(s) and monitor(s) the door.

14. Calls CSC, using the same identification procedure as before and statilig that Structure \# is being. secured.

15. Wait until the alarm sounds, signi!ving that the structure is set up, and return to Sandia National Laboratories.

16. Return(s) the keys for the security locks to the appropriate safe Eiles. 


\subsection{Proceducs lur Access to the Manzano Storage Structures During Nonoperational Hours}

Wheneve: an open structure is found or damage to the protective system is discovered at one of the storage structures located at Manzano Bas: a athorized personnel from Sandia National laboratories are dispatchod to the structure and a physical inventory uf its contints is iah+n.

Responsible Organization

l'SAF (Manzano Baso)

C., $: r:: \because$ Disudalis anu

aprat inns Dippartment

- H....k i.j, itinant?

(Á, I ieut inant)

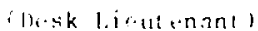

Nul liar and Explosivis yalerials control Soceion

Authorized fimployen'
Action

1. Notifics the desk ijollenant of Securite standards and operations Department that an alorm sustem

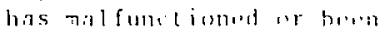
tampired with or that a strint ir.

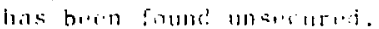

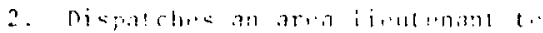
thi, $\ldots, n, \cdot$

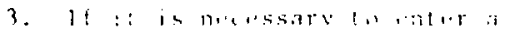
strut tur., notifits the desk

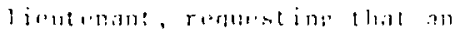
authorized emplave be sent t. the structure lo conduct at inconture of its soliente.

f. Calle and ut the autherized

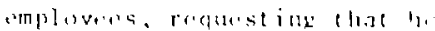
prosered to the reguirid structura th andulat a

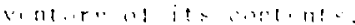

5. ['pun artival at Sandia National

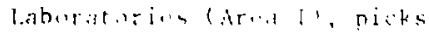

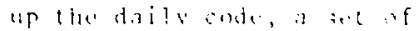
kis for the lower bok , and an anventore list : the $=t r w+1, r \cdot e$

h. Proweds to the structure, wher, la. je mel by the Sandia aroa lievtenant on the scene and one military eusrd (who remain at lha. site during the upening and $\because$ losing of the struc $\left(u^{2} r^{2}\right)$. 
Responsible Organization

Nuclear and Explosives Materials Control Section (Authorized Employee)
Action

7. Opens the structure in accordance with the procedures specified in Section 5.1.

7.1 For the Priority "A" structures (Structures 7063 and 7055), the area lieutenant provides the set of keys for the upper lock.

8. Conducts a physical inventory of the contents of the structure.

9. Secures the structure i 1 accordance with the pro:edures specified in Section 5.1 and returns to Sandia National Laboratorifs.

10. Returns the keys for the lower lock to the appropriate safe file. 
CHAPTER VIII

\section{COMPENDIUM OF RELEVANT NUCLEAR MATERIALS \\ MANAGEMENT AND CONTROL FORMS}

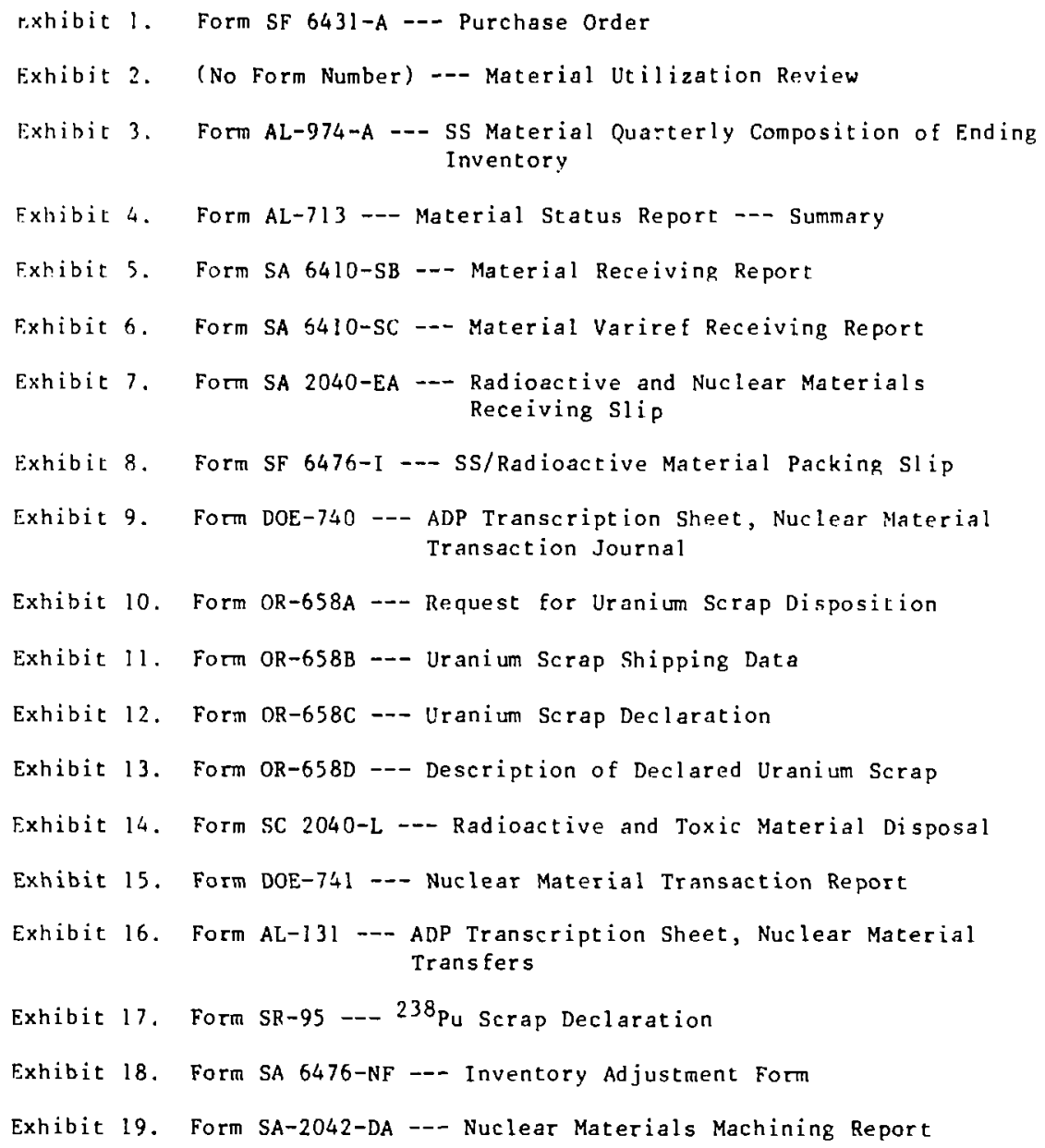


Exhibit 20. (No rorm Number) --- ADP Transcription Sheet, Sealed Source Registration Data

Exhibit 21. Form DOE-749--- ADP Transcription Sheet, Internal Project Transfers

Fohibit 22. Form sF 1811-ABA -- Telecommunication nata Messagr Form

Exhibit 23. Form Dot-284--- SS Material Transfer Receipt

F. xibit 24. Forn SA 2900-J --- Receipt for Classifild Information

Exhibit 25. Form SA 2042-D-- Nucleat and Radiaactive Material Transfer

Fshibit 26. Inventory Adjustment Form 
Form SF 6431-A --- Purchase Order

Purpose: $\quad$ To purchase radioactive and nuclear materials.

Prepared by: Purchasing Department.

Submitted to: Supplier.

A copy of this forn is also sent to the Safequards and Technical Security Division. 
Exhlbit 1

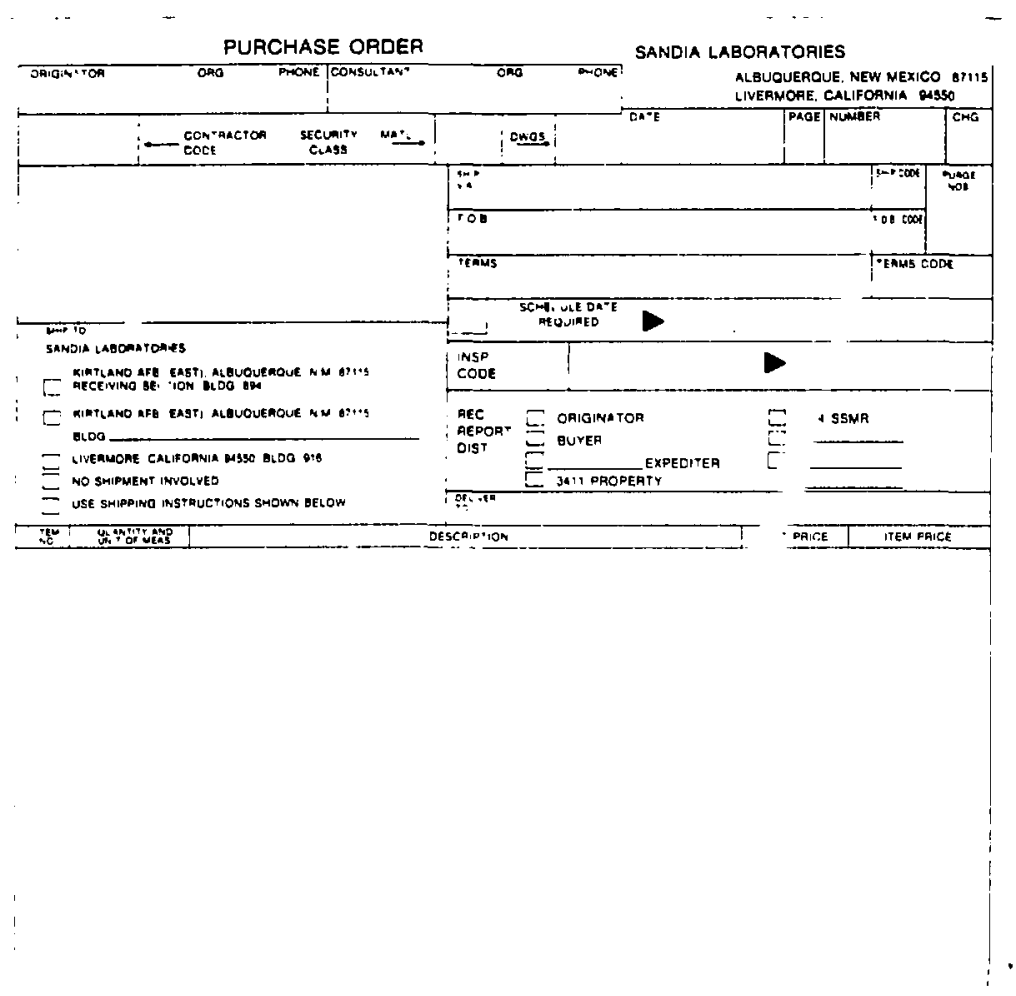

tOTAL PRICE

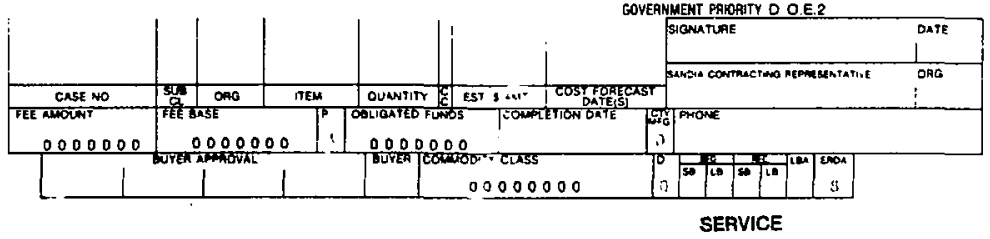

SEAVICE 
Material Utilization Review

Purpose:

To indicate the current status of nuclear materials in the iiventory.

Prepared by:

Safeguards and Technical Security Division.

Submitted to:

DOE/ALO. 
Exhibit 2.

WTERIAL JTILIZA:ION H:VI:

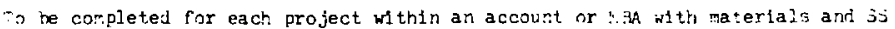
welgits ldent Ifled uder reporting requirements listed below.

troject $: 0$, arie $: 2 \pm$ le

Account. $: o$, and -1 tle

$\therefore$ a lerial

comment.

iraterlal

invient

ivpe

Quantity

itatus

ief.

Iype want1ty

vuant1ty jtatss

$\longrightarrow$

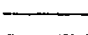

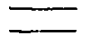

-

$\longrightarrow$

$\longrightarrow$
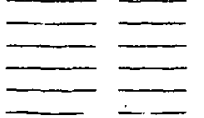

Hef.

Jorinents: (act] continuation sheets as necessary to $1: a l d d e$ sufficierl deta: : ,

Prepared By

Date:

Paterial aype

20 enriched araniua (1sotope)

50 Flutents (239) (element)

70 urantum:-?33 (1 sotope)

81 normal urantur

63 plutontun-?39 (15ntope.

F5 deuterium (as heavy water - $2 \times 5$ )

97 tritium

Status

1. In ise

2. Stored for Definite ise

3. Stored for to Anticlpated 'se

4. Serap
Reportine gequirements

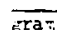

दrais

gran.

$\mathrm{kg}$

100 grams

$\mathrm{kg}$ to lenth $100 \mathrm{~kg}$

sram to hundredth 10 arans

Goanents

Identffy use, frequency, and disposition. itate expected lengli of time in storage and intended use. Detall the disposal plan. Identify recovery plans and rates and record length of time on inventory. 
Form AL-974-A4 -- SS Material Quarterly Composition of Ending

Purpose:

Prepared by :

Submitted to:
To provide a summary of the inventory by COEI 1 ine number within project number and material type.

Safeguards and Technical Security Division.

DOE/ALO monthily and to the NMMSS, Oak Ridge, quarterly. 
Exhibit 3.

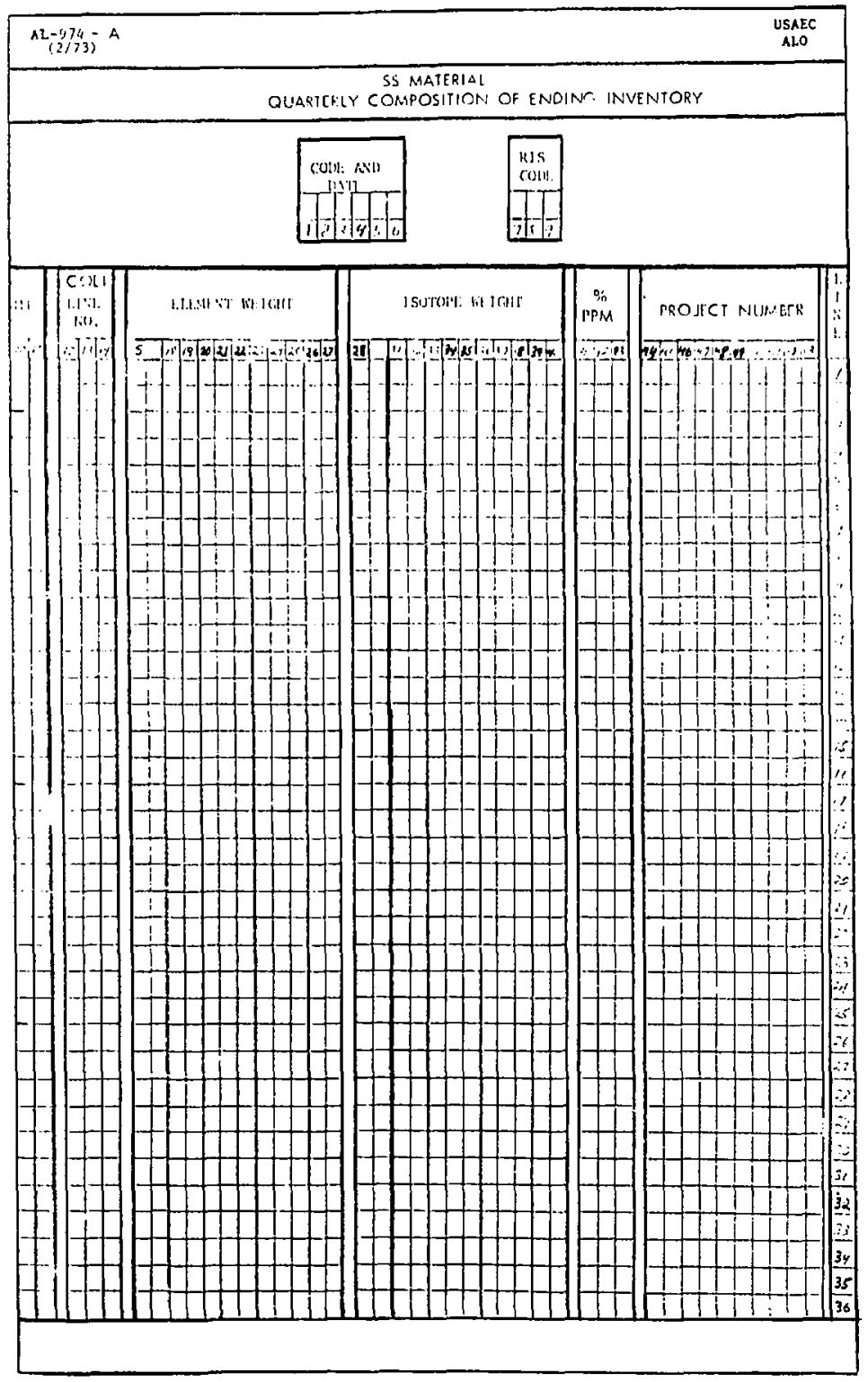


Form AL-713 -- Material Status Report - Summary

Pur pose:

To provide a summary by material type of receipts and removals.

Prepared by:

Safeguards and Technical Security Division.

Submitted to:

DOE/ALO and DOE Headquarters somiannually in April ard October.

$8-10$ 
Exhibit 4

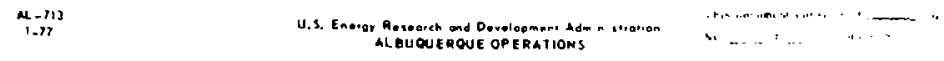

MATERIAL STATUS REPORT - SUMMARY

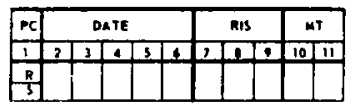

ADDRESS

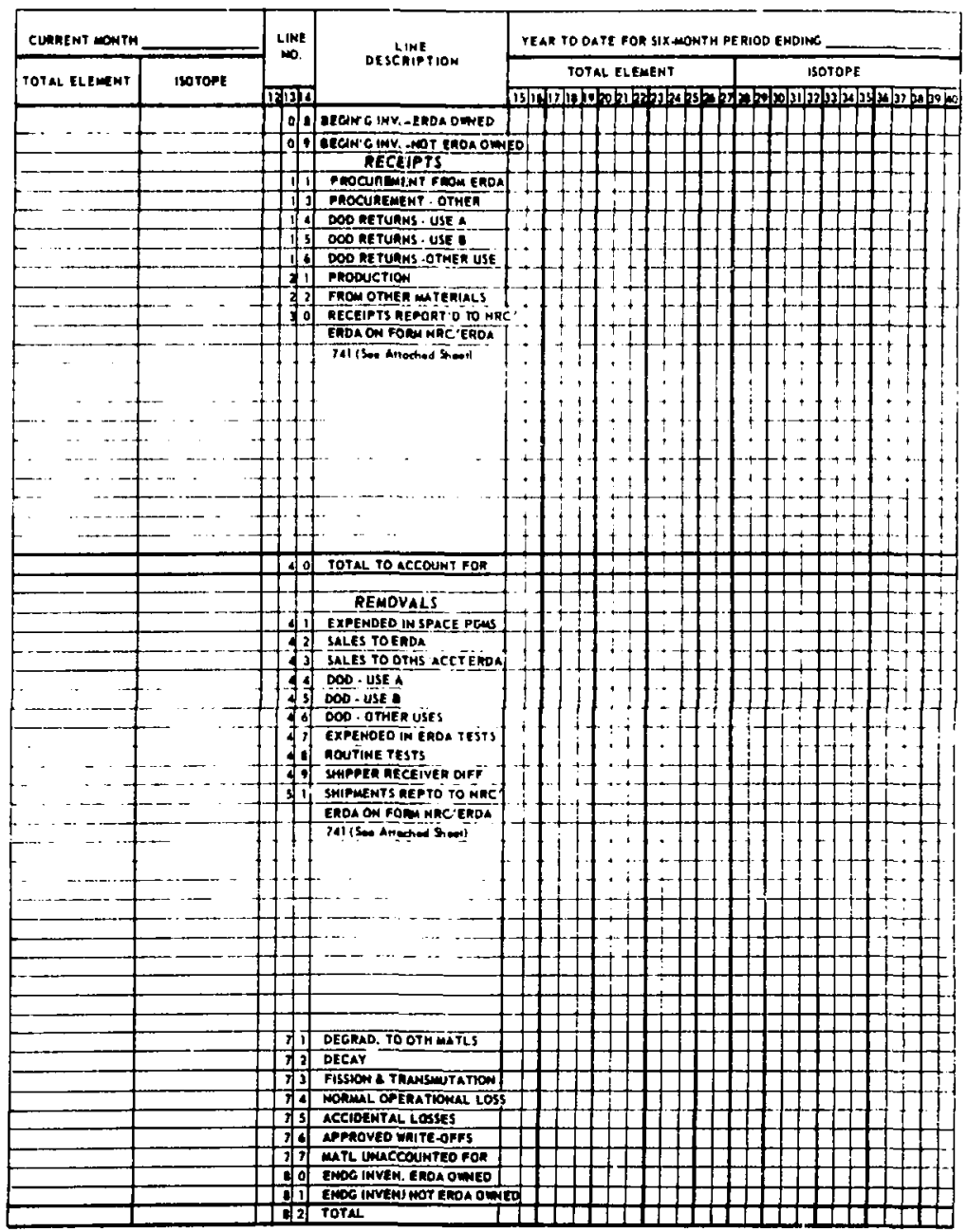


Form SA 6410 -.- Material Receiving Report

Purpose:

To record material receipts for materials which are referenced by a purchase order number.

Prepared by:

Shipping and Receiving Division.

Submitted to:

Nuclear and Explosives Materials Control Section ( 3 copies) and then forwarded to the safoguards and Technical Security Division. 
Exhibit 5.

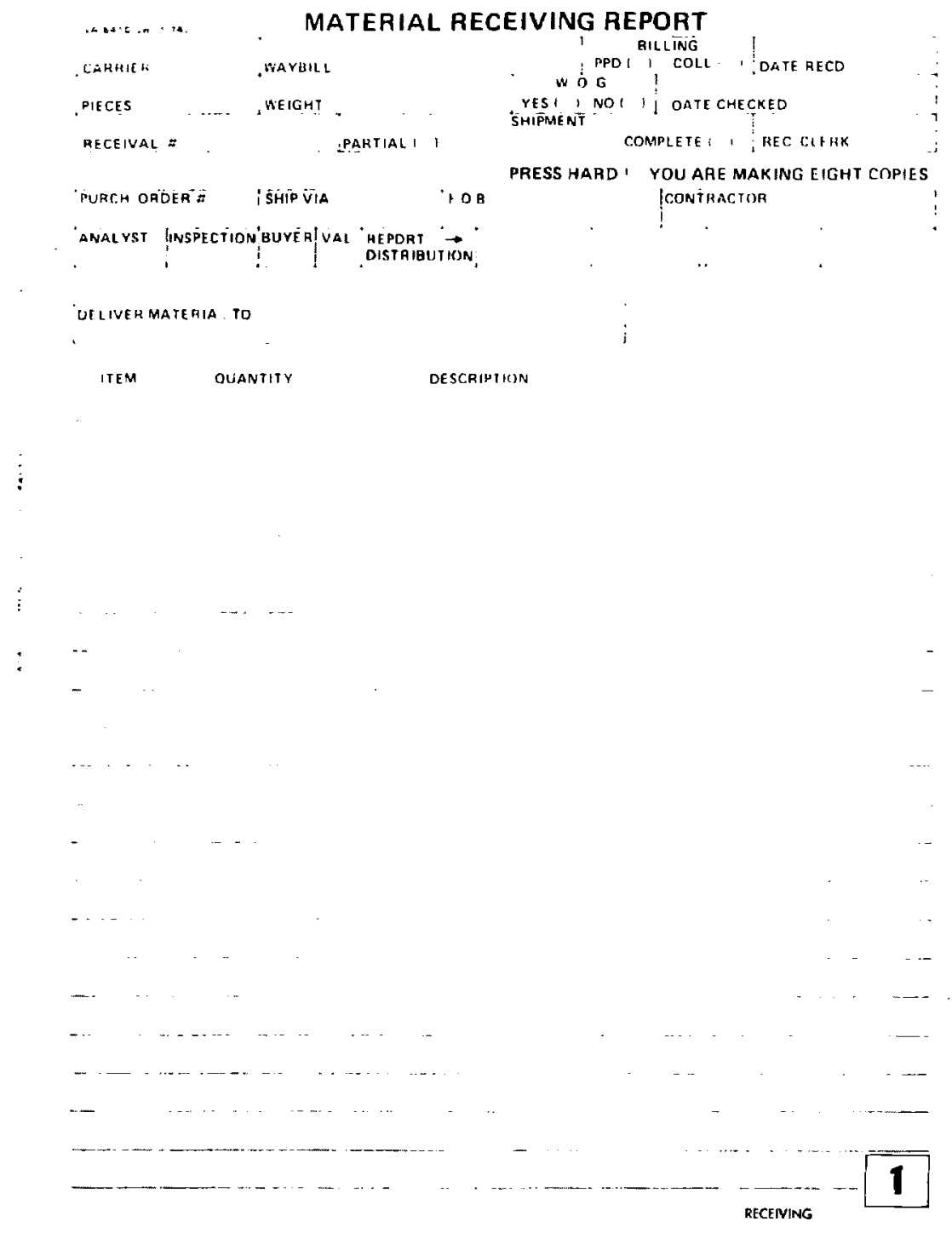




\section{Form SA blll-SC -. Material Varirref Receiving Report}

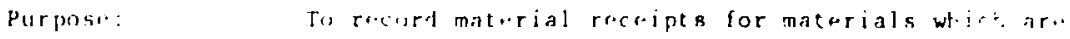
not referenced.

Preparmd li: :

Siltbmiltid 11, :
Shipping and Riviviving Divisinn.

Nu, lear and fexplasives, Mat.riale Conteol s. ti.ne (2 copites) and then forwardred to the Safotguarde and linhical Sinurity loivision. 
stit: it:

WAIIRIAL VARIREF RECEIVING REPORT
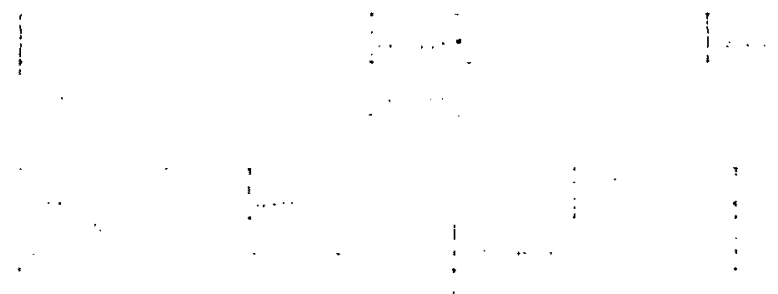

$a_{1}$

$8-15$ 
Form SA 2040-EA --- Radioactive and Nuclear Matrial- Ruceiving 51 ip

Purpose:

Priparid by:

Subrittiel to:
To supplement the receiving repor: with seriai numbers, part security classifirations, ass 4 mb) $\because$ information, and wright data.

Nucloar and Explosives Macerials Control bretion.

Safreuards and Technical Securicy Division. 
lexhibit 7.

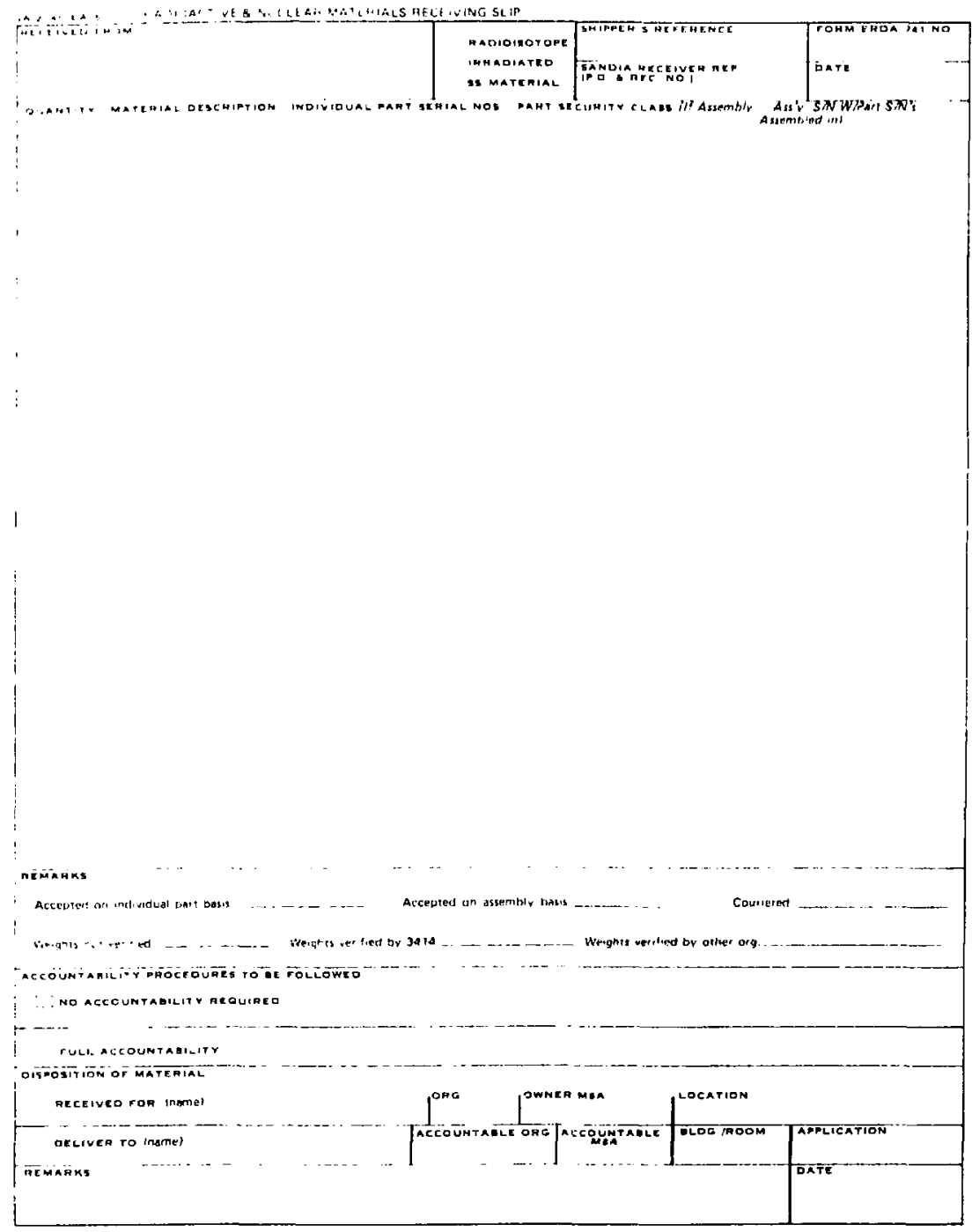




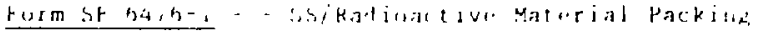

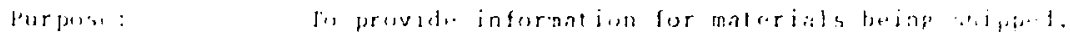

Proparel be: Nuluar and texplosivas Matorials control suetions.

Submittid by: dirizinal - carriet

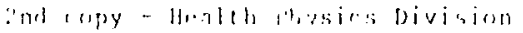

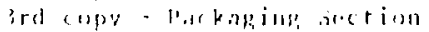

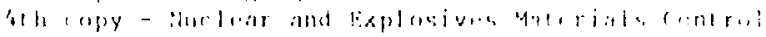

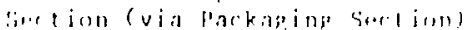

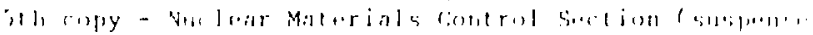
( (1,y) 


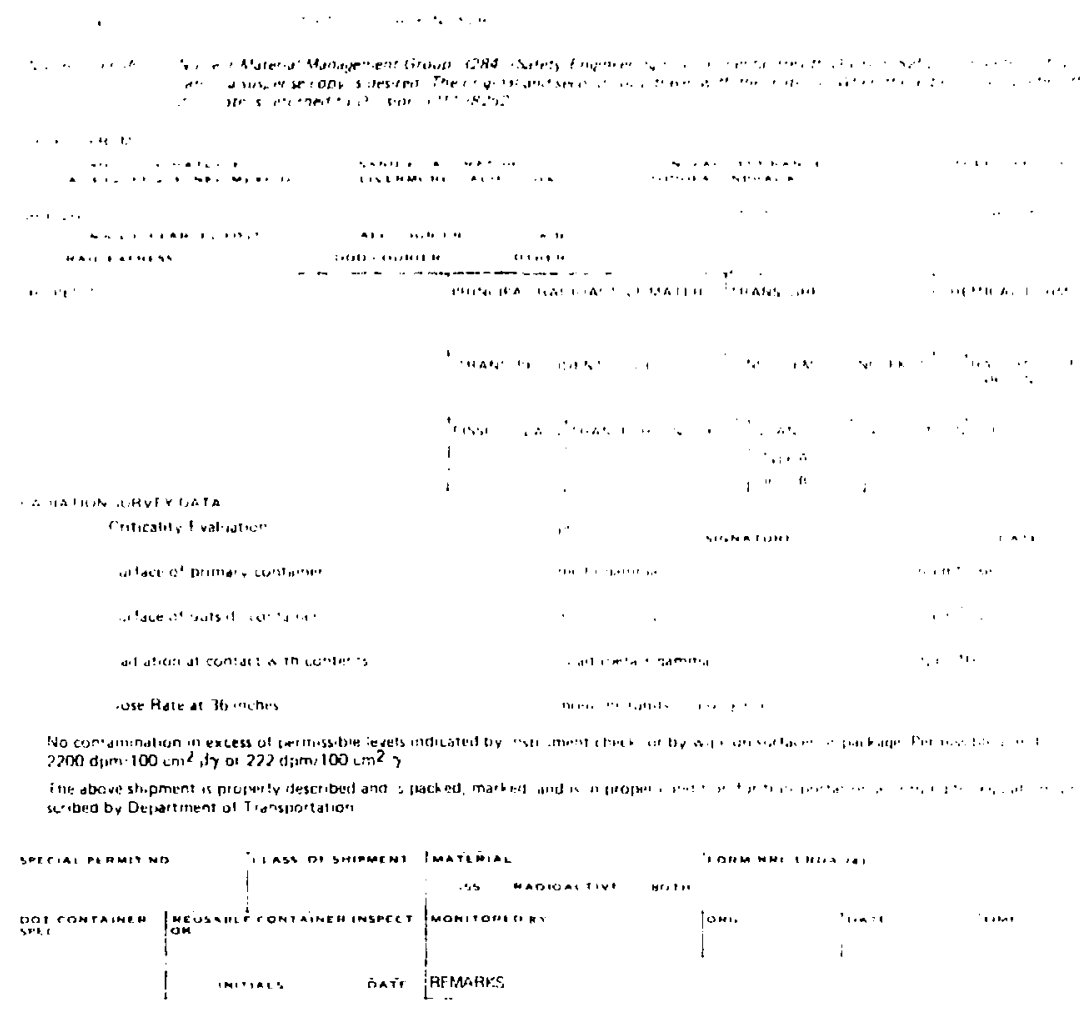

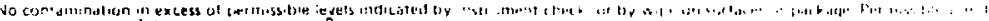

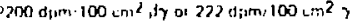

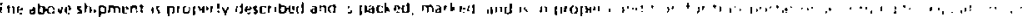

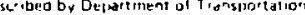




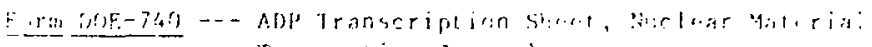

T:ansaction Journal

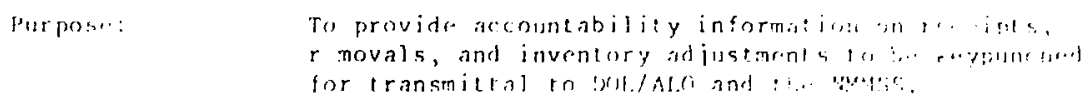

Preparer by: Safrguards and Trebmical bucurily bivisien.

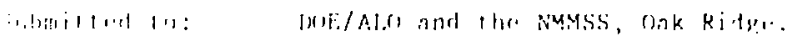




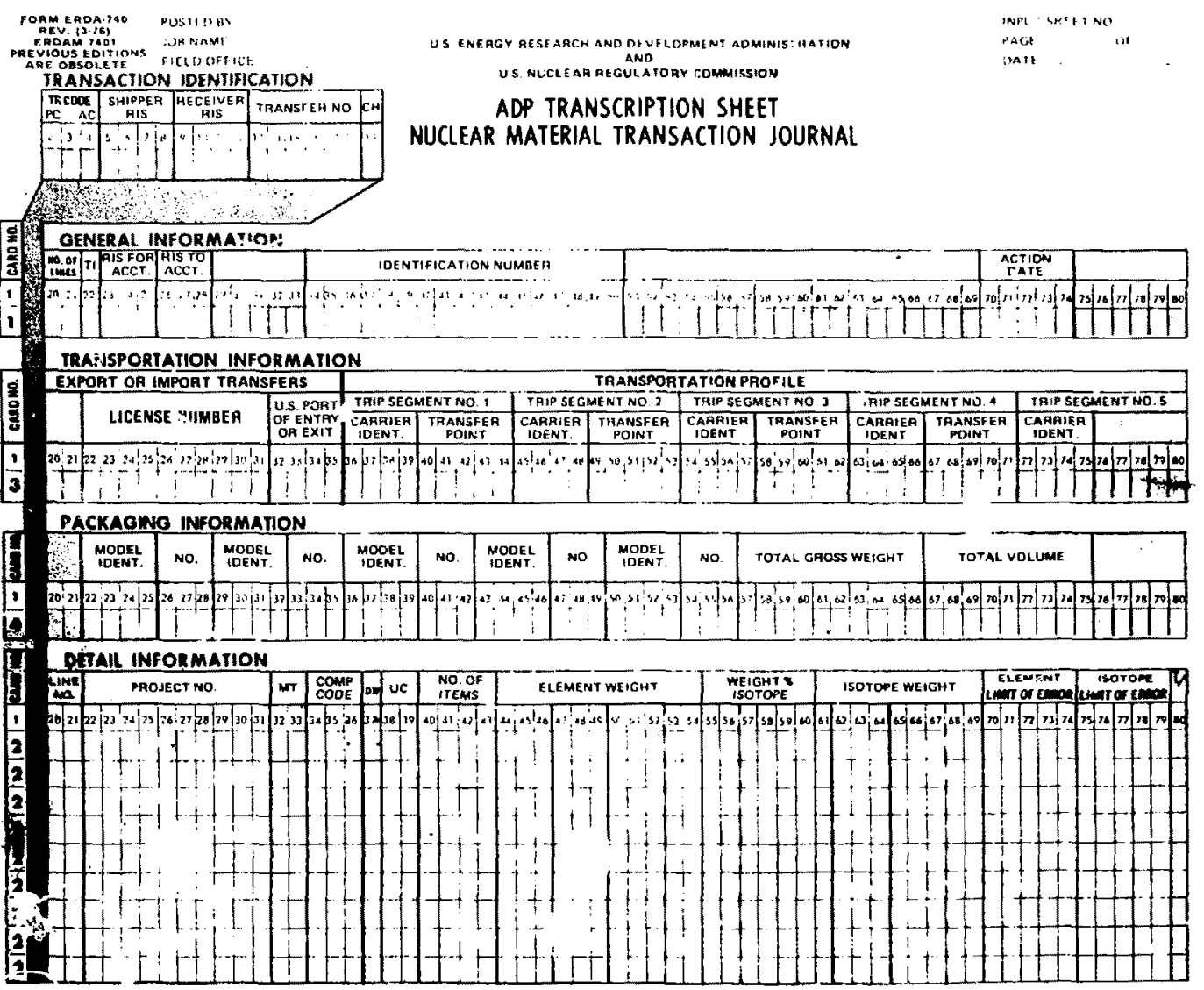


Form OR-658A --- Request for Uranium Scrap Disposit:on

Purpose:

To request disposition instructions for uranium scrap from DOE/ALO (Part 1 of the 4-part Scrap Eyaluation Report).

Prepared by:

Safeguards and Technical Security Division.

Submitted to: DOE/ALO. 
Exhibit 10.

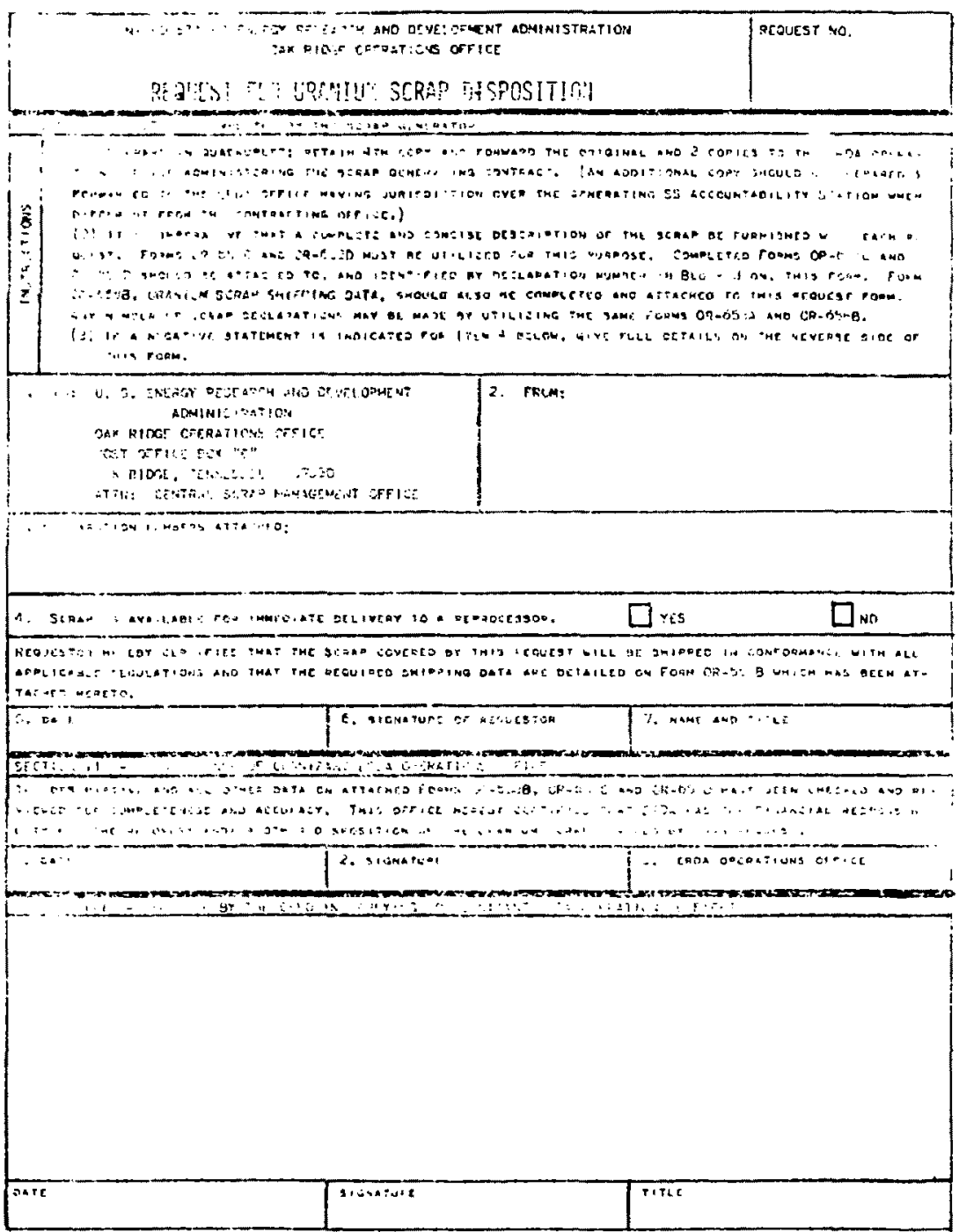

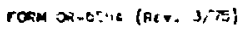


Form OR-658B --- Uranium Scrap Shipping Data

Purpose :

To provide shipping data for uranium scrap (Part 2 of 4-part Scrap Evaluation Report).

Prepared by: Safeguards and Technical Security Division.

Submitted to: DOE/ALO. 
Vixhuit 11.

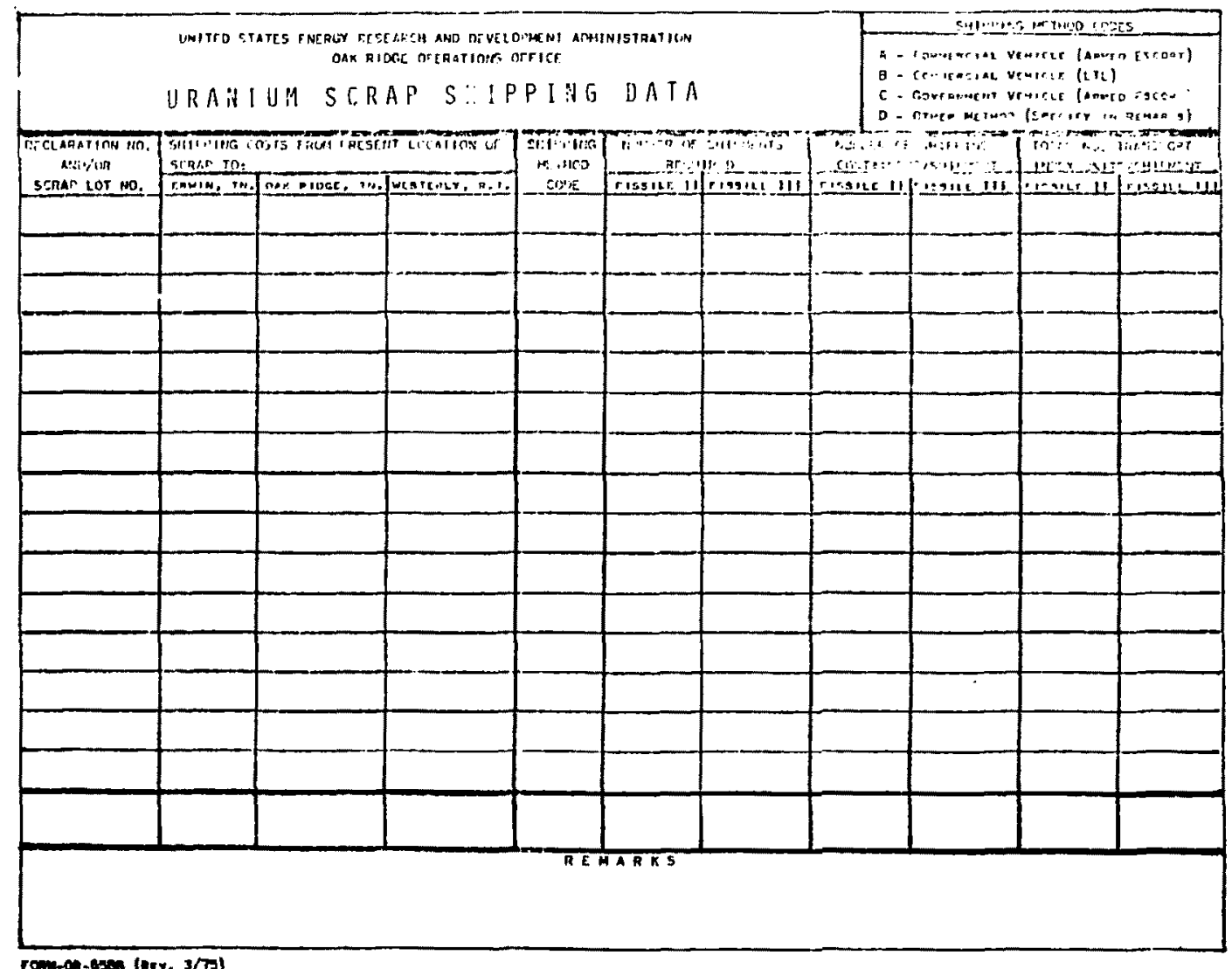




\section{Form OR-658C --- Uranium Scrap Declaration}

Purpose:

To provide packaging and weight information for uranium scrap (Part 3 of 4-part Scrap Evaluation Report).

Prepared by: Safeguards and Technical Security Division.

Submitted to: DOE/ALO. 
Vxhibit 12.

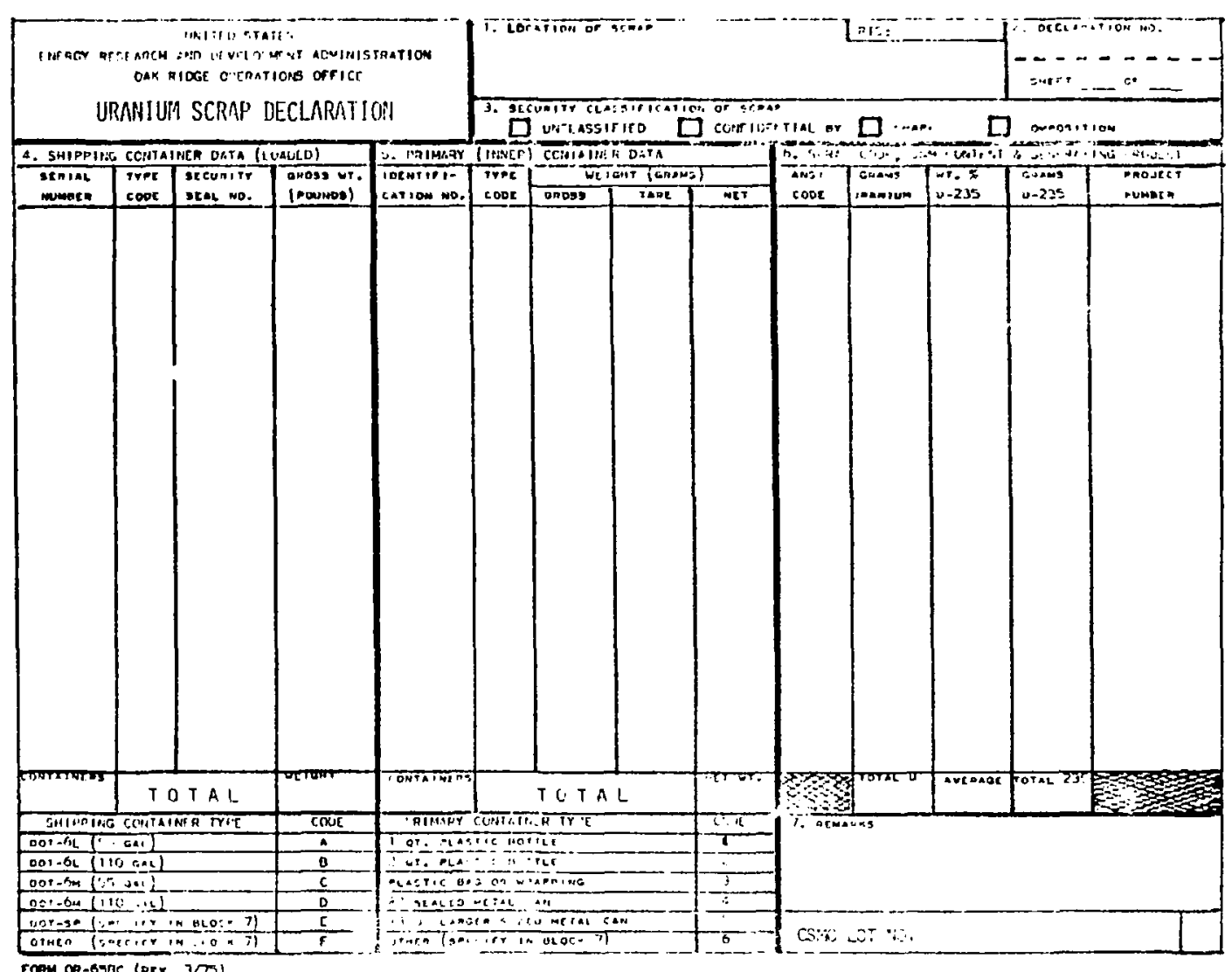




\section{Form OR-658D -- Description of Declared Uranium Scrap}

Pur pose :

To provide descriptions and shipping container numbers for uranium scrap (Part 4 of 4-part Scrap Evaluation Report).

Prepared by:

Safeguards and Technical Security Division.

Submitted to:

DOE/ALO. 
lixlibit i...

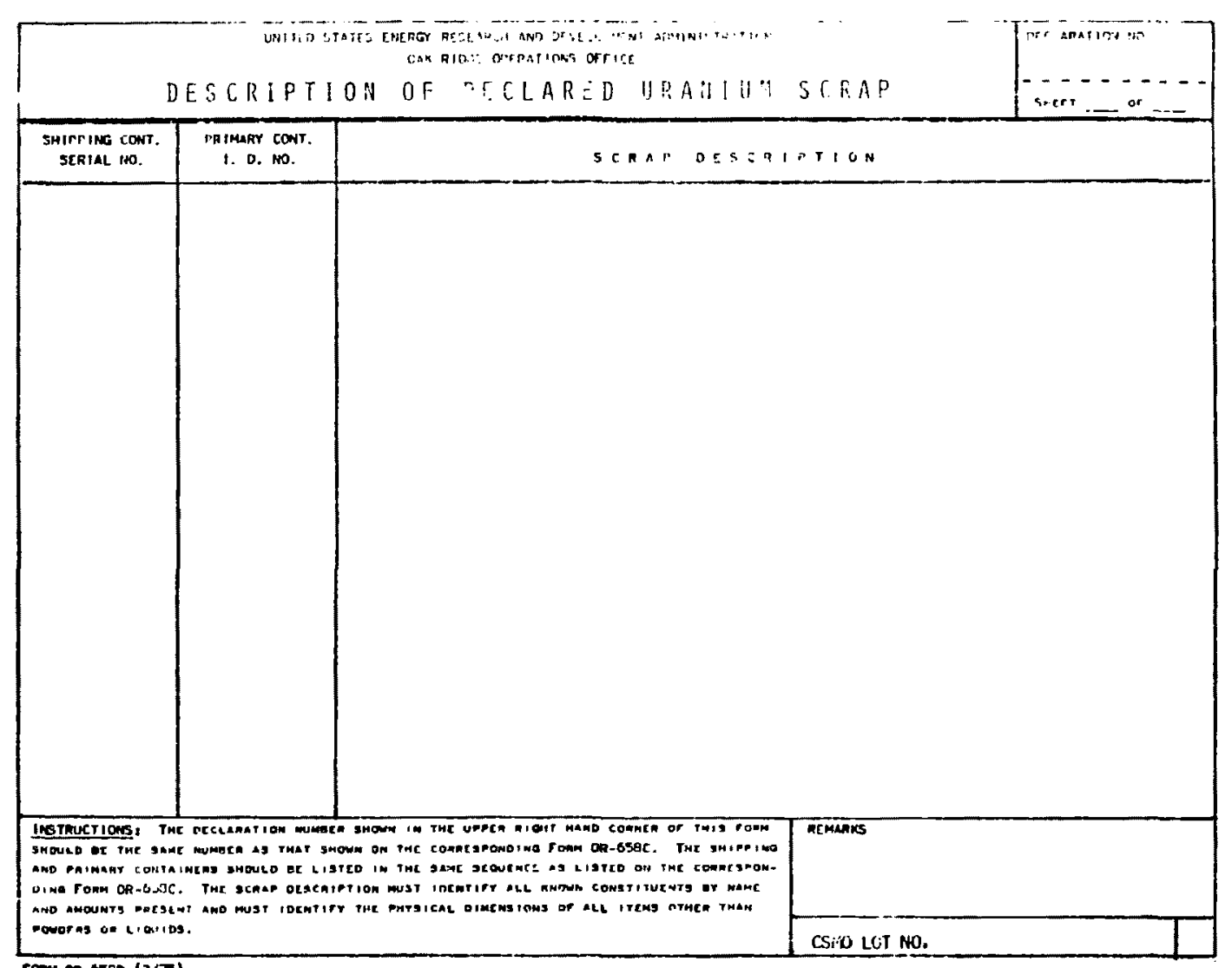


Form SC 2040-L -- Radioactive and Toxic Material Dis, pon.

Purpose: $\quad$ To record burials of nuclear materials.

Prpared by: Nuclear and Explosives Materials Control Section.

Approved by: NMR and Health Phys i Diviti. .

Submitted to: Safeguards and Technical Security Division. A copy is also recained by the Health Physics Division 
Exhibit 11 .

\section{RADIOACTIVE \& TOXIC MATERIAL DISPOSAL}

A TO BE COMPLE IFO BY RFOUESTER

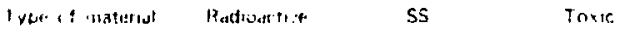

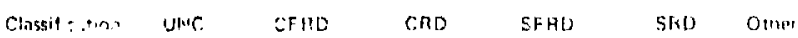

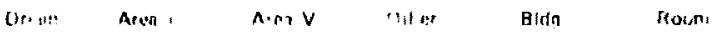

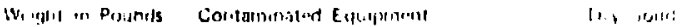

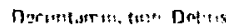

$(n+\cdots+\cdots$

Nucliefins

uhurre

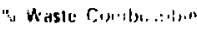

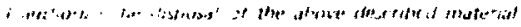

$\because$

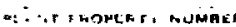

13 I6 BE CUMPLETED BY HFAI H PHYSICS DUASION

Bi.stw Cateqorirs

$$
\text { S. ' C , , k , }
$$

$\therefore$ II $\quad \therefore$ ar $k$ ।

$\therefore$ a.

11,1,

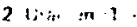

(:) R:

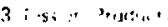

$\therefore$.

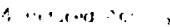

?.

a) $\cdot 9 e_{3}, \cdots$

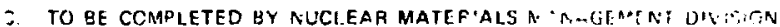

Nuclear Materials Managerment Approval

S5 Naterial Disposal Authority Heference

NMM COOR

SIGNATURE

046

DATE

D. TO BE COMPLETED BY HEALTH PHYSICS DIV'SIOI

Disposal

Buried by

Winessed by

Classified Hole Number ..

Unclassified Trench

Uranium Pat 


\section{Form DOE-741 --- Nuclear Material Transaction Report}

Purpose:

Prepared by:

Submitted to:
To record accountability transfer of nuclear materials.

Sefeguards and Technical Security Division.

Shipping and receiving suppliers, with copies to DOE/ALO and other DOE and/or military agencies (as required). 
lixhibit 15
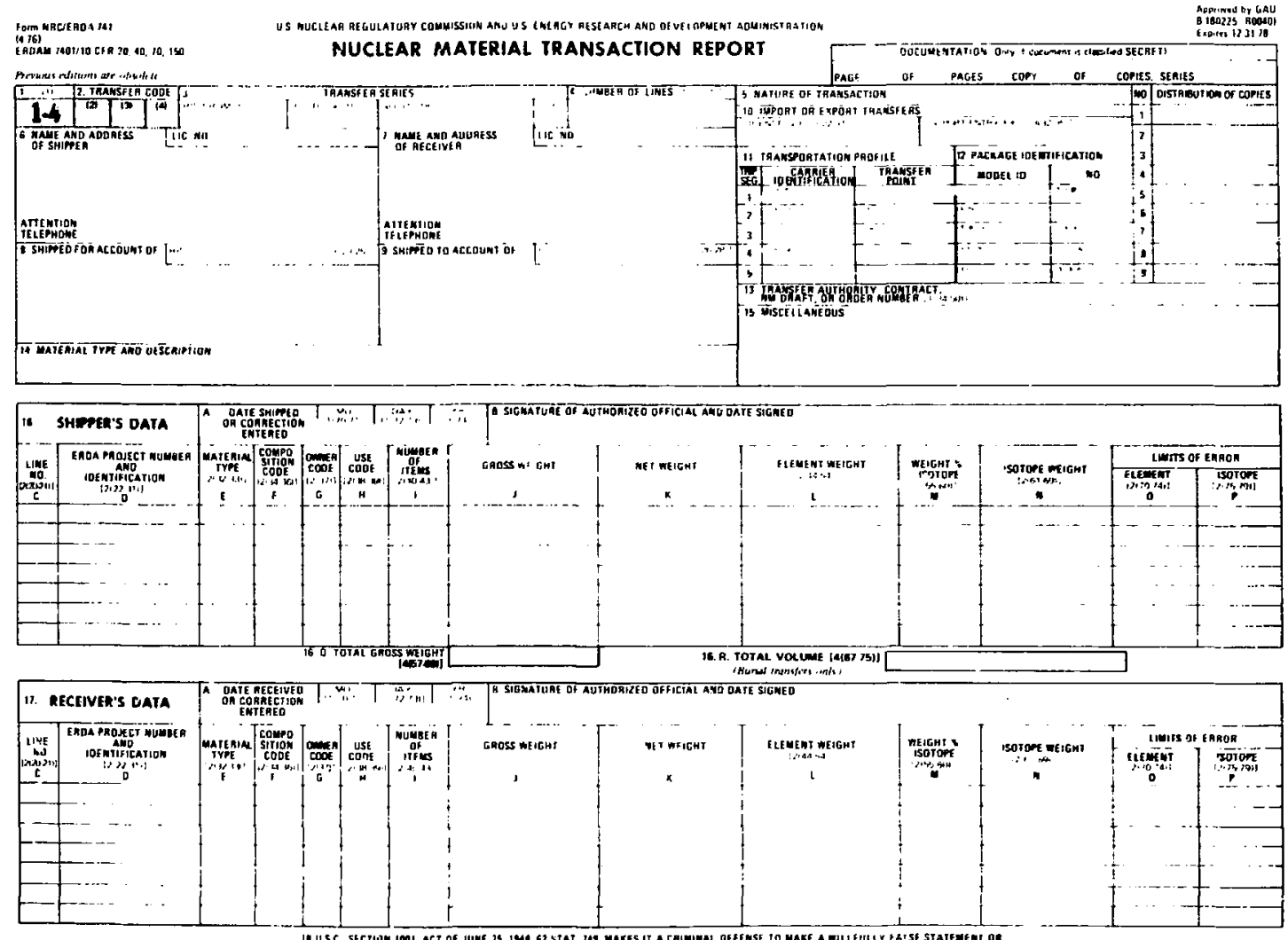

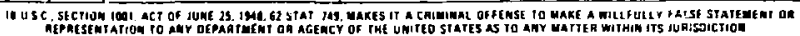




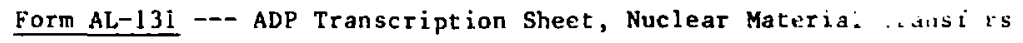

Purpose:

To record shipping and receiving data from transfer accountabjlity documents (DOE-74I), for transmission via Sacnet

Prepared by:

Safeguards and Technjoral Securitv Division

Submitted to:

Shipping and receiving suppliers having Sacnet communication system, with copies to DOE/ALO and ather DOE and/or military agencies (as required). 


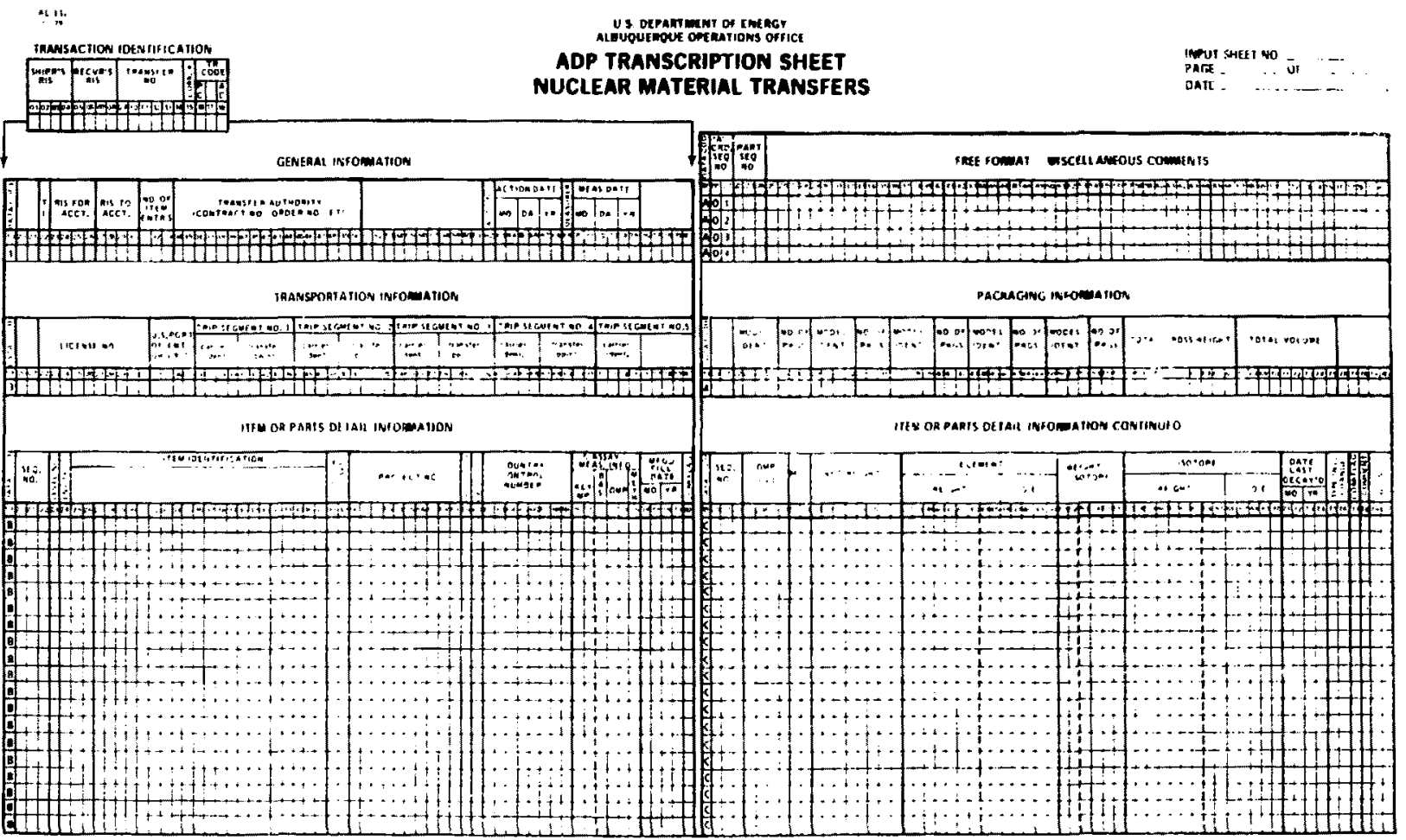


Form SR-95 --- $238 \mathrm{Pu}$ Scrap Declaration

Purpose: To provide material, cost, and shipping container data for ${ }^{238} \mathrm{Pu}$ scrap.

Propared by: $\quad$ Safeguards and Technical Security Division.

Submitted to: DOE/ALO 


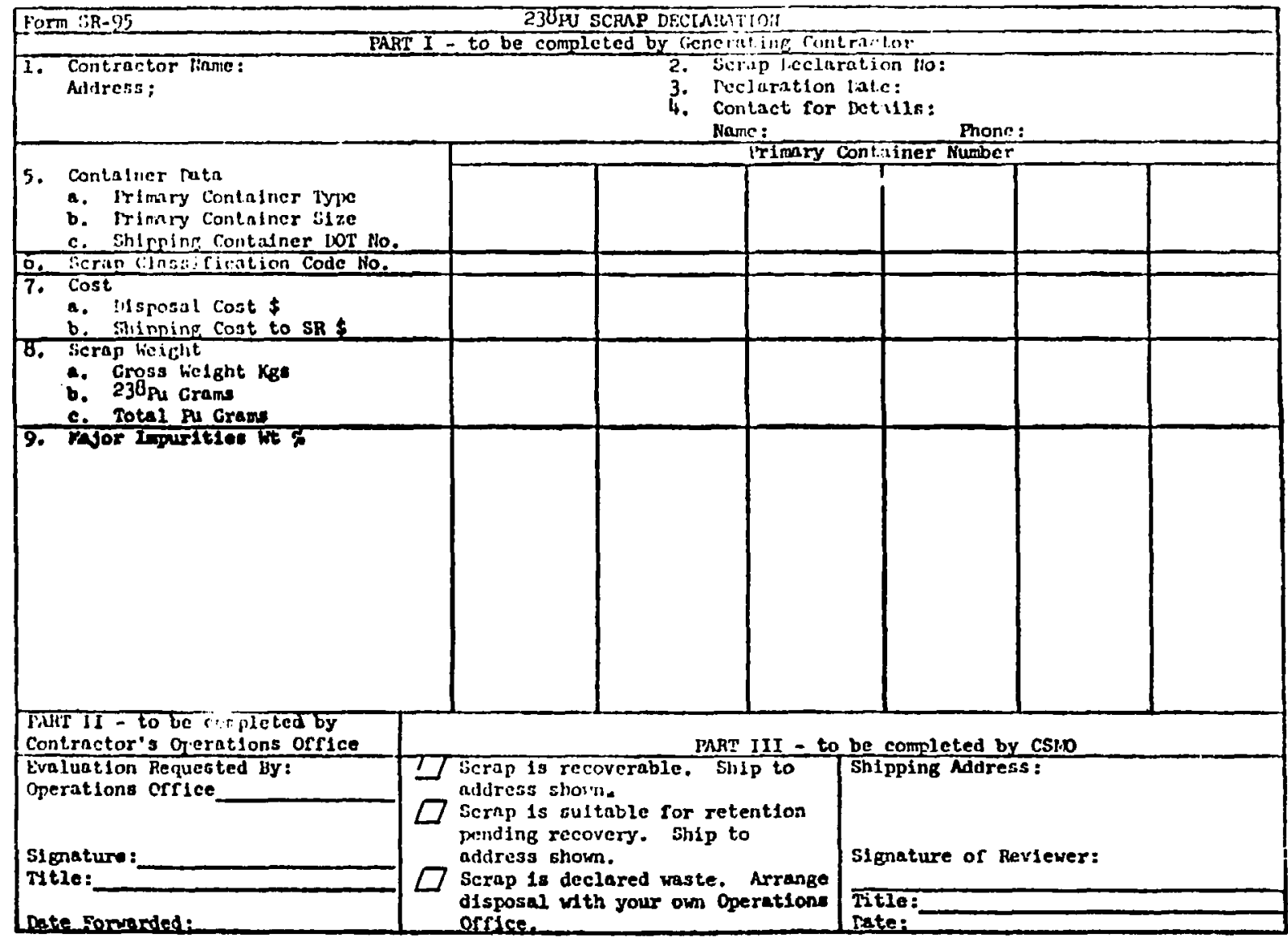




\title{
Form SA 6476-NF --- Inventory Adjustment Form
}

\author{
Purpose: \\ To record weight adjustments of nuclear materials \\ Prepared by: \\ Safeguards and Technical Security Division. \\ Approved by: \\ Nuclear materials maiger ar nu:lear materials \\ representative \\ Submitted to: Retained in the inventory adjustment file.
}


lixitut I"

INVENTORY AD JUSTMENT FORM

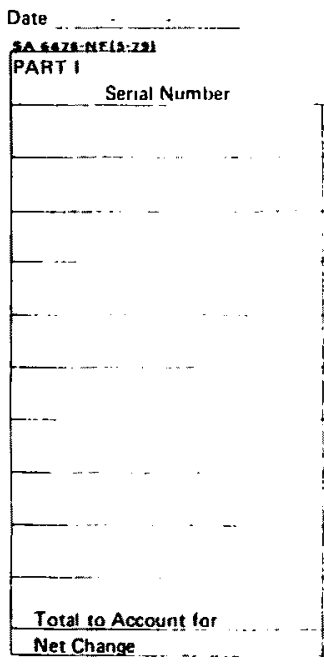

MT

Unit ...

Net Weight Incteas: IDebat Eie, Nerghi

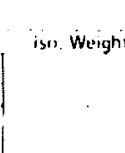

Remarks:

'TART II

Approved by

Date

Comments:

PART III

COMFUTER INPUT

Date

Inituals

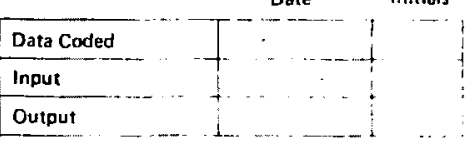

NMMS

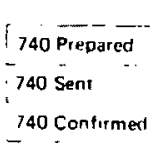

Proper No

№

0142

IAF No.

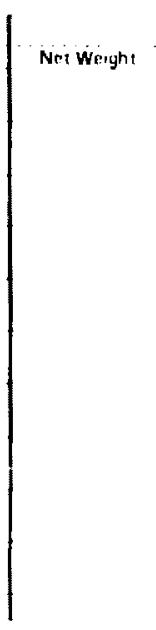

Dectease (Credil)

Ele Werght
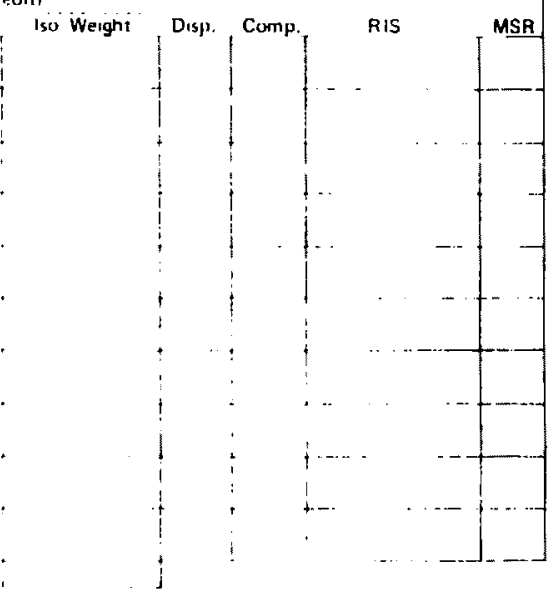

Memo to ALO

'No

Date ... -

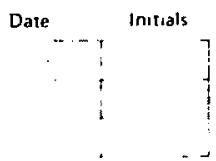

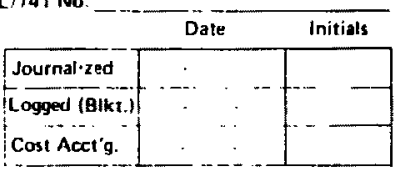


From SA 2042-DA -- Nuclear Materials Machining Report

Purpose: $\begin{aligned} & \text { To record inventory adjustment source data resulting } \\ & \text { from machining. }\end{aligned}$
Prepared by: $\quad$ Safeguards and Technical Security Division.
Submitced to: $\quad$ Retained in the inventory adjustment form (IAF) filp. 
Ex:ibit 19

NUCLEAR MATERIALS MACHINING REPORT

SENO TO. SAFEGUARDS AND TECHNICAL SECURITY DIVISION - 3434

FROM MBA CUSTODIAN _...

CASE NUMBER.

SERIAL NUMBER MODIFIED

NET WEIGHT

DESCRIPTOR

IUSE OLO DESCRIPTOR WITH SUFFIXI

NEW SERIAL NO.

NET WEIGHT

-..

-.

$-$

$-$

$-$

$-$

$+\ldots$
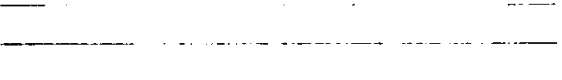

- TOTAL

REMARKS:

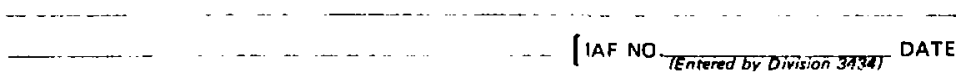

- NOTE: Total weight ol new iterns (including scrap) must balance with weight of original serial number. Indicate when item is scrap 
AnP Transcription Sheet, Sealed Source Registration Data

Purpose: $\quad$ To provide information on receipts of sealed sources on magnetic tape for transmittal to DOE/ALO and to the NMMSS.

Prepared by: Safeguards and Technical Security Division.

Submitted to: Keypunch and Communications Section. 
POSTKD BY

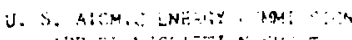

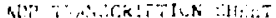

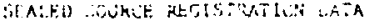

DAIE

PAGE
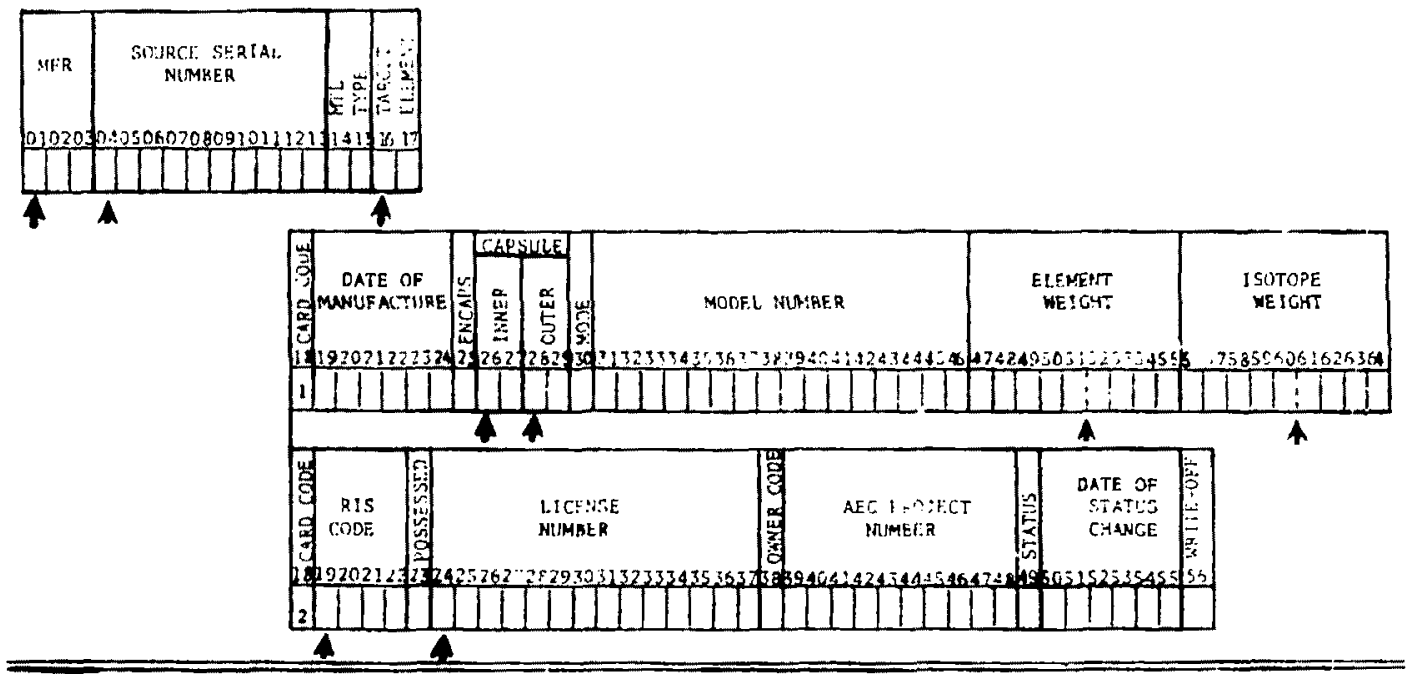

THALD SCLATE INTLTERITY DATA

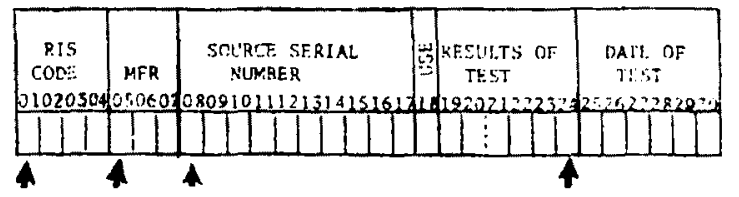


Form DOE-749 -- ADP Transcription Sheet. Internal Project Tratisfers

Put pose :

To provide information on internal project transfurs (project number changes) on magnetic tape for transmittal to DOF./ALO and to the MMYSS.

Prpared by:

Safrguards and Technical Security Divisinn.

Submitled to: Krypunch and Communications Sretun. 


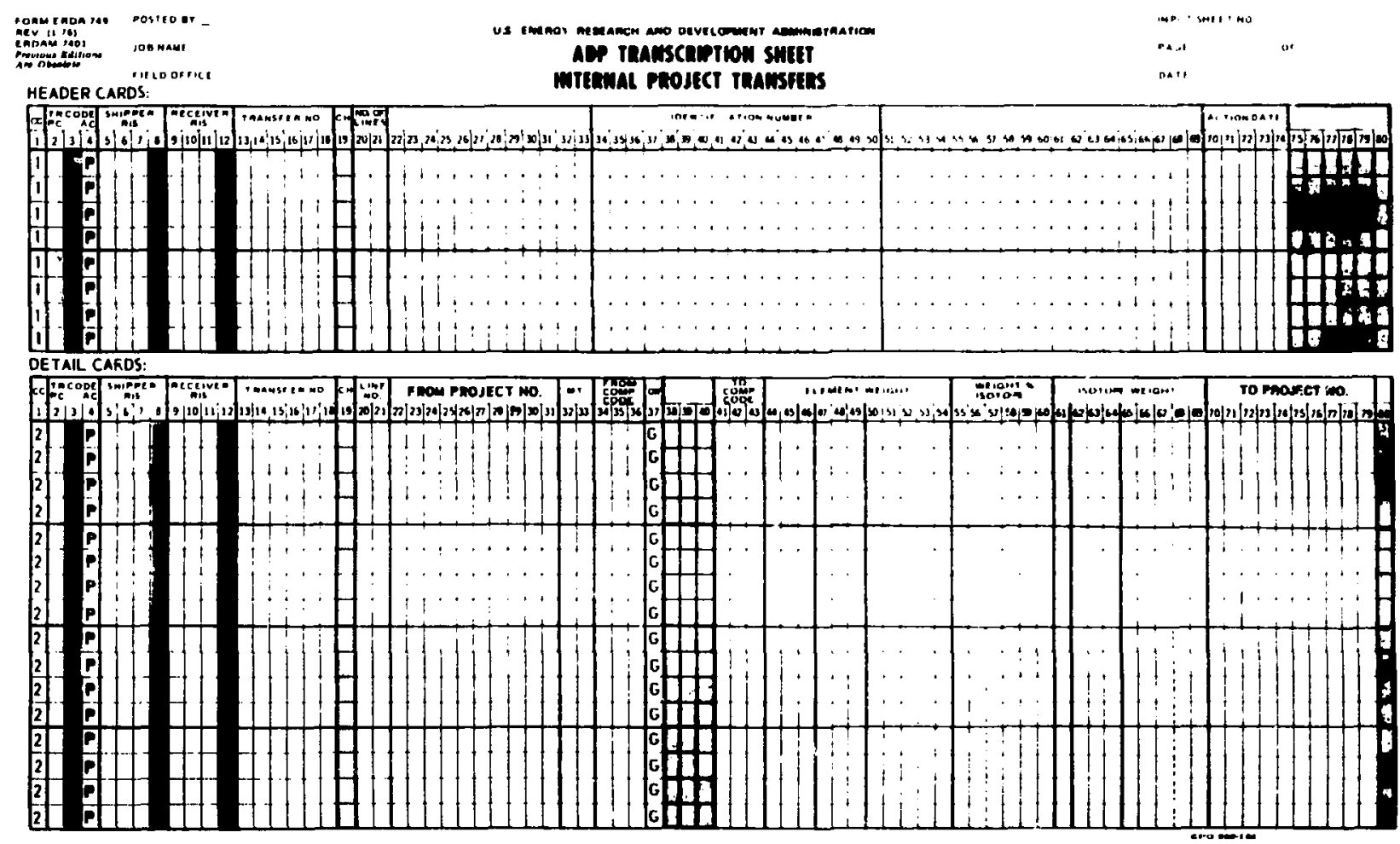


Form SF 1811-ABA -- Telecommunication Data Message Form

Purpose:

Prepared by:

Submiterd to:
To provide information for the transmitcal of data to DOE/ALO, the NMMSS, and other contractors (as required).

Safeguards and Technical Security Division.

Keypunch and Communications Section. 


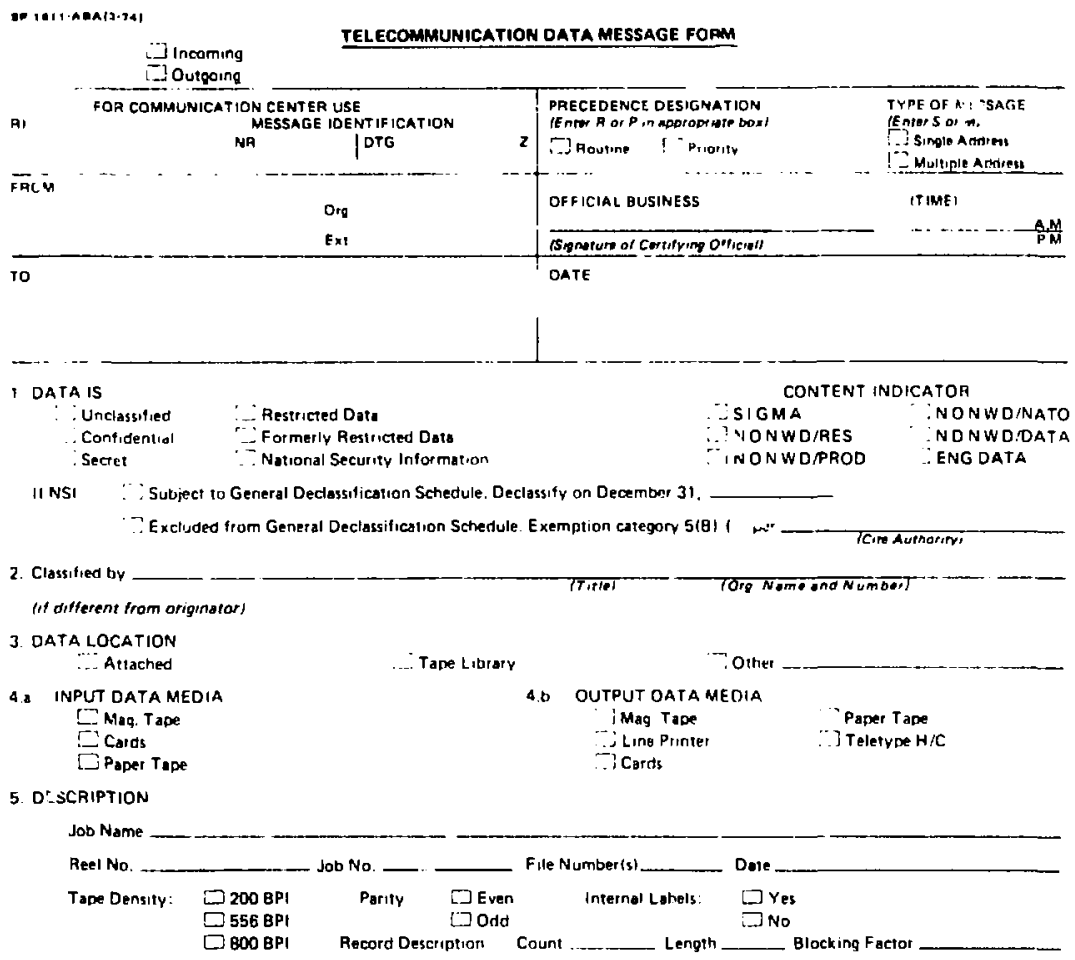

6. SPECIAL HANDLING INSTRUCTIONS

7. DELIVER THIS FDRM TO

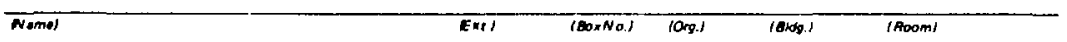




\begin{abstract}
Purpose: $\quad$ To inform shippers of a delay in completing the transfer accountability document (DOE-741) for material receipts.

Prepared by:

Safeguards and Technical Security Division.

Submitted to:

Shipping supplier and applicable field offices.
\end{abstract}


lixhibit 23

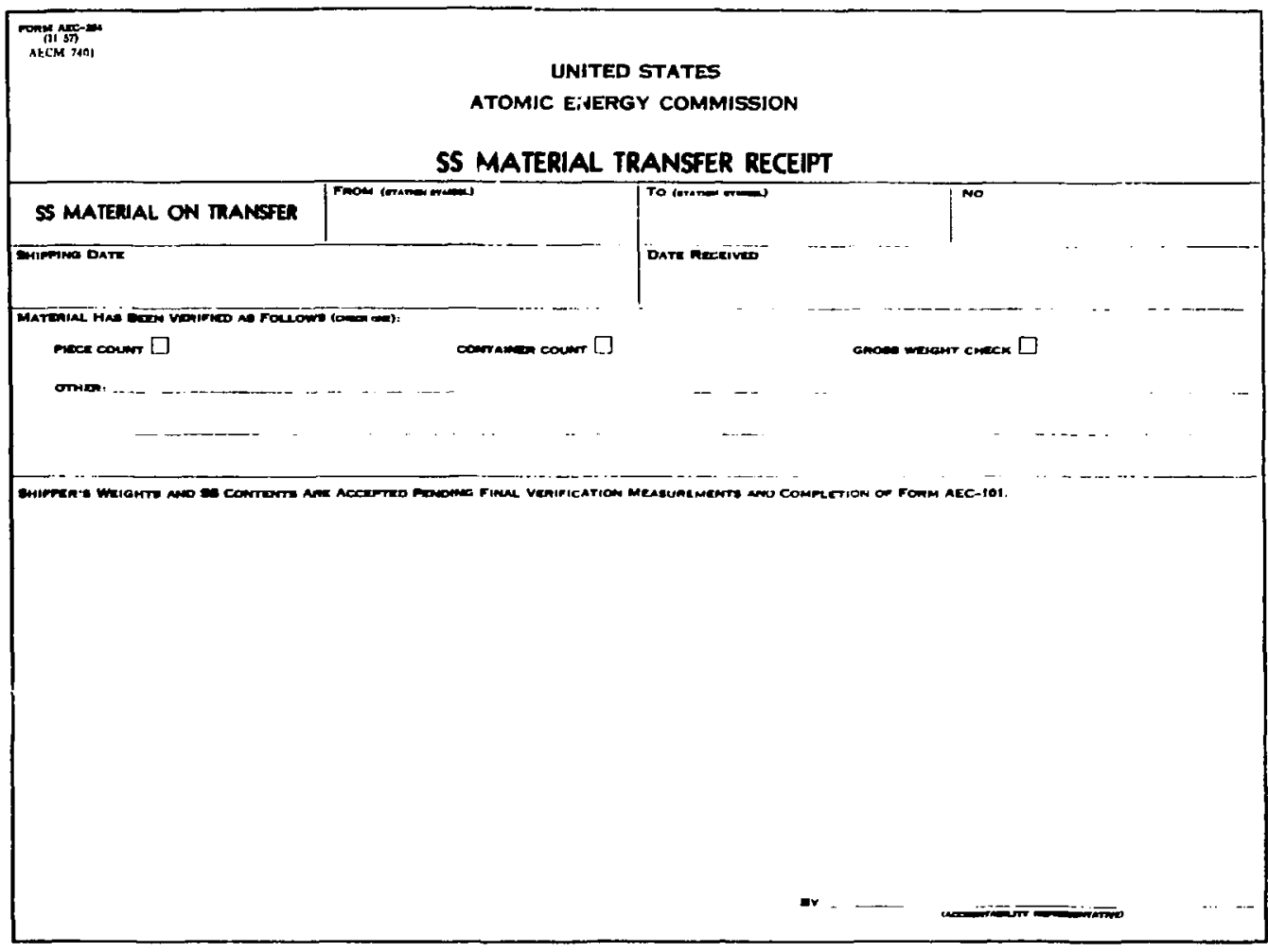

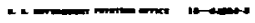

c00 $\infty 111$ 
Form SA 2900-J --- Receipt for Classified Information
Purpose:
To verify the receipt of classified documents.
Prepared by:
Safeguards and Technical Security Division.
Submitted to:
Accompanies the classified document.

$8-50$ 


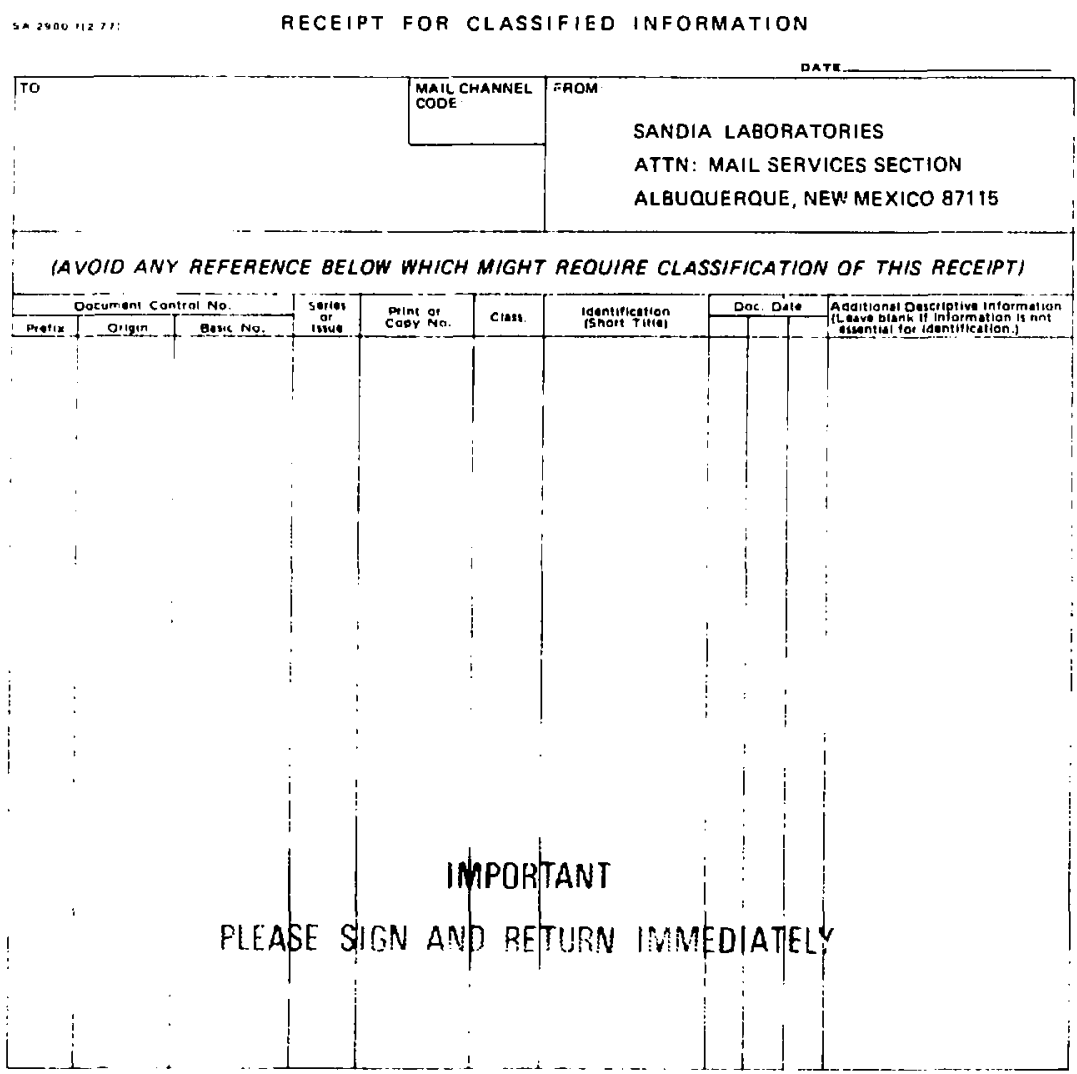

NOTE FOR SANDIA CONSULTANTS AND SUPPLIEFS if inis recept iranimits Weapon Data of Research and Development Reports. protect in secordance wish EADA Manumi Chipter 2105 or 2100.

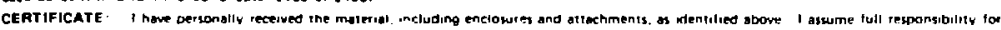

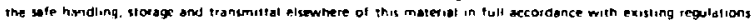

TOST - DLEASSIFICATION CODES

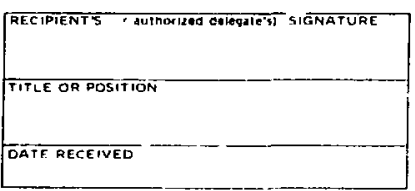

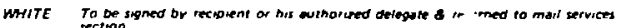

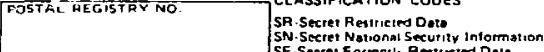

SF. Seeret Formptl, Pesticred Ds

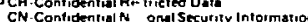

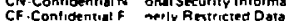

YELLOW. For rerident; tite.

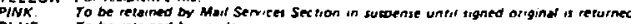

BLUE TO be retained or sender.

RECEIPTEO WHITE COPY MUST BE RETUANE TO SANOIA LABORATORIES MAIL SERVICES SECTION 
Form SA 2042-D --- Nuclear and Radioactive Material Transfer

Purpose: $\quad$ Accountability transfer between $\mathrm{MBA}^{\prime} \mathrm{s}$

Prepared by: Custodian/Alternate Custodian

Submitted to: White Copy - Receiving Custodian Yellow Copy - Nuclear Materials Control Section Green Copy - Safeguards and Technical Security Division Pink Copy - Safeguards and Technical Security Division Goldenrod Copy - Sending Custodians 
lixhibit 25

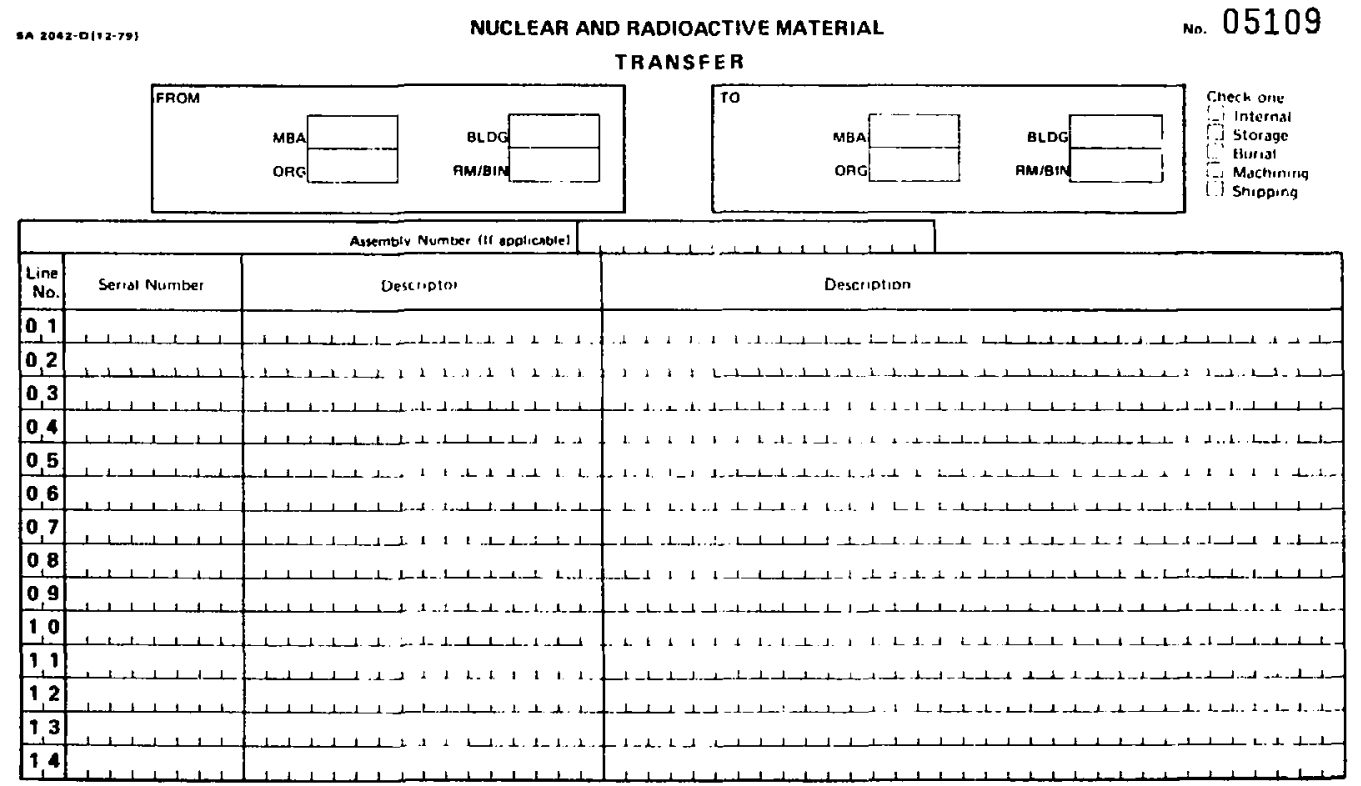

Remarks:

Transfered from _tocepled by Movatume

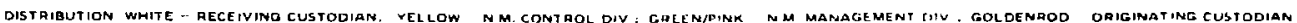




\section{Form SA 6476-NF --- Inventory Adjustment Form}

Purpose: To record the data required for adjusting inventory master records and provide backup for audit purposes

Prepared by: Safeguards and Technjcal Secirity Division

Submitted to: Retained in the inventory adjustment form (IAF) file. 
lixhitil 26

\section{INVENTORY ADJUSTMENT FORM}
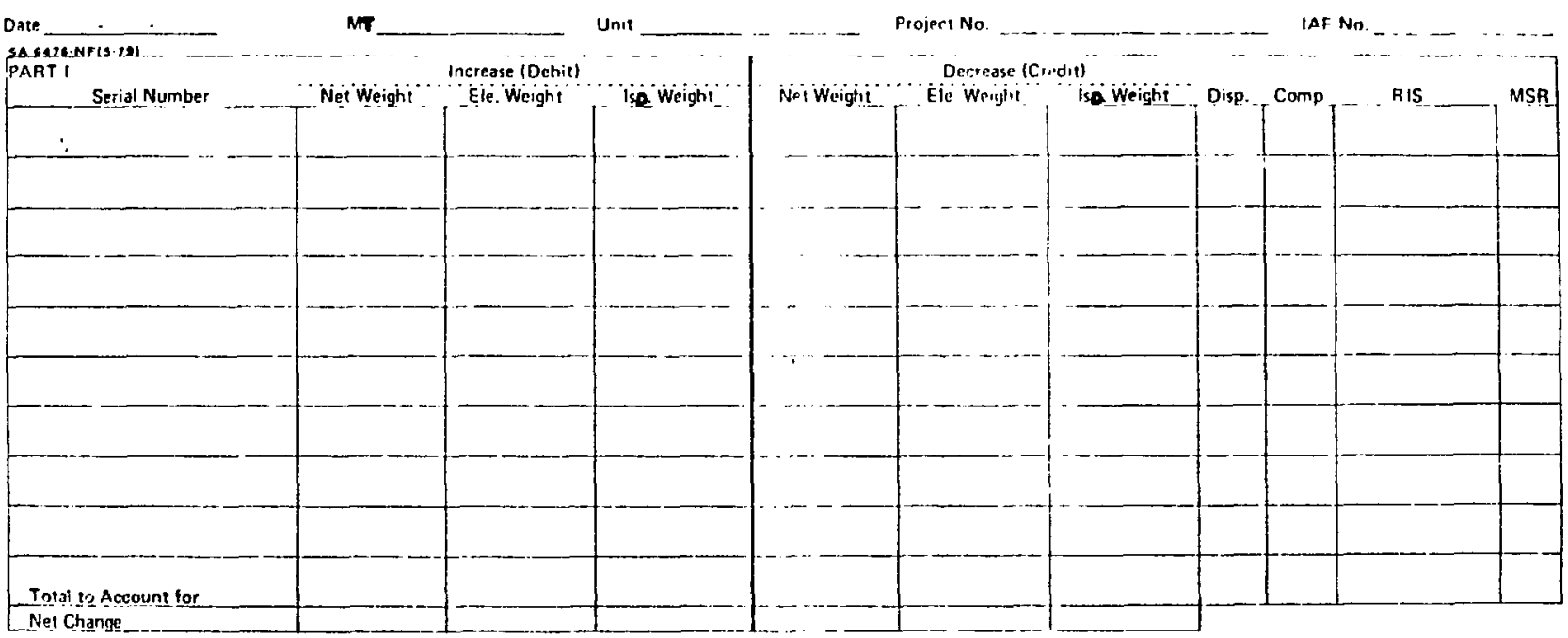

Romarks:

\section{PART II}

Approved by

Date

Menio to ALO $\square$ Yes П.No

Date

Comments:

\section{PARTT III}

COMPUTER INPUT

$\infty$
$u$
$u n$
un
NMMS

\begin{tabular}{|c|c|c|}
\hline & Date & Initials \\
\hline 740 Prepared & - & \\
\hline 740 Sent & $\cdot$ & \\
\hline 740 Confirmed & - & \\
\hline
\end{tabular}

BURIAL/741 No.

\begin{tabular}{|c|c|c|}
\hline & Dais & Initials \\
\hline Journalized & . & \\
\hline Logged (Blkt.) & - & \\
\hline Cost Acet'g. & - $\quad-$ & \\
\hline
\end{tabular}


'ISFRS' MANUAL.

The informat in conlainced in this chapter and the succeeding chapter (Chapler $X$ ) has hen compiled from the previous chapters to provide a concisp and comprelionsive summary of opreating procedures for custodians and users of radioactive anit nuclear materials. These chapters contain only the information and procedures relcuant to custodians and users of radioactive and nuclcar matrials, and tl $\because$ two chaplers are combined and issued separately as a creument entitled "Operating procedures for Custodians and "sers of Nuclear Materials" which is distributed to all custodians, altcruate custoiians, and using organizations. Chapter IX forms the body of that document exactly as it appears in the separate issue, and Chapter $X$, "Compenditm of Relevant Nuclear Materials User Forms," contains the forms which are included in the appendix of that document. Both chaptris arr included in this manual for the sake of completeness. 
OPERATING PROCEDURES FOR CUSTODIANS AND USERS

OF RADIOATIVE AND NUCLEAR MATERIALS

\section{]. Definitions}

Accountabie materials -- a collective term which includes accumulations of nuclear materials above specified quantities (after rounding) and reportable in specified units as follows:

\begin{tabular}{|c|c|c|c|c|}
\hline \multicolumn{2}{|r|}{ Nuclear Material } & \multirow{2}{*}{$\begin{array}{l}\text { Reporting l'nit } \\
\text { kilogram }(\mathrm{kg})\end{array}$} & \multirow{2}{*}{$\begin{array}{c}\begin{array}{c}\text { Reportable } \\
\text { Qty. }\end{array} \\
>500 \mathrm{~g}\end{array}$} & $\begin{array}{c}\text { Negligible } \\
\text { Qty. }\end{array}$ \\
\hline$M T-10$ & $\begin{array}{c}\text { - Depleted Uranium } \\
\text { (1238) }\end{array}$ & & & $<500 g$ \\
\hline$M T-20$ & $\begin{array}{c}\text { - Enriched Uranium } \\
\text { (U235) }\end{array}$ & Gram $(g)$ & $>0.5$ & $<0.5$ \\
\hline $\mathrm{MT}-40$ & - Plutonium 342 & Gram & $>0.5$ & $<0.5$ \\
\hline$M T-44$ & - Americium 2łl & Gram & $>0.5$ & $<0.5$ \\
\hline$M T-45$ & - Americium 243 & r.ram & $>0.5$ & $<0,5$ \\
\hline $\mathrm{MT}-46$ & - Curium & Gran & $>0.5$ & $<0.5$ \\
\hline $\mathrm{MT}-47$ & - Berkelium 249 & Microglam (mg) & $>0.5 \mathrm{mg}$ & $<0.5 \mathrm{mg}$ \\
\hline$M T-48$ & - Californium 252 & Microgram & $>0.5 \mathrm{mg}$ & $<0.5 \mathrm{mg}$ \\
\hline $\mathrm{MT}-50$ & - Plutonium 239 & Gram & $>0.5 \mathrm{~g}$ & $<0.5 \mathrm{~g}$ \\
\hline $\mathrm{M} T-60$ & $\begin{array}{l}\text { - Lithium Enriched } \\
\text { in Li } 6\end{array}$ & Kilogram & $>500 \quad 8$ & $<500 \mathrm{~g}$ \\
\hline $\mathrm{MT}-70$ & - Uranium (U233) & Gram & $>0.5 \mathrm{~g}$ & $<0.5$ \\
\hline $\mathrm{MT}-81$ & - Heptunium 237 & Kilogram & $>500 \mathrm{~g}$ & $<500 \mathrm{~g}$ \\
\hline MT-82 & - Neptunium 237 & Sir am & $>0.5 \mathrm{~g}$ & $<0.5 \mathrm{~g}$ \\
\hline $\mathrm{MT}-83$ & - Plutonium & Gram to Tenths & $>0.05 \mathrm{~g}$ & $<0.05 \mathrm{~g}$ \\
\hline YT -86 & - Deuterium & Kilogram to Tenths & $>0.10 \mathrm{~kg}$ & $<0.10 \mathrm{~kg}$ \\
\hline $\mathrm{MT}-87$ & - Tritium & Gram to Hundredths & $>0.005 \mathrm{~g}$ & $<0.005 \mathrm{~g}$ \\
\hline $\mathrm{MT}-88$ & - Thorium & kilogram & $>500 \mathrm{~g}$ & $<500 \mathrm{~g}$ \\
\hline
\end{tabular}

Category I quantities of special nuclear materials -- Plutonium $2 \mathrm{~kg}$ or more; $233 \mathrm{U}-2 \mathrm{~kg}$ or more; $235 \mathrm{U}$ (contained in uranium enriched to $20 \%$ or more) $-5 \mathrm{~kg}$ or more. If pluconium or $233_{\mathrm{U}}$ is combined with $235 \mathrm{U}$, the amounts of Pu or 233 u shall be multiplied by 2.5 to arrive at the limits shown.

Category II quantities of special nuclear materials -- Plutonium 400 to $1999 \mathrm{~g} ;{ }^{233} \mathrm{U}-400$ to $1999 \mathrm{~g} ;{ }^{235} \mathrm{ll}$ (contained in uranium enriched 
to $20 \%$ or more) -1000 to $4999 \mathrm{~g}$. If plutonium or $233 \mathrm{U}$ is combined with ${ }^{235} \mathrm{U}$, the amounts of $\mathrm{Pu}$ or ${ }^{233_{\mathrm{U}}}$ shall be multiplir.d by 2.5 to arrive at the limits shown.

Category III-A quantities of special nuclear materials -- Plutoniım 220 to $399 \mathrm{~g} ;{ }^{233} \mathrm{U}-220$ to $339 \mathrm{~g} ;{ }^{235} \mathrm{U}$ (contained in uranium enriched to $20 \%$ or more) -350 to 999 g. A plutonium and/or 233 u content of less than 400 g may be combined with ${ }^{235} \mathrm{U}$ when the total content is less than $1000 \mathrm{~g}$.

Category III-B quantities of special nuclear tnaterials -- plutonium 1 to $219 \mathrm{~g} ;{ }^{233} \mathrm{U}-1$ to $219 \mathrm{~g} ;{ }^{235} \mathrm{U}$ (contained in uranium enriched to $20 \%$ or more) - 1 to 349 a: $235_{3}$ (contained in uranium unriched to loss than $20 \%$ - all quantitirs above $0.99 \mathrm{~g}$.

Cont inuous surveillance -- the observation of Catroorv $I$ and II special nuclear materials or their container when in usfor in open storage by at least two authorized, 0-cleared persons who may be doing other work but who can given an alarm in time to prevent the unauthorized removal of the special nuclear materials.

Custodian/alternate custodian -- thr persons designated by using organizations (and approved by their Director) to control and account for all nuclear materials within a material balance arra.

Excess materials -- nuclear materials for which there is no planned and approved programmatic use during the near term.

Fissile materials -- a collective term which includes uranium-233, uranium-235, plutonium-238, plutoni um-239, and plutonium-24l.

Inventory -- A physical check of reportable-quantity items of accountable materials for serial number, identification, weight, condition, usage, and location.

Material access area (MAA) -- an area containing Category I quantities of special nuclear materials, specifically defined by physical 
bartiers and located within a protected ara, with access restricted to specified authorized personnel only.

Material balanc: area (MBA) -- a numerical disignation assigned by the Safukuards at Technical security Divisinn to an organization, locarion, or spe ififiar ar+a which is authorized ro rupive nuclear materials.

Nut iar mat!: lals - a coliective ters whirli iniludes source mate-

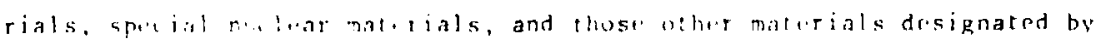

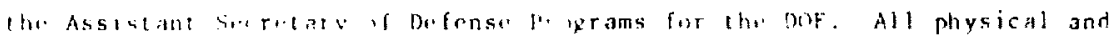

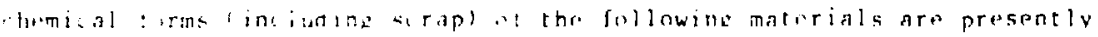
inciud $*$ in:

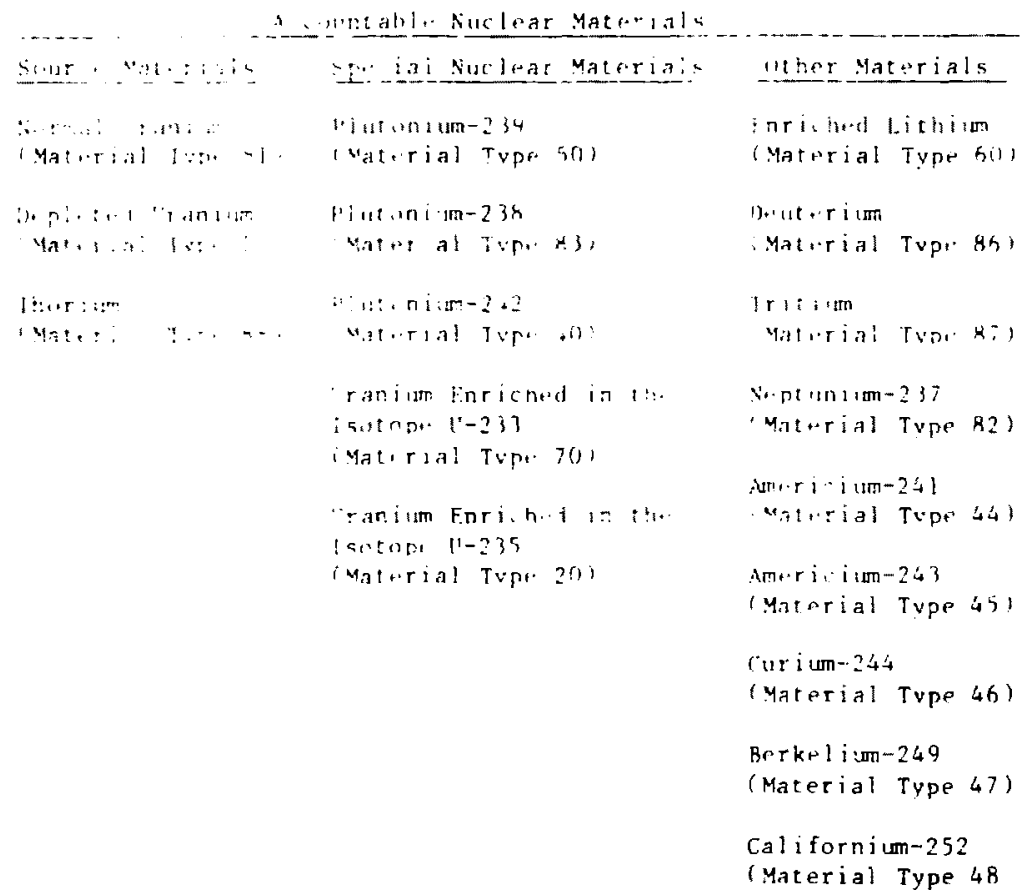

Nuclear materia!s manager -- the designated rmployee in the Safeguards ani Technical Security Division who is responsible for developing 
and directing the ove-all nuclear materials management program at Sandia National Laboratories and who serves as the DOE contact for coordinating materials management activities, such as materials manazement plan pre aration, contractor materials management appraisals, forecasting of nuclear material requirements, matrial utilization programs, risks/ antingency plans for merting inventory targets, reduction of bui art -xpenditures through materials management, "xcess and scrap dispositinn, and andul isal studics.

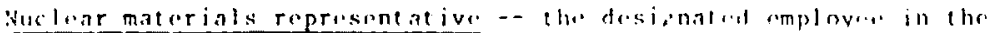
Sil !efuards and Tuchnical security llivision who is responsiblo for . whdimating the rewipt, shipment, control, ans inventory us accountabl.. law loar matarials in the custody of Sandia Nalional latharatorios and who is responsibl. for reporting to the Dut: in aceordance with the reguiresunts specifind in Dot Order 5630.

Protected arra - a specifically defined arati.y, a fenced area, a building, or a segregated arta within a buildinglenclosed by plysical harriers, which mav farm a huffer zone araund one or mark matrial access artus.

Radioactive materials - a collective term which includes all radioisotopes, byproduct materials, radium, radium compounds, and irradiatrd miterials.

Removals - a collective term which includes any activitifs that result in deletions or decreases in the quantitjes of nuclear materials in the inventory.

Scrap -- unirradiated nuclear materials that are not usable in their existing form, are mixed with other materials necessitating chemical creatment to be rendered useful, and which may or may not be recoverable in an economical and safe manner.

Source materials -- a collective term which includes normal uranium, depleted uranium, and thorium (see "nuclear materials"). 
Special nuclear materials (SNM) -- a collective term which includes all isotopes of plutonium, uraniun enriched $i n$ the isotope U-233, and uranium enriched in the isotope U-235 (ste "nuclear marerials").

Special reactor materials -- a collective wrm which includes all physical and chemical forms composed wholly or lareely of beryllium, boron10, halnium, ur zirconium. 


\section{Responsibilities of Users and Custodians}

All organizations involved in activities which utilize nuclear materials assume certain responsibilities with regard to the management, physical control, accountability, and safeguards and security protection of nuclear materials in their possession. Specific responsibilities which using organizations undertake are to:

- Prepare Program and Budget Proposals (DOE Schedules 189 and 189a) for specified prozrams (as required).

- Provide detailed material requirements to Directors for the 12-year forecast submitted annually.

- Perform analytical studies of nuclear matreial requirements and make assessments of risks, contingencies, and options (as necessary)

- Inform the Safeguards and Technical Security Division prompty of any changes in nuclear material requirements or removals.

- Initiate purchase requisitions for radioactive and nuclear materials and provide the necessary information to purchase analysts.

- Designate and approve custodians and alternate custodians for authorized material balance areas (MBAs).

- Furnish justifications (in memorandun form) to the Safeguards and Technical Security Division for the retention of nuclear materials turned in for storage.

- Submit a memorandum annually to the Safeguards and Technical Security Division explaining all scheduled tests and experiments in which nuclear materials are 
anticipated to be expended and/or scrap or excess

materials are expected to be generated.

- Submit Forn SA 6476-ME, "Modification/Expenditure of Nuclear Materials (Exhibit 17 , Chapter $X$ ) 's the Safeguards and Technical Security Division reporting the actual results of tests and experiments in which nuclear materjals were expended and/or scrap or excess materials were generated.

- Prepare shipping paperwork packets for radioactive and nuclnar inaterial shipments.

- Provide the requested naterial usage information to the Safteuards and Technjcal Security Division to satisfy DOF, roporting requirements.

All organizat jans or locatinns which utilize source, special, or other nuclear llatorials (as dofined in Section l) are required to designatr a custwian and aliernate custodian to control and assist in the inventory of mithar materinls within their material balance areas (MBA's). Specific responsibilities which custodians and alternate custodians undretak" are to:

- Fstablich procedures within the MBA to ensure that all Derionnel comply with steurity, safety criticality, assembly/disassembly, modification, expenditure, scrap, transfer, shipment, and accountability rrquirements.

- Meet individually with the Salequards and Technica] Securitv Division staff onco a yoar to discuss updated requirements and any problems encountered during the year.

- Provide delivery instructions and receive nuclear materials transferred to the MBA. 
- Ensure proper safeguards and security protection for materials accountable to the MBA.

- Remain aware at all times of the quantities and locations of special nuclear materials (SNM) accountable to the MBA.

- Maintain records (by serial number and location) of all materials accountable to the MBA.

- Perform monthly physical inventories of materials accountable to the MBA.

- Ensure that transfer documents accompany all transfers of radioactive and nuclear materials to or from the MBA. 


\section{Program and sudget rroposais}

Program and budget proposals required by the DOE are submitted by using organizations involved in non-DMA programs, such as reactor research programs and programs funded by the Nuclear Regulatory Commission. These proposals, submitted on DOE Schedule li:9 (Form SF 921l-F), "Program and Budget Proposal" (Exhibit l, Chapter Y), are intended to provide the DOE with a detailed description of the proposed program along with the budget allocations requirid for the progr $m$ by fiscal year.

For those programs that requi $:$ the utilization of nuclear materials, DOE Schedule 189a, "Program and Bu zet Proposal, Nuclear Regulatory R.search Program" (Exhibit 2, Chaper $X$ ), is submitted in conjunction with DOE Schedule 189 in order to speci y nuclear material quantity requirements for the proposed program. This schedule includes justifications, specifications, and final disposition plans for the materials along with the DOE project number to be charg $A$.

Both documents are completed by using organizacions and forwarded to the Budget and Financial Planning Department, with a copy to the Safeguards and Technical Security Divi ion. Both schedules are ultimately reviewed and approved through the ice-presidential level at Sandia and then forwarded to DOE/ALD for authirization. 
4. Forecasting tor Selected Nuclear Materials, Boron-10, and Krypton-85

On or before December 1 of each yeas, Directors of using organizations are required to submit forecasts for selected nuclear and special reactor materials to the Safeguards and Technical Security Division. Materials for which annual forecasts are required are;

\begin{tabular}{|c|c|c|}
\hline Material Type* & Material to be Forecast & Reporting Units \\
\hline Enriched Uranium & ${ }^{235} \mathrm{U}$ Isotope & Nearest whole kilogram \\
\hline Normal Uranium & Total U & $\begin{array}{l}\text { Nearest whole kilogram } \\
>100 \mathrm{~kg}\end{array}$ \\
\hline Plutoniam & Total Pu & Ncarest whole kilogram \\
\hline $233 u$ & ${ }^{235}$ U I sotope & Nearest whole kilogram \\
\hline Heavy water $\left(\mathrm{D}_{2} \mathrm{O}\right)$ & $\mathrm{D}_{2} \mathrm{O}$ & Nearest whole kilogram \\
\hline Boron-10 & Total $10_{B}$ & Nearest whole kilogram \\
\hline Tritium & Tritium & Nearest whole gram \\
\hline${ }^{238} \mathrm{Pu}$ & ${ }^{238} \mathrm{Pu}$ I sotope & Nearest whole gram \\
\hline Krypton-85 & Krypton & Nearest whole curie \\
\hline
\end{tabular}

* Other materials designated by the DOE may also be added to this list from time to time.

These forecasts, submitted on Form DOE 408, "Forecast of Nuclear Material Requirements" (Exhibit 3, Chapter X), will include probable and firm estimates of requirements for each of the materials for 12 years, including anticipated losses, excess materials, and scrap, along with a narrative description of the program for which the materials are required.

Using organizations are expected to perform the necessary assessment of risks associated with meeting programmatic objectives, health and safety standards, safeguards requirements, etc., and to formulate contingency plans consistent with sound program management. Analytical studies of nuclear material requirements, along with these assessments of risks, contingencies, and options, are reported to the Safeguards and Technical Security Division in conjunction with the annual forecasts. 
Whenever it becomes apparent that forecasted requirements or removals will not occur as scheduled, using organizations are required to inform the Safeguards and Technical Security Division promptly of such changes. On or before the 15 th of the month following each quarter, Directors of using organizations shall submit to the Safeguards and Technical Security Division a narrative decribing the circumstances which precluded obtaining or removing the forocasted materials for that quarter and explaining the effect such changes will have on requirements and removals for each of the following quarters in the fiscal year.

\section{Responsible Organization}

Safeguards and Technical Security Division (NM Manager)

Using Organization (Director)
Action

1. Prepares a letter in mid-uctober, requesting the forecasts and submits the requests, along with Forms DOE 408 and DOE APpendix 7451 , Part I (which provides guidelines for the preparation of the forms), to Directors of using organizations.

2. Reviews the nuclear material requirements for the next $12 \mathrm{fiscal}$ years with using organizatious.

3. Prepares Forms DOE 408 in accordance with the instructions provided in DOE Appendix 7451 , Part I.

3.1 Requirements are reported by nuarter for the first 2 years of the 12-year forecast and by year thereafter.

3.2 The project number, project title, forecasted beginning inventory, receipts, and removals from the prior year (as modified during the year) are furnished by the Nuclear Materials Manager in the Safeguards and Technical Security Division. 
Using Organization

(Director)
Safeguards and Technical Security Division

(NM Manager)
3. 3 Forecasted requirements are reported, including the composition of such requirements and (in the case of items which must be fabricated off site) the total amount of material required for the fabracation as well as the amount of product to be supplied to Sandia.

3.4 Forecasted removals are reported, including the composition of such removals along with anticipated losses, irradiated and unirradiated scrap, and excess material (each jdentified separately).

3.5 A probability estimate is included for each requirement or removal, identified with an "F" for firm or a "P" for probable.

4. Prepares a brief description of program objectives and of known analytical studies and risks/ contingency plans related to the program.

5. Submits the completed Forms DOF 408 along with the program description to the Safeguards and Technical Security Division in late November (by the date specified in the request letter).

6. Consolidates the forecasts by material type and submits the composite forecast to DOE/ALO in early January.

Changes in forecasted requirements or removals must be coordinated with the Nuclear Materials Manager in the Safeguards and Technical Security Division. In particular, any use of forecasted materials in a project or program other than that for which they were originally intended requires prior authorization from the Nuclear Materials Manager. 


\section{Procurement of Nuclear Materials}

Using organizations are responsible for initiating purchase requisitions to obtain radioactive and nuclear materials for approved programs. All nuclear materials procured by Sandia (including those procured for transshipments to another contractor/supplier for use in a manufacturing process) are subject to the reporting requirements specified in DOE Manual Chapter 7451, and selected nuclear and special reactor materials must be forecasted in accordance with the procedures set forth in Section 4 prior to the preparation of a purchase order. In addilion, all forecasted materials procured must be accompanied by a nuclear material draft number assigned by DOE/ALO. Accordingly, all requirements for the purchase of nuclear materials are processed through the Nuclear Materials Representative in the Safeguards and Technical Security Division. Purchase requisitions are prepared by purchase analysts in the Purchasing, Stores, and Traffic Management Department based on information supplied by using organizations and in accordance with SLI 6430, "Procurement of Materials or Services by Purchase Requisition."

Responsible Organization

Using organization
Purchasing, Stores, and Traffic Management Department (Purchase Analyst)
Actior

1. Provides the purchase analyst with the information necessary to obtain the required materials.

1.1 On orders where Sandia-ordered materials are to be used by another contractor in a manufacturing process, special instructions must be included for the disposition of the scrap or a statement included specifying that a request for such instructions will be submitted following processing.

2. Prepares a purchase requisition on Form SA 6430-RD, "Purchase Requisition" (Exhibit 4, Chapter $x$ ). 
Purchasing, Stores, and Traffic Management Department

(Purchase Analyst)
Safeguards and Technical Security Division

(NM Rep./NM Manager)
2.1 Building 819 is designated as the delivery point.

2.2 The Letter " $\mathrm{N}$ " is entered in the Inspection Code block, which puts the Safeguards and Technical Security Division on distribution for the purchase order.

2.3 The designation "Radioactive Material", "Nuclear Material", or "Fissile Material" (see SLI 2047, "Nuclear Criticality Safety") is placed at the top of Material or Service column to serve as a flag for the type of materials.

2.4 On enriched uranium orders, a statement is included requesting that piece-part weights and chemical analyses be furnished with the materials in order that accurace elemelt and isotope weights may be entered in accountabiity records.

3. Submits the completed requisition to the Safeguards and Technical Security Division for special approval.

4. Reviews and approves the requisition, obtains a draft number from DOE/ALO (if required), ano forwards the approved requisition through the purchase analyst to the Purchasing Department for placement of a purchase order. 


\section{Authorization for Custodian Dิtegation}

All organizations or locations using nuclear materials (as defined in Section 1) art required to designate a custodian and alternate custodian to control and assist in the inventory of nuclear materials within their material balance area. The custodian and alternate custodian are approved by the Director of the using organization, and notification of these assignments is sent to the NMR in the Safeguards and Technical Security Division.

Newly assigned custodians/alternate custodians are briefed by the Safeguards and Technical Security Division regarding material accountability and safrguards responsibilities. In addition, all custodians meet individually with the Safeguards and Technical Sreurity Division staff once a year to discuss updated requirements and any problems encountered during the yoar.

\section{Responsible Organization}

Using Organization

(Custodian'Altermote Custodian)

(Director)

Safeguards and Technical Security Division (Auditor)
Action

1. Designatrs a custodian and/or alternatr custodian.

2. Completes radelingtion forms, Form SF 3004-C "Authorization for Rede! coation" (Exhibit 5, Chaptor $X$ ).

3. Approves the custodian and alternatr. custolian and signs the redelegation forms.

4. Forwards the approved forms to the Safeguards and Technical Security Division.

5. Signs and files the approved redelegation forms.

6. Briefs the newly assigned custodian/alternate custodian regarding material accountability and safeguards responsibilities. 
Whenever changes in custodianship occur, the newly assigrad

custodian/alternate custodian is required to submit an approved redelegation form to the Safeguards and Technical Security Division as specified above. In addition, a 100-percent physical inventory of the materials accountable to the MBA is taken by Safeguards and Technical Security Division personnel accompanied by both old and new custodians. This ensures that newly assigned custodians are cognizant of the material for which they are accountable and its physical location. 


\section{Receipt of Materials}

All radioactive and nuclear materials received (except for explosives received in the Igloo Area) are processed through Building 819 by the Nuclear and Explosives Materials Control Section; direct receival of radioactive and nuclear materials by the ordering organization is not permitted. This system allows for the verification of material quantities, permits any necessary resolution of discrepancies in shipping information, and ensures that records of all nuclear materials enter the computerized accountability system.

After the initial prosessing of radioactive and nuclear material receipts, the Nuclear and Explosives Materials Control Section notifies the using organization of the receipt of the materials and requests disposition and delivery instructions. Materials required for immediate use in approved programs are then transferred to the custodian of the authorized MBA for the using organization. Transfers are made only to the authorized custodian/alternate custodian approved by the Director of the requesting organization, although another person may assume temporary custodianship in the absence of both the custodian and alternate custodian. Upon receipt of the materials, the custodian becomes accountable for the materials and responsible for ssfeguards and security protection for the materials (as outlined in Section 8).

Materials received by using organizations are intended to be used in the program for which they were obtained; custodians shall contact the Safeguards and Technical Security Division to determine whether a change in project numbers is required whenever materials are to be used in a program other than that for which they were obtained.

Responsible Organization

Nuclear and Explosives Materials Control section (NM Coordinator)
Action

1. Receives and processes the radioactive or nuclear materials. 
Nuclear and Explosives Materials Control Section

(NM Coordinator) lsing Organization

(Custodian/Alternat?

Custodian)
Action

2. Notifies the custodian of the authorized MBA for the using organization of the receipt of the materials, discusses the assignment of serial numbers, and requests delivery or storage instructions.

3. Prepares a tranafer document on Form SA 2042-D, "Nucloar and Radioactive Matrial Transfre"

(Fxhibit 6, Chapter $X$ ) for the materials being issued.

3.1 Phones the nuclear materinls accountability clerk, 8447150 , to provide the infor mation reouired to complete Form SA 647h-NG, "Transfor Request" (F.xhibit 18 , Chapter $X$ ).

4. Arranges for the physical transfer of the materials and transfer document to thr authorized HBA.

5. Checks the serial numbers on the material identification labels against the serial numbers listed on the transfer document.

6. Ensures that the materials have appropriate identification tags attached.

6.1 The Safeguards and Technical Security Division provides preprinted labels containing the serial number of the materials, net weight, descriptor, raterial type, description, and bar code serial number which are affixed to appropriate color-coded cards (red for SNM, yellow for non-SNM and green for negligible quantities of accountable materials) and attached to the materials, containers, or assemblies. 
7. Verifies that the description of the materials given on the transfer document is definitive.

8. Ensures proper safeguards protection for the materials.

9. Records the date and actual time at which materials are received and signs the transfer document on the Accepted by line.

10. Files the white copr of the transfer document with the accountability records for the MBA.

10.1 If another person assumes
temporary custodianship in
rhe absence of both the
custodian and alternate
custodian, that person is
responsible for turning the
transfer document over to the
custadian as soon as
possible.




\section{Safeguards}

Using organizations having nuclear materials in their custody are responsible for maintaining adequate physical controls and for complying with established security procedures to protect against theft, diversion, sabotage, or vandalism. These procedures are described in various DOF, federal, and Sandia reference documents, including:

- DOE Manual Chapter 5632.1 -- Pliysical Protection of classified Matter and Information.

- DOE Order 5632.2 -- Physical Protection of Special Nuclear Material.

- DOE Manual AL Chapter 24XA -- The DOE Transportation Safeguards System.

- Code of Federal Regulations (CFR), Title 49, Parts 100 thru 189 -- Hazardous Yaterials Regulations.

- Sandia Laboratories Engineering Manual (Chapters 2.11 "Nuclear Explosive SaEfty", and 2.11-] "Control of Nuclear Explosive-Like Assemblies (NELA)".

- Sandia Laboratories Security Handbook.

- SLI 6950-2 -- Shipments.

Additional procedures to establish safecy standards associated with radioactive and nuclear materials are described in other reference documents, including:

- DOE Manual Chapeer 0504 -- Opirational Safety Program Appraisals.

- DOE Manual Chapter 0524 -- Standards for Radiation Protection.

- DOE Manual Chapter 0529 -- Safety Standards Eor the Packaging of Fissile and Other Radioactive Materials.

- DOE Manual Chapter 0530 -- Nuclear Criticality Safety.

- SC-M-70-889 -- Sandia Laboratorios Manual for Industrial Safety, Fire Prevention, and Environmental Health. 
- SLI 2001 -- Industrial Safety, Fire Prevention, and Environmental Health.

- Sli 2048 -- Nuclear Explosive Safety.

- SLI 2047 -- Nuclear Criticality Safety.

- SLI 1030-9 -- Sandia Nuclear Criticality Satety Counittee.

Source and other designated materials are handled and stored in accordance with procedures stipulated by the Environmental Health Department and the Physical Security Standards and Investigations Division. Category I and II Quantities of SNM require special security protection. Special security procedures are also established for any room, building, or portion of a building ir which accumulations of SNM (by ane or more MBA's) are of cazegory I or II Quantitjes.

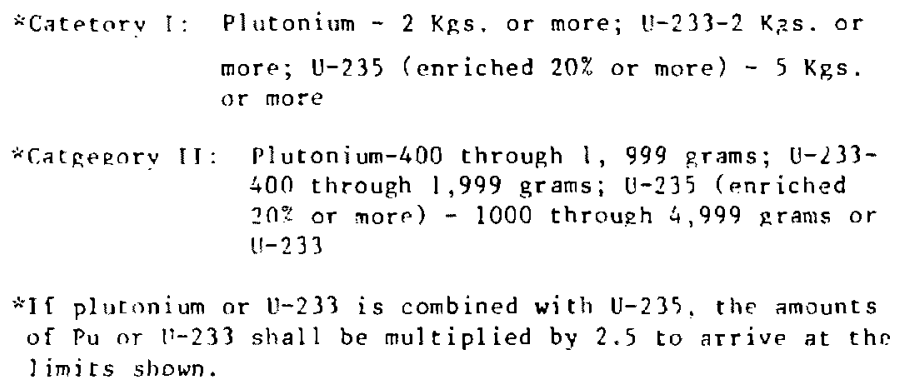

The Saleguards and Technical Security Division assumes the responsibility for informing using organizations of the proper classification of SNM, and both he Safeguards and Technical Security Division and the using organization remain aware at all times of the quantities and locations of SNM accountable to the authorized MBA's. In the pvent that any accumulation of SNM within a specified location exceeds the quantities defined above and in Sec on 1 of this chapter, either the safeguards and Technical Security Division or the using organization immediately notifies the Health Physics Division and the Safeguards and Security Department of this condition in order to provide for adequate safeguards and security protection. 
During nonoperational hours and at all other times when not in use, sNM (including scrap) is stored in approved repositories, unless such an arrangement is not feasible because of size, weight, or continuous experiments. When such an arrangement is not feasible, the responsible supervisor consults with the Safequards and Technical Security Division and the Physical Security standards and Invistigations Division to provide for appropriate safequards and security protection. For calrgory l quantitirs of SNM, approved repositorias consist of vaults or vault-type rooms within n moterial access area (MAA) which is, in turn, located within a protested area. A protected ares is an area which is enclosed by physiral barriers and which is subject to access controls establishod by the phye. ical sercurity standards and Investigatinns Division, approved by the lirallh Physils Division, the Planning Division, the Safrey Fngineering Division and administered by the Safuguards and security bepartment. Acesss to a matorial access area is restricted to specified authorized individuals. Ohir prescribed areas may sorve as approved repositories for category Quantities of SNM, hut such areas require 24 hour surveiliance by two guards as well as advance security approval and procidures.

Category 1 I Quantities of SNM arr also stored in approved reposicories. Approved repositories for Quantities of Category II consist of DOE-approved intrusion alarmed containers, vaults, or vault-type rooms with access restricted to specified autharized personnel only.

Less than Category II Quantities of SNM are stored pither in a locked DOE-Approved Security Container (safe-file cabinets or safes) or in a locked roum located within a protected area.

SNM scrap (which is packaged in appropriate containers) is stored in a security-approved, separately-fenced area within a larger protected area.

All approved repositories should provide a secondary (emergency) means of egress (in conjunction with existing building codes) and should be constructed in such a manner that there is no possibility of flooding. 
Additional procedures which are followed to provide for adequate safeguards and security protection of SNM include the following:

- The operating supervisor of a material access area (MAA) provides to the Safeguards and Security Department a list of employees who are authorized to have access to the area. Under normal conditions, access controls to the MAA are administered by the operating organization.

- Written records are maintained of all persons not on the access $l$ ist who enter the MAA and of all persons who enter the area during nonoperational hours.

- Personal vehicles are excluded from protected areas and material access areas.

- Government vehicles are admitted to protected areas and material access areas only when on official business and operated by a $\mathrm{Q}$-cleared $\mathrm{driver}$.

- All packages, briefcases, and similar items as well as all vehicles are subject to search upon entering a protected area and upon leaving a material access area.

Nuclear materials are issued to using organizations only upon evidence of adequate approved storage within the area to which the materials will be assigned, and criticality-safe conditions are coordinated through the Environmental Health Department. Custodians are responsible for ensuring adequate safeguards for all personnel involved in the handling and storage of nuclear materials by labeling materials as to the type of material, necessary precautions, and security classification. Personnel handling nuclear materials observe all health and safety procedures stipulated in the Envitonmental Health section of SC-M-70-889, "Sandia Laboratories :anual for lndustrial Safety, Fire Prevention, and Environmental Health." 
When in use or in process, Catgegory I and II Quantities of SNM are kept under surveillance by at least two persons, one of whom must have a Q$c l e a r a n c e$ and the other at least an " $s$ " or " $L$ " Access Authorization. Category I quantities of SNM are used or processed only within specified areas, and access to these areas is 1 imited to those personnel required to perform official duties. Less than Category II Quantities of SNM also require adequate safeguards and security protection, and the additional procedures described carlier in this section would normally be followed. 


\section{Records of Accountable Materials}

All custodians are required to maintain a File of internal transfer documents prepared on Form SA 2042-D, "Nuclear and Radioactive Material Transfer" (Exhibit 6, Chapter $X$ ). These transfer documents accompany all transfers of radioactive and nuclear materials both into and out of the MBA and establish the accountability of the materials. Transfer documents for materials transferred into the MBA record the materials which are accountable to the MBA and should be retained as long as the materials remain in the inventory; transfer documents for materials transferred out of the MBA relieve the custodian of accountability and should be retained for one year subsequent to the transfer of the materials out of the MBA.

To assist custodians in material control, the Safeguards and Technical Security Division makes available 5orm SF 6476-N, "Nuclear Material Custodian Inventory Status Card" (Exhibit 7, Chapter $X$ ). Use of this card is optional but, regardless of the cuntrol system employed, custodians are required at all times to maintain an inventory by serial number and location of all materials which ace accountable to the MBA. As a result, records of all movements, assembly, or disassembly of nuclear materials must be kept so that location control can be maintained at all times. 
Each Material Balance Area (MBA) is physically inventoried by Safequards and Technical Security Division personnel assisted by the Custodian/Alternate Custodian of the MBA. The frequency of inventory for pach MBA varies depending upon the types and quantities of materials. MBAs with accountable SNM are inventoried monthly as required by the DOE. MBAs with non-SNM materials only are scheduled quarterly or semiannually, depending upon accountable quantities. Two annual inventorics are conducted of all MBAs, one by the Safeguards and Technical Securicy Division and one by DOE/ALO.

inventories are conducted using bar code readers. Fach item of accountable material has a bar-coded serial number on the identification label which is read with a light pen, recorded in a memory unit, and, following the inventory, transmitted into the computer for reconciliation with the data base records for the MBA (the only exception to individual item identification is sealed containers in storage. Also, in Area $V$, identification card boxes for material that cannot be visually inspected (Serwell, ACRR, SPR, GIF, and GIF Pool), and material in the MAA safefiles are optionally sealed. Sealed containers or card boxes are identified with an identification card consisting of a "Father" bar-cored serial number which, in the computer, references each item serial number sealed in a specific container or box.

The custodian and alternate-custodian are responsible for knowing the exact location of materials for which they are accountable.

Responsible Organization

Safeguards and Technical

Security Division

(Internal Auditor)
Action

1. Checks the master inventory schedule for MBAs to be inventoried during a specific month.

2. Telephones the custodians of the MBAs scheduled to arrange a datp and time to conduct the inventory. 
Using Organization

(Custodian/Alternate)

Safeguards and Technical

Security Division

(Audit Team)
3. Directs the Safeguards and Technicat Security Division inventory team to each item of material for which the MBA is accountable.

4. Visually inspects each accountable item, verifying that the item has the appropriate identification tag at tached.

\subsection{Material identification labels are affixed to appropriate color-coded cards (red for SNM, yellow for non-SNM, and green for negligible quantity items).}

5. Reads the bar-coded serial number on the identification labels using a light pen which records the serial numbers in a memory pack.

6. Transmits the inventory recorded on the memory pack into the computer to reconcile against the master file.

7. Errors may require the audit team to return to the MBA to locate any missing items, or to check transfer documents for items inventoried but not yet transferred on the master file.

8. Reports any unauthorized moves to the director of industrial relations and property protection who then prepares a memorandum for distribution to the appropriate directors.

9. Verifies material located at of site MBAs by telephone, Eollowed by written confirmation from the custodian/al ternate. 
Responsible organization

Safeguards and Technical Security Division

(Audit Team)

\section{Action}

10. Reports losses immediately by telephone to the Safeguards and Security Department, Director of Industrial Relations and Property Protection, Manager DOE/ $S A O$, and Director of Safeguards and Security Division DOF/ALn.

10.1 keports by tolephnne are followed by a written report the next day contoining: location of material when last sern, $n$ descriptinu by chemical and physical form, material quantity, whelher materjal is hazardous, classification, possibility of diversion, dollar value, how loss was detectod, how materia! may have loft facility, and strps taken to locate the missing material.

Materials in the inventory are intended to be used in the program for which they were obtained; custodians shall contact the Safeguards and Technical Security Division to determine whether a change in project numbers is required whenever materials are to be used in a program other than that for which they were obtained.

When DOE audits are scheduled, the Safeguards and Technical Srcurity Division issues a memorandum to all custodians with sprcial instructions stating the period of time required for the DoE physical inventory and requesting that materials not be moved during this poriod unless absolutely necessary.

The Safeguards and Technical Security Division conducts incernal audits continually throughout the year. Once a year, a statistical random sampling technique is used on all of tho material balance areas and, once a year, a $100 \%$ physical inventory of each MBA is conducted. Utilization and storage reviews are also performed during these internal audits, at which time either a justification for retention or a declaration of excess is obtained. 
11. Expenditure, Modification, and Loss of Materials; Disposition of Scrap

DOE regulations require that approval be obtained in advance for any changes in size, shape, form, or weight of nuclear materials. This requirement applies to such antivities as machining of nuclear materials, chemical action on nuclear materials, and destructive tests (either with or without explosives). Once a year using organizations are required to submit a memorandum to the Saleguards and Technical Security Division requesting approval of proposed activities for the following $f$ iscal year and explaining (in narrative form) all scheduled tests and experiments in which nuclear materials are anticipated to be expended and/or scrap ur excess materials are expected to be generated. Following such tests or experiments, the using organization submits Form SA 6476-ME, "Modification/ Expenditure of Nuclear Materials" (Exhibit 17, Chapter $X$ ) to the Safeguards and Technical Security Division describing the results of the test. Based on this form from the using organization, the safeguards and Technical Securily Division submits a request to DOE/ALO for authorization to remove the expended materials from the records and for disposition instructions for the scrap.

Responsible Organization

Using Organization
Action

1. On or before September 1, frepares and submits a memorandum to the Safeguards and Technical Security Division, requesting approval of proposed activities for the following fiscal year and explaining (in narrative form) all scheduled tests or experiments.

1.1 For each activity, the memorandum includes the nuclear material type, the quantities of scrap and/or excess material residues anticipated, the time frame in which the activity will be accomplished, the DOE-approved program and Sandia case number, and the expected level of radiation at the 
Usiug nrganization

Safecuards and Technical

Security Division

(Nas lanager)

(Accountability Clerk)

Using nrganization surface of the materials (if the materials are to be subjected to radiation).

1.2 The completed memorandum is signed by tha division supervisur of thr asing? organizil jon,

1.3 The memorandum inay be amended throughoml the yrar but, for any proposed activity, approval must be obtained prior to conducting thre trests or pxperiments.

2. Submits a memorandum to DOF/Al.O, restating tine just ifications provided by the using organization and requrstins anthorizat inn $t$ remove the materials fram the records.

3. Upon receipt of the reply from DOE/ALO, files thr authorization for futur" use in removing tho expended materials from the records.

4. Performs the schrdulfed activities.

5. Recovers and megsurps the scrap and/or excess material residues remaining after the schrduled a:tivities.

5.1 No nuclear material may be disposed of without prinr authorization from the Nuclear Materials Manager in the Safeguards and Technical Security Divisjon.

5.2 All scrap and/or excess material residues must be measured with acceptable equipment to determine tho weight of nuclear material in tho residues. 
Using Organization

Sarequards and Tirinical

Securicy Division

(NM Manager)

6. Transfers the scrap and/or excess material residues to the Nuclear and Explosives Materials Conirel

section in accordance with the procedures set forth in Section 14 for disposition in accordance with the instructions issued by DOE/AIO.

7. Preparis and submits Form SA 6476MF, "Modification/Expenditure of Nucloar Matorials" (Exhibit 17, Chaptir $X$ ) to the Safequards and Technical Security Division reporting th+2 actual quantities of materials expended, the amount of materials converted to scrap and/or excess matrial residues, and the method by which these quantities were determined.

7.1 This form should include the DOE-approved program and sindia case number for this activity and must be signod by the division supervisor of the using organization.

3. Returns a ipy of Form SA 6476-ME reportine ixpended nuclear material tos thr using organization with a hand-written notation thint the materials have been removed from the accountability records.

9. Prepares an internal adjustment form to updace the master records to reflect the changes reported in th. expenditure form from the using organization.

Following authorization from the Safequards and Technical Security Division Nuclear Materials Manager, nuclear mat using orkanizations, but no nuclear material may be disposed of without prior authorization from the Nuclear Materials Manager or nucle.r materials ripresentative in that division. Scrap and/or excess material residurs generated from such operations must be collected and neasured 
wich acceptable measurement equipment to determine the weight of the nuclear material in the residues. For enriched uranium items, all chips, turnings, and residues resulting from a machining operation must be collected by choroughly cleaning the machine used and the arta surroundine tho machine (including the gloves and filters). Scrap and/or pxcess materinls generated in this manner are reansferred to the vilul lar and Fxplosives Matarials Control Section in accordance with the procolures set farth in siction 14 and disposed of in accordance with the instructinn.. issued by DOF! ALO.

For Juplrew uranium which roquires machining, using organianions may prepare a shop short order on form $5 A$ 6505-WBA, "process and Fabrication Request, Short/Sub work Drder" (Exhibit 9 , Chafter $X$ ), and turn transfor the materials to the Nuclear and Explusives iaterials Control Secion fwo transfers them to the Toxic Shop for the requirel machuning operations). After the required machining has bron performord, the finishod pirces are reissued to the using organization in accordancr. with the procedures specified in section 7, and the scrap which has bern E.n.rated is processed by the Nuclear and Explosives interials rontrol Section for burial or ather disposition authorized by nof:Aln.

Accidental losses of nucloar matorials must bo reported immediatoly by telephone to the Safeguards and Tectunical Sicurity Division and followed by a memorandum (siened by the division suprrvisor responsible for the materials) which explains the circumstances rosulting in thr loss and provides serial number identification of the matrials involved. 
12. Assembly/Disassembly and Movement

In order te adjust accountability records, using Jrganizations are required to complete Form SA 6476-A, "Record of Assemily/Disassembly and Movement" (Exhibit 9, Chapter $X$ ), whenever parts comprised of or containing nuclear material are assembled or whenever assemblies containing nuclear material are disassembled. One copy of the completed form is forwarded to the Safeguards and Technical Security Division where accountability clirks upiate the serial number, asserubly serial number, and other information for the materials, and one copy is retained by the authorized custodian to update the accountability records for the MBA. 


\section{Storage of Materials}

Nuclear materials shich are required by using organizations for approved programs are issued only upon evidence of adequate approved storage within the area to which the materials will he assigned. Approved repositories for the storage of nuclear materials as well as safeguards and security requirements for the protection of nucloar materials are describad in Section 8 .

Nuclear materials which are not immediatcly required for approved programs are turned in to the Nuclear and Explosives Materials Control siotion to be held in storage for future use. lising organizations are responsible for initiating the transfer of nuclear materials to the Nuclear and Fxplosives Materials Control Section for storage in accordance with the procedures set forth in section 14. Nuclear materials are stored for a specifif retention period which is justified by the using organization at tho time of storare on Form SA 6476-ND, "Nuclrar Materials storage Justification."

Responsible Organization

Using Organization
Action

1. Prepares a Form SA $6476-N D$ justifying the need for retention of the nuclear materials to br stored, and obtains tine required approval level stated on the form for the retention period requested.

2. Prepares a transfer document on Form SA 2042-D, "Nuclear and Radioactive Material Transfer" (Exhibit 6, Chapter $X$ ), for the nuclear materials being transferred for storage.

2.1 The preparer records the date and actual time at which the request for transfer is made and signs the transfer document on the Transferred From line. 
Nuclear and Explosives Matorials Control Section (NM Coordinator)

Safeguards and Tochnical Security Divisjon (Internal Aud itor)

\subsection{The transfer document and 2 copies of the approved Nuclear Materials Storage Justification Form must accompany the materials moved to the Nuclear and Explosives Materials Control Section}

3. Transfers materials to the Nuclear and Explosives Materials Scction for storage in accordance with Section 14 .

4. Arranges for the phvsical transfer of the nuclear materials, the transfer document, and the just ification form.

5. Stores the nuclear maturjals.

6. Forwntds the pink copy of the transfer document and 1 copy of the justification form to the Safeguards and Technical Security Division.

?. During internal audits, reviews the status of nuclear materials in storage with the using organization and obtains pithor a justification for continued retention or a declaration of excess.

Using organizations may withdraw nuclear materials from storage by telephoning the Nuclear and Explosives Materials Control Scction. Upon receipt of this call, the Nuclear and Explosives Materials Control Section transfers the materials to the using organization in accordance with the procedures specified in Section 14 . 
14. Internal Transfer and Movement of Materials

In order to ensure that adequate control and proper accountability of radioactive and nuclear materials are being exercised at all times, internal transfers and physical movements of materials are coordinated through the Safeguards and Technical Security Division. Internal transfers occur whonever:

- Materials are transferred by the. Jear and Explosives Yaterials Control Section to using organizations.

- Matarials are transferred by using organizations to the Nuclear and Explosives Materials Control Section for storage, machining, or shipment.

- Materials are transferred directly betwoon MRA's.

All incirnal transfers of materials must be documented on Form SA 2042-ri, "Nucliar and Radioactivc Material Transfer" (Exhibit 6, Chapter X).

Nuclear material transfers are requested by telephoning the accountability clerk, ext. -7150 , following completion of the transfer documcnt. To initiate the transfer, the accountability clerk requires the information on Form SA 6476-NG, "Transfer Request" (Exhibit 18, Chapter $X$ ). The accountability clerk queries the computer file to verify that the receiving organization is authorized to receive nuclear materials and whether or not the quantity of material being transferred will create a Category $I$ or II situation which will require the two-man rule and 24-hour guard service.

The transfer request data is input to the computer via terminal and the Nuclear Materials and Explosives Control Section periodically queries the computer for open transfers on a terminal in their office. A nuclear material coordinator schedules the material transfer after telephoning both the sending and receiving custodians. 
A nuclear materials coordinator must either physically move the material, or arrange with the transportation division and accompany the movement .

Transfers are made only to authorized custodians approved by the director of the receiving organization, although another person may assume temporary custody in the absence of both the custodian and alternate custodian. Upon receipt of the materials and the transfer document, the receiving custodian becomes accountable for the matcrials and responsible for safety and security protection for the naterials (as outlined in Section 8).

Responsible Organization

Sending Organization (Custodian)
Action

1. Prepares a transfer document on Form SA 2042-D, "Nuclear and Radioactive Material Transfer" (Exhlbit 6, Chapter $X$ ), for the materials being transferred.

1.1 The preparer records the date and actual time at which the request for traisfer is made and signs the transfer document on the Transferred From 1 ine.

1.2 If the "Storage" block is checked on the SA 2042-D as the reason for transfer, the preparer at taches a completed Form SA 6476-ND, "Nuclear Materials Storage Justification" (Exhibit 10, Chapter $x$ ). Naterial will not be accepted For storage without the justiEication form.

1.3 jf material is to be transferred as an assembly, the preparer completes the assembly number block on Form SA 2042-D, otherwise the computer disassembles all assembled units at the time of transfer. 
Sending organization

(Custodian)

Snfrguards and Technical

Security Division

(Account ability Clerk)

Nuclear and Explosives Materials Control Section (NN) Coordinator)

Moving Organization

(Material Handler)
1.4 The Weapon Training Division uses their own storage form, in lieu of SA 2042-D, to move material to and from storage.

2. Forwards green copy of SA 2042-D to Safeguards and Technical Security Division as a suspense copy.

3. Phones the nucluar materials accountability clerk, ext. -7150 , to provide the information required to complete Form SA 6476-NG, "Transfor Request" (Exhibjt 18, Chapter X).

4. Records dat on the "Transfer Request" form.

5. Inputs the transfer request data on the terminal screen titled

"Request/Display Transfer" to verify the data provided.

6. Queries, via terminal, for apen transfers.

6. I If special instructions call for heavy equipment, health physics participation, Category I or I I quantities of SNM, or weapons requiring security guard escort, arranges with the appropriate personnel for movement of the material.

7. When ready to physically move mate-rial, inputs data on the terminal screen citled "Initiate Transfer."

8. Procesds to sending MBA.

9. Checks item label serial numbors against those recorded on the transfer document.

9.1 If they agree, signs the transfer document, recording date and $t$ ime. 


\subsection{If they disagree, requests custodian to correct the trans- fer document, then signs and records date and time on the corrected document.}

Sending Organization (Custodian/Alternate)

Nuclear and Explosives Material Control Section (NM Coordinator)

Receiving Organization (Custodian/Alternate)

Nuclear and Explosives Material Control Srction (NM Coordinator)
10. Gives the goldenrod copy of the transfer document to the custodian of the MIBA sending the meterial.

11. Retains the goldenrod copy to relieve the sending MBA of accountability.

12. Moves the material, with the white, yel low, and pink copies of the transfar ducument, to the receiving MBA.

13. Checks the matrial to ensure that the transfer document accurately reflects the matrial label serial numbers.

14. Sigris the remaining transior documint copies recording date and timf, and retains the white copy.

15. Ensures proper safeguarts protection for thr. matirials.

16. Delivers the pink copy of the transfer document to the Safeguards and Technical Sicurity Division.

17. Retains the yellow copy of the transfer document to file in the Nuclear and Explosives Material Contral Section office.

Transfers of materials to the Nuclear and Explosives Materials Control Section for storage, machining, or shipment and transfers to offsite MBA's are accomplished by the same procedures as set forth carlier for transfer between MBA's. Offsite MBA's are established prior to transfers of materials through discussions with the Nuclear Materials Representative in the Safeguards and Technical Security Division and with the prior approval of DOE/ALO. 
Military flights originating from $K i r t l a n d ~ A F B$ normally require the transfer of materials to the military in accordance with the procedures set forth in Section 15; the owning MBA retains accountability of materials on short-term ( 48 hrs) military flights only. Drop tests at Tonopah Test Range require a transfer of materials to Tonopah (MBA 37) from where the drop test materials are subsequently transferred back to the Nuclear and Explosives Materials Control Section. Othir drop tests or miljtary flights not originating from Kirtland $A F B$ requite a transfer of materials to the military in accordaner with the procedures set forth in section 19. 


\section{Shipment of Materials}

In order to ensure strict compliance with DOE and Department of Transportation regulations, all radioactive and nuclear materials requiring shipment off site are processed through the Nuclear and Explosives Materials Control Section. SLl 6950-2, "Shipments," provides guidelines for the shipment of these materials, and SLI 6950-4, "Movement of Classified Material," provides supplementary information in the case of classified materials. In addition, shipments to Rocky Flats or to the DOD require special procedures to br followed which are rxplained in this section.

Handcarried materials requite the same paperwork to bo processed chrough the Nuclear and Fxplosives Materials Control Section as for ordinary shipmints. This is necessary in arder io unsure conpliance with DNE and DOT regulations, including the following:

- Radioactive materials cannot be handcartied on passengercarrying aircraft.

- Plutonium cannot be transported on any aircraft.

- Radioactive materials cannot be carried or transported in personal vehicles; only government vehicles car be used for this purpose.

If shipment is going to a company or institution other than a License Exempt DOE Contractor, the organization responsible for shipment must obtain a copy of the Recipients License prior to shipment if the Nuclear and Explosives Materials Control Section does not have a copy in file. 
Responsible Organization

Using Organization (Property Clerk or Control)
Action

1. Prepares a shipping paperwork packet, consisting of the shipper on Form SF 6951-A, "Property Action" (Exhibit 1l, Chapter $X$ ), the hazard sheet on Form SA 6550E.A, "Information for Hazardous Material Shipments" (Exhibit 12 , Chapter X). Form SA 2042-D,

"Nuclear and Radinactive Matrrial Transfer, and a copy of the recipients license althorizing receipt of the material being. shipped.

1.1 The shipper must be marked "Radinactive Material -Irradiated," "Radioactive -SS Matrrial," "Radioactive Material," or "Fissile Material" (see SI.1 2047. "Nuclear Criticality Safety"), as approprints.

1.2 Using organizations must determine whother the shipment requires a courier (soe Sla 6950-2, "Shipments") and must state this on the shipper.

1.2.1 When a rourier is required, a copy of the shipper is forwarded to the Traffic Management Division as an advance copy to allow courier service to be arranged.

1.3 Nuclear material control clerks are assigned to the. weapon systems divisions (Building 809) and to the reactor area (Area v) to prepare the shipping paperwork in those areas. 
Nucleas and Explosives Materials Contrul Section (NM Coosdinator)
2. Transfers the materials and paperwork to MBA 0l (assigned to the Nuclear Materials Concrol Section for materials being held for shipment) in accordance with procedures set forth in section 14 .

3. Completes the ruquirad paperwork and arranges for the packaging and shipment of the materials in conjunction with the shipping and Receivine Division, the Hralth Physics Division, and the Trafri: Manapement Division.

In aldition to the standard paporwork. shipments to Rocky flats recuire Form Rf-43940. "Authorization to Ship SS ur Nun-SS Material"

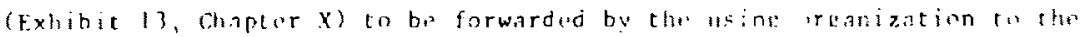
SSMr in the Safeguards and Technical Security Division priot to shipment. The SS:R thun submits this fort to Rocky Flats fir approwal. This

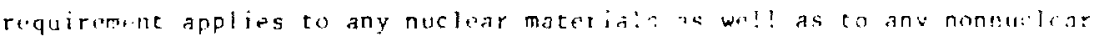
materials that have ber exposed to rationaclicins teut as fissiun products, other actinitua, we tritian). The requirement also applias to

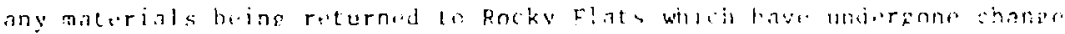
siner they wers shipped from Rocky flats. lpon reopipt if authorizatiun to ship from Ricky flats, shipment of the raterials procosis in aciordane. with the procedures sit forth arlier in this soction.

Shiprents of nuclear materials to the bon mut have prior authorization, as stipulated in Section 9 of Technical Manial TP 100-1. "Supply Management of Nuclear Weapons Material." Frior authorization may consist of one of the following:

- A telecon from the project engineer to his councerpart in the DOD requesting him to initiate a requisition. This requisicion provides definition of requirements (including authorized shipping channels and recipients) and is processed through field Command, DNA (FCONA) to DOE/ALO. FCDNA is the only DOD aency recoenized by the 
DOE for the negotiation of transfers of nuclear weapons materials between DOE and DOD activities, and final negotiations are made by FCDNA. The approved requisition and memorandum from the Weapons Production Division, DOE/ALO, must be received by the Safeguards and Technical Security Division prior to shipment.

- A letter from the project engineer to the weapons Production Division, DOE/ALO, (with a copy to the Safeguards and Technjcal Security Division) drefining any change in raquirements or supplying any supplementary information needed to support a Memorandum of l'nderstanding, Joint Test Agreement, or Joint Operating Plan. A copy of the reply authorizing shipment must be received by the Safeguards and Technical Security Division prior to shipment. 


\section{Exporting Accountable Nuclear Materials}

\section{lf. l Procedures for Exporting}

Mateials may be shipped to a non-U.S. Incation in coniunction with a NRC agroement, or by DOE authorization.

\subsection{NRC Agreeme'nt}

The sending stganization will (l) complet" form "kequest for Foreign Contract Number", svailable in Division 3434, and mail to lnion Carbid. (.nrp., Oak Rider, Tenn. (mailing address on form), (2) upon receipt of the foreign concract number from onk Ridge, complete Furm NRC-?, "Appliration for License to Export Nuclear Material and Foquipment", available $i$ Division 3434 (instructions for completing and mailing on form), a: (3) Laphone tisr Dipartmint of Commeren (FTS Ne. 2012-377-4777) to w ain the shipment and abtain the authorization code which must bu insert in the authentication hlock of Form 7525-v, "Shippre's Fxport De:lars: in". prepared by the Traffic Manaement Division.

Whar the contract number, 1 icense number, and authorization code have beon reatived, follow the procedures in section !h, 4 .

\subsection{DOF. Afproval}

The sending organization will (l) complete form "R. quost for Foreign Contract Number", available in Division 3434, and mail to Union Carbide Curp., Dak Ridfe, Tenn. (mailing address on form), (2) rrepare a memorandum addressec to D. L. Krenz, Special Programs livision Director, DOE/ALO, requesting authorization to ship material. The memorandum, must include the following: Description of material, how it will be used, length of time it will be used and benefits to be rerived, and whether it will be returned. At ach a copy of the Sandia co : ract, or reference any correlation to another contract or international igrement. 
When the contract number has been received and the memorandum prepared, follow the procedures in Seclinn 16.4.

\subsection{Internal Procedures}

\section{Responsiblo Organization}

Sending Organization
Nuclear and Fxplosives Materials Control Section (NM Coordinator)
Action

1. Proparos Form SF 6951-A, "Pi-operty Action", Form SA 6550-rA, "Information for Hazardous Material Shipments", Form SA 2042-D, "Nuclair and Radioactive Material Transfor" transferring material to MBA 01, Blde. BG7 south.

2. Attaches a copy of the contract number, NRC I.icrnse, and Dept. of Commerce authorization code, if shipment is NRC anceoment, or a copy of the contract number and meno io DOF, if DOF. nuthorizod, to the paperwork in step 1.

3. Follows transfer procedures in section 14 of this chapter.

4. Picks up material and paperwork from sending organization.

5. Signs on the "Transferred By" line of the Radioactive and Nuclear Materials Transfer Document.

6. Returns material and paperwork to the Nuclear and Explosives Materials Control Section for processing.

7. Prepares Nuclear/Radioactive Material Packing Slip, Form SF 6476-I, and adds to the shipping paperwork packet.

8. Prepares Nuclear and Radioactive Material Transfer, Form SA 2042-D, transferring accountability for the material to the Packaging Section, MBA 66. 
Shipping and Receiving

Division

Traffic Management Division
9. Prepares Form SA 6550-E, "Hazardous Material Packing and Shipping Instructions." Packages material, completes paperwork, and forwards Form SF 6476 - l, "Nuclear/Radioactive Material Packing Slip", Form SA 6550-E, "Hazardous Material Packing and Shipping Instructions", Form SE 6951-A "Proprety Action", copy of tha foreign contract number, NRC license, Department of Commerce suthorization code if NRC agreenont, or foreisn cont:aut number and $n_{1}+m^{\prime} 3$ to BOE/ALO if DOE authorized, to the Traffic Management Division.

10. Completes five copies of the Shipper's Export declarati.na sigaed by tha Traffic Manasment nivision Supervisor.

11. Forwards the Shipper's Export Declaration requirin: DOE authorization to D. L. Krenz, DOE/ALO, with the memorandum from the sending organizatior. requesting author zation to ship.

12. Lipon reflipt or apprcuad Shipper's Fxport Ceclaration from DOE, prepares Government Bill of Lading, Air Bill (if requirei) Hazardous Material Cercification, Certificate of Registration, and returns shipping paperwork to the Shipping and Receiving Divisinn.

12.1 If NRC liconsed shipment, and DDE anproved, sends the following documentation to the Shipping and Recejving $L$ ision for immediat" sipment:

a. Government Bill of Lading

b. Air Bill (if required)

c. Hazarious Material Certification

d. "inper"s Fxport Declaration

e. I rtificate of Registration

f. NRC ijcense. 
Responsible organization

Shipping and Receiving Division

(Packaging Enginerr)

Nuclear and Explosives Materials Control Section (NM Coordinator)

Traflic Management Division

\section{Action}

13. If awaiting DOE authorization. Calls Nuclear and Explosives Materiais Control Section when packaging is completed.

14. Picks up packaged material and stores pending DOE authorization to ship.

15. Upon roceipt of approval from Dol:, forwards the Government Bill of Lading, Air Bill (if required), Hazardous Material Cretification, Fxport Drelaration, Certificate of Registration, and copy of Dof: approval leter to thre Nurlear and Pexplosives Materials control section in authorize shipment. 


\section{DOE Reports}

The Safequards and Technical Securitv Division assumes the primary responsjbility for proparing and issuing reports required by the DOE, basod on tho intormation obtained from using organiations and computerized accountability records. Hrief descriptions of the reperts requiring input from using orgarizations along with thr information nowded from these organjzations ari us follows:

Appraisa! utilization (anmul report prior l: llw appraisa! dalu.

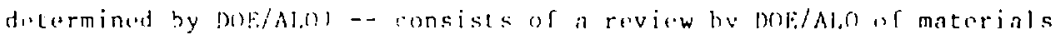
management astivities, puliri, procedures, and perfornance crectivenoss i complving with (x)l: raterials management requirmants.

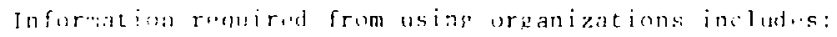

- Justiti aliuns Cor materjals beje uswel and for maturiale hring hold in storage for future use in DOFappriati prisicis.

Aaterials anagument plan (annual report due Mily 15 ) - consists of a report based upon mat serial rosources required and amual nucleat material allotmines.

Information reauired from using organizations includes:

- Matorial usago schedulos by project.

- Forezast changes (to be reported to tha safeguards and Technical Security bivision as soon as they are known).

- Documinced analyses of using organization considerations in arriving at decisions regarding current inventory levels, percentage of spares required, etc., including the cansidurtions given to anticipated risks, contingency plans to combat significant risks, options 
considered to reduce material budget expenditures, and options and risks that could be taken to reduce target inventories.

Assessment report (annual report due December 15 based on the September 30 inventory) -- consists of a report of material element and isotope weights by composition code, enrichment range, and project numbir, with coments regarding current usagr, intended usage, and subsiguent disposition of matorials.

Inforination ruquired from using oratizations inciuds:s:

- Ixplantions of current prograns (with a breakedown a? material inventory usage) and of future programs (with . benkelown of naterials being held in storage for anch proseram)

- Justificatien for uny materials boing hold in storaze for which usage is not firm.

Status of Inventory (quarter)y report) -- consists of a rrport of inventory quantities by material type, COEl line number, and project number.

Information required from using organizations includes:

- Changes in material composition.

- Changes in material usage requiring a project number change.

Excess/Scrap Declarations (periodic reports, as required) -- consists of a memorandum declaration of excess/scrap reported by inaterial type, description, quantities, and irradiation level or else consists of a uranium scrap evaluation report (on appropriate forms). 
Information required from using organizacions includes:

- Declarations of excess/scrap requiring disposition.

Forecasts -- Annual forecasts of nuclear material requirments are developed and submitted to DOE/ALO in early January on Form DOE 408 , "Forecast of Nuclcar Material Requirements." Forecasts include quarterly requirements by material type and isotope weight for the two succeeding vears, and annual requirements for 10 additional years. Forecasts also include scheduled returns,

Inturmation required from using organizations includes:

- Organizational material requirements.

Write. Off -- Materials removed from the inventory records are submitend monthly to DOF. This repert inciudes the raterial type and type of expenditure (ID, NOl, RT or DECAY) by project number, JAF number, 741 number, flement and isotope weights.

Information renuired from using organizations includes:

- Itemizes rxpenditure and modificatzon losses reported on Form SA 5476-ME, "Modification/Expenditure of Nuclear Matorials." 


\section{Special Procedures}

18.1 Procedures for the Receipt of Radioactive and Nuclear Materidls in Tech Area V.

All radioactive and nuclear materials received in Area $V$ must be processed through the material access arca (B1dg. 5592) by tho custortian/ alternate custodian or the Control Coordinator. Direct recoival of matrrials by using personnel is not promittod.

Responsible Organizalion

Arra $V$ Control Division (Custodian/Control Coordinator)
1. Checks serial numbers on the material iclentification label.; against the numbers rreorded on the transfor docimont.

2. Signs transfar focument for receipt of materinl and retains white copy in area $v$ records filn.

3. Stares material in Material Accress Area (MAA) until requested by user.

4. Transfers material within Aren $V$ as required and records transfer in accordance with Section 10 .

\subsection{Procedures for the Transfer and Record Keeping of Radioactive and} Nuclear Materials in Tech Area $V$.

Records of Internal and External transfers of material aro maintained on the monthly inventory listing issued by the 5afeguards and Technical Security Division, and a file of Form $5 \wedge$ 2042-D, transfer documents, for transfers in and out of Tech Area V. 
Area V Control Division (Custodian/Control Coordinatur)
1. Maintains a file of Form 2042-D white copies which represent all it ems transfirred into the Area $\checkmark$ inventorv, and a file of Form 2042-1), woldentod copies which represultes matorial translored out of thr Area $V$ inventory, with a sopalta íl, of material l ransforrat to storathe.

1.l krequest $\because$ as required, storater invente $1 \because$ l $\mathrm{i}$ st ings from the Salenenads and Tuchnical Sururity nivision af al?

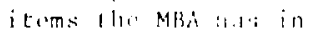
storis..

2. Filas a colly al the provions months inventory list ing and notes he following information ol the sorial nutrerer lines af inarerial transfirrid intirnally:

2.1 Vam, and urganization

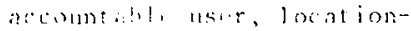
buililine ant rom, issur. d.at?.

3. Isores butome aceount ablo for material tamisturred fol lhem, and rosponsible for rerepine the custodian apperisul of any cahsegueat malurin! novement, modifirntiun, ar mprometure.

18.3 Procrdanes for Inventory of Accountable ivialwar Materials in Tech

Inventory procedures in section 10 o! this ahaptir are rollowed. $18.4 \frac{\text { Tech Area } V \text { Reporting Procedures Cor Aticicipated Losses During }}{\text { Experiments or Machining }}$

Dof regulations require that approvai be ohtained in advance for any changes ir size. shape, form, or weight of nuclear interials. 
llsing rirganization

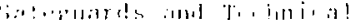

(j...urily hivisinl

(? $4 ., 11,1,1 \cdot r)$
1. Prepares Lorm SA 5476-Mri. "Moditication/texpenditur. nt ind lan Materials" (Fxilibit 17, "aptur X)

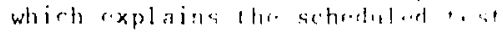

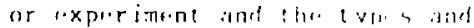

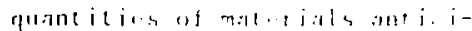

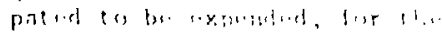

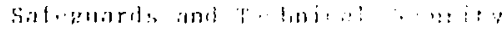
l)ivision.

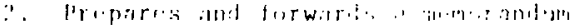

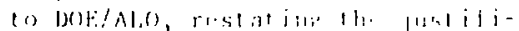

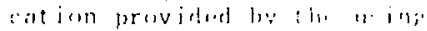

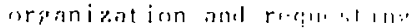

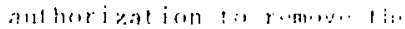

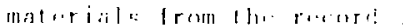

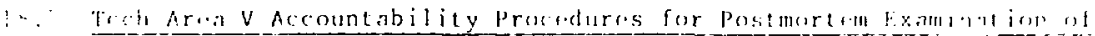
Propiments containing SNM

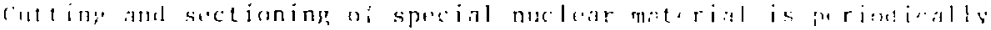
:-rpuir.el in the priparation of experioments.

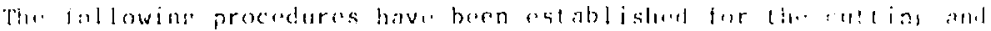
suletinning operations and postmurtem rexaminations:

\section{Rusponsib]r. Ormanization}

Arra V Control Division

(cisstodian)

$($ Experimontor
Action

I. Transfers inatorial from thr Material Accoss Aria (MAN) to cxperimenter and notes experiinenter's name and locition change.

2. Mainkajns a log by surial number of materials recioved.

3. If material is cul, mosplos weight of romaining parts and residue cleaned from saw area or glove box and saw blado.

4. If modified material is not weighable due to the condition of the sample, estimates woights of the various pioces, hased upon the width of the sow hlade. 
5. Sketches material in log book illustrating location of saw cuts.

6. Reports actual expenditures on Form SA hitis-yl:, "Modification/ fixpendicure of Nuclear Materials", a the Safuguards and Trchnical Sncurity Division through the sustodian.

7. Wrishts of now itrms and rosidur plus loss atust equal boginning woight of oriminal serially mumbered itrin.

8. Items will be placed in plastic bags, or ochre suitable containers, with the identifying serial number f Harly uisibl. on the outside, with ranisired or rest imatrol weights.

Salouarals and Terindical Sreurily Division

(ivis Manager)

$($ A:coumentilit: il.rk)

l'sing rraanizal i i.n

(Cisetudian)

9. Priparrs inventary adjustment form (IAF) to molify and upelate computer recorils.

11). Lpetates thr computer records and

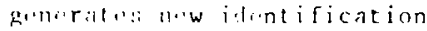
l. ble is.

11. Transfors residue to custodian subseguent to repurling changes to Safrguard: and Tichnical Security Division and apolying labols to now items.

12. Transfers liaterial lo custodian following postmotem rxamination.

13. Collects residue from several experiments in a single container if the rnrichment is the same, and $r$ ruests serial number label change by reporting the consolidation in a memoranduri to the Safe: ards and Technical Security Division. 
Using Organization

(cuscodian)
14. Accountability riacoris for

materials in expiriments must be. detailed and explajn modjfications, wright changes, identification labrls, residur ganeratrod, and physiral location.

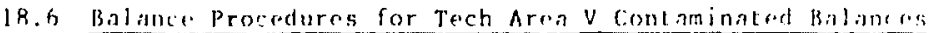

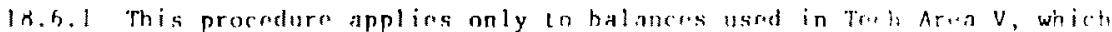
are rontaminat.d nol/or in a contaminated anvironment. (cuntaminatred =

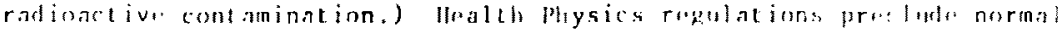

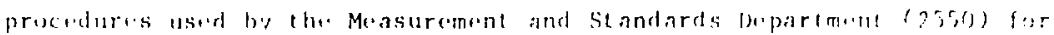
salibration, for those halancrs not contamillatul and/rer in a cont minat.

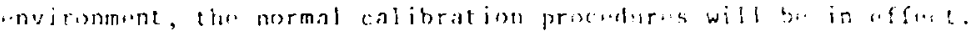

18.h.l.l For mach Balance that will he placed in a glaw bux, rlave brix line or sterel containment box (hot toll), a set of class s standards (sem ATTACHMENT I for definition) shall be obtainfol and shall r...rin assoriatint with that balance through its services lifo.

18.6.1.2 For all other balances which may be cont iminatorl but are not in

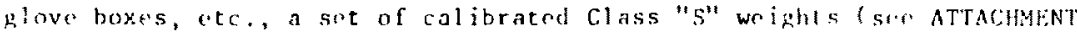
II) will be maintained in Tech Area $V$ for calibration chreks.

18.6.2 Tire balances will be maintainod by usors for thrir own use, which normally requires greater accuracy than accountability wrighing. (For accountability purposes, it is undarstood thit tho accuracy requiret is to be $\pm 0.5 \mathrm{gran} b e$ low $1 \mathrm{~kg}$ total and $\pm \mathrm{l}$ gram above $1 \mathrm{~kg}$.$) Therpforp, a spor$ check of accuracy and sensitivity of the balances just prior lo their use for accountability weighing will verify their integrity.

18.6.3 Weighing procedure for each woighing or series of wrighings.
a. Check balance zero point and adjust if mecessary.
b. Obtain approxinate weight of material.
c. Remove sample. 
18.6.4 Check balance in the range of the approximate wright obtained in "b" above. For "xample, if woight obtained in "h" abovr is 25.6 grams.

a. Using Class "s" woight $(s)$, place 25 g wn balance.

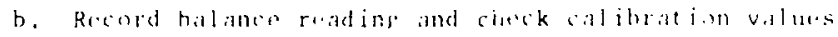
i) witiphts.

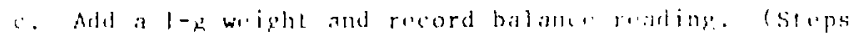
b and o are an accuracy chack.)

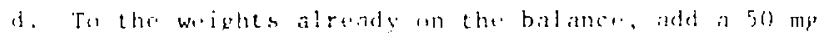
weight amel record balaner reading. In particular, record the change due to addition af 4 la. $50 \mathrm{mg}$ weight. (This is the rheck of thr baince. sinsitivity.

f. Sura [alibration values of the weights used and compare to balance ruadings. These values should be the ame within $\pm 2 \mathrm{mr}$.

f. Wigh samples accuratoly and record weight.

g. Recheck balance zero on complotion of weighing.

\subsection{Addenda I - Weight Classification}

Weights may be divided into fnur groups according to their use. These are listed below together with the class of adjustment as prescribed by the National Bureau of Standards. An example given in each case shows how the tolerance varies for a $10-g$ weicht in each class. Henry Trocmnec, Inc., manufactures weights in every class listed except class $J$.

Specifications for all commonly used laboratory and trade weights are covered in National Bureau of Standards circulars. Class $M, S, S-1$, 
$P, Q$, and $T$ sprecifictions are detailed in NBS circular 547, snction 1 . Class $A, B$, and sprcifications are covrerd in NBS circular No. 3, issued in 1918, now out of print but under revision. Class f spreifications ar. rontaind in NBS handbook 105.1. All Tromer woights aro manufactured in strict accurdance to the specifications nutlinfel in thesi circulars. Fur sperific information about construction, aljugtment, marking, rete. of anv wriphts in these serios, write or phome 11 .

\section{PREC:ISION I.ABGHATORY STTANIAROS}

SIISSS I

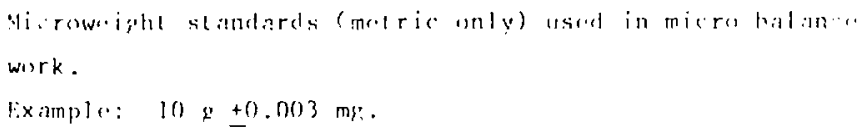

CIASS "M High-procision sojuntific standards (motrir only) usod as refiremed, and in high-constancy work.

Eximplo: $10 \mathrm{~g}+0.050 \mathrm{mg}$.

Class $s$ Seintific standards uscel for reforence, calibration and procision analytical work in physical and chomical laboratories and in assay work. Available in metric systern only.

Example: $10 \mathrm{~g}+0.074 \mathrm{mg}$.

CLAss 5-1 Laboratory standards used for routinas analytical and precision, nonmetric work with balances using quick-weighing devices, such as a chain. This class bridges the gap between

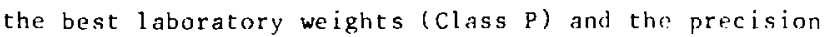
laborator: standards. Available in metric system, or in other systems on special order.

Example: $10 \mathrm{~g} \pm 0.25 \mathrm{mg}$. 
18.8 Addenda 2 - Metric W. ights

One Set (18) Metric Weights

File No. 5228A

Truemner, Class $\mathrm{S}$

F/N S-248 470

Assumed Density: $\quad 7.84$ gicm

\begin{tabular}{|c|c|c|}
\hline $\begin{array}{l}\text { Nominal } \\
\text { Mass } \\
\end{array}$ & True & $\begin{array}{l}\text { Mass Correction } \\
\text { Mil ligrams }\end{array}$ \\
\hline $\begin{array}{l}10 \mathrm{~kg} \\
10\end{array}$ & & $\begin{array}{l}+124.939 \\
+\quad 86.785\end{array}$ \\
\hline $\begin{array}{l}5 \\
3 \\
2 \\
i\end{array}$ & & $\begin{array}{l}+44.061 \\
+\quad 34.800 \\
+18.922 \\
+11766\end{array}$ \\
\hline $\begin{array}{l}51+0) \\
300 \\
200 \\
100\end{array}$ & & $\begin{array}{l}+5.373 \\
+\quad 3.666 \\
+\quad 3.868 \\
+\quad 1.008\end{array}$ \\
\hline $\begin{array}{l}50 \\
30 \\
20 \\
10\end{array}$ & & $\begin{array}{l}+\quad 0.532 \\
+\quad 0.326 \\
+\quad 0.162 \\
+\quad 0.070\end{array}$ \\
\hline $\begin{array}{l}5 \\
3 \\
2 \\
1\end{array}$ & & $\begin{array}{l}+\quad 0.013 \\
+\quad 0.051 \\
+\quad 0.002 \\
+\quad 0.033\end{array}$ \\
\hline
\end{tabular}




\subsection{Area V Hat Cell Facility}

The Hot Cell Facility consists of two laboratories, the hot-cell laboratory and the glovebox laboratory, which are used for assembly and disassimbly of experiments containing SNM. The choice of location within these facilities depends on the radiation level of the material and the sansitivity of the materiol to water vapor and/or oxygen.

A detajled description of thr two laboratories can be found in thr Saretv Amalysis Report (SAR) approved by DOF/ALO.

A hardhack, bound log book containing individual vxperiment informetinn will be filed in rach laboratory for tracking materials throuph the various processes so that weights of modified parts, scrap, and lose can b. balanted with beginning weights.

Aron V control of maierjals to be modified, as authorized by thr. Salopuards and Technical Security Division, 3434, will be mointainrod in accordanew with the following procedures:

Responsibl: Organization

Aria C Con al Division (Fyperim, nten)

Sefis. Secur. (NM vanager)

\section{Action}

1. Prepares request pretion of Forri $S A$ G476-ME, "Modifi: : ion/Expenditure of Nuclear Materials."

2. Sends Form SA 6476-ME to the Nuclear Materials Manager, 3434, for approval.

3. Reviews materials and explanation of modification/expenditure to be performed.

4. Approves form by signing and dating.

4. I Files copy in separate Area $V$ modification/expenditure file.

5. Returns approved copy to Area V. 
Area $V$ Control Division (Experimenter/Control Coordinator)

Hot-Cell Facility (Experimenter/Contro) Coordinator/Technician)
Action

6. Experimenter files copy of Form SA 6476-ME and the Control Coordinator moves authorizcd material, when necessary, in approved shielded cask to the hot-cell facility.

7. Control Coordinator inputs the change in location of materials to the Nuclear Materials Accuuntability system

8. Experimenter/technician ve-ifies weight of materials, if weighable, by following balance procedures in paragraph 18,6 .

9. Experimenter/technician records the following data in laboratory log book during modicication.

9. 1 Modification form number

9. 2 Experiment number

9.3 Glovebox number/lncal : :n

9.4 Experimenter's/Technician's name

9.5 Date procedure statts and finishes

9.6 Description of modification

(Drawings, sketches, etc., will) be kept in a separatc file crossreferenced t', the $\log$ book entry)

9.7 Weigits:

Parts

3crap

Loss

Cleaning materials

(If not weighable, calcula approximate weights)

9.8 Reč -ds parts, scrap, ecc., location (by cask/container)

9.9 Records all of the above data in paragraph 9 each ime material is processed through the Hot Gell 
Responsible Organization

Area V Control Division

(Control Coordinator)

(Experimenter)

Safeguards and Technical Security Division

(NM Manager)
Action

10. Returns materials in approved cask/ container to the appropriate location for final disposition.

11. Completes the final portion, "Notice of Modification/Expenditure of Nuclear Material", on the approved Form SA 6476-ME and forwards to the Nuclear Materials Manager, 3434.

12. Writes memorandum to DOE/ALO requesting authorization to remove from records any losses or expended material and disposition of scrap or excess material.

13. Prepares internal adjustment form (IAF) Form SA 6476-NF, from data returned on Form SA 6476-ME. 
19. Safety

Safety Engineering is responsible for the industrial safety portion of nuclear material storage and transport. The $\mathrm{Plant}$ Engineering Planning division is responsible for the fire safety aspects of nuclear materials.

Fissile materials and other radioactive material shall be packaged and prepared for shipment in manner that provides assurance of protection of the public health and safety during the transportation $c$ such materials.

Fissionable materials shall be processed, stored, transferred, ohandled in such a manner that the probability of fissionable material reaching accidental criticality is very low, and the protection of government and private personnel and public and private property against damaging effects and undue hazards that may arise from a criticality accident is assured.

The Sandia fire protection engineers in the P? ant Engineering Planning division should be consulted regarding the adequacy of facilities for nuclear materials operations.

- Consideratrion should be given to fire prevention, fire protection and fire fighting because of the possible consequences of a fire adjacent to nuclear materials.

- Ignition sources and fuel available should be reduced to the lowest practical level. Materials of the building construction should not introduce fuel sources and fire resistive construction should separate areas of unacceptable fuel loading from nuclear material operations.

- Consideration should be given to the installation of automatic fire alarm and suppression systems. Prefire planning should include familiarizing the fire response 
crews (fire department, brigade, and fire team) with radiological hazards.

Sandia Laboratories establishes and maintains an effective nuclear explosive safety program which will prevent nuclear explosives from producing a detonation (high explosive or nuclear) as the result of accidental or unauthorized actions. The program is coordinated and monitored by the Nuclear Safety Department, 1230 (at SLL, Systems Science Department, 8340). The organization controlling or performing operations involving a nuclear explosive is responsible for assuring nuclear explosive safety. In conjunction with the system Studies Division, 1231 (at SLL, Nuclear Safety Division, 8345), the concerned organization assures that all procedures and equipment are reviewed and approved prior to implementation.

For effective safety control of non-reactor SNM materials, Sandia Laboratories has established the Sandia Nuclear Criticality Safety Committee (at SLL, the SNCSC subcommittee) for the purpose of auditing Sandia's activities having nuclear criticality safety significance and advising the responsible management on such matter. The role of these committees does not reduce the direct responsibility for criticality safety delegated to Laboratories line management. 
CHAPTER $X$

COMPENDIUM OF RELEVANT NUCLEAR MATERIALS USER FORHS

Exhibit 1. Form SF 9211-F --- Program and Budget Proposal (DOE Schedule 189)

Fxhibit 2. Schedule DOE 189a -- Program and Budget Proposal, Nuclear Regulatory Research Program

Exhibit 3. Form DOE 408 -- Forecast of Nuclear Material Requirements

Exhibit 4. Form SA 6430-RD -- Purchase Requisition

Exhibit 5. Form SF 3004-C --- Authorization for Redelegation

Exhibit 6. Form SA 2042-D --- Nuclear and Radioactive Material Transfer

Exhibit 7. Form SF 6476-N -- Nuclear Material Custodian Inventory Status Card

Exhibit 8. Form SA 6505-WBA --- Process and Fabrication Request, Short/Sub Work Order

Exhibit 9. Form SA 6476-A -- Record of Assembly/Disassembly and Movement

Exhibit 10. Form SA 6476-NO -- Nuclear Materials Storage Justification

Exhibit 11. Form SF 6951-A --- Property Action (Shipper)

Exhibit 12. Form SA 6550-EA - Information for Hazardous Material shipments

Exhibit 13. Form RF-43940--- Authorization to Ship SS or Non-SS Material

Exhibit 14. Request For Foreign Contract Number and End Purpose Code Table

Exhibit 15. Form NRC-7 -- Application for License to Export Nuclear Material and Equipment

Exhibit 16. Form 7525-V -- Shipper's Export Declaration

Exhibit 17. Form SA 6476-ME -- Modification/Expenditure of Nuclear Materials

Exhibit 18. Form SA 6476-NG -- Transfer Request 
Form SF 9211-F --- Program and Budget Proposal (DOE Schedule 189)

Purpose: To define the scope of work and budget for a proposed program

Prepared by: Requesting Organization:

Submitted to: Budget and Management Information Department. Copy of this form should also be sent to the Safeguards and Technical Security Division.

Line Instructions: Appear on the back of the form. 


\section{Exhibit 1}

(1) Sandia Laboratories

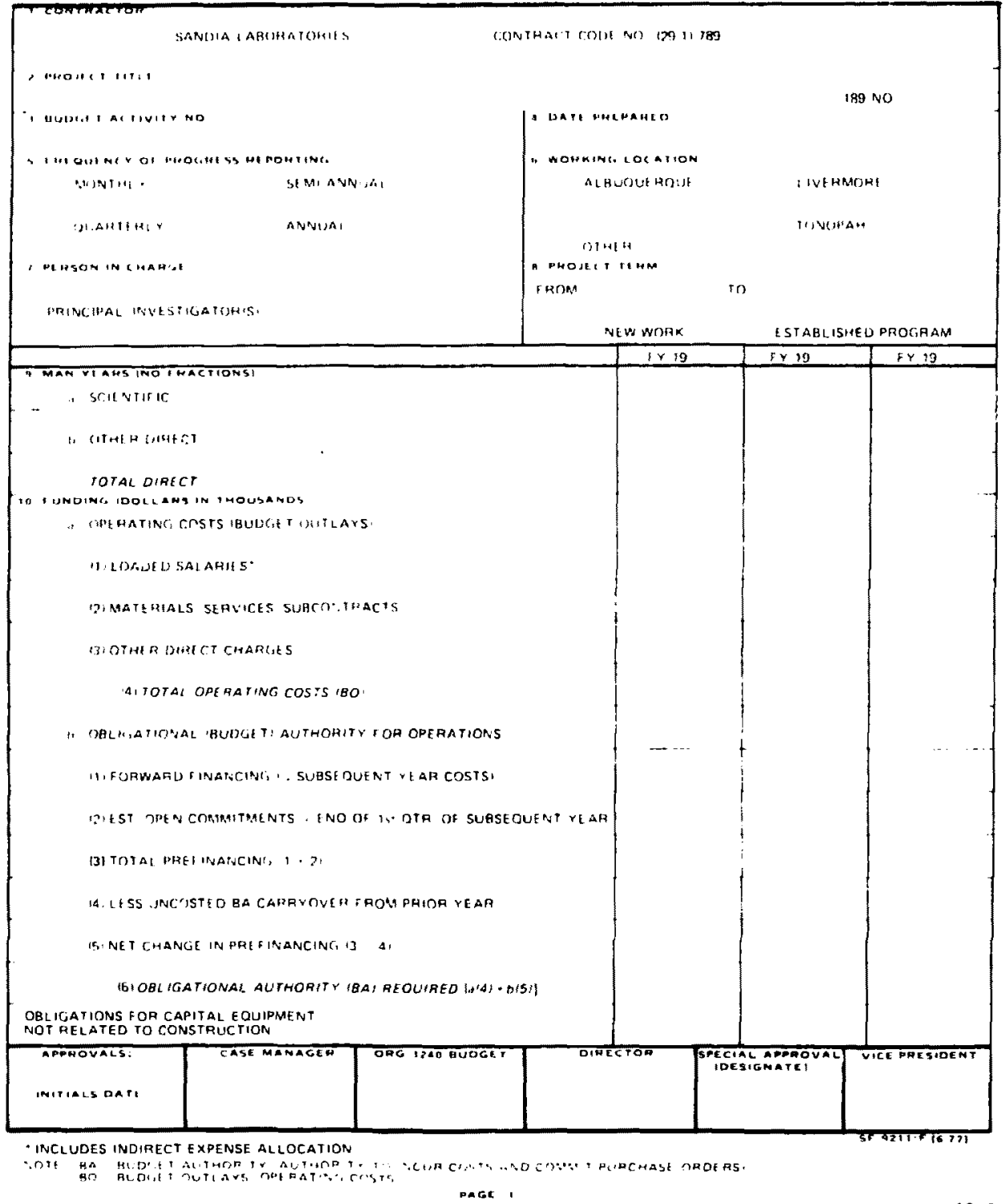


Instiuctions to pitenating Schetlule 189 iltem Nn.J

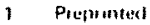

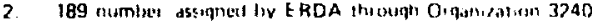

3 Bulget activity no. assignets ty ERDA through 3240

4 10 Self explanatory.

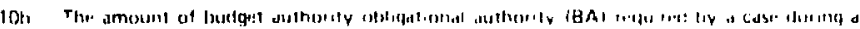

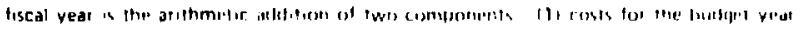

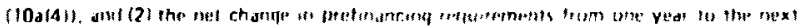

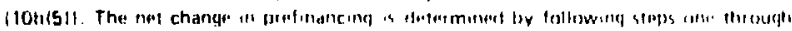
live under ifom ion

(U) contuujton shet fo: following items no 1320 )

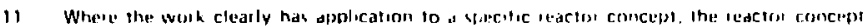

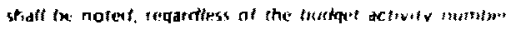

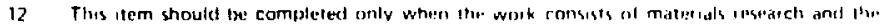
intormation should inclute the princionat material en atloy unrien investipation

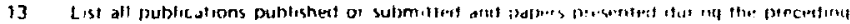

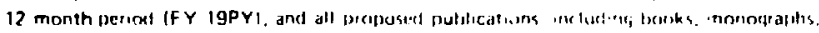

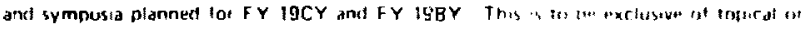
urogress reports submittert in ERDA

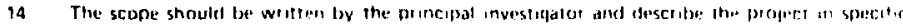

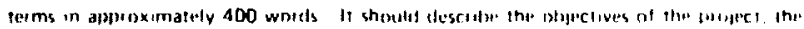
technical approach ant the applications of the andults

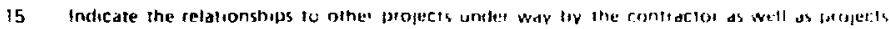
being contlucted by othets

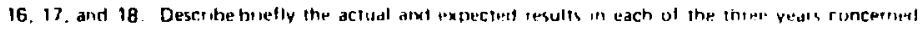

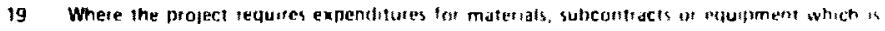
majot in cost a unusual in nature, such itums should ie described. the cust mstimal. quven ind an explanation of the reasons for ansl use's of sucti items sulomifiet

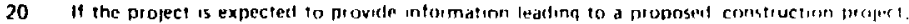
describst such project anil list the estimated dale's and amounis of funds lo be chlyaled

NOTE Use 189a tor Reactor Development Pionlam

Use 189c tor Wasie Management arid Waste Tianspor tation Prọ̣ı ams

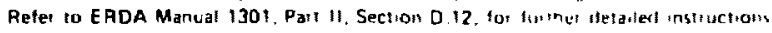


This page intentionally left blank.

$10-5$ 
Schedule DOE 189a --- Program and Budget Proposa1, Nuclear Regulatory Research Program

Purpose: To supplement DOE Schedule 189 with detailed macerial requirements.

Prepared by: Requesting organization.

Submitted to: Budget and Financial Planning Department. A copy of this form should a so be sent to the Safeguards and Technical Security Division.

Line Instructions: Refer to the line instructions on the back of DoE Schedule 189 (Form SF $9211-F$ ). 
Exhibit 2.

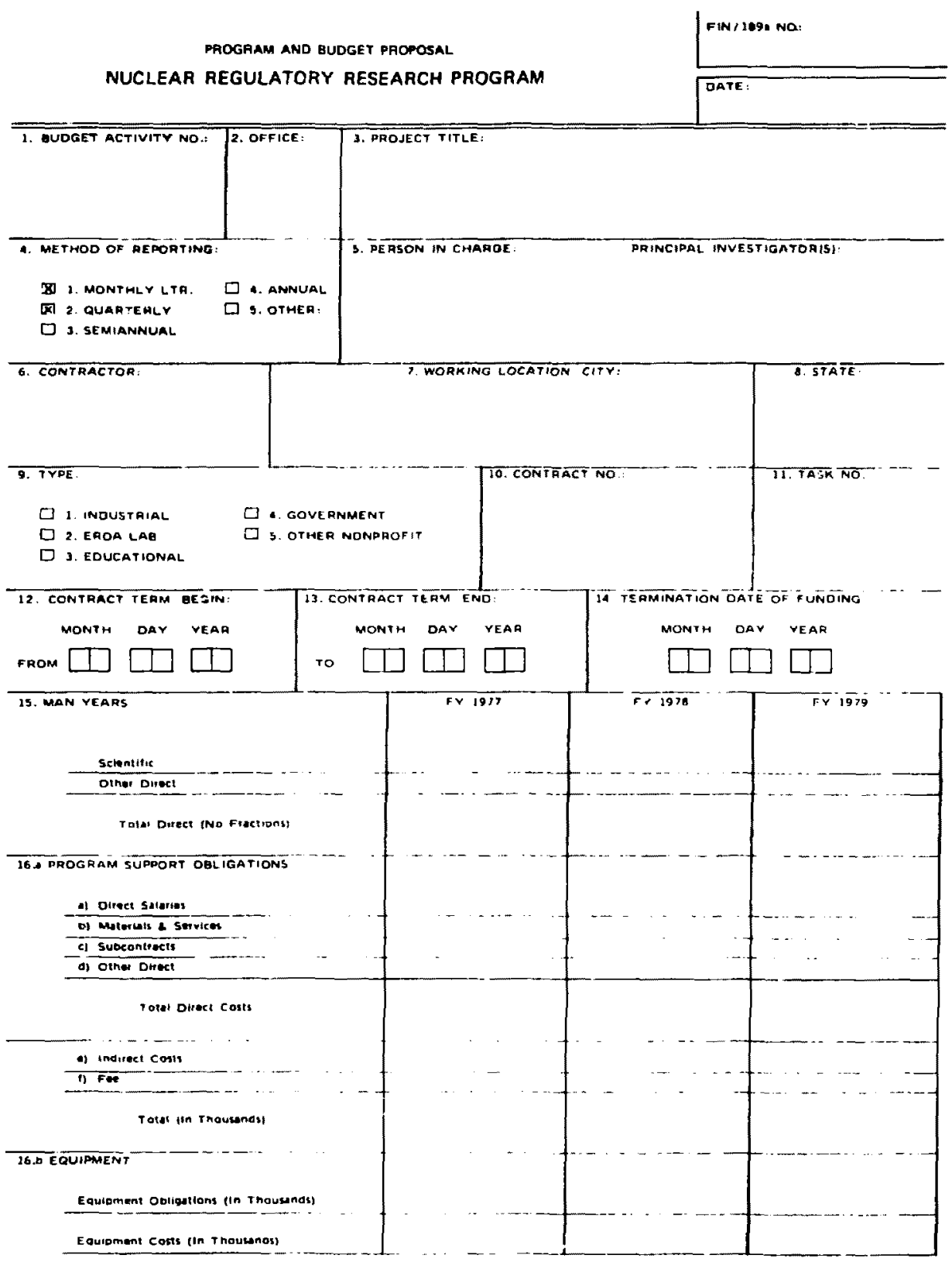


Form DOE 408 --- Forecast of Nuclear Material Requirements

\begin{abstract}
Purpose: To provide forecasts required by the DOE for selected nuclear matrials and boron-10. Materials to be forecast and the reporting units as follows:
\end{abstract}

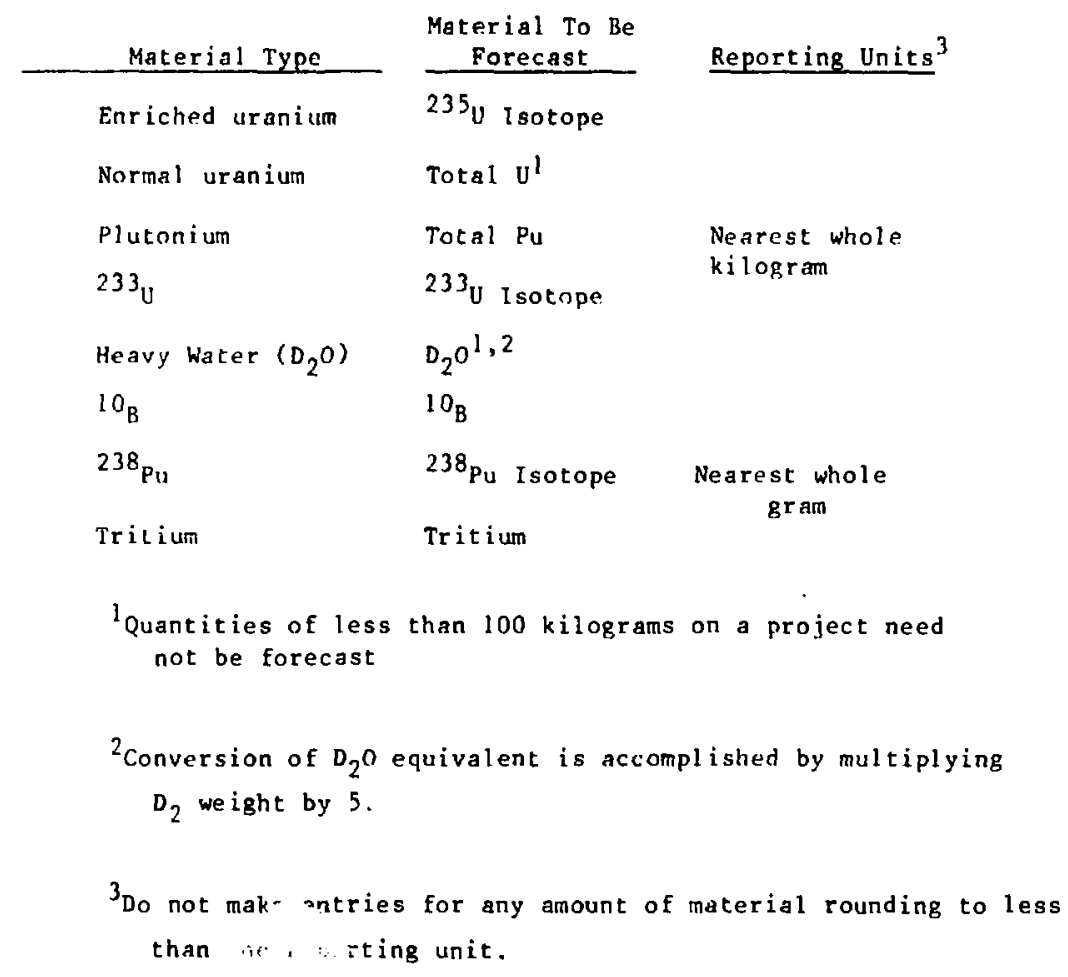

Prepared by: Director of using organization on or before December 1 of each year.

Submitted to: Nuclear Materials Manager, Sarieguards and Technical Security Division. 
Exhibit 3.

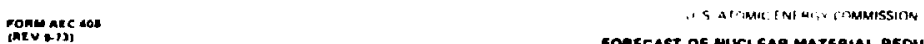
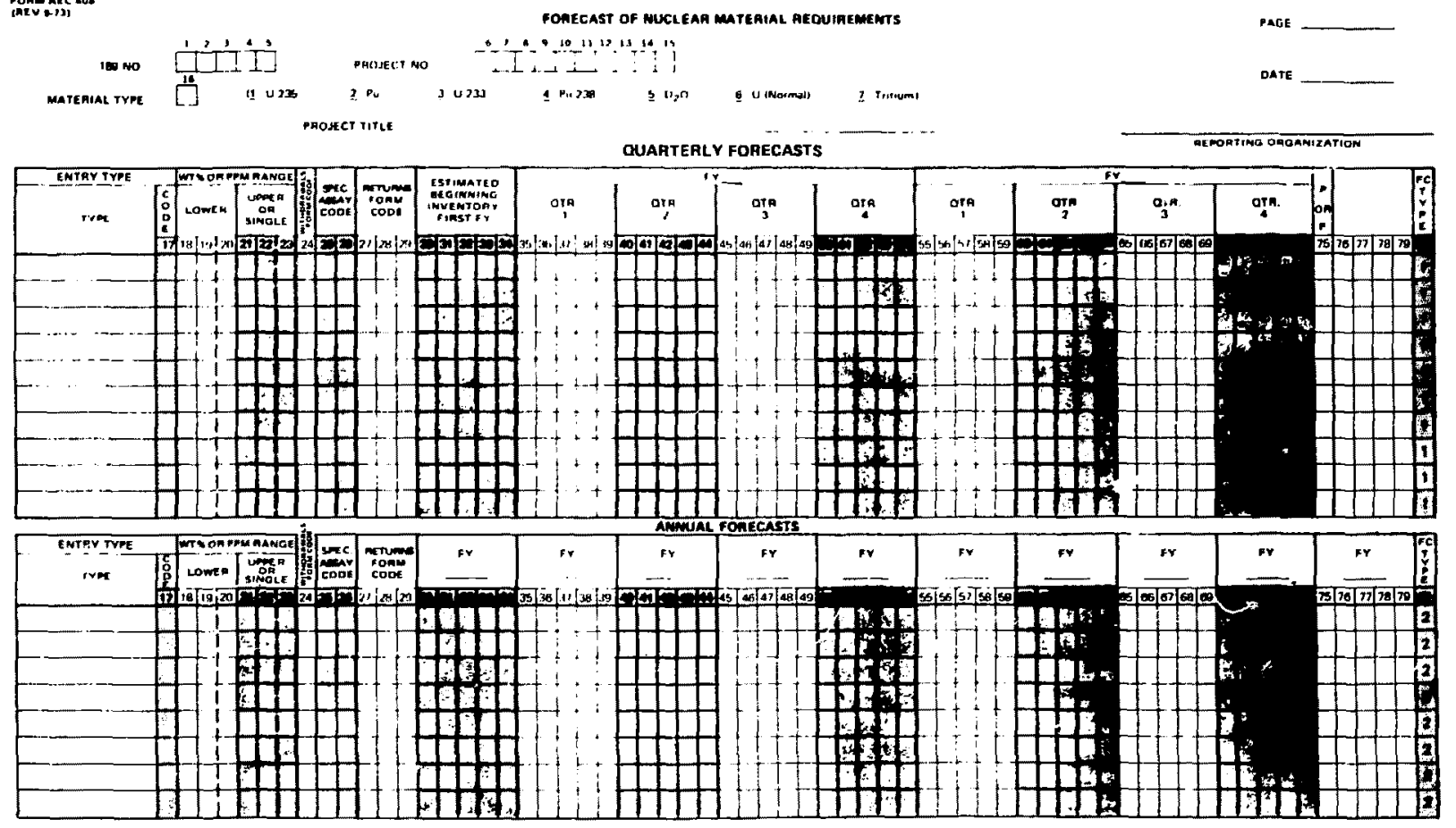
Line Instructions:

189 No.: Applies only ta Division of Reactor Research and Development projects for which Schedule 189a has been submitted to Headquarters.

Project No.: Furnished by the Nuclear Materials Manager.

Project Title: Furnished by the Nuclear Materials Manager.

Reporting Organization: Requesting organization.

Entry Type, Code:

\begin{tabular}{lc}
\multicolumn{1}{c}{ Type } & Code \\
\cline { 3 - 3 } Beginning Inventory & \\
Withdrawals & 2 \\
Unirradiated Returns & 3 \\
Irradiated Returns & 4 \\
Transfers In & 5 \\
Transfers Out & 6 \\
Burnup and Losses & 7 \\
Formation & 8 \\
Launch & 9 \\
Ending Inventory & 0
\end{tabular}

The following are the definitions of the entry types to be included in block 17:

Beginning inventory -- The estimated inventory assigned to the project number as of the first fiscal year in the forecast period. All quantities assigned to the project should be included in this inventory irrespective of location.

Withdrawals -- The movement of material from Production Program (-BXXXX-projects) to non-Production Program (non -BXXXX-projects) when looked at from the side of the receiver. Material to be obtained by DOE contractors under DOE lease agreements are considered to be withdrawals.

Returns - A transaction looked at from the side of the shipper which reflects the movement of material from non-Production Program (non -Bxxxprojects) to Production Progran (-BxXXX-projects). Includes processed scrap 
to be sent to Production Program by DOE contractors generating the scrap under DOE lease agreements.

Unirradiated returns -- Material which in its existing form has not been subjected to reactor irradiation.

Irradiated returns -- Material which in its existing form has been subjected to reactor irradiation.

Transfers in -- Material obtained for a project from another project but excludes material obtained as a result of "withdrawals". Includes materials obtained from other federal agencies, fureign countries, or private ownership. Aaterial obtained from another location without a change in project number is not considered to be a transfer in.

Material obtained by DOE from a licensee holding the material under a DOE lease agreement is a "transfer in" if the material was not obtained by the licensee for DOE contract work; if the material was obtained by the licensee for DOE contract work, the movement of material is not a transfer in.

Transfer out -- Material removed from one project and provided to another project but excludes materials moved as a result of "returns". Includes materials provided to other federal agencies, foreign countries, or co domestic companies for private use. Material sent to another location or another contractor without a change in project number is not a transfer out.

Burnup and losses -- Consists of processing losses, fabrication losses, test losses, discards, burials, losses due to recovery, irradiation, and decay, whether occurring at DOE operating contractors or under lease agreement where the material is held for DoE contract work.

Formation -- Material produced as a result of irradiation of other materials, e.g., U-233 or Pu produced in non-Production Program reactors.

Launch -- Macerial removed from inventory as a result of rocket launch into space, e.g., Pu-238 SNAP units. 
Ending inventory -- Inventory at the end of each fiscal year in total for project (irrespective of assay) calculated by adding receipts to the beginning inventory and suberacting all removals. For the first two fiscal years, enter the ending inventory in 4th quarter data field.

Weight Percent or PPM Range:

Enter assay for each entry type, except for the ending inventory (Code 0 ). With the exception of Entry Type Code O (Ending Inventory), assaya shall be entered for each type, i.e., beginning inventory, withdrawals, returns, etc., as follows:

\section{Material Reported}

U-235

$P_{u}$

U-233

Pu-238

Normal U

$\mathrm{D}_{2} \mathrm{O}$

Tritium
Arsay Data

Wt \% U-235 to nearest $0.1 \%$

Wt $\%$ Pu-240 to nearest $0.1 \%$

Ppm U-232 in uranium

Wt \% Pu-238 to nearest $0.1 \%$

Do not enter assay data

Do not enter assay data

Do not enter assay data

${ }^{1}$ Column 23 does not indicate tenths when assay is in parts per million (ppm) U-232; therefore, last digit of ppm should appear in column 23.

Single assays shall be shown in blocks (21-23). Ranges of assays may be shown by using blocks (18-20) for the lower assay and blocks (21-23) for the upper assay. Ranges of assays should be avoided unless absolutely necessary. In particular, they should be avoided to describe beginning inventories (Entry Type Code 1). Use of assay ranges for withdrawals during the first two fiscal years will be interpreted as meaning that any material within the indicated assay range is acceptable. Weight percent should be shown for entries identified as burnup and losses (Entry Type Code 7). For material consumed in a reactor, enter the weight percent of the material loaded into the reactor prior to irradiation. Assays should be right adjusted, i.e., entries start at 
right and work left. A range of 5 to 50 ppm U-232, for example, would be shown as:

Withdrawals Form Code:

$\begin{array}{ll}\text { Code } & \text { Form } \\ 1 & \text { Hexafluoride } \\ 2 & \text { Nitrate } \\ 3 & \text { Metal } \\ 4 & \text { Dioxide } \\ 5 & \text { Other }\end{array}$

Spec. Assay Code:

To be entered for irradiated U-235 returns, Pu withdrawals and returns, and $\mathrm{D}_{2} \mathrm{O}$ withdrawals and returns as follows:

\begin{tabular}{ll} 
Irradiated $U-235$ \\
Code $\%$ U-236 \\
\hline $\begin{array}{l}11 \\
02\end{array} \quad 1<1$ \\
03 & $2<2$ \\
04 & $3<4$ \\
05 & $4<5$ \\
06 & $5<6$ \\
07 & $6<7$ \\
08 & $7<8$ \\
09 & $8<9$ \\
10 & $9<10$ \\
11 & $10<11$ \\
12 & $11<12$ \\
13 & $12<13$ \\
14 & $13<14$ \\
15 & $14 \delta$ above
\end{tabular}

Pu withdrawals and Returns Code \% Pu-241 \% Pu-238

$20<1<.05$
$21 \quad 1<2<.05$

$\begin{array}{llrr}\text { Code } & \% P u-241 & \% & \text { Pu-238 } \\ 22 & 2<3 & <.05 \\ 23 & 3<4 & <.05 \\ 24 & 4<5 & <.05 \\ 25 & 5<10 & <.05 \\ 26 & 10<15 & <.05 \\ 27 & 15 \& \text { above } & <.15 \\ 28 & & <1 & .05-.10 \\ 29 & 1<2 & .05-.10 \\ 30 & 2<3 & .05-.10 \\ 31 & 3<4 & .05-.10 \\ 32 & 4<5 & .05-.10 \\ 33 & 5<10 & .05-.10 \\ 34 & 10<15 & .05-.10 \\ 35 & 15 \& \text { above } & .05-.10 \\ 36 & 1<1 & >.10 \\ 37 & 1<2 & >.10 \\ 38 & 2<3 & >.10 \\ 39 & 3<4 & >.10 \\ 40 & 4<5 & >.10 \\ 41 & 5<10 & >.10 \\ 42 & 10<15 & >10 \\ 43 & 15 \& \text { above } & >.10\end{array}$

$\mathrm{D}_{2} \mathrm{O}$ Withdrawals and Returns

Code $\quad \mu \mathrm{Ci}$ Tritium/ml

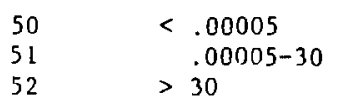




\section{Returns Form Code:}

For returns of irradiated and unirradiated U-235, normal uranium, PU, U233, and $\mathrm{Pu}-23 \mathrm{~B}$, enter the three-character classification code established by American National standards Institute (ANST) to designate majo: grade and subgrade. (Although the ANSI codes were established for unirradiated scrap, in this instance, they should be applied to irradiated materials also.)

\section{Estimated Beginning Inventory First FY:}

On the line reflecting beginning inventory (Entry Code 1), enter the estimated inventory for the project, regardless of location, as of the first day of the first fiscal year to which the forecast applies. Include material being processed or fabricated for the project which is held under Lease Agreements. Judgment should be used so that materials of only slight differences in assay, say with one percent U-235, Pu-240, or Pu-238, may be combined and reported as a single quantity with a single assay rather than a range. All entries of quantities shall be right-adjusted.

Remaining forecasts (Qtr. 1, Qtr. 2, etc.) are to be entered similarily. Enter appropriate quantities for each entry type (with the exception of beginning inventories which are entered in blocks 30-34) for each quarter for the first two fiscal years and annually for the remaining 10 fiscal years. In the blank next to "FY" insert the twa-character number reflecting the appropriate fiscal year, e.g., 75, 76, 77, etc. Twelve entries should be made to reflect consecutive fiscal years of the forecast period. All entries of quantities shall be right-adjusted.

P or F:

Enter P (probable - probability 50\%) or F (firm) to indicate the degree of probability of the forecast for withdrawals or returns only.

Column 76:

For "transfers in" (Code 5) and "transfers out" (Code 6) only, enter "1" if the transfer is to occur within the allotment, or "2" if the transfer is to occur between two different allotments. 
Columns 77-79:

No entries are to be made in these blocks for quarterly forecasts.

NOTE:

The original of materials identif destination of materials identified as "transfers out" should be noted at the bottom of the back of each applicable page. For materials identified as "transfers in," show the project number from which the material is to he obtained. For "transfers out," show the project number to which the material will be provided. 
Form SA 6430-RD --- Purchase Requisition

Purpose: $\quad$ To procure radioactive and nuclear materials.

Prepared by: Requesting organization.

Submitted to: Safeguards and Technical Security Division for special approval. This form must include the total amount of accountable material required (which must also have been forecast), as well as the disposal procedures for scrap generated during processing.

Line Instructions: Appear on the back of the form. 
Exhibit 4.

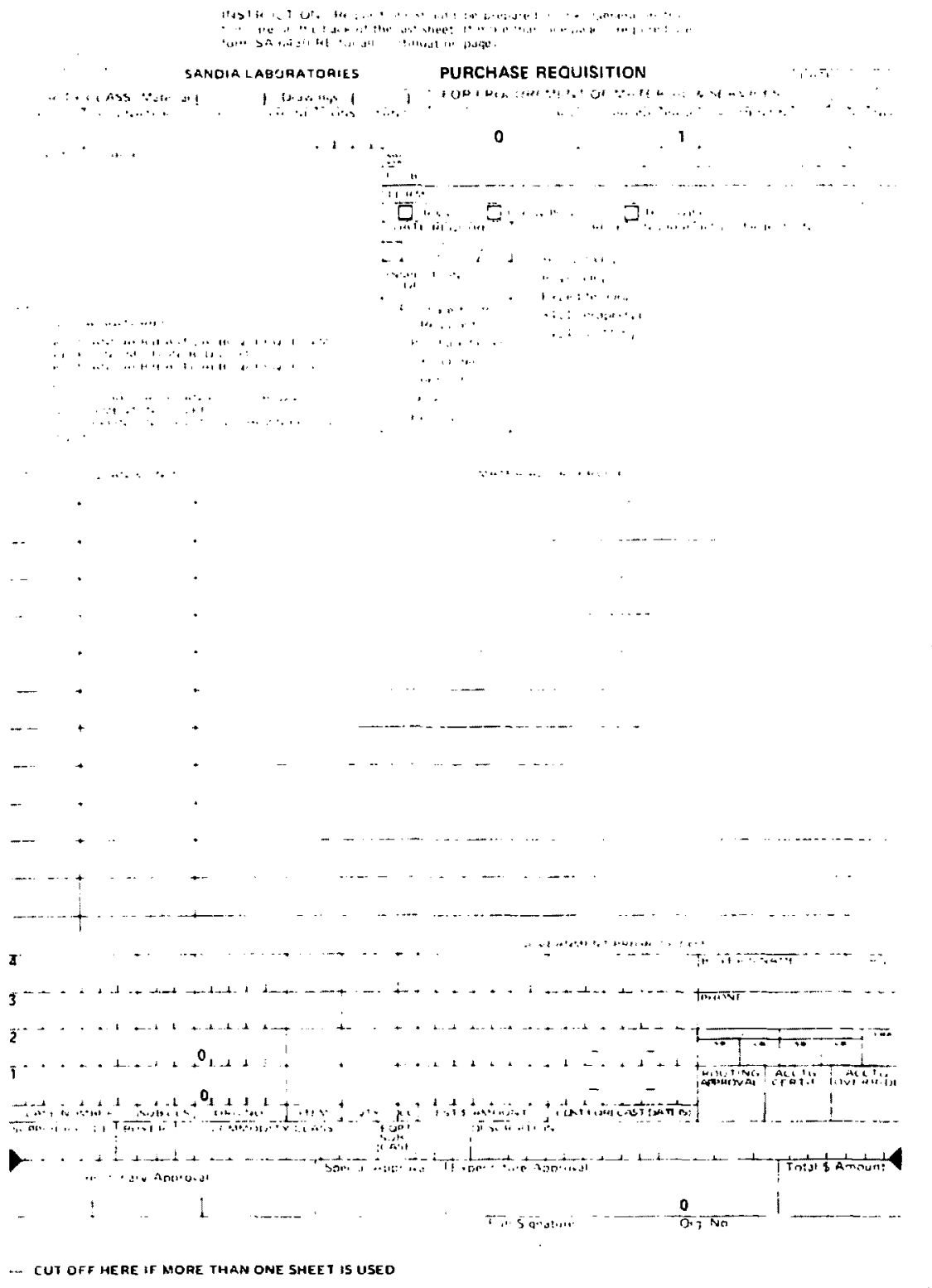




\section{INSTRUCTIONS FOR PREPARATION OF PURCHASE REQUISITION}

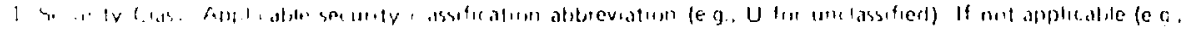

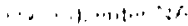

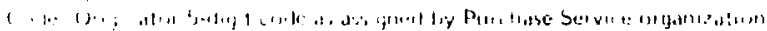

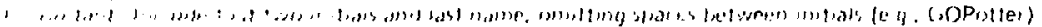

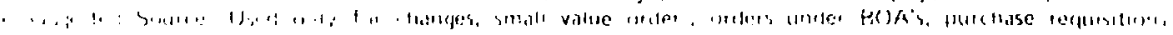

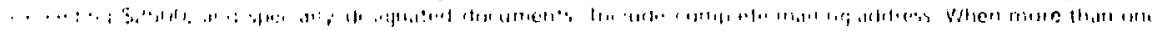

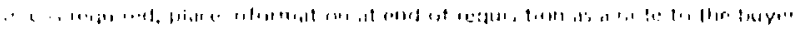

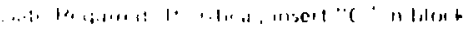

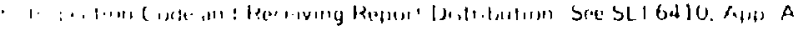

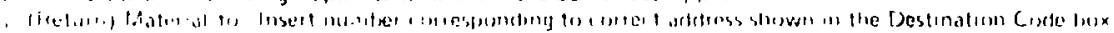

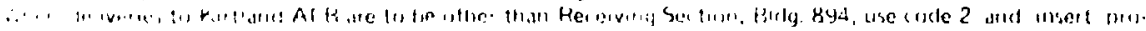

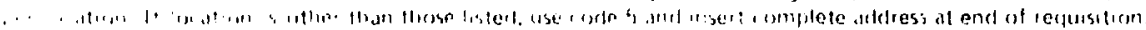

.... :

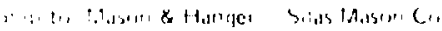

Panto. Pant

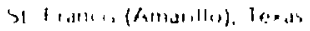

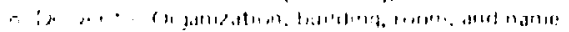

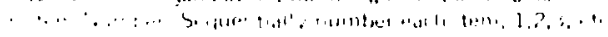

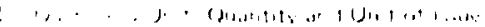

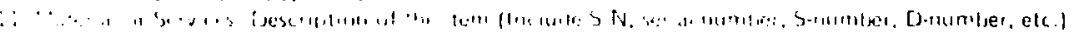

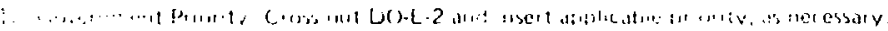

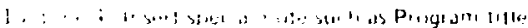

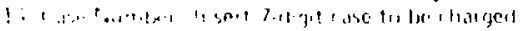

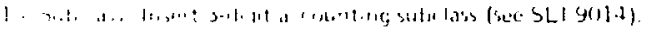

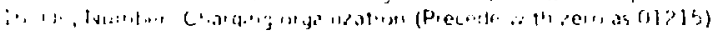

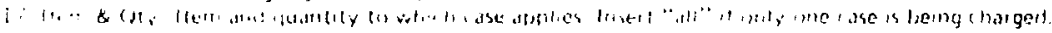

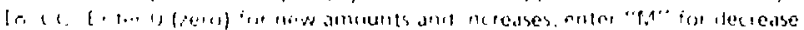

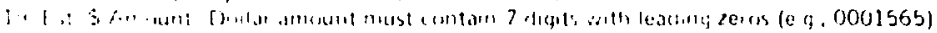

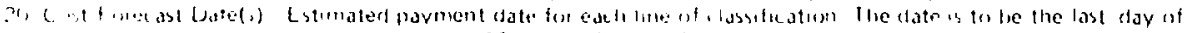

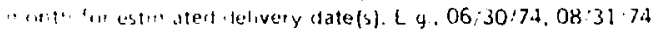

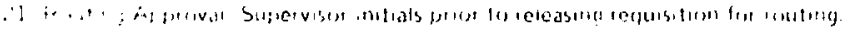

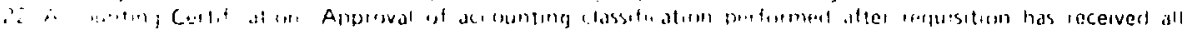

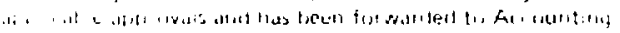

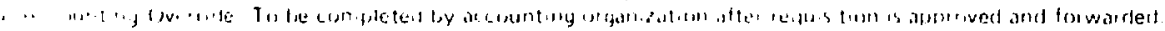

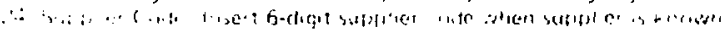

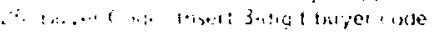

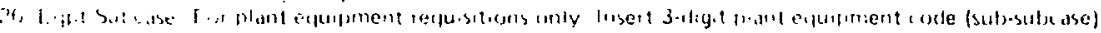

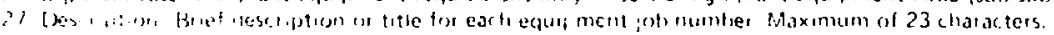

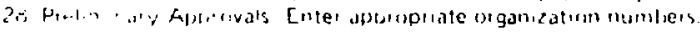

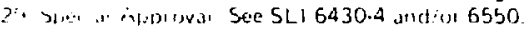

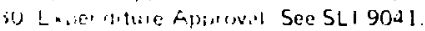

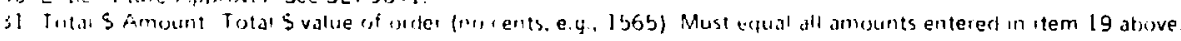

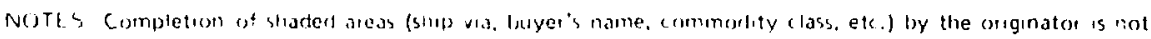
retiunet.

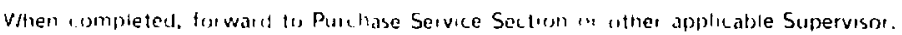


This page intentionally left blank. 


\title{
Form SF 3004-C --- Authorization for Redelegtion
}

\author{
Purpose: To designate a custodian and alternate custodian to control and \\ inventory materials within a material bal.tnce area. \\ Prepared by: Designated custodian/alternate custodian. \\ Submitted to: Safeguards and Technical Security Division. \\ Line Instruc:ions:
}

Nature of Authority: Nuclear Materials Custodian/

Alternate Custodian.

Limit: Not required

Approval for Pedelegation: Director's signature.

Signature Accepted: To be signed by Nuclear

Materials Representative, Safeguards and Technical

Security Division. 
r.xhibit 5

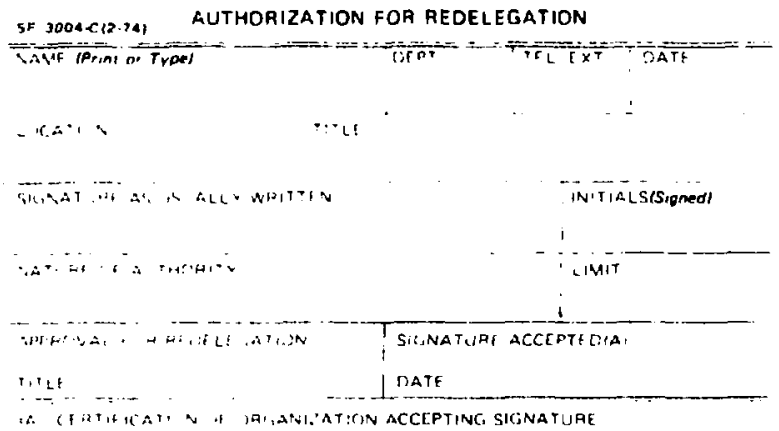


Form SA2042-D --- Nuclear and Radinar:ive Material Transfer

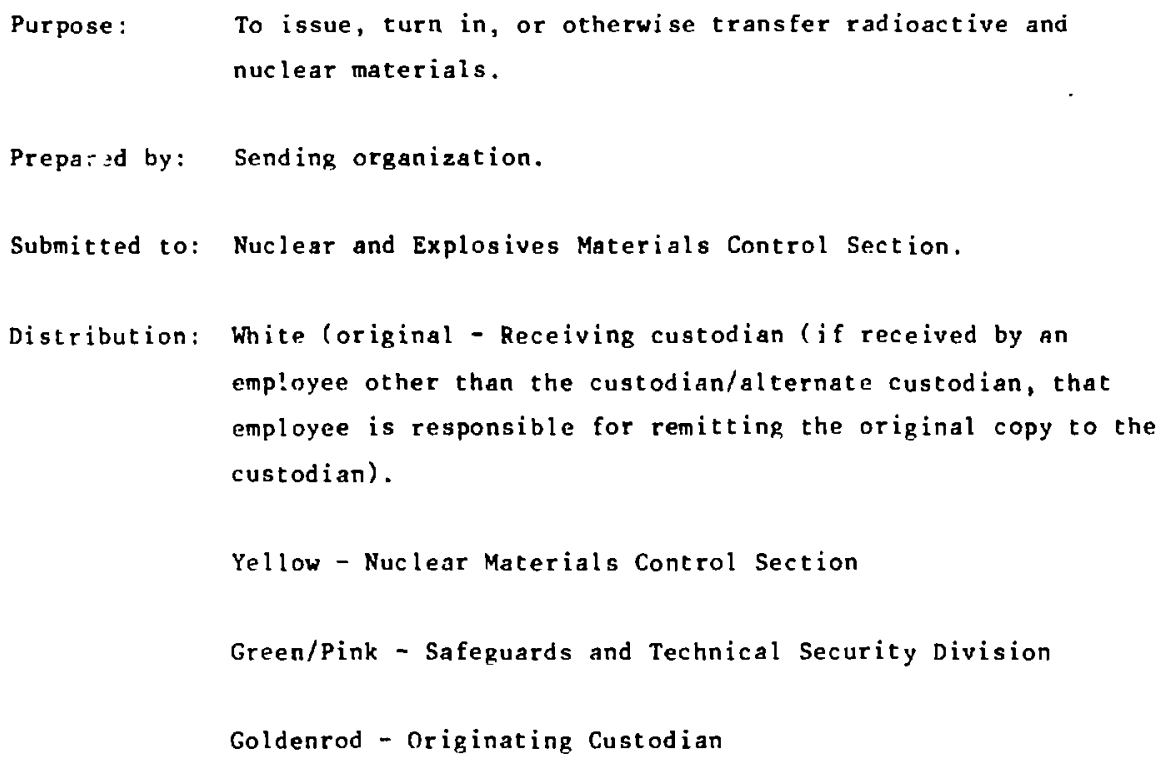


lixhihit 1 .

"a noe, a... NUCLEAR AND RADHOACTIVE MATERIAL

No 05450

TRANSFER

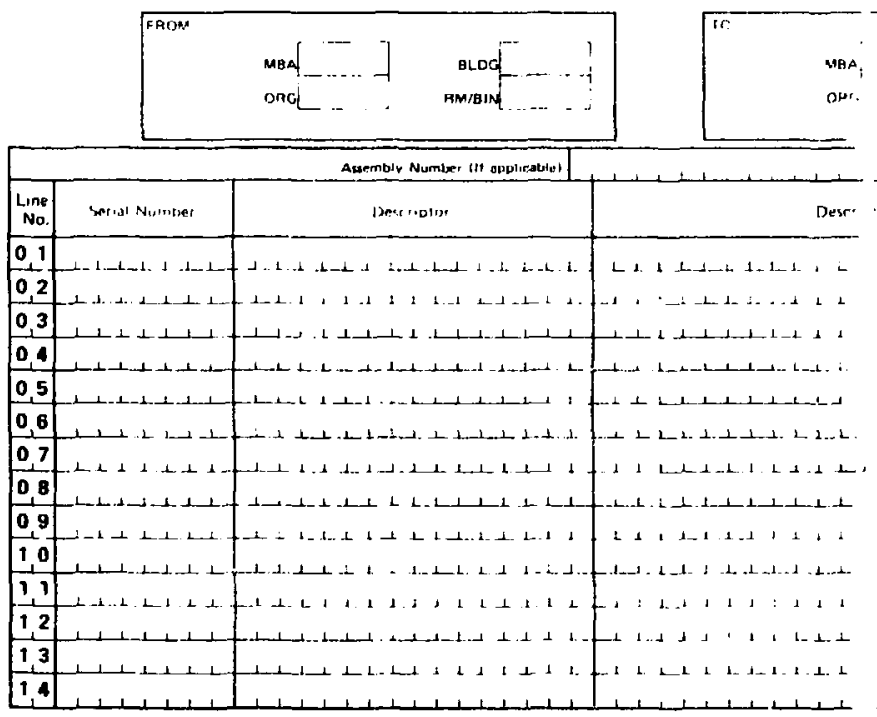

Remarks.

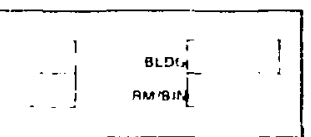

$\operatorname{mec} u$

Storise

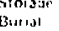

M.ir hinstit

Snipung
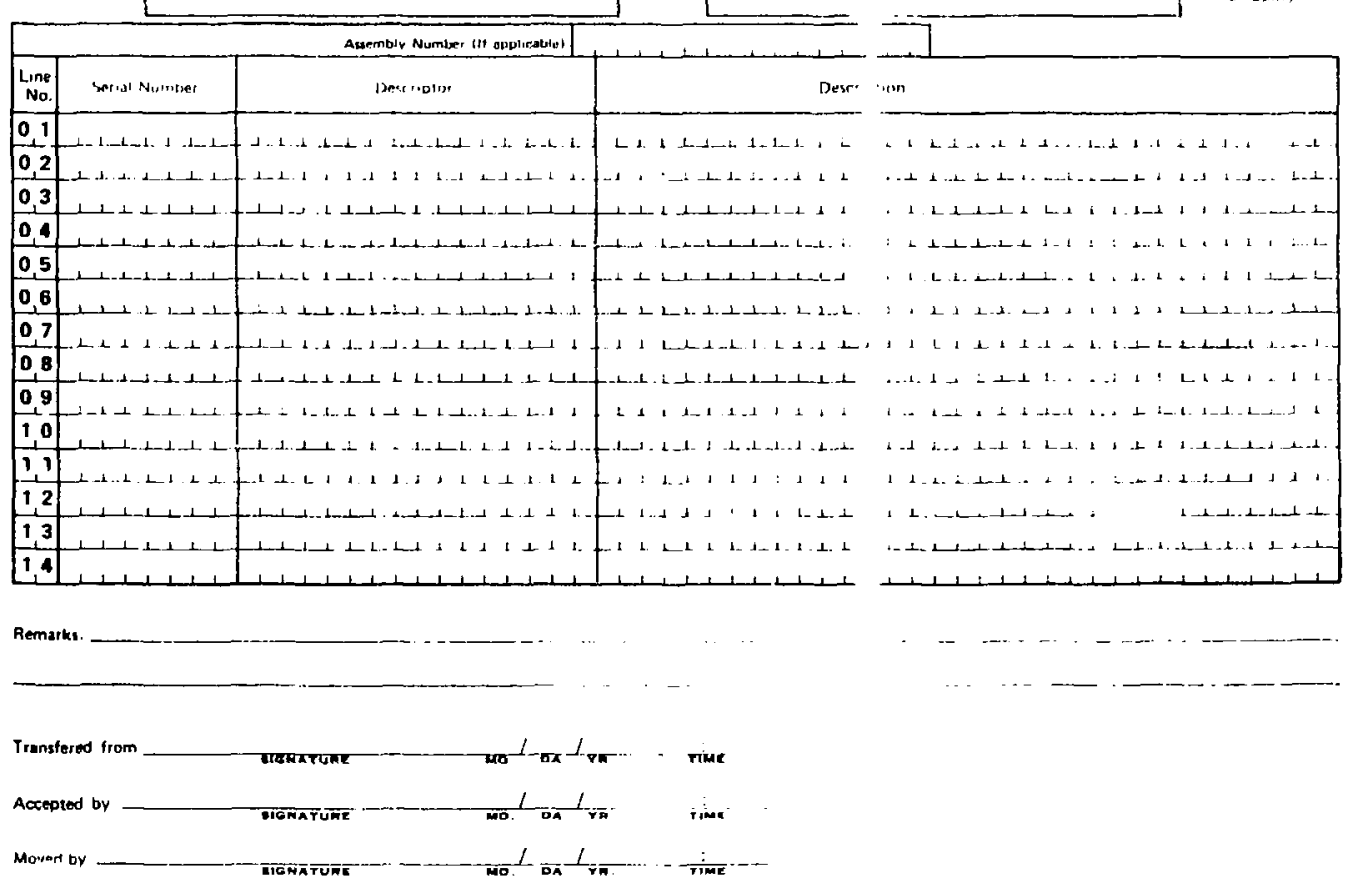

OISTRIGUTION: WhITE - RECEIVI 


\section{Form SF 6476-N -- Nuclear Material Custodian Inventory Status Card}

Purpose: To control material within a material balance area.

Prepared by: Custodian.

Comment: Use of this form by the custodian is optional.

Submitted to: Maintained by custodian as a record of accountable material. 
Sxhinit 7

\section{NUCLEAR MATERIAL CUSTODIAN INVENTORY STATUS CARD}

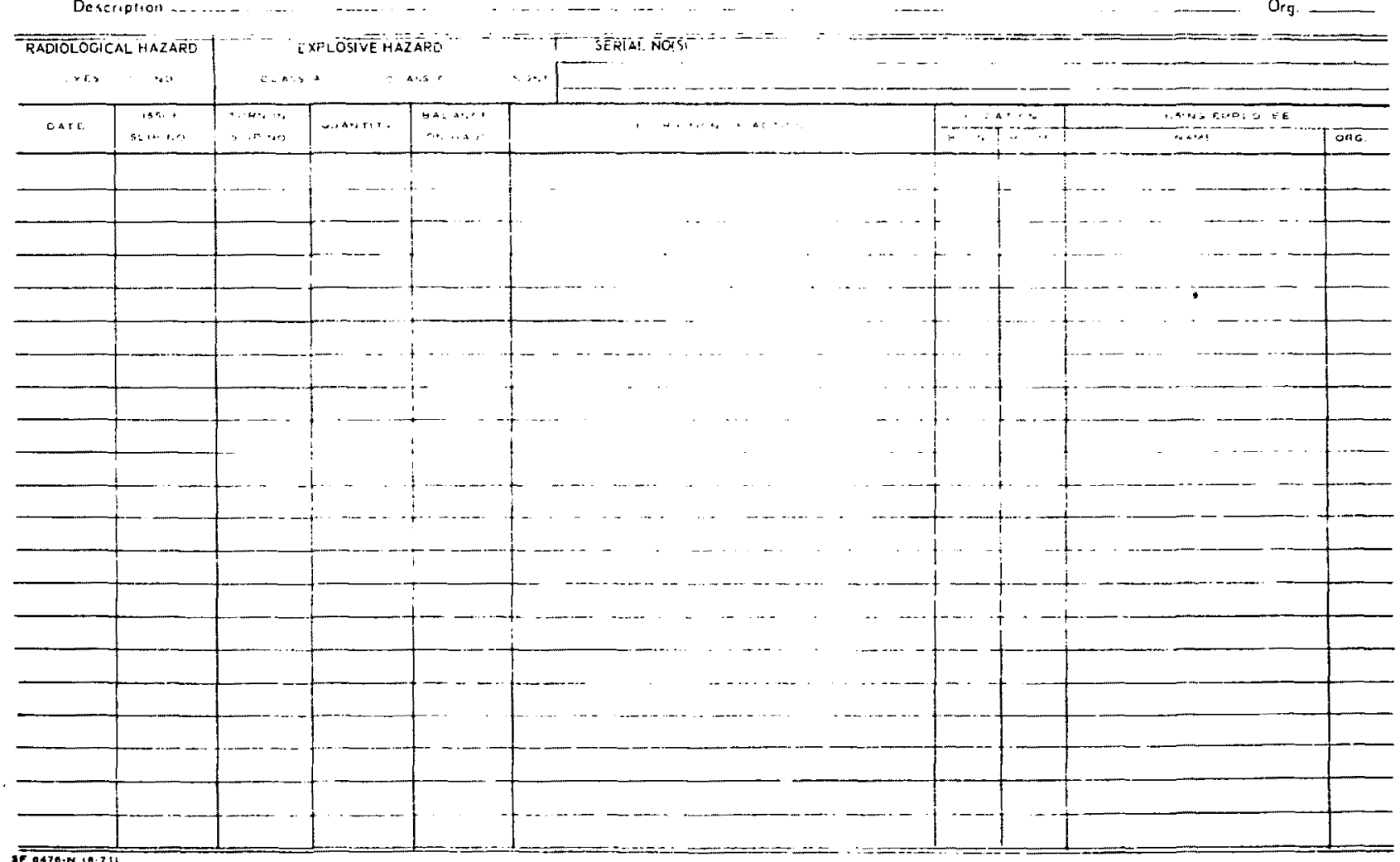


Form SA 6505-WBA --- Process and Fabrication Request, Short/Sub Work Order

Purpose: To provide specifications for machining of depleted uranium.

Prepared by: Requesting organization.

Submitted to: Mechanical Processing Department (Toxic Shop). 
Exhibit 8.

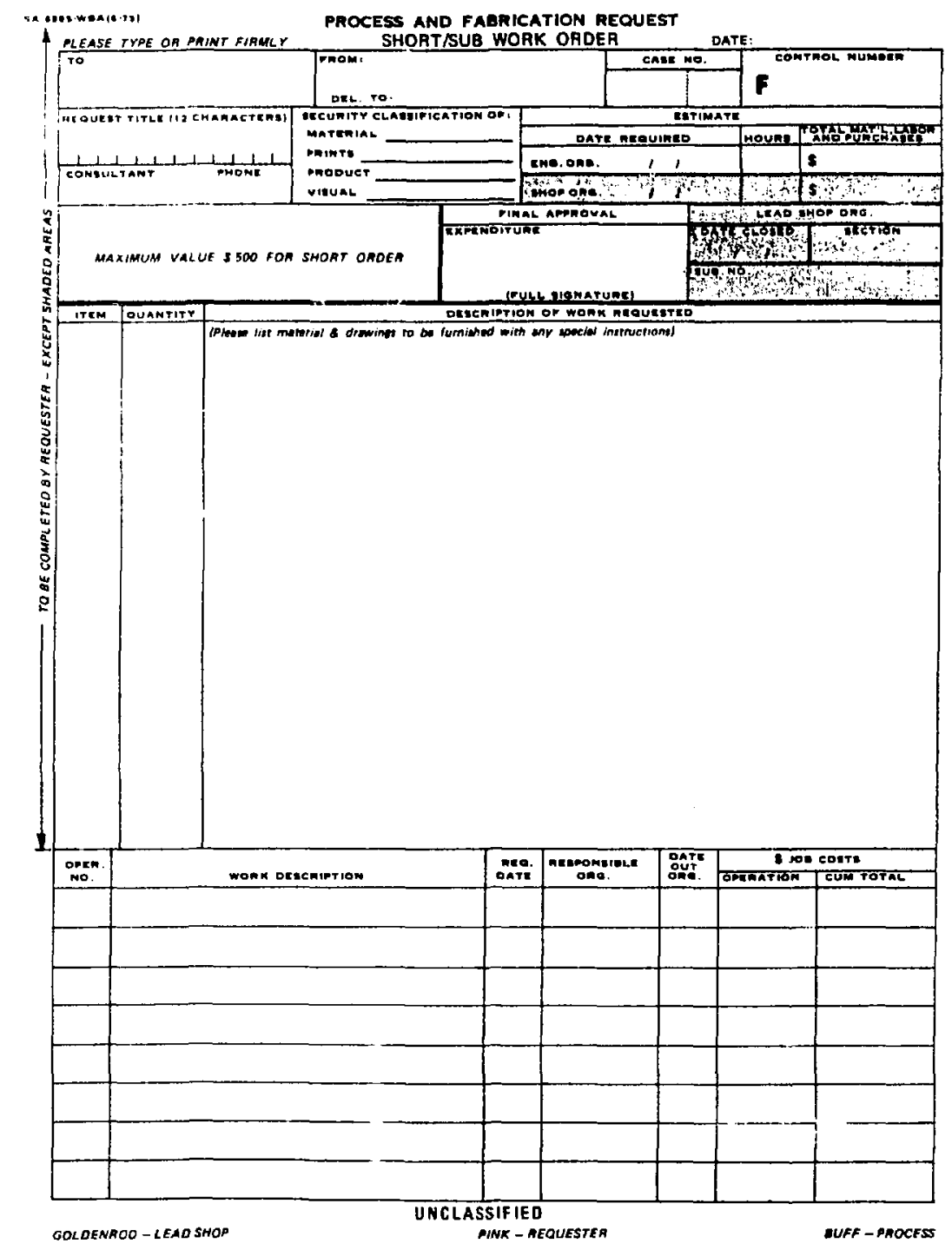


Form SA 6476-A -- Record of Assembly/Disassembly and Movement

Purpose: $\quad$ To document tranactions in which parts comprised of or containing SS material are assembled, in which assemblies containing ss material are disassembled, or in which assemblies are being shipped.

Prepared by: Using organization personnel (and signed by the division supervisor)

Submitted to: Safeguards and Technical Security Division (to update the computer master file).

NOTE: Originator is also responsible for supplying a completed copy of this form to the accountable custodian in order to update material balance area records.

\section{Line Instructions:}

Computer Reference: 741 Reference as stated on transfer document (Form SA 2042-D).

Comment :

This Eorm must accompany the shipper (Form SF 6951-A whenever assemblies are being shipped 
Exhibit 9 .

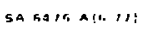

DATE SUBMITTED:

RECORD OF ASSEMBLY/DISASSEMBLY AND MOVEMENT

TO. NUCLEAR MATERIALS MANAGEMFNT SECTION - 3414/BLDG. 892

NUCLF AF MATE!IA! IN MY CUSTODY HAS BEEN ASSEMBLED OR DISASSEMBLED AS IOLLIJWS.

A. ASSEMBLY

1 ASSFMEL Y NUMBEF AN'D UNIT DESCRIPTION

2. SFRIAL NIJMBELS: OF CCNTMINFD WLCLEAR MATLHIAL. IAPTS

IJESCRIPTION

COMPUTER

REFERENCE

(EXAMPLE: AUA 00017002 )

?. DISAGSEMGLY

1. GiSSF"H: :D FR.1\% (AS.3 Y NUR.TBL R AND UNIT DESCRIPTIOIN)

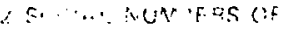

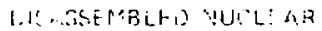

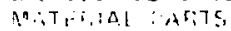

I SSRRITIUIN

3. COMPUTER REFERENCE OF ASS'Y

- NUCLEAT MATERTALS RESPONSIRLE DINTBON SUTERVIJOA

c. MOVEMIENT

1. TH:S MATERIAL WILL BE MOVED FROM _... _....... TO

2. DEPARTURE DATE

3. RETURN DATE

4. REMARKS.

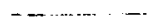


Form SA 6476-ND -- Nuclear Materials Storage Justification

Purpose: Owner MBA justification for material transferred to storage.

Prepared by: Owner MBA division supervisor requesting storage.

Approved by: Owner MBA division supervisor, department manager, or director, depending upon the length of storage.

Submitted to: Nuclear and Explosives Materials Control Section supervisor. 
Exhibit 10

Date

NUCLEAR MATERIALS STORAGE JUSTIFICATION

MBA $\square$ ORG. Responsible Division Supervisor

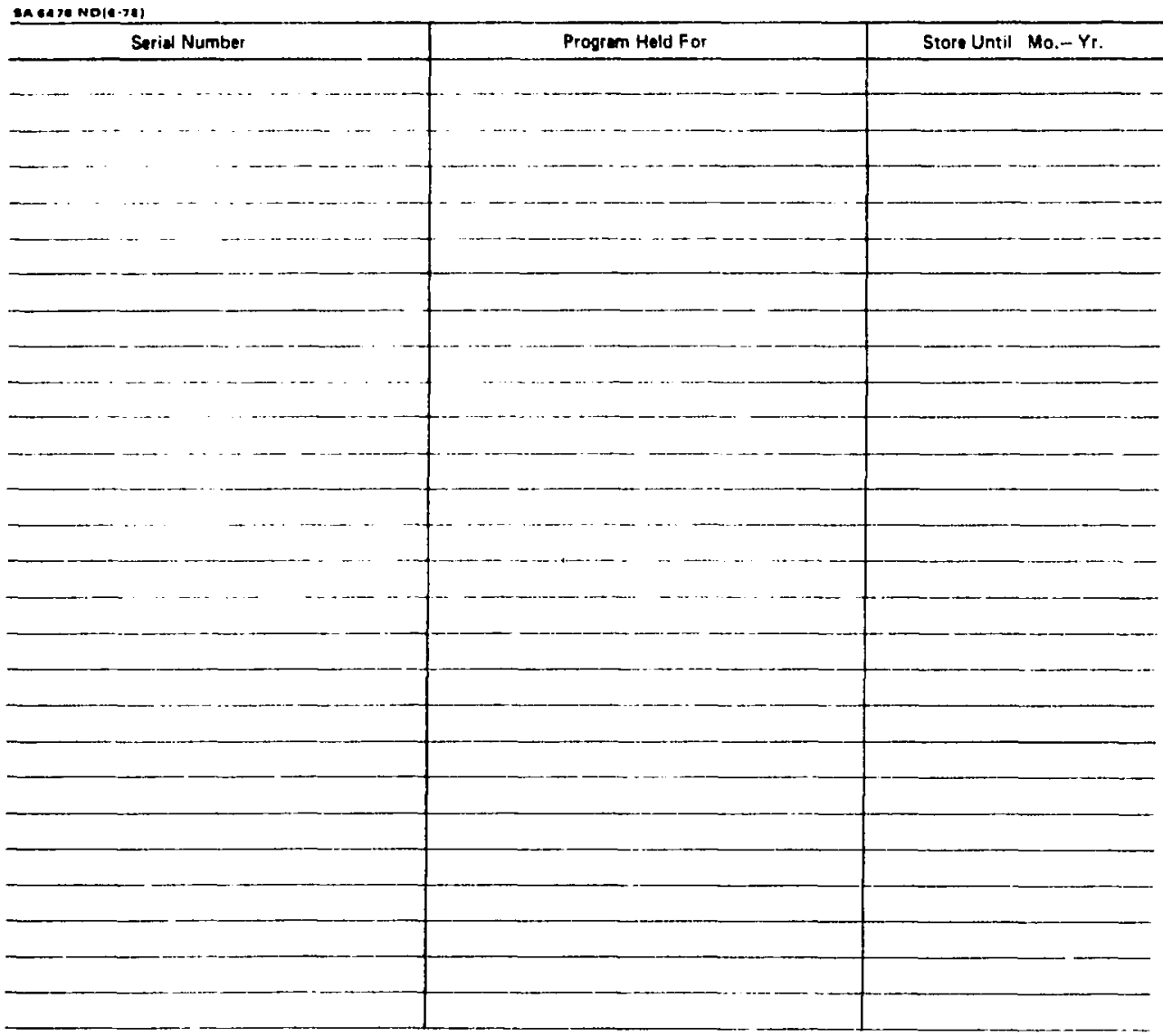

Approved by 


\section{Form SF 6951-A --- Property Action (Shipper)}

Purpose: To ship radioactive and nuclear materials.

Prepared by: Requesting organization.

Submitted to: Nuclear and Explosives Materials Control Section.

This form, along with "Information for Hazardous Material

Shipments" (Form SA 6550-EA) and, when assemblies are shipped,

"Record of Assembly/Disassembly and Movement" (Form SA 6476-A), must accompany all materials transferred to the Nuclear

Material Section, Building 867 south, for shipment.

Distribution: Indicated on individual copies of form.

Line Instructions: Appear on the back of the form. 
Exhibit 11.

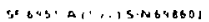

SANDIA LABORATORIES

PROPERTY ACTION ALBUOUERQUE, N.M. B7115

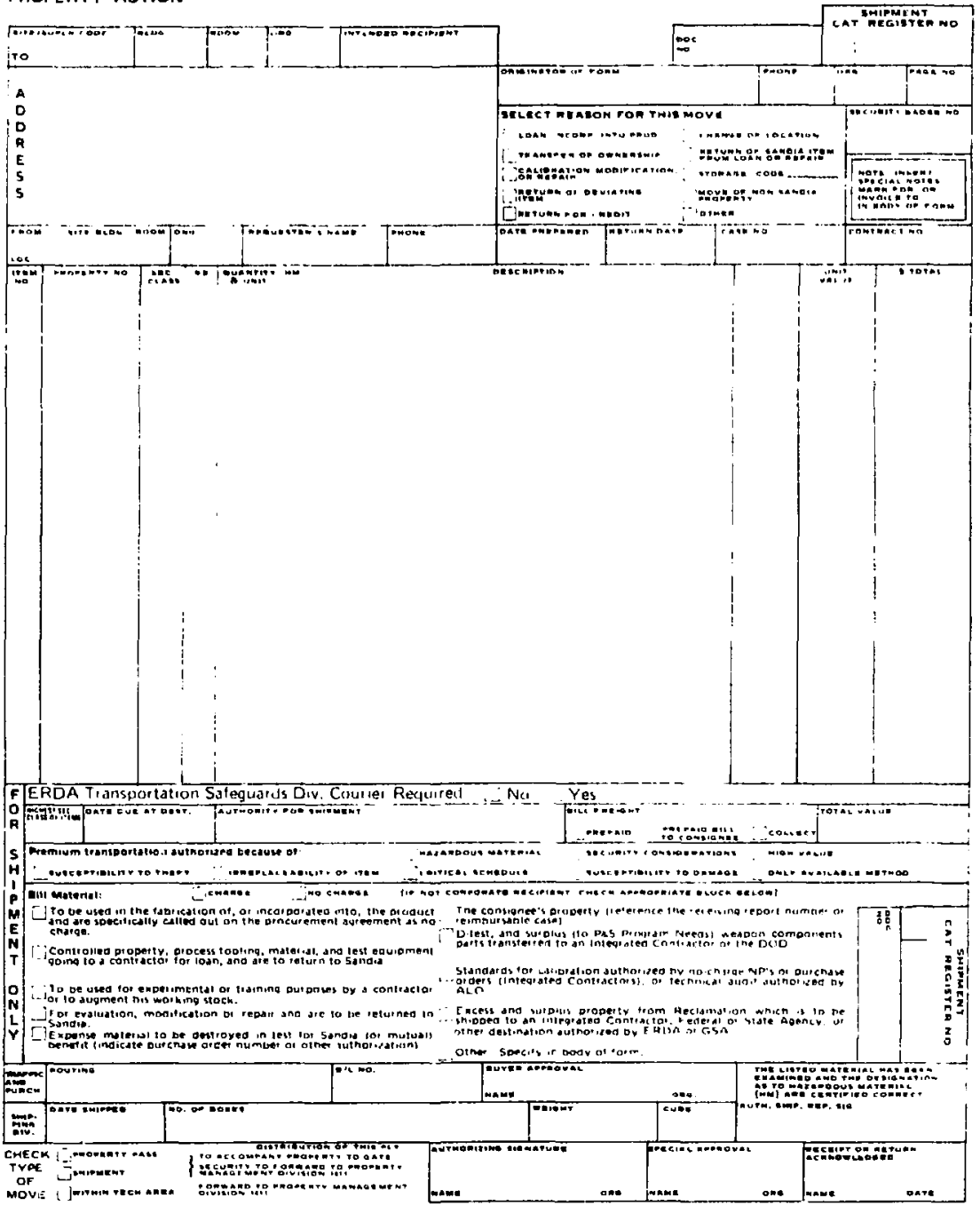

GATE PASS । 
INSTAUCTIONS FOR PAEPARATION OF PROPFATY ACTION FORM (PAF)

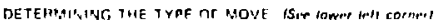

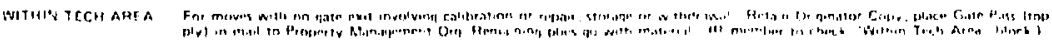

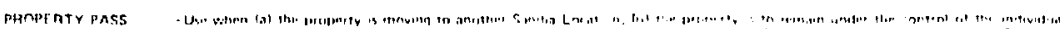

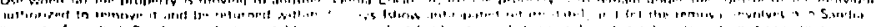

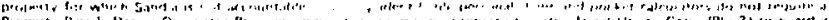

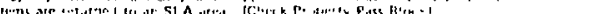

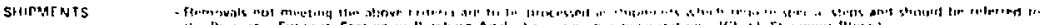
Silcial. Writs

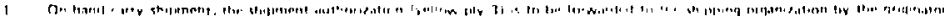

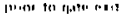

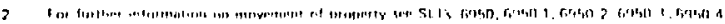

3. $\mathrm{A}$, :

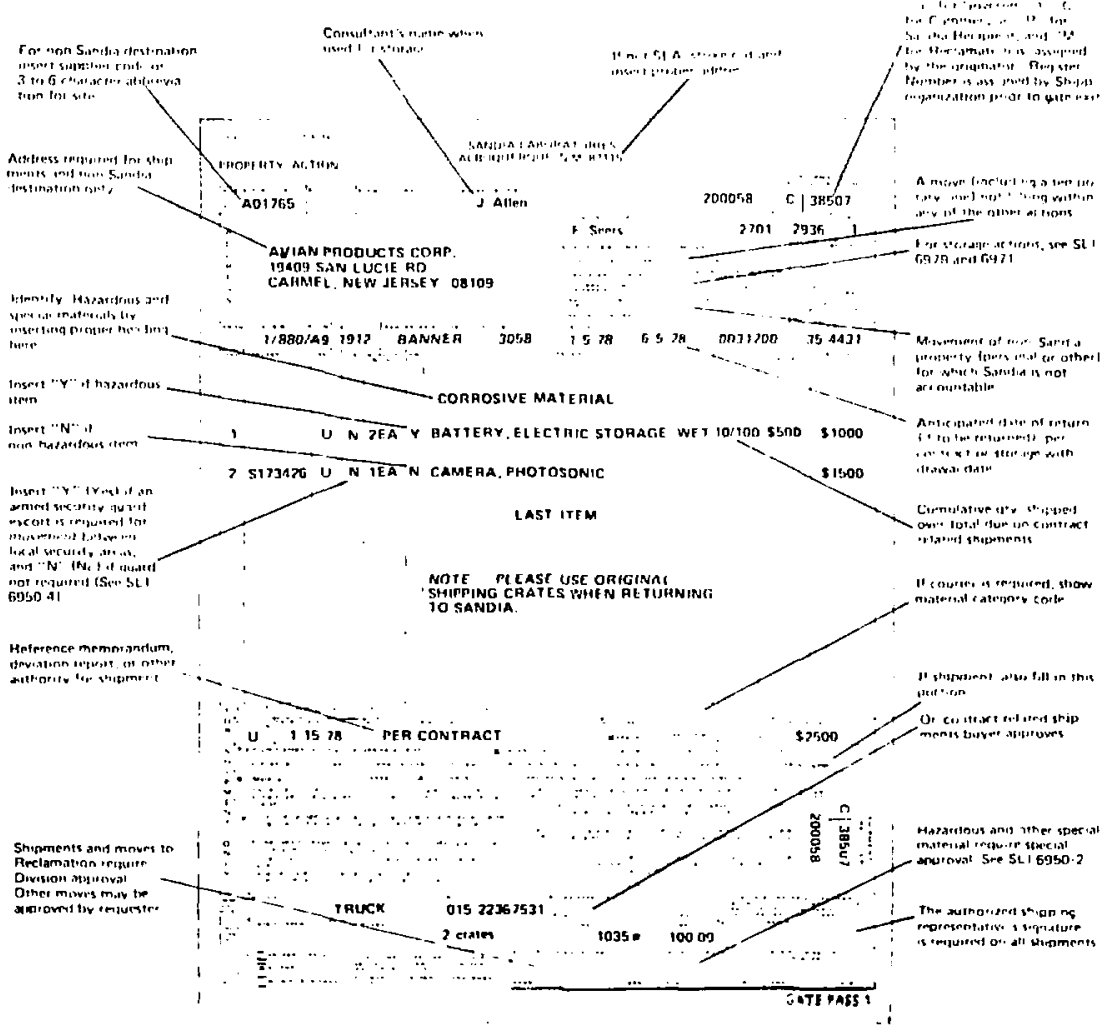


This page intentionaly le lt blank.

$10-35$ 
Form SA 6550-EA --- Information for Hazardous Material Shipments

Purpose: $\quad$ To accompany shipper (Form SF 6951-A) for shipment of radioactive and nuclear materials.

Prepared by: Organization requesting shipment.

Submitted to: Nuclear and Explosives Materials Control Section.

Line Instructions:

$$
\begin{aligned}
& \text { Consultant-org.-Phone: Employce in the requesting organization } \\
& \text { responsible for shipment. }
\end{aligned}
$$


i.xhitsit 12.

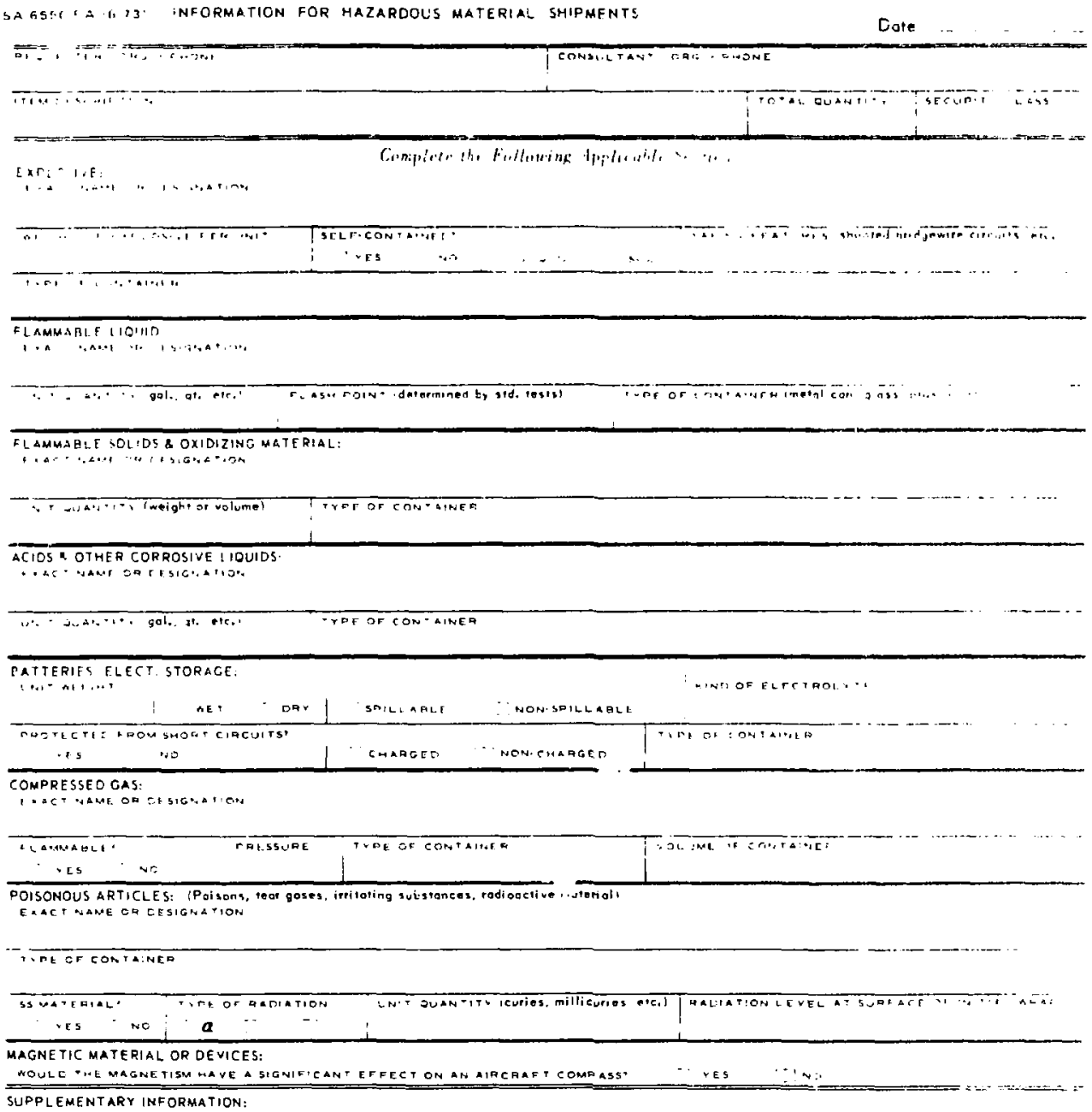




\section{Form RF-43940 -- Authorization to Ship SS or Non-SS Material}

Purpose: To ship materials to Rocky Flats.

Prepared by: Organization requesting shipment.

Submitted to: Nuclear Materialo Representative, Safeguards and Technical Security Division.

Line Instructions:

Station: Contractor name.

RIS: Reference identification symbol of contractor.

Signature of Authorized Representative: To be signed by the Nuclear Materials Representative Safeguards and Technica. Security Division. 


\section{Exiniuit is.}

\section{CLASSIFICATION}

ROCKY FLATS PLANT

GOLDEN, COLOAADO

\section{AUTHORIZATION TO SHIP SS OR NON-SS MATERIAL}

DATE

No.

SHIPPER

SIATION
ADORESS

REOUESTEO SHIPPING DATE

SIGNATURE OF AUTHORIZED REPRESENTATIVE

GENER $\cong L$ MATERIAL DESCAIPTION

SS MATERIAL ICMEMICAL ELSMENT\}

GROSS OUANTITY

PHYSICAL DESCRIPTION

CHFMICAL DESCAIPTION

PRINCIPAL IMPUAITIFS

MATERIAL ORIGINATION (PLEASE CiHECK)

$\square_{\text {LASL: }} \square_{\text {LLL: }} \square^{\text {Sh: }}$

ARHCO: $\square$ BNWL:

OTHER

\section{MATEAIAL HISTORY}

ARE TME RE ANY KNOWN HAZARUS CONNECTEO WITH THE HANDLING OF THE MATERIAL' (YES OR NO

IF VES, DESCRIBE IN DETAIL ON A SEPARAT: SHEET.

WAS THE MATERIAL GEEN EXPOSED TO AN! RAOIONUCLIDES, SUCH AS FISSION PAODUCIS, STHER ACTINIOES,

TRITIUM, ETC? IYES OR NDI

IF YES. OESCAIBE IN DETAIL ON A SEFGAAT.. SHSET THE CONDITIONS IN WHICH THE MIATERIAL WASEXPOSED INCLUDE CONCENTRATIONS OE CONTAMINANTS AND METHODS OF ANALYSIS.

HAS THE MATERIAL COME IN CONTACT WITH ANY HAZAROOUS MATERIAL OR UNDERGONE UNUSUAL PROCESSING OR TESTS: IYES OR NOI

IF YES. DESCRIBE IN DETAIL ON A SEPAG ATE SHEET THE HAZARDOUS MATERIAL RROCESSING OR TESTS DETAIL RADIATION OR CONTAMINANT LEVELS

WHAT IS THE FORM OF THE MATERIAL?

SIG:IATURE AND PHCME NUMBEA OF SHIPPERS CONTACT

TEGARDING CONTAMINANT OR PAOIATION LEVELS

SIGNATUHE

METHOD OF PACKAGING

OIITSIDE CONTAINER TYPE

APPPOX, NO

INSIDE CONTAINER TYPE

APPROX NO

OTRER CONTAINEA INFORMATION

SPECIAL PAECAUTIONS TO BE ODSER̃VIO WHEN OPENING THE CONTAINERISI

\section{RF RECEIVING APPROVAL}

REVIEWED FOR PHOCESS COMPATHORLITY

AUTHORIZED TECHNICAL REPIXESENTATIVE

RE VIEWED FOR MEALTH, SAFETY E ENVIRONMENT

APPROVED FCIT SHIPMENT ON

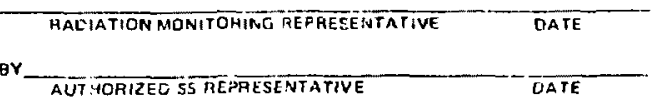




\section{Form --- Request for Foreign Contract Number}

Purpose: To ship materials to a non-U.S. Location.

Prepared by: Organization requesting shipment.

Submitted to: Union Carbide Corporation CSD/ORGDP Nuclear Materials Control

Mail stop 19

P.O. Box P

Oak Ridge, Tennessee 37830

Line Instructions:

Signed: Supervisor of organization requesting shipment. 
Subject:

Qate Prepared:

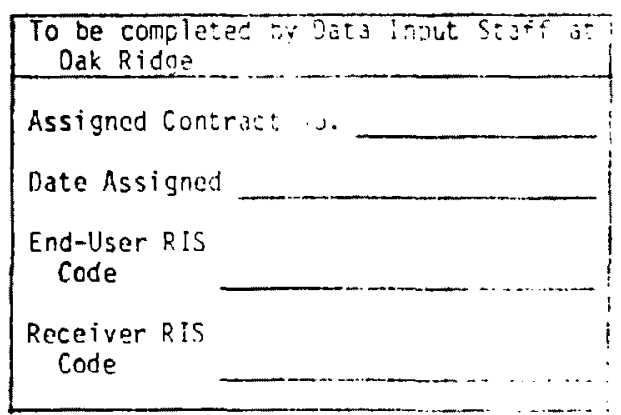

To: Union Carbide Corporation CSD/ORGDP Site

Nuclear Materials Contro:

Mail stop 19

P. O. Box $P$

Oak Ridge, Tennessee 37930

From:

1. Name and Address of Rec iver of Material:

2. Type of Transaction (Sàle, Lease, etc.):

3. End User (if different 'rom Receiver):

4. End-Use Statement Code - (Refer to attached : nd Purpose Code Tabic;

Exhibit $C$ 
5. Material Type(s) and Description (Refer to attached Table): Material Code Element Wt. Wt.s Isotope Isotope Wt.

6. Authorization for shipment (Check one):

_ Export License (NRC)

U.S. Department of Commerce License

DOE - Approved Shipper's Export Declaration

__ Method of Export Approval Unknown at this Time

__ General Licensed Material - No Export License or DOE Approval Required.

7. Has contract already been executed? Yes __ No If yes, on what date?

Signed:

Date: 
Material Type Codes and Reporiting Weight Required

\begin{tabular}{|c|c|c|c|c|}
\hline Material & Code & Element wt. & Wt.: I sotope & I sotope Wt. \\
\hline Depleted U & 10 & Total U & $U-235$ & $U-235$ \\
\hline Enriched U & 20 & Total U & $U-235$ & $U-235$ \\
\hline Plut onium-242 & 40 & Total Pu & $P u-242$ & $P_{u-242}$ \\
\hline Americium-241 & 44 & Total Am & - & Am-241 \\
\hline Americium-243 & 45 & Total Am & - & $A m-243$ \\
\hline Curium & 46 & Total $\mathrm{cm}$ & - & $\mathrm{cm}-245$ \\
\hline Berkel ium & 47 & - & - & $B k-249$ \\
\hline Californium & 48 & Total Cf & - & $C f-252$ \\
\hline Plutonium & 50 & Total Pu & $P u-240$ & $\begin{array}{l}P u-239+ \\
P u-241\end{array}$ \\
\hline Enriched Li & 60 & Total Li & $L i^{6}$ & $L i^{6}$ \\
\hline Uranium-233 & 70 & Total U & $\mathrm{V}-232(\mathrm{ppm})$ & $U-233$ \\
\hline Normal U & 81 & Total U & - & - \\
\hline Neptunium-237 & 82 & Total Np & - & - \\
\hline Plut onium-238 & 83 & Total Pu & $P u-238$ & Pu-238 \\
\hline Deuterium & 86 & $\mathrm{O}_{2} \mathrm{O}$ & - & $\mathrm{O}_{2}$ \\
\hline Tritium & 87 & Total Tritium & - & - \\
\hline Thorium & 88 & Total Th & - & - \\
\hline$U$ in Cascade & 89 & Total U & $U-235$ & $U-235$ \\
\hline
\end{tabular}


*END PURPOSE CODE TABLE

Code

00

10

20

30

40

50

60
Description

Reactor Operations
01 Use as fuel
02 Use as coolant
03 Use in fission counters
Critical facilities
11 Assembly loading of critical and
subrriticals
12 Use in subcritical facility
13 Use in critical facility
Manufacturing
21 Special interial production
22 General manufacturing (non-fuel)
23 Fission counters
24 Materials blending
25 Process develowment
26 Product evaluation

Fuel

31 Fuel test, LWR

32 Fuel test, EBR

33 Fuel test, other

34 Fuel examination

35 Fuel fabrication

36 Fuel enrichment

37 Conversion

38 Reprocessing

Instrumentation

41 For instrument material

42 Instrument testing

43 Instrument devices

Medical

51 Pacemaker parts

52 other uses

Research \& Development

61 Basic research

62 Medical research

63 Enrichiment research

64 Reactor operations research

"Use detail code if possible. Otherwise, use general coce such as 10,20, 30, etc. 
65 Fuel research

66 Instrument research

67 Conversion research

68 Reprocessing research

69 Fuel fabrication research

71 General nuclear experiments

72 Physical measurements

73 Irradiation experiments

74 Post irradiation examination

75 Material testing (non-fuel)

76 EBR program development

77 LWR program development

78 Reference material

79 Measurement method evaluation material

80

Material Transfer

81 Return of spave test material

82 Return of previously leased material

83 for later resale/lease

84 Safeguards inspection sample

90

Others

91 Disposal (final waste)

92 Storage (temporary) 


\section{Form NRC-7 --- Application for Licensp :o Export Nuclear Material and Equipment}

Purpose: $\quad$ To obtain license for shipment of materials to a
non-U.S. location in conjunction with a NRC agreement.

Prepared by: Organization requesting shipment.

Submitted to: Assistant Director for Export/Import and

International Safeguards

U.S. Nuclear Regulatory Commission

Washington, D.C. 20555

Line Instructions:

Applicant's reference: NRC agreement name/number.

Authorized Official: Department Manager of organization applying for 1 icense. 
Exhibit 15

Foria NAC-7

$(7-70)$

Ie CFR 110

US. Muclean ALOULATONY conmmingm

APPLICATION FOA LICENSE TO EXMORT NUCLEAR

MATERIAL AND EQUIPMENT (Ses Intmucrions on Reverol

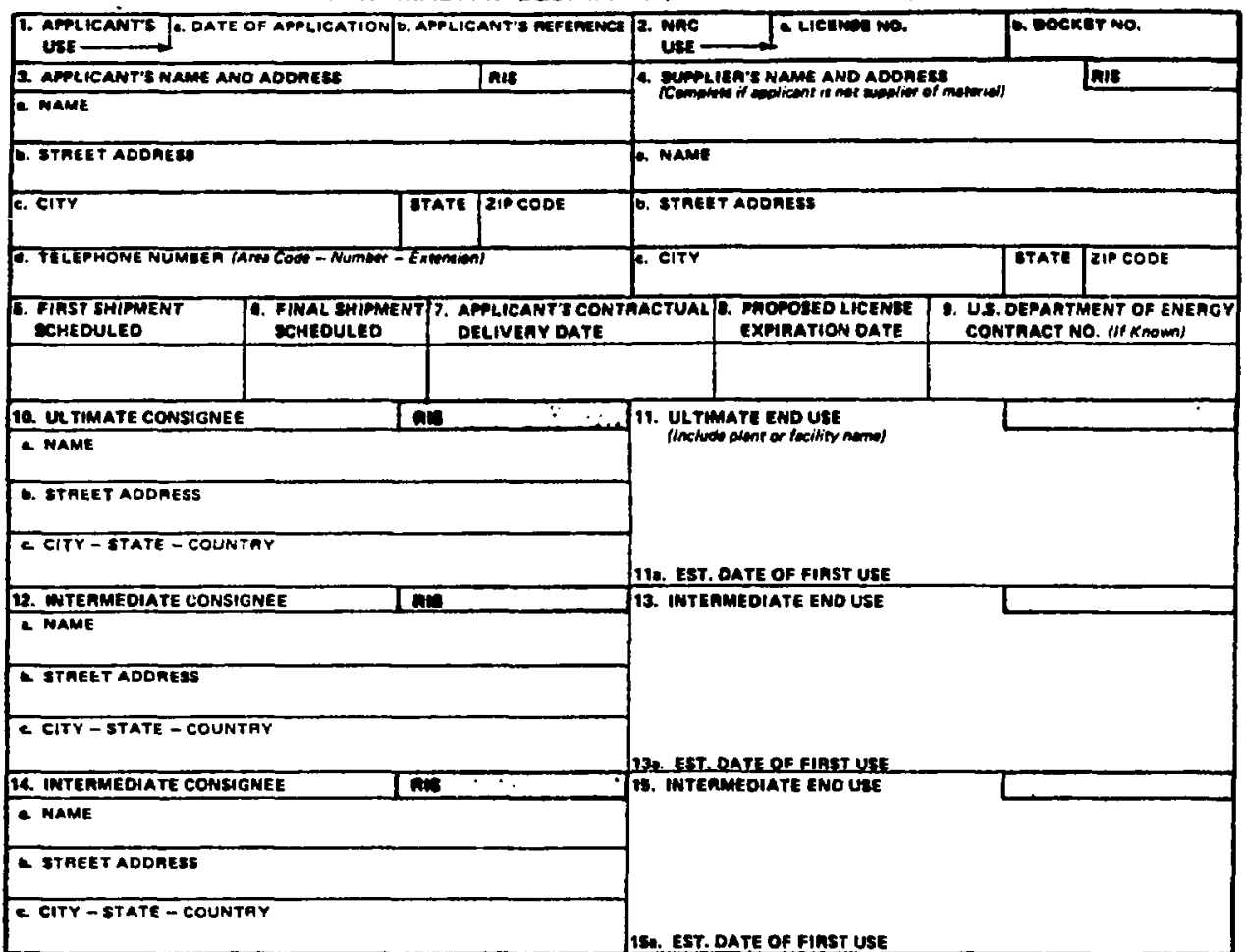

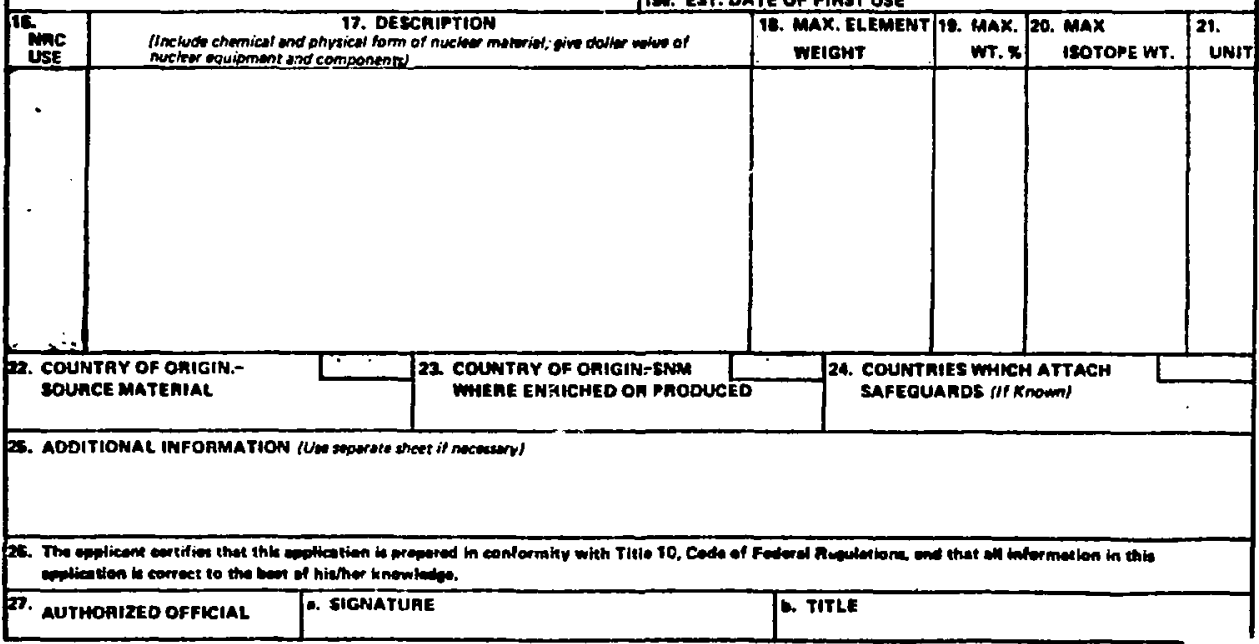




\section{INSTRUCTIONS FOR PREPARATION OF APPLICATION FOR LICENSE TO EXPOAT NUCLEAR MATEHIAL AND EOUIPMENT FORM INAC-7)}

One stgned, origunal of Form NRC-7 must be submitted by the spplicunt to the Assistant Ditector for Export/import and International Saiguards, U.S. Nuclear Regulatory Commission, Washington, D. C., 20555, of delivates in petson to the Commission's Offices at 7735 Old Georgetown Road, Bethesda, Maryland or 17i7 H Street. N. W. Warhington, D. C. All items on this form should be completed, to the extent the intormation is availabie al the time the application is submitted.

An upplicons for on export license must make full disclosure of all recipients of the proposed expon so that a decision on the apnlieazion may be made with full knowledige of all rulevan! tacts. Tha name(s) and address(es) of ine plant, faeiliy, firm or location whete the material may be handled, stored, converted or tabrieated and where ine material uitimately will ba used. together with precise facts concerning the use that will be made of the items to be exported by each iniermediste and uitimate consignue must be stated. The materisis of equipment to be exported inust be fully and accurately described in dotuil. II more space is needed, attach an additionsl shcet of paper.

The following is excerpted from the Nuclear Fegulatory Commission regulations prescribing procedus es and stendards for the expon and import of nuclear equipment and nucleaf inaterial. For the completc codification of NRC's export and import regulations applicanis for licenses should iefer to Part 110 of Title 10 , Chapter 1, Code of Federal Regulation.

Subaert D-Appltations for Specific Licenum

5 11030 Futing a litense opplicetion.

(a) A licmse anolicalion shall be liled with the Assistumi Oirector for Exportilmport and Internalional Su! inuatd, U S. Nucles Aeguflos, Commisson, Washington. DC. 20555 or detivered in netson to the Coinmusion't offict's 31 1717 it Strees N.W. Washingion, D.C. or 7735 Old Georgatown Rowd, Betheuds. Md

(b) Exerot for moduction of villization tacilities. export ticense spedication should be fuled on loym NRC.?

(c) An appincetion to: Herense to expons. groduction of utilization tacility or to impon becouction of utilization facility or to import nucledr rawining

(a) An ingizcan mdy fite a camolidand licenie application involving two or more pronsed exports of similat ravipment of material destined for thi same country, pro-ded all the ewiots will be made within? veds of other time peliod as approwed by the Commisston and under restonubly ymita circumstances.

(e) II - im imoort license epplication involves

(el If an import license application involves
rawipment a material which in intended for rawpment al material which in intended for subkrovent expost, the apticant may simut: ianeutiv apoly lot the apploptiate empont not imply acprousl of esubsequent onpost.

(1) Intormation contaned in previous apalication may be ineorporated by relerence.

E \$10.31 Generat recuiraments fot un mport license epplication.

Each application tor on enport incenes shati מate.

(a) Name and U.5 codrest af apolicant; (b) Name and woders of wpplier of equpmient of materist, at aiflerent from the eppli. cant:

(c) Neme and addim of ultimble consisnee(b):

(a) Nome and edan of miermadite consogne(1):

(e) Date of proposed lint shipenent:

il Date of propoud completion of find thipment:

(g) Contractual delivery doles, il enoblinhad:

(n) Procosed empitution onte al etport liconie; ond
(1) End-use of maicrial or equinmrni by all consigner, intpim moldir and uttimate, with sut. ticisent detal to onsimit secutale exolustion of

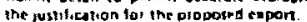

f $t 1032$ Additional exuuirements for onuctest equipiment expon licenso application.

An apuication for a ficemse ta exnort nuclea cquiliment shall state the lalliswing. in addition 10 ine apreral infoim ation snecified in \$110 31

(a) Grtiaral destelintion of the rauinment.

(b) For nuelest eaciois, the detign power lexet in the mal ot electicti wats.

(c) Name of inswitibtion, tl knom, in which (c) Name of inswatiofion.
the pquipmenl is to be used

(d) Loction whrte ine equibment is to be wred,

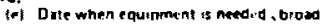
(I) Total dollat value of all items to be ex. ported under the reqursied license. and

(g) A list of the items proposed to be exported Such list reed oniy identify the items by the calegories listed in pardgraphb a. imoough - Df eppendin $A$

\$110.33 Additions rowuirsments far a meloe materish empon liemse upplication.

Each application for a license to expoz nu ele de matirial shall sidte the following, in eadi ion to the geneial irquinement in 5110.31 .

(a) The apolicable contiaci numbri. known, of eny matetial supplied under a Denartment of Energy enichment leare, or sale constacis:

Ibl Where matelials ate imtended to wise in producion or vili:=tion qacility, emtimated pate of first ust, by ultimute of inierinediale date of first

(c) Chemiel and onvsical form, metuotim (or entiched uranism, the weaght anercentag: of for entiched uranim, the weight netcenteg: of isolopic entichmrnt, and. Tol Nutomum, the Purzal content:

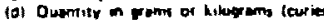
for byoroduct materiall of 111 the malertel in

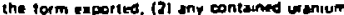
of olutumum (3) the contaned U-235 in enerehed uronium; ind

(a) II know, the counitry of or ain of (t) If know, the counity of on ain of cource and gecial nucira matetiaf inciuding wa produced.
\$110.34 Requiremunts for an imporn lieame opplication.

Eath applicatoan for an impoil licmse shat thate

(a) Name and U S eddiess of appticant

(b) Country and insiallation from which the mucleat equament on material is being imported ic) Name and wdiess of suppliet of the nucleat cquioment of miterial:

[d) Destination and ultunute use of the nucleat knuipment or material:

(e) Date ol proposed fist shupmen:

if) Date of proposed completion of fins shipment.

(a) Cremical and phrsieal fosm of nueles material, including. lor entiched uramium, the we nght percentuge of enrichment. and lor plutonium, the sum of the netcentaget of Pu-239 content and Pu.24t content.

(h) Ouantity in grams of hilograms of: (1) the nuclear material in the form imporied, (2) any contained utanium or plutorium, and (3) the contaned U.235 in enrichned utenism.

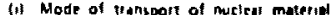
and asckuge dientilicetton lineiuding IAEA Certilicete of Competem Authosty numberl: Certılice

(i) II known. the countey of origin of muciem matrisal including the counter whete any specul nueles muteris was oroduced.

$\$ 110.35$ Firther Information to a dieme pricent.

b) Thr Commistion may requite further information teom the ficense opplicant it netesseiy to complete ipview of the soplestion.

(b) Each applieant inall file an amandmant

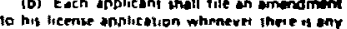

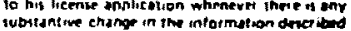
in his apoticstion.

5110.35 Withdrewel of a liesen andientien.

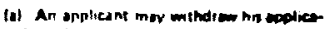
togn of any time.

(b) An wonicant ghall withdrat on epolica-

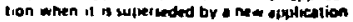
or when he no longes iniends to we his liceme il waved.

|c| The whindawat of a licente epplacetion doet not outhoris? the iemove of ony NhC recerd from Commision files. 
inis pago intentionally left blank.

$10-49$ 
Form 7525-V -..- Shipper's Export Declaration

Purpose: $\quad$ T) obtain authorization for shipment of materials to a non-U.S. location.

Prepared by: Traffic Management Division.

Submitted to: D. L. Krenz, Director

Shecial Programs Division

DIE/ALO

$10-50$ 
Ixhibit 16

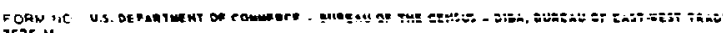
SHIPPER'S EXPORT DECLARATION OF SHIPMENTS FROM THE UNITED STATES

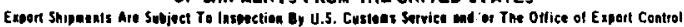
READ CAREF ULLY THE INSTRUCTIONS ON BACK TO AVOID DELAY AT SHIPPING POINT

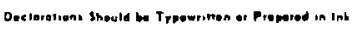

DO NOT USE THIS AREA

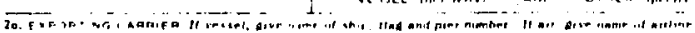

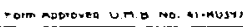

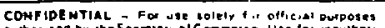

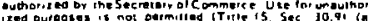

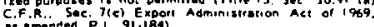
Authentication (When iequired

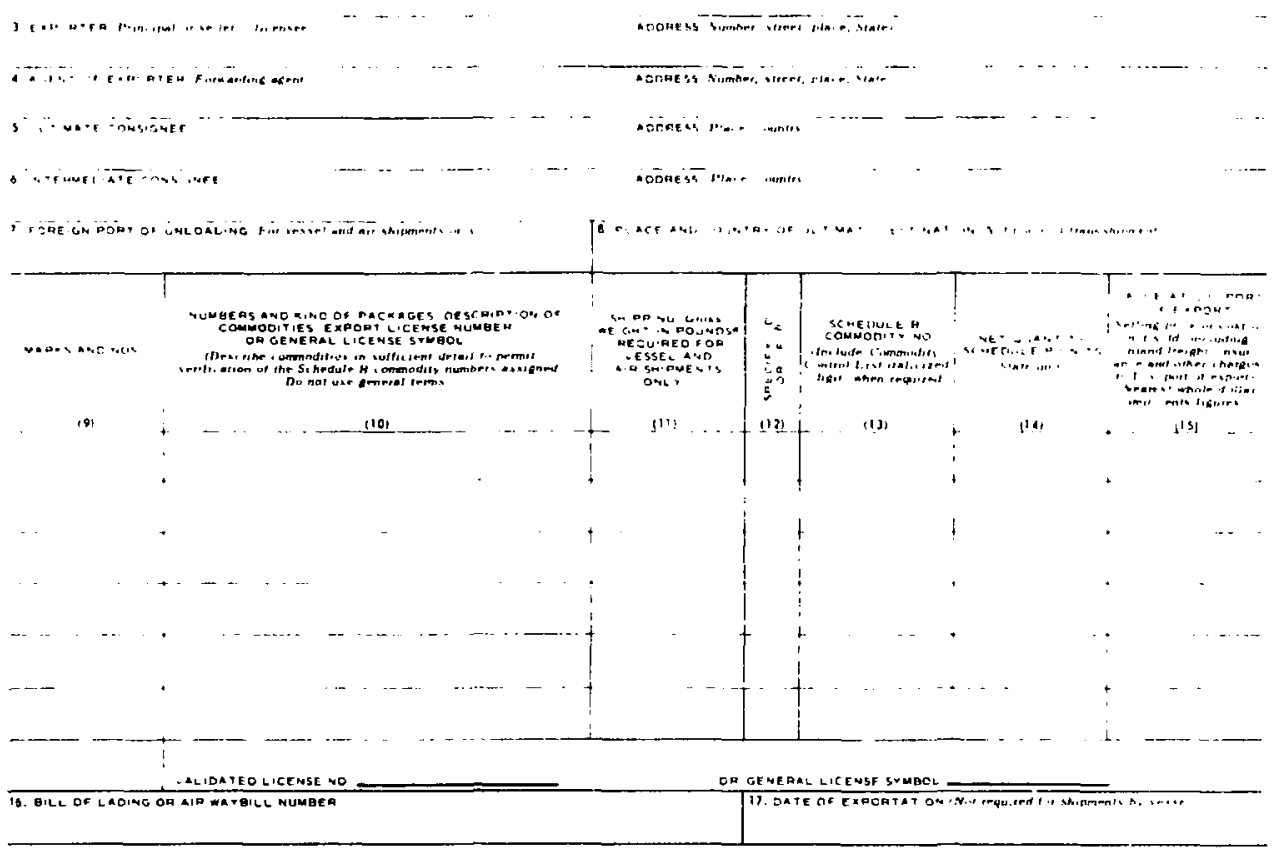

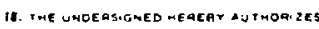

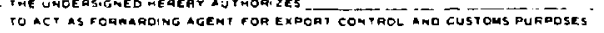

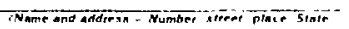

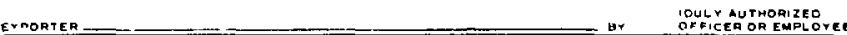

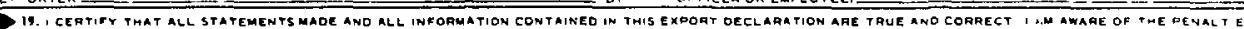

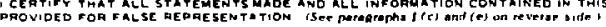

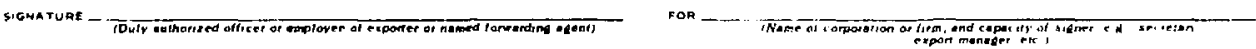

ADAESs

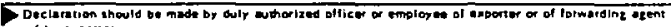

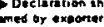

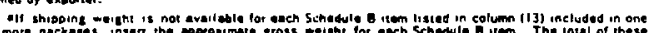

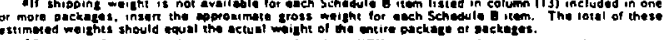

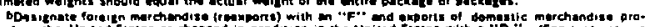

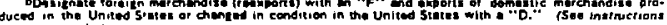
ducruaratesides 


\title{
INSTRUCTIONS FOR THE USE OF THE SHIPPER'S EXPORT DECLARATION
}

\author{
IFOLLON CAREF ULLT TO AVOID DELAY AT SHIPPING, POINTI
}

\section{GENERAL PROVISIONS OF LAW AND REgULATIONS}

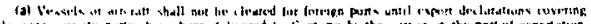

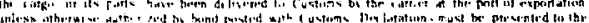

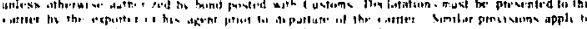

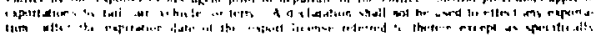
inthensing

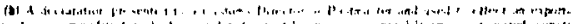

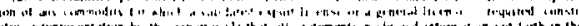

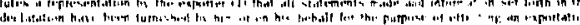

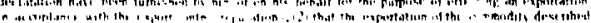

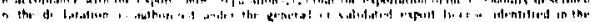

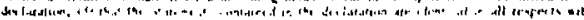

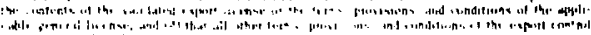

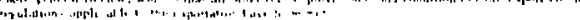

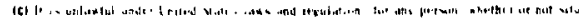

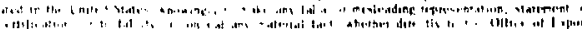

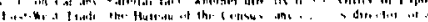

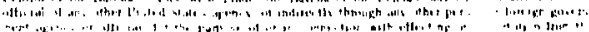

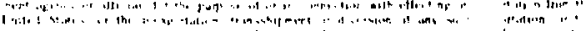

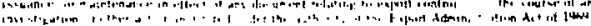

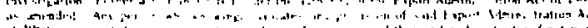

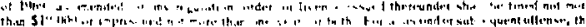

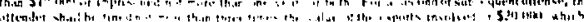
?

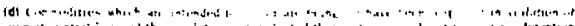

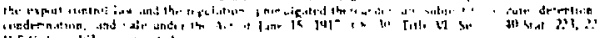

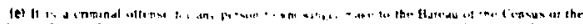

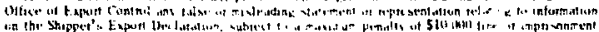

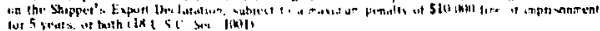

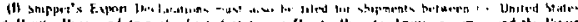

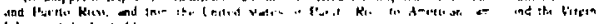

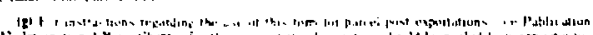

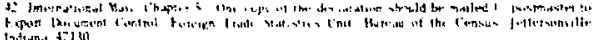

11. SH:PPER'S EXPORT DECLARATIONS (Commeite Fom 7525-V)

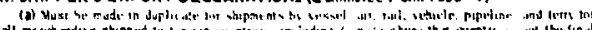

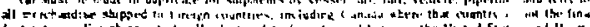

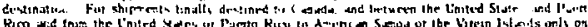

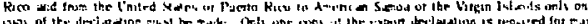

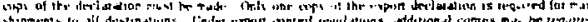

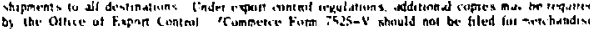

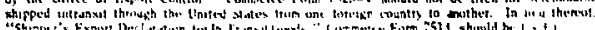

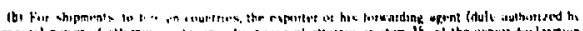

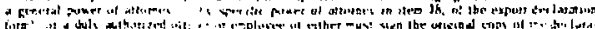

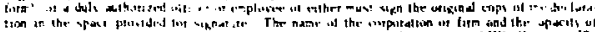

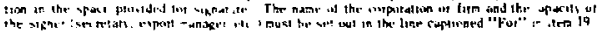

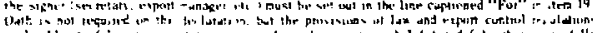

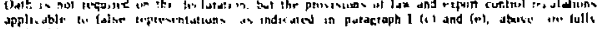
aplicuble

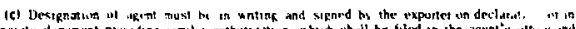

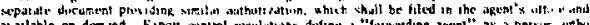

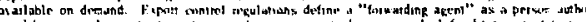

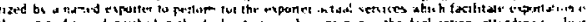

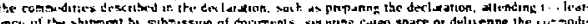

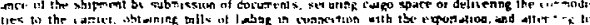

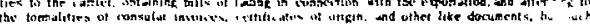

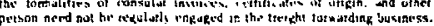

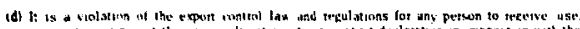

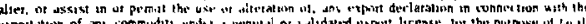

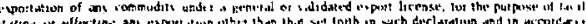

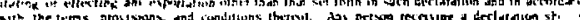

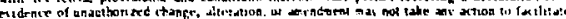

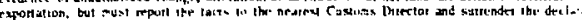
rypotiafton, but sust

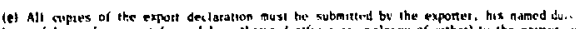

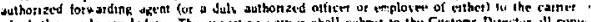

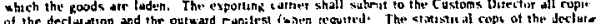

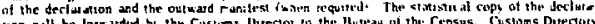

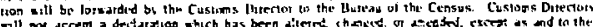

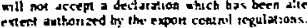

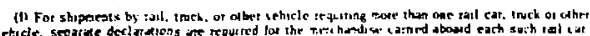
iruric of other irhicie.

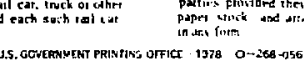

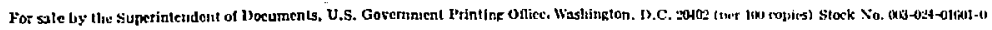

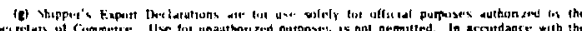

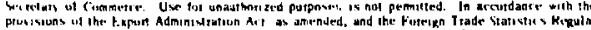

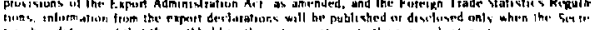

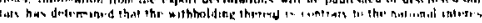

\section{EXPLANATION OF TERMS}

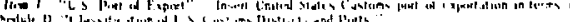

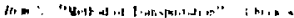

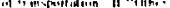

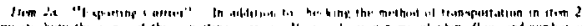

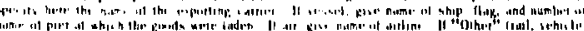

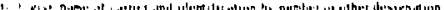

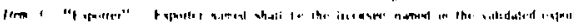

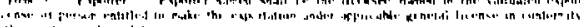

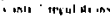

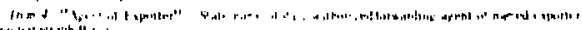

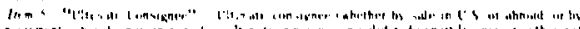

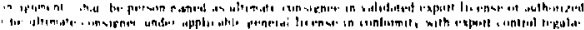
1.1 li..

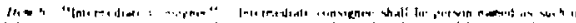

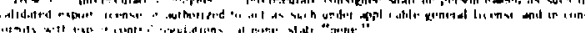

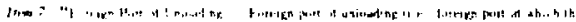

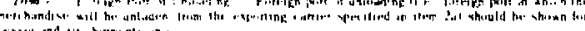

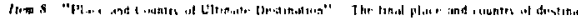

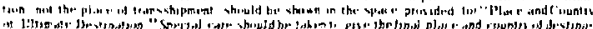

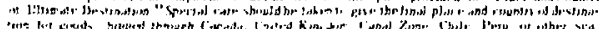

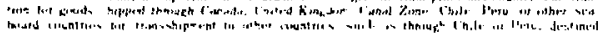

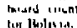

\section{SPECIFIC IHSTRUCTIOAS}

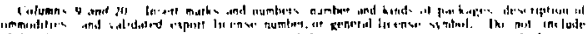
?

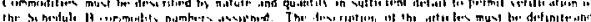

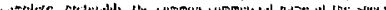

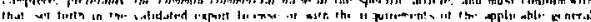

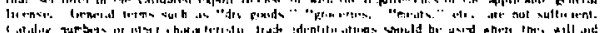

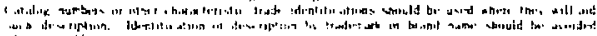
- he we penvibl.

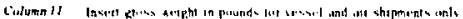

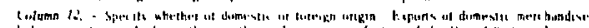

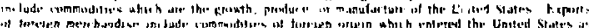

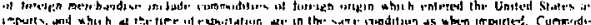

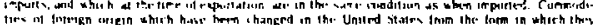

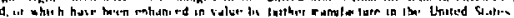

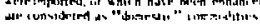

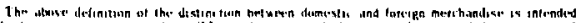

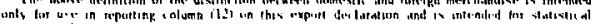
purposies ink

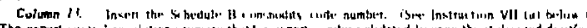

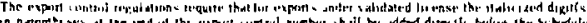
in sis.

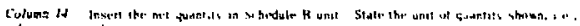

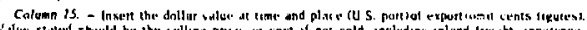

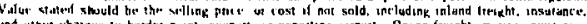

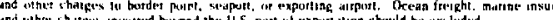

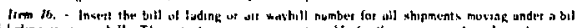

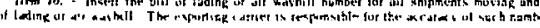

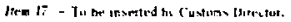

V. SIGNATURES

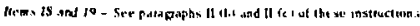

VI. FOREIGN TRADE STATISTICS REGULATIONS - EXPORT CONTROL RECULATIONS

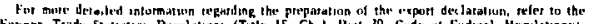

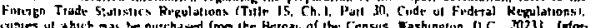

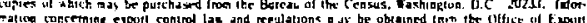

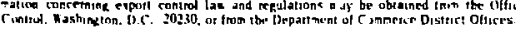

\section{SCHEDULE B AND BLANXS}

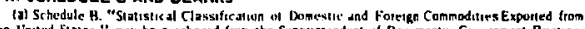

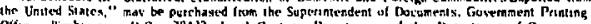

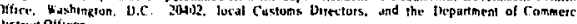

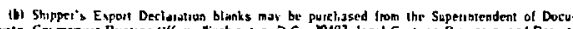

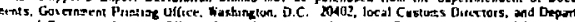

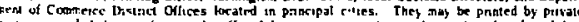

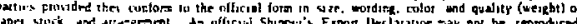

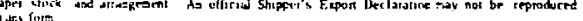


This page intentionally left blank. 
Form SA 6476-ME --- Modification/Expenditure of Nuclear Materials

\author{
Purpose: To obtain prior authorization for modification or \\ expenditure and to provide notice of the actual \\ modification or expenditure. \\ Prepared by: Using Organizations. \\ Submitted to: Nuclear Materials Manager in the Saieguards \\ and Technical Security Division.
}


$\hat{A}$ All modification/expenditure of nuclear materials must have prior approval of DOE/ALO.

1. A yearly authorization to modify/expend nuclear material is obtained in September for the next fiscal year.

2. All nuclear material to be modified/expended that is not included in your yearly authoriza. tion must have prior approval by completing section I and returning this form to Org. 3434 (a copy of this form will be returned to you after approval).

B. Section 11 must be completed and returned to Org. 3434 atter each modification/expenditure of nuclear material (this section is used to account for, adjust and/or dispose of scrap material).

Ref: Operating procedures for custodians and users of radioactive and nuclear materials, SAND 771936 , CH. IX, Sect. 11.

Naine _...

1. REQUEST TO MODIFY/EXPEND NUCLEAR MATERIAL Case No.

Approx. Date for modification/expenditure ... . .

Material to be used

SERIAL NUMBER DESCRIPTION OF MODIFICATION/EXPENDITURE

DOE/ALO Approval

Date

11. NOTICE OF MODIFICATION/EXPENDITURE OF NUCLEAR MATERIAL

Date of modification/expenditure

Material used

SERIAL NUMBER

DESCRIPTION

NO. OF

PIECES

SCRAP QTY. ISO. WT

METHOD QTY. DETERMINED 
Form SA 6476-NG --- Transfer Request

Purpose: To record data received by telephone from custodian's transferring material to another material balance area

Prepared by: Accountability Clerk in the Safeguards and Technical Security Division.

Submitted to: Destroyed following computer input. 
Exhibit 18

Date_........

\section{TRANSFER REQUEST}

Custodian Requesting Transfer:

Phone Ext. .

Transter Document Number:

Date to be Transferred: $/ . .1$

Transfer From MBA:

Transter To MBA:

Type of Transfer I (Internal), S (Storage), B (Burial), M (Machining), R (Shipment):

Special Instructions (Size/Weight requiring Special Equipment/Damaged container or Hazardous Material requiring Health Physics Participation, Etc.):

Serial Numbers of Material to be Transferred:

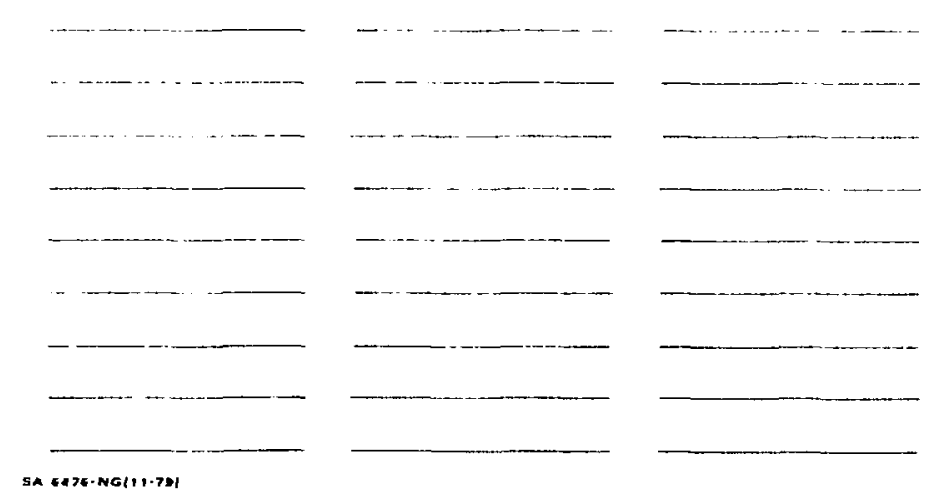

